F A C ULD A D E D E F I L O S O F I A, L E T RAS E C I E N C I S H UMA NAS

De partamentode Filosofia

\title{
O Dialogo di Pittura de Paolo Pino, o Dialogo della Pittura, intitolato L'Aretino de Lodovico Dolce e a reflexão sobre a arte em Veneza no século XVI
}

\section{Rejane Maria Bernal Ventura}

\author{
Orientador: Prof. Dr. Victor Knoll
}


F A C ULD A D E D E F I L O S O F I A, L E T RAS

E C I E N C I S H UMA NAS

De partame ntode Filos ofia

Tese apresentada ao Departamento de

Filosofia da Faculdade de Filosofia, Ciências e Letras da Universidade de São Paulo, sob orientação do Prof. Dr. Victor Knoll, como requisito para obtenção do título de Doutor em Filosofia.

\section{O Dialogo di Pittura de Paolo Pino, o Dialogo della Pittura, intitolato L'Aretino de Lodovico Dolce e a reflexão sobre a arte em Veneza no século XVI}

\section{Rejane Maria Bernal Ventura}


Banca Examinadora 


\section{Resumo:}

Esta pesquisa tem por objetivo investigar alguns aspectos que permitam sistematizar uma teoria da arte na Veneza do século XVI, a partir de dois tratados artísticos: o Dialogo di Pittura, de Paolo Pino (1548) e o Dialogo della Pittura intitolato L'Aretino, de Lodovico Dolce (1557). Para isto, enfoca cinco problemas: o conceito de mimesis; a estrutura dos tratados em sua relação com a Arte Retórica; Pino e Dolce como representantes da doutrina do ut pictura poesis; o ideal de beleza e a disputa pela primazia da cor sobre o desenho.

Palavras-chave: Paolo Pino, Lodovico Dolce, pintura veneziana, mimesis, Arte Retórica, ut pictura poesis, ideal de beleza. 


\begin{abstract}
:
This research deals with some aspects that enable to systematize an artistic theory in Venice from sixteenth century, from two artistic treatises: Paolo Pino's Dialogo di Pittura (1548) and Lodovico Dolce's Dialogo della Pittura intitolato L'Aretino (1557). In order to get over this objective we will discuss five problems: mimesis' notion; the treatises structure in your relation with Rhetoric; Pino and Dolce as ut pictura poesis doctrine members; the ideal of beauty and the debate for the primacy of colour over design.
\end{abstract}

Key words: Paolo Pino, Lodovico Dolce, venetian painting, mimesis, Rhetoric, ut pictura poesis, ideal of beauty. 


\section{Agradecimentos}

Agradeço profundamente ao Prof. Dr. Victor Knoll, pela oportunidade da orientação e pelas agudas sugestões, pelo diálogo aberto, o apoio e a extrema compreensão diante de minhas inquietações ao longo de todo trabalho.

Expresso igualmente minha gratidão ao Departamento de Filosofia, que me acolheu como um de seus estudantes.

À CAPES, pela bolsa de estudos, sem a qual esta pesquisa não poderia ter sido realizada.

E, por fim, meu agradecimento aos membros banca examinadora, pela disponibilidade de leitura deste material. 


\section{SUMÁRIO}

$\begin{array}{ll}\text { Introdução } & 08\end{array}$

$\begin{array}{ll}\text { Capítulo I - O conceito de mimesis } & 21\end{array}$

Capítulo II - Os Tratados em sua relação com a Arte Retórica 48

Capítulo III - Pino e Dolce partidários da doutrina do ut pictura poesis 62

$\begin{array}{ll}\text { Capítulo IV - O ideal de beleza nos Tratados } & 97\end{array}$

Capítulo V - A disputa pela primazia da cor sobre o desenho 125

$\begin{array}{lr}\text { Considerações finais } & 145\end{array}$

$\begin{array}{ll}\text { Referências Bibliográficas } & 147\end{array}$ 


\section{Introdução}

O objetivo desta pesquisa é investigar alguns aspectos que permitam sistematizar uma teoria da arte na Veneza da primeira metade do século XVI. Para tanto, tomaremos por objeto de estudo dois tratados artísticos do período: o Dialogo di Pittura, de Paolo Pino (1548) e o Dialogo della Pittura intitolato l'Aretino, de Lodovico Dolce (1557).

A pesquisa pretende responder a três questões que consideramos relevantes para o estudo da arte do século XVI: 1) É possível delinear uma teoria artística peculiar à pintura veneziana na primeira metade do século XVI? 2) Há dissonâncias entre a teoria de arte veneziana e a teoria desenvolvida na região Tosco-romana? 3) E quais os conceitos filosóficos inerentes a essas duas teorias?

As referidas questões serão respondidas a partir da investigação de cinco problemáticas que consideramos centrais na discussão das temáticas presentes nos dois tratados. São elas: a) o conceito de mimesis; b) os Tratados em sua relação com a Arte Retórica; c) Pino e Dolce partidários da doutrina do Ut pictura poesis; d) o ideal de beleza nos tratados; e) a disputa pela preponderância da cor sobre o desenho.

A fim de atingirmos esse propósito, levaremos em consideração os argumentos constantes nos textos, as categorias filosóficas, literárias e históricas trabalhadas pelos autores, as fontes com as quais dialogam e alguns pressupostos pertencentes aos pensamentos de Platão e Aristóteles, de modo que este caminho nos possibilite apontar a especificidade da concepção artística destes autores, que por sua vez, reflitam as problemáticas discutidas por artífices e humanistas do período.

A teoria da arte italiana constituiu-se enquanto tal somente a partir do século $\mathrm{XV}$, com os escritos de Leon Battista Alberti e Leonardo da Vinci. No período que os antecedeu, as considerações sobre as artes figurativas foram registradas em forma de manuais preceptivos, singulares às oficinas dos artífices, e em comentários que ensaiavam dar conta de uma teoria da arte. Alberti e Leonardo estabeleceram a base científica de legitimação para o fazer artístico, em especial a pintura. Aos teóricos posteriores coube rediscutir suas premissas sob novos pontos de vista. Entre eles encontram-se os dois tratadistas objeto desta pesquisa, Paolo Pino e Lodovico Dolce. A escolha de tais autores deveu-se ao fato de 
serem os seus tratados os primeiros e mais relevantes escritos sobre a pintura produzidos em solo vêneto na primeira metade do século XVI. As discussões por eles apontadas os colocam por um lado, em estreito diálogo com um dos principais teóricos toscanos, no caso Alberti, e por outro, em papel divergente, onde apontam peculiaridades no modo de conceber a pintura veneziana em relação a tosco-romana. São estas singularidades que, ao nosso ver, tornarão possíveis delinear uma teoria artística própria à região setentrional italiana.

Nesse sentido, seria conveniente introduzir uma pequena contextualização dos dois tratados, inserindo-os numa linha de continuidade com os escritos sobre arte anteriores a eles.

\section{Os tratados em seu contexto histórico:}

Segundo Julius Schlosser Magnino, em La Letteratura Artistica, tanto quanto a maior parte das manifestações culturais da Europa, a literatura que se refere às artes figurativas encontrou igualmente suas raízes no período Helênico. ${ }^{1}$ No entanto, pouco deste material sobreviveu até nós. Os únicos testemunhos que restaram daquelas antigas ciências ficaram, primeiro lugar, a cargo da volumosa enciclopédia de Plínio, o Velho (século I d.C), a Naturalis Historiae, composta de 37 livros que discutem os mais diversos saberes: cosmologia e geografia, antropologia e zoologia, botânica, medicina e farmacologia e o livro 35, dedicado à mineralogia e história da arte. Este último ocupa-se de minérios como ouro, prata, bronze, cobre, ferro e chumbo, e de cores minerais, como as pedras, em particular o mármore e gemas preciosas. Plínio discorre ainda sobre as realizações dos maiores artífices da Antiguidade Grega e registra não só os avanços técnicos obtidos por eles, como também elenca uma bibliografia com fontes utilizadas bem como recordações de infinitas riquezas que acabaram por se dispersar para sempre. Os modelos de Plínio foram Xenócrates e Praxíteles, cujos escritos sobre argumentos técnicos eram acrescidos de conclusões históricas e teóricas decorridas de uma prática artística. ${ }^{2}$

\footnotetext{
${ }^{1}$ SCHLOSSER MAGNINO, Julius, La Letteratura Artistica - Manuale delle fonti della storia dell'arte moderna. Florença. "La Nuova Italia” Editrice. 1956, p. 9

${ }^{2}$ Idem, ibidem, p. 9 e 10.
} 
O segundo principal testemunho resultou do empenho de Marco Vitrúvio Polião (século I a.C.), com sua compilação de antigos conhecimentos sobre arquitetura, descritos nos dez capítulos de sua obra De Architectura, ${ }^{3}$ a qual recebeu maior valor e destaque quando dos estudos, comentários e traduções efetuados pelos teóricos dos séculos XV e XVI.

É contudo na Idade Média que se inicia o recolhimento e a reunião dos métodos de oficinas, na tentativa de recuperar os ensinamentos perdidos. E esta torna-se a única literatura artística em sentido restrito por recomeçar das ruínas em que se encontrava o mundo antigo. ${ }^{4}$

No que diz respeito à arte da pintura, a historiografia registra que um dos primeiros tratados a mencioná-la, foi o De coloribus et artibus Romanorum, de um autor denominado Heráclio, provavelmente do século X, no qual ele discorre sobre a propriedade das pedras, miniaturas, técnicas de vidro e cerâmica. ${ }^{5}$

Outro texto de igual relevância é o De Diversis Artibus, do monge Teófilo, composto provavelmente entre os séculos XII e XIII. Escrito de caráter enciclopédico sobre a técnica da arte medieval cristã que se desenvolvia nos conventos, constituía-se em um receituário de técnicas sobre iluminuras, pintura mural, fabricação e pintura de vitrais, trabalhos em metais (especialmente relicários), peças em marfim, pedras preciosas e gemas, caracterizando-se por conter elementos da arte bizantina. ${ }^{\mathbf{6}}$

De acordo com Schlosser, a conclusão da literatura artística medieval representada pela última herança literária do grande desenvolvimento artístico da Toscana no século XIV, se dá com o tratado de Cennino Cennini (séculos XIV-XV), Il Libro dell'arte, escrito por volta de $1398 .^{7}$ Trata-se de um manual sobre o trabalho de oficina, em que ele discorre sobre a produção artística, dando maior ênfase ao aspecto material dos procedimentos. Cennini apresenta técnicas de desenho, como o desenhar a bico-de-pena e a natureza dos pigmentos e cores, ensinando como prepará-los para a pintura. Propõe igualmente o tratamento de papéis e telas, escreve sobre a pintura mural a fresco, a seco, à aguada, a óleo,

\footnotetext{
${ }^{3}$ Idem, ibidem.

${ }^{4}$ Idem, ibidem, p. 25.

${ }^{5}$ Idem, ibidem, p. 26.

${ }^{6}$ Idem, ibidem, p. 30.

${ }^{7}$ Idem, ibidem, p. 91.
} 
à têmpera; discute de modo sucinto a teoria das proporções e perspectiva e ainda o trabalho de arte decorativa em diversos gêneros. Semelhante ao tratado de Teófilo, é um receituário que incorpora, segundo Schlosser, elementos ainda medievais, mesclados a modernos. ${ }^{8}$ Importantíssimo por descrever as problemáticas de ordem material defrontadas pelo artífice em sua oficina de trabalho, todavia, não se reporta à parte intelectual da concepção artística, ou mesmo prescreve teorias. A teorização da arte começará a despontar somente mais tarde.

Um outro tratado relevante que apresenta características mais historiográficas é o $I$ Commentarii, de Lorenzo Ghiberti (1378-1455), cujos manuscritos passam a circular entre o XV e o limiar do XVI. É um registro de caráter memorialístico dividido em três partes, cuja terceira inclui uma tentativa de determinar algumas bases teóricas da arte. ${ }^{9}$

Ainda no $\mathrm{XV}$, encontramos alguns tratados que procuram estabelecer para as artes figurativas fundamentos eminentemente ópticos e matemáticos. São eles, o De Prospectiva Pingendi, de Piero Della Francesca (cerca de 1415/20-1492), o primeiro pintor a enfrentar as problemáticas dos efeitos luminosos. Seu tratado, composto por três livros, é um estudo sobre a construção perspéctica estruturado sob bases matemáticas euclidianas, e que segundo Schlosser, é uma obra rigorosa, conduzida matematicamente de modo metódico e preciso. O primeiro livro discorre sobre pontos, linhas e planos. O Segundo, sobre corpos estereométricos e sua construção. O terceiro, sobre a realização perspéctica das colunas e estruturas arquitetônicas.

Outro estudioso de suma importância, matemático e tradutor de Euclides, é Luca Pacioli (1445- cerca de 1514), cuja profunda erudição gerou influência decisiva no pensamento e obras de Leonardo. Escreveu quatro tratados: Summa de arithmetica, geometria, proportioni et proportionalità (editado em 1494), De Divina proportione (impresso em 1503), um tratado sobre arquitetura (impresso também em 1503), e o Libellus de V corporibus regularibus (editado em 1507). De Divina Proportione representa a seção áurea da matemática antiga infinitas vezes aplicada à teoria da arte, enriquecida por elementos místicos e especulativos, cujo exame desemboca na doutrina dos cinco corpos regulares, importantes para os métodos construtivos do século XV. ${ }^{10}$

\footnotetext{
${ }^{8}$ Idem, ibidem, p. 91 a 98.

${ }^{9}$ Idem, ibidem, p. 101 a 106.

${ }^{10}$ Idem, ibidem, p. 140 a 142.
} 
Ghiberti já havia especulado sobre como enlaçar a arte sob um regime de leis e regras determinadas. Mas é com Leon Battista Alberti e suas obras De Pictura (1436), considerado a primeira expressão teórica do século XV, De Statua (1464) e o De Re Aedificatoria (1485), que, inicialmente, uma importantíssima prescrição de normas e um sistema para as artes figurativas chega a ser configurado de fato, principalmente no tocante a uma teoria da perspectiva e da proporção, acrescentando-se ainda os autores acima mencionados e seus estudos para uma argumentação estritamente matemática da arte.

Segue-se a esses primeiros teóricos, Leonardo, que, de posse de tais conhecimentos desenvolverá em seus manuscritos outros argumentos para esse novo caminho aberto, e que mais tarde serão reunidos no que convencionou-se denominar de Trattato della Pittura. A relevância desses primeiros teóricos está no fato de que eles delinearam uma nova doutrina para as artes figurativas, diferente do que a Antiguidade Romana ou a Idade Média Latina havia constituído. É nesse período que a teoria da arte propriamente dita começa a constituir-se enquanto tal, assentando profundas bases para a práxis artística.

Nesse configurar de um Primeiro Renascimento, a incessante procura por uma normatização e fundamentação das artes figurativas sob bases teóricas originava-se em causas específicas e pressupunha simultaneamente a conquista de determinados objetivos. O principal deles era fazer com que tais artes, seja pintura ou escultura, que haviam sido atreladas à idéia de um fazer mecânico vindo da Idade Média, cujas raízes originavam-se no mundo romano, pleiteassem uma legitimação enquanto conhecimento digno de homens livres. Na Roma antiga as artes liberales que tomavam parte no corpo dos studia liberalia eram estudos que não serviam para ganhar dinheiro e só podiam ser realizados por homens livres e não escravos. Deste modo, manuais de pintura e escultura eram classificados como artes mecânicas, dado serem executadas por artesãos incultos e consideradas destituídas de conceitos teóricos. Assim, era premente reivindicar um papel digno a essas artes, provando serem elas também decorrentes de procedimentos mentais e saberes matemáticos, como o eram a música e a arquitetura.

Nesse sentido, urgia àqueles primeiros tratadistas fundamentá-las sob bases científicas e evidenciar que elas poderiam e deveriam ser concebidas a partir de conceitos matemáticos tanto quanto outras artes, o que seria comprovado pela construção da 
perspectiva e pelo cânone de proporção das figuras. Com esse caminho tomado, eles estariam aptos a demonstrar que as artes figurativas eram também uma importante forma de conhecimento do mundo (por sua capacidade de representação de todos os elementos da natureza). De um mundo que vinha sendo descoberto, investigado e decifrado por homens cônscios de sua capacidade intelectual para encontrar suas próprias respostas sem aceitar a Igreja como a única detentora da sabedoria. Por conseguinte, seria possível defender as artes figurativas da denominação de simulacro com que Platão lhes havia cognominado desde a Antiguidade Grega. Provar que, enquanto forma de conhecimento vinculada a preceitos científicos, elas mereceriam figurar entre as "artes liberais" e não mais ser julgadas como ofício servil. Por fim, nobilitar o papel do artífice, que, de homem rude e inculto posicionado a uma ocupação servil, passaria a ser prezado como douto e letrado.

O árduo caminho tomado por esses primeiros artífices ocultava o recôndito anseio por uma real valorização e dignificação das artes figurativas, e, fundamentalmente, de uma nobilitação de seu ofício no quadro social de seu tempo.

No século XVI, o processo de aquisição de conhecimentos e prescrição de normas científicas para as artes figurativas, no tocante a questionamentos de ordem prática, já havia se consolidado. Restava aos teóricos da posteridade retomar as premissas daqueles primeiros estudiosos, em particular Alberti e Leonardo, e desenvolver novos estudos e doutrinas para as artes figurativas sob novos pontos de vista, como a elaboração de fundamentos mais propriamente estéticos, argumentando-as quanto à sua natureza essencial, seu conteúdo e o seu fim, incluindo discussões sobre os conceitos de mimese e beleza. Entre os mais importantes encontram-se Giorgio Vasari, Giovan Paolo Lomazzo, Giovan Battista Armenini, Federigo Zuccaro.

Inserem-se igualmente nesse quadro de referências os dois tratadistas objeto desta pesquisa Paolo Pino e seu Dialogo di Pittura, (1548) e Lodovico Dolce, com a obra Dialogo della Pittura, intitolato L'Aretino, (1557), são autores dos primeiros escritos venezianos sobre pintura, que foram idealizados como um diálogo de teóricos do Vêneto em relação à argumentação da arte desenvolvida na região Tosco-romana.

Em termos de erudição no âmbito da teoria artística, o humanismo toscano apresenta um aspecto peculiar em relação ao veneziano. Os teóricos toscanos sedimentaram suas 
investigações enfatizando os procedimentos científicos, matemáticos e ópticos. Já os teóricos venezianos optaram por pensar a arte de acordo com uma argumentação mais histórica, poética e filosófica. Porém, o trânsito de humanistas pelas diversas cortes e regiões da Itália permitiu, entre os séculos XV e XVI, um fluxo e intercâmbio de idéias e conhecimento, como no caso da filosofia, em que conceitos aristotélicos e platônicos entrelaçavam-se muitas vezes nas premissas de um mesmo autor. Se na Itália central humanistas, cientistas e filósofos de porte ganharam maior destaque, entre eles, Alberti, Leonardo, Marsilio Ficino, Pico della Mirandola, Giorgio Vasari e Giovanni Bessarion, a Itália setentrional não deixou de se iluminar com artífices letrados, como Giulio Campagnola e eruditos como Marcantonio Michiel, Pietro Bembo e Emolao Barbaro. Pino e Dolce são frutos desse ambiente.

Apesar da equiparação de similitude a que submetemos os dois tratadistas com o intuito de atingir o objetivo desta pesquisa, é preciso salientar, contudo, a grande diferença intelectual e humanística entre ambos. Pino é um pintor menor, aspirante a homem letrado. Dolce, por sua vez, é um humanista culto. Descendente de uma antiga família veneziana fez seus estudos em Pádua. Entre outras obras, traduziu para o vulgar a Arte Poética, de Horácio e o De Oratore, de Cícero, foi curador de obras de Dante, Petrarca, Boccaccio e autores contemporâneos seus como Lodovico Ariosto, Pietro Bembo e Baldassare Castiglione. Escreveu dois outros tratados, um sobre a memória e outro sobre as cores. Devido ao domínio da língua latina, de conhecimentos lingüísticos e retóricos, literariamente o tratado de Dolce é melhor concebido e de maior relevância do que o de Pino.

De toda forma, os dois escritos englobam muitas semelhanças quanto à ordem estrutural e temáticas argumentadas e algumas poucas diferenças, no que se refere às teses propostas e ao escopo com que foram escritos. Uma dessas diferenças está no período de sua criação, sinalizado pela ocorrência de dois marcos, o desenrolar da Contra-reforma e a publicação da obra de Giorgio Vasari, as Vite.

A obra de Pino, por ser pré-vasariana, apresenta ainda um caráter de paridade e continuação dos escritos anteriores, como os de Alberti, Leonardo, e ainda de outros tratados como os de Pomponio Gaurico e Albrecht Dürer, também com quem ele dialoga. 
Não há uma abordagem histórica no Dialogo. É de fato uma discussão da pintura sob a via dos mesmos preceitos de seus antecessores. A obra de Vasari é citada como ansiosamente esperada, e a Contra-reforma ensaiava nesses anos os seus primeiros passos. A conseqüência das normas ditadas pelo Concílio de Trento terá lugar um pouco mais tarde.

Por sua vez, o tratado de Dolce é profundamente influenciado por aqueles dois marcos históricos. Dolce dialoga abertamente com a obra de Vasari no âmbito histórico, chegando mesmo a utilizar alguns de seus argumentos e a tecer pequenos comentários biográficos de pintores já presentes na obra do florentino. Em outras passagens, atesta opiniões em acordo com os pressupostos do Concílio, ao realizar críticas à obra de Michelangelo.

As similaridades que se entrelaçam nos dois tratados encontram-se em algumas temáticas apresentadas pelos autores, que possibilitariam entrever uma harmonia de pensamento entre eles, servindo, ao mesmo tempo, para contornar uma teoria de arte especificamente veneziana. Contemporâneo aos dois tratadistas foi o notável teórico Marcantonio Michiel (1484-1552), descendente de uma antiga família patrícia veneziana da qual três tornaram-se doges. Segundo Schlosser, foi um homem de finíssima educação artística e teve estreitos laços com artífices e doutos. Idealizou um relato das vidas de pintores e escultores modernos o qual pretendeu editar, as Vite de'pittori e scultori moderni, porém, a publicação de sua obra foi interrompida ao ter conhecimento da impressão daquela de Vasari. Encontrou sempre ao longo da vida muita relutância em publicar seus manuscritos. Delas somente restou uma descrição da cidade de Bérgamo. Quase perdida para a história da arte ficou sua obra Le Notizie del disegno, que chegou até nós incompleta, ainda em caráter de esboço, e jamais destinada à impressão. Continha informações sobre obras de arte do Vêneto e da Lombardia, dispostas segundo a topografia: Pádua, Cremona, Milão, Pavia, Bérgamo, Crema, Veneza, e malgrado o estilo sucinto, revelavam uma rica vida interior e uma visão elevada. Sua obra se concluída nos teria fornecido dados os quais nem Vasari pudera dispor, porque tratavam da Itália setentrional de cujas notícias ele era informado escassamente. Teríamos tido em confronto ao especialista toscano, bastante 
limitado à sua região, as palavras notáveis desse distinto amador e conhecedor da arte veneziano. $^{11}$

De acordo com Rodolfo e Anna Pallucchini os apontamentos de Michiel personificaram uma recordação de obras e monumentos venezianos e de outras cidades da Itália Setentrional, cujo título Notizie d'opere di disegno nella prima meta del secolo XVI .., foi editada em 1800 pelo Abade Morelli. Esta obra constituiu um testemunho histórico e crítico de primeira ordem, especialmente por apontar a mudança de gosto do século XV para o XV, e pela compreensão vivaz de culturas artísticas estrangeiras, como a flamenga. Apesar de ter sido expressa de forma fragmentária, esses fragmentos caracterizam-se por apresentar um equilíbrio e uma amplidão de interesses de ordem estética que surpreendem e que talvez faltem até mesmo na obra do próprio Vasari. ${ }^{\mathbf{1 2}}$

Outra obra anterior aos tratados foi a Hypnerotomachia Poliphili, de autoria do monge Fra Francesco Colonna, publicada em Veneza, no ano de 1499. Pesquisas recentes revelaram ser Colonna não veneziano, mas de origem romana. Trata-se de uma obra de cunho alegórico na tradição do "Romance da Rosa", inspirada na poesia didascálica enunciada por Dante e obra que apresenta ainda elementos medievais e clássicos.

Segue-se, então, Paolo Pino, que concebeu o seu Dialogo di Pittura, publicado em 1548 com o propósito de realizar uma discussão com o tratado Da Pintura de Leon Battista Alberti, editado em língua latina na Basiléia, em 1540, e recém traduzido para o italiano por Lodovico Dominichi um ano antes, em 1547, estabelecendo uma análise que visava pontuar as temáticas expostas por Alberti, sob paradigmas artísticos venezianos. Pino menciona Alberti na carta endereçada aos leitores, onde argumenta que o caráter de seu tratado é mais matemático do que propriamente sobre teoria da pintura. Conforme exposto por Mary Pardo em sua edição crítica de 1984, incluindo a tradução para o inglês do Dialogo de Pino (e

\footnotetext{
${ }^{11}$ Idem, ibidem, p. 215 e 216.

12 PINO, Paolo. Dialogo di Pittura. Edizione critica com introduzione e note a cura di Rodolfo ed Anna Pallucchini. Venezia, Edizioni Daria Guarnati, p. 51-52: “[...] gli appunti, presi da Marcantonio Michiel, a ricordo diretto di opere e di monumenti veneziani e di altre città dell'Italia settentrional, editi nel 1800 dall'abate Morelli col titolo di Notizia d'opere di disegno nella prima meta del secolo XVI ..., costituiscono una testimonianza storica e critica di prim'ordine, specialmente per il mutamento del gusto dal Quattro al Cinquecento e per la comprensione così viva di culture artistiche forestiere, come quella fiamminga. Ma non si tratta che di frammenti, i quali ancor più ci fanno rammaricare che il Michiel non abbia realizzato la sua opera storiografica; frammenti ad ogni modo che posseggono un equilíbrio ed una vastità di interessi estetici che sorprendono e che forse mancarono allo stesso Vasari".
} 
citado por Susanna Falabella, ${ }^{13}$ em sua também edição crítica de 2000), percebe-se estar subjacente no fluxo da conversação do diálogo de Pino uma tripartição de matérias semelhante àquela desenvolvida por Leon Battista Alberti em seu De Pictura: os fundamentos da pintura, a arte pictórica, o ofício do pintor. Alberti foi sua principal fonte. Num segundo plano encontramos o cânone de proporção tomado de Vitrúvio, alguns preceitos constantes no escrito de Pomponio Gaurico, de Albrecht Dürer, e das narrativas de Plínio, o Velho. A relevância do tratado no entanto, encontra-se, no pensamento de Alberti. É através do escrito de Pino que se observa pela primeira vez no ambiente veneziano um arrolar das principais matérias artísticas que vinham sendo argumentadas pelos artistas, letrados e doutos do período: a beleza natural versus beleza artística, a perspectiva, cânones de uma beleza feminina ideal, cânones de proporção das figuras, a pintura enquanto arte liberal, partição da pintura, as técnicas pictóricas, a importância da assinatura na obra, os maiores pintores de Giotto em diante, o cotejo entre pintura e escultura e, por fim, o pintor perfeito. São dois pintores os interlocutores de seu diálogo: o florentino Fábio, e o veneziano Lauro.

O Dialogo della Pittura, intitolato l'Aretino, de Lodovico Dolce, por sua vez, foi publicado em 1557. Seu objetivo foi o de estabelecer um diálogo com a obra de Giorgio Vasari: Le vite dei più eccellenti pittori, scultori e architetti, publicada em 1550, com nova reedição em 1568, no sentido de asseverar a relevância da produção artística vêneta, colocando-a num mesmo patamar que a arte da Itália central, louvada de modo proeminente por Vasari, em detrimento da arte de outras regiões italianas. Do mesmo modo, visava refutar a divindade por ele criada em torno da figura de Michelangelo, defendendo a maestria de Rafael e a grandeza e primazia de Ticiano no cenário artístico italiano.

O diálogo que Dolce estabelece com Vasari é tão relevante que ele não somente recomenda ao leitor a obra do pintor-letrado florentino, como também absorve algumas de suas concepções teóricas. No tocante à definição de pintura, por exemplo, Dolce declara tratar-se de uma reunião de figuras, intrincadamente dispostas e relacionadas à história narrada, na qual o artista deve trabalhar de acordo com a sua inventio, através de uma série de esboços preliminares, como havia feito Rafael. O mesmo já prescrevera Alberti, ao

\footnotetext{
${ }^{13}$ PINO, Paolo. Dialogo di Pittura. Edição crítica aos cuidados de Susanna Falabella. Roma, Lithos Editrice,
} 
salientar a importância da história a ser contada e o quanto as figuras deveriam se submeter a ela. Dolce assevera que o artista deve seguir a prática romana de vestir os ossos com carne, e as carnes com os drapejamentos, (afirmação também presente no tratado de Pino), de modo que ele adquira proficiência por meio não só de uma constante prática, mas também de um estudo acurado dos modelos dos grandes mestres da Antiguidade. Outros momentos nos quais Dolce retoma e reitera Vasari encontram-se no início de seu diálogo, quando acolhe a divisão da pintura veneziana em três períodos distintos propostos por ele: o primeiro pertencendo a Giovanni Bellini, seguido por Giorgione e finalmente por Ticiano. Reflete Vasari novamente em outras passagens, como quando elenca aqueles que considera os oito pintores capitais do século XVI, ou quando estabelece paralelos com as Vite, em sua exposição de conceitos e explicações de princípios teóricos.

Outra fonte utilizada por Dolce foi, como em Pino, o Da Pintura, de Alberti, do qual adotou algumas observações de ordem técnica, como a discussão sobre a variedade e o movimento das figuras. Mark Roskill, ${ }^{14}$ que fez uma edição crítica do tratado de Dolce, afirma que a influência que Alberti exerceu nele fez-se presente somente na medida em que ele o tomou como um guia a fim de compreender e levar a cabo os preceitos teóricos de Vasari, que precisava dominar, visando consolidar suas próprias concepções artísticas.

Dolce influenciou-se também pelo De Sculptura, de Pomponio Gaurico, pelo comentário de Daniele Barbaro à obra de Vitrúvio, cujas menções em seu diálogo são evidentes, e por fim, por três outros tratados publicados antes do seu, que Dolce certamente deve ter tido acesso: o Disegno, de Anton Francesco Doni, o Della Nobilíssima Pittura, de Michelangelo Biondo, ambos de 1549, e certamente o Dialogo di Pittura, de Paolo Pino, de 1548, cujos reflexos em seu texto são óbvios, sem no entanto haver qualquer tipo de menção a nenhum deles. Não obstante Roskill afirmar não ser possível encontrar evidências contextuais destes autores no escrito de Dolce, de modo tão explícito quanto as outras fontes, admite encontrar certas analogias entre Pino e ele. Esclarece, porém, ser plausível que Dolce tenha lido diversos tratados publicados em anos anteriores, a fim de que obtivesse conhecimento e base suficientes para conceber o seu próprio, uma vez que ele

2000.

${ }^{14}$ ROSKILL, Mark W. Dolce's Aretino and Venetian Art Theory of the Cinquecento. Toronto, University of Toronto Press, 2000. 
começou a redigi-lo ainda pelos anos de 1550, (quando aqueles tratados já circulavam pelos meios eruditos de Veneza) para publicá-lo somente em 1557. E a pesquisa instrumental de outros textos artísticos deveria ser-lhe de extrema utilidade, uma vez que seu conhecimento teórico e familiaridade delineavam-se em torno da literatura e da lingüística, sendo-lhe a arte uma área pouco conhecida. Não obstante, era um conhecimento necessário a adquirir, por ser matéria amplamente debatida nos círculos humanistas que freqüentava.

O diálogo de Dolce é, portanto, o discurso resultante do entrelaçamento dos diversos tópicos presentes em outros escritos, que eram igualmente constantes nos debates dos círculos humanistas que ele tomava parte, somados à sua opinião sobre eles e a contribuição pessoal de seu extenso conhecimento sobre literatura. Resta conjeturar quanto do saber é atribuído a Aretino, que pelo amplo convívio com artistas mantinha com eles um vasto epistolário através do qual expunha seus pensamentos sobre arte. É ainda possível levantar a hipótese de que o diálogo tenha sido construído a quatro mãos, com apoio e sugestões pertinentes do poeta/escritor ao letrado.

\section{A escolha dos interlocutores de Dolce:}

O Dialogo della Pittura, foi publicado em 1557, e tem como interlocutores Pietro Aretino e Giovan Francesco Fabrini. Aretino (1492-1556) foi autor de tragédias, comédias, epístolas, sonetos e diálogos. Nascido em Arezzo, na Toscana, fixou-se em Veneza a partir de 1527, onde conquistou fama, poder e proteção de pessoas ilustres. O gramático Fabrini (1516-1580), natural de Figline, e igualmente toscano, foi chamado a Veneza para ocupar uma cátedra de Eloqüência, onde permaneceu por trinta anos ensinando esta disciplina. Traduziu a obra de Francesco Patrizi De institutione republicae, com o título Della interpretazione della lingua volgare e latina (1544). Escreveu também Teorica della lingua (1548) e fez comentários sobre o Terêncio latino e obras de Horácio.

Segundo Roskill, vários foram os fatores que levaram à escolha dos interlocutores. No que se refere a Aretino, Dolce atribuiu-lhe a proeminência das argumentações, porque já experimentava a sua convivência desde os anos de 1530, quando dedicou a ele a sua tradução da Arte Poética, de Horácio. Aretino era uma liderança eminente junto ao círculo literário e artístico veneziano do qual Dolce fazia parte. Havia sido ativo neste meio de 
modo ininterrupto por quase trinta anos, período no qual exerceu a função não somente de patrono de Ticiano, mas também fomentador e porta-voz de suas qualidades artísticas. E, por fim, fora autor de um vasto epistolário publicado através do qual fazia comentários sobre a arte e a cena artística de Veneza.

Quanto a Fabrini, Dolce o posicionou enquanto interlocutor coadjuvante no tratado, por três motivos: primeiro, Fabrini era um letrado de comprovada habilidade que ocupava um posto de distinção no ensino em Veneza. Muitos dos argumentos expostos entre ele e Aretino no diálogo apresentam uma gama de referências pertinentes à crítica contemporânea e à teoria da literatura num âmbito geral. O próprio Dolce, por volta de 1550, período em que começou a redigir o diálogo, dedicava-se à teoria lingüística e trabalhava em edições literárias. Segundo, Fabrini, por ser toscano, tornava-se uma pessoa qualificada para tomar o papel de porta-voz da Itália central e expor as considerações artísticas daquela região, em especial ao fazer uma defesa da obra de Michelangelo. E, por último, Fabrini havia trocado correspondências com Aretino, quando de sua chegada a Veneza em 1547.

No Renascimento, estudos, comentários e traduções de manuscritos antigos, propiciaram a difusão do pensamento de filósofos gregos, principalmente Aristóteles e Platão. Este fato acabou por gerar na teoria artística do século XVI um entrelaçamento de noções pertencentes ao sistema destes dois pensadores, às vezes no escrito teórico de um mesmo autor. Tal característica está presente nos tratados de Pino e Dolce. Poderíamos afirmar que categorias aristotélicas são mais claramente perceptíveis, principalmente no que concerne à discussão sobre a mimesis. O pensamento platônico, por sua vez, é esboçado por meio das obras de autores retóricos como Cícero e Quintiliano. Mesmo em se tratando de uma confluência de noções filosóficas gregas, é possível delinear nos dois tratados pequenos aspectos que nos permitam vislumbrar uma teoria da arte especificamente veneziana, demonstrando uma dissonância em relação àquela operada na região ToscoRomana. 


\section{Capítulo I O conceito de mimesis}

Enquanto alicerce da teoria das artes figurativas, situando sua origem na Antiguidade Clássica, a noção da mimesis ${ }^{15}$ tornou-se igualmente axioma fundamental da estética do Renascimento em sua retomada daquele período histórico, sendo prescrita por vários teóricos tratadistas ao longo dos séculos XV e XVI, entre os principais, Leon Battista Alberti no seu Da Pintura e, em Leonardo da Vinci, em seu Tratado da Pintura. Já no século XIV a noção de imitação havia sido mencionada por Boccaccio em seu Decameron para se referir à habilidade de Giotto em pintar de modo tão acurado as coisas naturais, que os homens se equivocavam ao tomar suas pinturas por realidade. No século XV o preceito tornou-se prática constante do ofício de artífices que buscavam um ponto de vista naturalístico, principalmente entre aqueles que se empenhavam de modo extremo em capturar a perfeita ilusão da natureza visível. Apesar da Poética de Aristóteles ser ainda desconhecida nesse período (somente no XVI é que surgirão estudos e comentários da obra), os artífices renascentistas estavam cientes de que o procedimento já havia sido concorde entre os homens da Antiguidade greco-romana, uma vez que eles haviam tido acesso às narrativas de Plínio, o Velho em sua História Natural, publicada na versão latina em 1469, e no italiano vulgar em 1476, por Cristoforo Landino.

Segundo Erwin Panofsky, a obra de arte enquanto reprodução fiel do mundo natural foi uma concepção que a teoria artística do Renascimento absorveu da Antiguidade e a revivificou, tirando-a de um esquecimento milenar, pois, apesar de ser um procedimento manifesto entre os antigos, fora rejeitado pelo Neoplatonismo e menosprezado pelos artífices da Idade Média. Plenos de sua fundamental relevância para a produção das artes figurativas, os teóricos renascentistas não só revigoraram o conceito de mimesis, como

\footnotetext{
15 KNOLL, Victor. Sobre a Questão da Mimesis. In: Revista Discurso do Departamento de Filosofia da USP. V. 27, 1996, p. 66: "Encontramos, de início, nos textos platônicos, e, logo em seguida, nos aristotélicos, a palavra mimesis, que a tradição historiográfica traduziu pelo termo "imitação". Cumpre desde logo salientar que esse termo desempenhou papel diverso no interior dos textos de cada filósofo. Mais ainda, pode-se dizer, que em Aristóteles, o termo mimesis ganha um alcance conceitual."
} 
também o promoveram à "dignidade de um verdadeiro programa artístico". ${ }^{16} \mathrm{E}$, como tal, a doutrina da imitação tornou-se tópica corrente no corpus da Literatura Artística, sendo inclusive argumentada em tratados como os de Paolo Pino e Lodovico Dolce.

A fim de atingir o escopo dessa pesquisa, que procura encontrar chaves de interpretação para o delineamento de uma teoria conceptiva da arte veneziana, estabeleceremos um cotejo entre os dois diálogos, no tocante a algumas temáticas discutidas pelos teóricos, bem como semelhanças e divergências entre fontes e argumentos presentes nos textos.

Num primeiro momento trataremos do conceito de mimesis. É matéria de suma importância nos dois diálogos por vincular-se à procura pelo artífice de um paradigma de beleza feminina, que se dá por meio dos procedimentos de representação da natureza. E igualmente por ser o imitar, na concepção dos teóricos, a própria definição de pintura. Correlato a este conceito está a visão de natureza e sua significação para ambos, uma vez que em seus preceitos a imitação deve se realizar com os elementos do mundo natural.

Como outros tratadistas, Paolo Pino e Lodovico Dolce estão embasados em pressupostos aristotélicos e vêem como fundamento da pintura ${ }^{17} \mathrm{o}$ imitar a natureza. ${ }^{\mathbf{1 8}}$ Apontam em seus textos algumas singularidades quanto aos procedimentos e um mesmo fim: a busca por um padrão de beleza feminina ideal.

A começar pelo tratado de Paolo Pino, observamos que diversas são as passagens em seu texto que refletem a prescrição de Aristóteles sobre a imitação ${ }^{19}$ em sua Poética ${ }^{20}$ e a influência do pensamento do filósofo grego ${ }^{21}$ exercida em seu diálogo ${ }^{22}$ :

\footnotetext{
${ }^{16}$ PANOFSKY, Erwin. Idea - Contribuição à história do conceito da antiga teoria da arte. São Paulo, Martins Fontes, 1994, p. 46.

${ }^{17}$ Idem, ibidem, p. 66: "Se confrontarmos a passagem sobre a techné tratada no "Livro X", da República com o peso que é conferido à mimesis na Poética, vemos a distância que separa cada um desses autores. Para Platão, mimesis detém uma carga negativa: é simulacro. Para Aristóteles, pode-se afirmar, é o próprio fundamento da obra de arte. [...]".

${ }^{18}$ Idem, ibidem: “[...] podemos dizer que a instalação do termo mimesis, por parte de Aristóteles, na reflexão estética, é a origem das questões conceituais da disciplina: desempenhou o papel de fundamento da obra de arte. Entretanto, como a mimesis no discurso aristotélico foi aliado à physis - à natureza -, e, por outro lado, por força das transformações da concepção de natureza - sobretudo a partir do Renascimento - presenciamos a desvalorização do conceito aristotélico de imitação. Mais precisamente, temos o seu esquecimento. Sabemos que o termo mimesis tal como foi manipulado por Aristóteles na Poética, indica o próprio estatuto do fazer artístico e do modo de ser da obra".

19 ARISTÓTELES. Poética. Tradução, prefácio, introdução, comentário e apêndices de Eudoro de Sousa. Porto Alegre: Editora Globo, 1966, p. 70: "A epopéia, a tragédia, assim como a poesia ditirâmbica e a maior parte da aulética e da citarística, todas são, em geral, imitações. Diferem, porém, umas das outras, por três
} 
“Outra regra não têm os pintores, que não seja imitar as coisas vivas e próprias"; "Dizei-me, se cada um tiver naturalmente o conhecimento das coisas, não deveria melhor entender a pintura como imagem do natural?"; ${ }^{24}$ "E dado que, todas as artes imitam a natureza, a pintura sobre todas as outras com maior integridade imita todas as coisas naturais $[\ldots]$ ”, “25 “...] porque a pintura é uma espécie de filosofia natural, uma vez que ela imita a quantidade e a qualidade, a forma e a virtude das coisas naturais [...]"; "A arte da pintura é ser imitadora da natureza nas coisas superficiais [...]"; ${ }^{27}$ "Não por isso quero que o nosso pintor enamore-se de outras pinturas, além de fazer figuras à imitação do natural, mas seja este seu fundamento e seu

aspectos: ou porque imitam por meios diversos, ou porque imitam objetos diversos, ou porque imitam por modos diversos e não da mesma maneira"

${ }^{20}$ LEE, Rensselaer W. Ut Pictura Poesis: The Humanistic Theory of Painting, in Art Bulletin, XXII, 1940, p. 201, nota 23, a Poética não era bem conhecida até o século XVI. A primeira tradução latina fidedigna que surgiu foi a de Giorgio Valla, publicada em 1498. O primeiro comentário, de Robortelli, em 1548. A primeira tradução italiana, de Segni, em 1549.

${ }^{21}$ PINO, Paolo. Dialogo di Pittura di Messer Paolo Pino nuovamente dato em luce. In Vinegia per Pauolo Gherardo, MDXLVIII. Edição fac-símile de 1548 (com nota de Giorgio Nicodemi), Milão, 1945, p. 4 e 7: "Leggete Aristotele e gli altri, che hanno detto de tal cosa [...]". "Et dice Aristotele, che um corpo mostruoso, è indegno de uma anima retta". Asserção, aliás, própria de Sócrates e não Aristóteles. Cf. Anexo, p. 9 e 21.

${ }^{22}$ É possível afirmar que a obra de Bernardino Daniello, La Poetica, publicada em 1536, também tenha exercido influência em Paolo Pino para a concepção de seu tratado, tanto quanto ocorreu com Lodovico Dolce.

${ }^{23}$ PINO, Paolo, op. cit., p. 4: “Altra regola non hanno i pittori, ch'imitare le cose vive e proprie”. Cf. Anexo, p.8.

${ }^{24}$ Idem, ibidem, p.5: "Ditemi? Se ciascui ha naturalmente la cognitione delle cose naturali, meglio dovrebbe intendere la pittura, come imagine del natural". Cf. Anexo, p.11.

${ }^{25}$ Idem, ibidem, p. 10: “[...] et dato, che tutte l'arti imitano la natura, questa sopra tutte l'altre, con maggior integrità imita tutte le cose naturali [...]".Cf. Anexo, p. 29-30.

${ }^{26}$ Idem, ibidem, p. 12: "[...] che la pittura è una specie de natural filosofia, perchè l'imita la quantità e qualità, la forma e virtù delle cose naturali [...]”. Cf. Anexo, p. 36-37. A pintura é uma filosofia porque ao investigar as coisas naturais imitando-as, o pintor obtém o conhecimento da própria natureza. Apenas salientamos que esta máxima pertenceu a Leonardo. LEONARDO. Trattato della Pittura. Roma: Grandi Tascabili Economici Newton, 1996, p. 6: "Adunque la pittura è filosofia, perchè la filosofia tratta del moto aumentativo e diminutivo, il quale si trova nella sopradetta proposizione; della quale faremo il converso, e diremo: la cosa veduta dall'occhio acquista tanto di grandezza e notizia e colore, quanto ella diminuisce lo spazio interposto infra essa e l'occhio che la vede. Chi biasima la pittura, biasima la natura, perchè le opere del pittore rappresentano le opere di essa natura, e per questo il detto biasimatore ha carestia di sentimento. Si prova la pittura esser filosofia perchè essa tratta del moto de' corpi nella prontitudine delle loro azioni, e la filosofia ancora lei si estende nel moto".

${ }^{27}$ Idem, ibidem, p. 15: "L'arte della pittura é imitatrice della natura nelle cose superficiali [...]”. Cf. Anexo, p. 45. 
estudo principal"; 28 "E porque a arte da pintura estende-se no imitar todas as coisas naturais e artificiais, não pouco importa que o pintor sinta deleite ao ver e entender semelhantemente todas as qualidades e natureza das coisas",29 “[...] imitando a natureza, a qual não só cuida em conservar a já perfeita planta, mas também lhe incita a produzir e nutrir seus rebentos [... $]^{\prime 30}$

Segundo Pino, pintura é imitação da natureza. Nesse sentido, ela segue os procedimentos da natureza, ou se dá conforme seus mesmos princípios. ${ }^{31} \mathrm{O}$ que em seu tratado implica dizer que, se a natureza gera todos os elementos que compõem suas obras, tais como forma, cor, volume, relevo, movimento, do mesmo modo, a pintura imita seus procedimentos, recriando idênticos elementos num suporte bidimensional. Desta forma, de acordo com Pino, mimesis corresponde a um preceito que todo pintor deve seguir, tendo por fim "representar" as coisas ${ }^{32}$ naturais com todas as suas propriedades, tal como faziam os pintores antigos que abstraíam do "verdadeiro", ou daquilo que se apresentava à vista, formas, proporções e medidas, elementos que significavam a ordem com que a natureza

\footnotetext{
${ }^{28}$ Idem, ibidem, p. 29: "Non però voglio, ch'il nostro pittore si inveschi in altre pitture, che nel far figure à imitatione del naturale, ma sai questo il suo fondamento e il suo studio prencipale [...] '. Cf. Anexo, p. 85-86. ${ }^{29} \mathrm{Idem}$, ibidem, p. 31: "Et perché l'arte della pittura s'istende nell'imitare tutte le cose naturali e artificiali, non poco importa, ch'il pittore habbi dilettatione di vedere e intendere similmente tutte le qualità e natura delle cose". Cf. Anexo, p. 89.

${ }^{30}$ Idem, ibidem, p. 34: "[...] imitando la natura, la quale non solo pone cura in conservare la già perfetta pianta, ma ancho le fà produrre e nodrire delli rampolli[...]”. Cf. Anexo, p. 92.

${ }^{31}$ KNOLL, Victor, op. cit., p. 68: "A posição fundamental que se pode assumir diante da Poética de Aristóteles e, como tal, dotada de um caráter de proposição norteadora da pesquisa é esta: a obra de arte é mimesis da physis. A obra de arte segue os procedimentos da physis, ou, se dá segundo o mesmo princípio da physis. Há um liame indestrutível entre a mimesis - a imitação - e a physis - a natureza. Tal é a lição que nos dá a recuperação, a partir dos textos de Aristóteles, dos termos mimesis e physis; aí está, antes de tudo, a referência para se efetuar o corretivo histórico em relação ao papel teórico desempenhado pelo termo imitação. Enquanto nos textos platônicos mimesis é designativo de um sub-estado (se assim podemos dizer), na Poética é francamente indicativa do estado próprio da tragédia e, hoje, por extensão, dizemos da obra de arte".

${ }^{32}$ Torna-se necessário observar em qual sentido Pino emprega a palavra "coisa". Pensamos que no tratado ele o aplique na acepção de "res" em detrimento de "coisa" na definição causa-origem. "Res" coloca-se enquanto fato, fenômeno da realidade, matéria, criatura. De acordo com Pino, seriam todas as formas, estruturas, espécies, seres animados e inanimados que constituem o cosmo que se apresenta diante dos olhos. Em outros momentos ele se utiliza do termo "obras naturais", como se a natureza fosse dotada de uma potência para criar suas próprias obras. Quando ele se refere a "coisas vivas e próprias", acreditamos que ele pretenda dizer, coisas animadas que apresentem propriedades de "forma, proporção, estrutura, volume, tamanho, cor", ou na verdade, todas as características específicas e inerentes que tornem tal "ser" apresentar-se como é. Assim optamos por usar na argumentação sempre as palavras "coisas naturais", ao invés de "formas naturais" ou "elementos naturais" que não são empregados no texto do autor.
} 
construía suas obras. ${ }^{33}$ Conforme Pino, é na medida em que o pintor imita a natureza em sua pintura, ou seja, busca representar num plano bidimensional a similaridade das formas naturais, que seu intelecto se torna capaz de capturá-las, compreendê-las e avaliá-las. A pintura deve realizar o mesmo efeito que faz o espelho, refletir a forma das coisas naturais. ${ }^{34}$ Ser uma imagem (quão mais próxima) ${ }^{\mathbf{3 5}}$ da natureza, consentindo ao pintor obter o conhecimento desse universo por meio da experiência e da prática. ${ }^{36}$ Em conformidade aos artífices-cientistas do século XV, o estudo da natureza, segundo Pino, configura-se também como instrumento de investigação deste mundo natural, na medida em que todos os elementos captados pelo olho tornam-se mais claros, compreensíveis e passíveis de serem julgados pelo intelecto, a partir do momento em que são representados na pintura. ${ }^{37}$ Tal qual uma filosofia especulativa que, procura o conhecimento da verdade por meio de causas e efeitos de acontecimentos e fatos.

Retornando à questão da mimesis, para Alberti, principal teórico com o qual Pino dialoga em seu tratado, a tarefa primeira do pintor deve ser a observação da natureza e o estudo de todos os seus elementos por meio do olho e da mente, pois a natureza é mestre e princípio da pintura. ${ }^{38}$

Neste contexto de intrínseca relação entre imitação e natureza, torna-se necessário definir qual conceito de natureza é empregado pelos dois teóricos venezianos, em especial Paolo Pino, pela demanda de seu ofício de pintor. Quanto à doutrina da imitação, sua fonte

\footnotetext{
${ }^{33}$ PINO, Paolo, op. cit. p. 4: “[...] volendo imitar quelle linee, proporzioni, misure et ordini, astratti quase dal vero, ch' i primi nostri inventori, per immortalarsi, instituirono le cose a modo loro, ben che l'invenzioni fossero (se dir si può) divine." Cf. Anexo, p. 8.

${ }^{34}$ Idem, ibidem, p. 5: "L'arte nostra fà l'effetto che fà lo specchio, il qual riceve in sè quella forma (senza il motto) che se gli oppone dinanzi." A observação sobre o espelho encontra-se tanto em Alberti como em Leonardo. Ora ele serve ao pintor como bom juiz a ponto de ajudá-lo a corrigir os erros que faz na pintura, ora ele mostra-se enquanto modelo, uma vez que reflete as coisas naturais em sua similitude. Nesse sentido, poder-se-ia dizer que a pintura deve ser um espelho da natureza, por ter o propósito de imitar numa superfície plana, todas as formas, relevo e movimento das coisas naturais. Cf. Anexo, p. 14

${ }^{35}$ Idem, ibidem, "[...] quando le cose dipinte fossero perfette come le naturali [...]".Cf. Anexo, p. 14

${ }^{36}$ Idem,ibidem, p. 4: "[...] la pittura ammette che l'intelletto vostro senza artifício possi esser capace do perfettamente intendere e giudicare tutte le cose naturali, ancor che gli antichi ispesero dietro a questa cognizioni il tempo e loro facultati, riducendo in arte per lo meggio dell'isperienza". Cf. Anexo, p. 9.

${ }^{37}$ Idem, ibidem, p. 11: "Ma liberale si può dir la pittura, la qual, come regina dell'arti, largisse e dona buona cognitione de tutte le cose create". Cf. Anexo, p. 33.

38 ALBERTI, Leon Battista. Della Pittura. Edizione critica a cura di Luigi Mallè. Firenze: G. C. Sansoni Editore, p. 106: "Così tutte queste cose lo studioso pittore conoscierà dalla natura et con sé stessi molto assiduo le examinerà in che modo ciascuna stia. Et continuo starà in questa investigazione et opera desto con suo occhi et mente".
} 
única é Aristóteles, mas, no tocante à noção de natureza, sua concepção apresenta ao mesmo tempo aspectos do pensamento platônico e aristotélico.

É preciso primeiramente discernir a qual das duas fases da teoria da natureza, que se desenvolveu entre os séculos XVI e XVII, Pino pertence. A primeira delas caracterizava-se por uma concepção orgânica da natureza, a segunda, por uma visão mecânica. No primeiro momento o mundo da natureza era considerado um organismo vivo, cujas energias e forças imanentes eram de caráter vital e físico, ao qual se atribuía razão e sentido, amor e ódio, dor e prazer, encontrando-se nessas faculdades e paixões as causas dos processos naturais. Sob este aspecto, esta cosmologia parecia-se quer com a de Platão, quer com a de Aristóteles e ainda mais com a dos pré-socráticos. ${ }^{39}$ A crise da cosmologia moderna teve início com a publicação póstuma da obra de Nicolau Copérnico (1473-1543), De Revolutionibus orbium coelestium. O verdadeiro significado de sua descoberta astronômica não se encontrava tanto em sua proposição de deslocar o centro do universo da terra para o sol, mas sim, negar que o mundo pudesse ter qual centro fosse. Com sua teoria heliocêntrica, ficava patente a idéia de que o mundo material não possuía mais um centro, e como tal destruía a idéia anterior da natureza como organismo.

"Um organismo implica em órgãos diferenciados, no organismomundo esférico do pensamento grego, havia a terra no meio, depois vinha a água, o ar, o fogo e por fim, para Aristóteles, a quinta essência do invólucro nas extremidades do mundo; ora se o mundo não tem centro, a própria base destas diferenciações desaparece; todo o universo é então feito da mesma espécie de matéria". 40

Uma vez sendo constituída da mesma matéria, a totalidade dos elementos do universo estariam também sujeitas à lei da gravitação e não somente as regiões sublunares. ${ }^{41}$ Este raciocínio demonstrou ao homem que seu poder de ação no mundo

\footnotetext{
${ }^{39}$ COLLINGWOOD, R.G. Ciência e Filosofia. Lisboa: Editorial Presença, 1981, pp. 107.

${ }^{40}$ Idem, ibidem, p. 109.

${ }^{41}$ Idem, ibidem, p. 109: “[...] todavia, fundamental nesta afirmação é que o mundo material não tem centro; e isso foi certeiramente considerado como uma revolução na cosmologia, pois destruía toda a teoria do mundo natural como um organismo. Um organismo implica órgãos diferenciados; no organismo-mundo esférico do
} 
poderia ser ampliado, uma vez que as leis científicas estabelecidas por ele na terra, poderiam ser igualmente aplicadas ao céu estrelado.

Segundo Collingwood, a importância filosófica das idéias de Copérnico encontra-se no fato de que sua tese principal dizia respeito à homogeneidade de substância existente entre a terra e os corpos celestes, havendo assim uma identidade nas leis que governam seus movimentos. ${ }^{42}$ As implicações das premissas postuladas por Copérnico germinaram as sementes para que filósofos posteriores iniciassem a segunda fase da teoria da natureza, entre eles Giordano Bruno (1548-1600), Francis Bacon (1561-1626), Johannes Kepler (1571-1630). Porém, esta fase mecânica consolida-se somente com Galileu Galileu (15641642), por volta de 1620. Para ele, a verdade inerente à natureza consistia em dados matemáticos, sendo que o real e inteligível no mundo natural é somente aquilo que é mensurável e quantitativo. Ele estabeleceu assim que a natureza podia e deveria ser objeto de conhecimento científico e exato. O princípio de sua ciência residia na premissa de que nada é cientificamente exposto ao conhecimento se não puder ser mensurável. Dessa forma, a natureza deixou de ser um organismo para tornar-se máquina, cujas mudanças e processos deveriam ser produzidos e dirigidos não por causas finais, mas por causas eficientes. ${ }^{43}$ Um mundo que deveria ser decifrado, compreendido e governado por leis científicas, podendo portanto ser manipulado e submetido pela ação humana.

Na primeira fase, orgânica, "a relação entre natureza e homem era concebida em termos de astrologia e magia, isto porque o poderio do homem sobre a natureza era visto não como poderio do espírito sobre o mecanismo, mas sim como o poder de uma alma sobre outra alma, o que implicava magia". 44

pensamento grego, havia a terra no meio, depois a água, depois o ar, depois o fogo e por fim, para Aristóteles, a quinta essentia do invólucro nas extremidades do mundo; ora, se o mundo não tem centro, a própria base destas diferenciações desaparece; todo o universo é então feito da mesma espécie de matéria, a lei da gravitação aplica-se não apenas às regiões sublunares - como Aristóteles pensava - mas a todo o lado, e as estrelas, em vez de serem dotadas de uma substância divina própria, são homogêneas com a terra."

${ }^{42}$ Idem, ibidem, p. 110.

${ }^{43}$ Idem, ibidem, p. 110 a 115.

${ }^{44}$ Idem, ibidem,p. 108: “[...]e aquilo que na natureza era mais exterior, ou esfera estelar, era ainda concebido em moldes aristotélicos como a mais pura e a mais viva ou ativa, ou infuente parte do organismo cósmico, e portanto como a causa de todos os acontecimentos ocorridos nas outras partes, conseqüentemente, como astrologia". 
Os argumentos de Pino em seu diálogo, no que diz respeito à natureza, e algumas categorias de cunho medieval, como a menção à doutrina dos quatro humores ${ }^{45}$ e pequenas referências à astrologia em pequenos trechos do tratado, inserem-no na primeira fase da teoria da natureza. Ao mencionar que os filósofos naturais não só indagaram os segredos, como também as razões, ordens e causas da natureza, ${ }^{46}$ ele faz alusão aos princípios estabelecidos pelos filósofos pré-socráticos que foram os primeiros a definir as coisas naturais a partir do que eram constituídas. Para estes, o mundo natural era um organismo vivo dotado de inteligência e mente próprias. Observamos que Pino apresenta o mesmo raciocínio, pois de acordo com ele a natureza é capaz de atribuir forma, relevo e movimento às suas coisas. É o mundo perceptível de corpos em movimento, composto de matéria ou forma, ${ }^{47}$ ao qual ele denomina de "verdadeiro". Pino não esclarece em seu tratado conceitos de matéria e de forma. Ora ele afirma serem a mesma coisa, ora assevera que matéria e forma são coisas diferentes como na seguinte frase: "Verdadeiramente todas as feituras naturais padecem oposições, o que causa a impotência da matéria, na qual a natureza imprime suas obras". 48 Ao declarar que a natureza imprime suas obras na matéria, poder-seia depreender que ela cria uma forma na matéria, o que neste caso, viria a ser aquilo que não se organizou em forma e que depende da potência da natureza para vir a sê-lo. Pensamos que o sentido que Pino confere a matéria esteja associado à concepção aristotélica. ${ }^{49}$ Assim,

\footnotetext{
${ }^{45}$ Ao se referir ao pintor como um ser melancólico.

${ }^{46}$ PINO, Paolo. op. cit. p. 7: “Troppo è difficil conoscere la perfettione de qual si vogli cosa, ma impossibil è poi trovare il vero nel proprio intrinseco di natura, anchor ch'i naturali filosofi, amatori della verità, indagando, svelorno molti suoi segreti e non pur dissero la natura della natura, ma assegnorno le ragioni, l'ordine e le cause". Cf. Anexo, p. 18.

${ }^{47}$ Idem, ibidem, p 23: “[...] perché sono istimati gli huomini e signalati uno dall'altro? Non già per la materia o forma, non già per li beni di fortuna, ma si bene per le virtù e arti [...]". A despeito de fora do contexto do texto acima, o exemplo acima serve para mostrar que a matéria para Pino tem o mesmo significado que forma. Cf. Anexo, p. 70-71.

${ }^{48}$ PINO, Paolo, op. cit.: p. 4: “Veramente tutte le fatture naturali patiscono opposizioni. Il che causa l'impotenzia della materia, nella qual essa natura imprime l'opere sue”. Cf. Anexo, p. 9.

${ }^{49}$ COLLINGWOOD, R. G. op. cit., p. 101: "Em si mesma, a matéria é para Aristóteles o indeterminado, aquilo que poderia estar, mas que não está organizado dentro desta ou daquela forma específica ou estrutura; por isso Aristóteles identifica freqüentemente matéria com potencialidade [...]" "[...] a matéria é o caso-limite ou ponto-de-dissipação no final negativo do processo da natureza: tudo na natureza está constantemente a desenvolver-se, quer dizer, a realizar-se ou a tornar-se na atualidade aquilo que era em potencialidade, e a matéria é a indeterminação que corresponde ao aspecto negativo da potencialidade." “ A matéria é, conseqüentemente, a não realização de uma potencialidade irrealizada; e porque não há uma coisa como uma potencialidade totalmente irrealizada, uma tendência que seja totalmente ineficaz, não há uma coisa como pura matéria; há sempre e por todo o lado matéria em processo de organização, matéria a adquirir forma. Mas
} 
poder-se-ia dizer que a forma em seu tratado é tudo o que incorpora-se em matéria e está sujeita a mudanças como relevo, movimento, acidentes. Esse organismo vivo que é a natureza, segundo as afirmações de Pino, é constituído de um caráter físico, autocriador, e de causas formais imanentes. ${ }^{\mathbf{5 0}}$ Quando ele diz: "[...] porquanto as proporções, como dissestes, não foram paridas pelos pintores, mas antes, recolhidas e tiradas das obras naturais, como ordem usada pela natureza em suas obras" ${ }^{\mathbf{5 1}}$, ele assevera que a natureza possui uma energia vital, de onde ela cria a si mesma, ou seja, que ela possui uma atividade intrínseca, em virtude da qual gera movimento em si própria, produzindo todos os vários tipos de estrutura encontrados no mundo natural: ${ }^{52}$ "[...] porque a natureza dá o relevo e o movimento às suas figuras, o que é impossível a nós". 53 A natureza possui uma força imanente que anima e dirige os processos e mudanças naturais. Nesse sentido, ora Pino aproxima-se de Platão que tendia a explicar o comportamento das coisas naturais como um efeito de sua estrutura matemática, ora aproxima-se de Aristóteles, para quem a natureza apresenta-se por uma tendência ou esforço para realizar formas ainda não existentes. Nesse sentido, pensamos que é Aristóteles de quem ele mais se aproxima, quando assevera que a potencialidade da natureza em gerar uma estrutura formal (dotada de beleza) sofre impedimentos ou acidentes que causam a impotência da matéria, de modo que aquela forma que deveria seguir uma ordem de mensuração, proporcionalidade e correspondência de membros, sai em desacordo com estes padrões. ${ }^{\mathbf{5 4}}$ Poder-se-ia dizer que o acidente seria uma eventualidade, uma causa fortuita e indeterminada que agiria para fazer com que a natureza deixasse de criar uma forma perfeita, em uma determinada circunstância. ${ }^{\mathbf{5 5}}$ Categorias

a matéria só desaparece completamente quando a forma está plenamente realizada e a potencialidade se torna atual $[\ldots] "$ ".

${ }^{50}$ PINO, Paolo, op. cit., p. 15: “[...] perché la natura imita sé stessa, e naturalmente tutti gli artefici amano le sue fatture, e molte fiate la natura lo dimostra, dipingendo da sé stessa nei marmi e tronchi diverse forme figurate, sè anco nel fumo e nube diversamente concernesi, e questo fa la natura con quella dilettazione che prende uno vedendo l'effigie sua nello specchio". Cf. Anexo, p. 45.

${ }_{51}$ Idem, ibidem, p. 4: "[...] impero che le proporzioni che diceste non forno partorite dai pittori, mas si bem raccolte e tratte dall'opre naturali, come ordine usato dalla natura nelle opere sue”. Cf. Anexo, p. 8.

${ }^{52}$ COLLINGWOOD, R. G., op. cit.: p. 106.

${ }^{53}$ PAOLO, Pino, op. cit.: p. 5: "[...] perchè la natura dà il rilevo e il motto alle sue figure, il ch'è impossibil a noi". Cf. Anexo, p. 13.

${ }^{54}$ Idem, ibidem, p. 4: "[...] altro non è bellezza, in ciascuna spezie creata, ch'una commensurazione e corrispondenzia de' membri prodotti dalla natura senza alcuno impedimento de mali accidenti". Cf. Anexo, p. 9.

${ }^{55}$ Idem, ibidem, p. 7: "Sinchè la memória è recente, lucidatini quali siano quelle parti mere naturali, prive de mali accidenti, e come la natura Possi da sé produr uma bella femina". Cf. Anexo, p. 18. 
aristotélicas como: acidente, matéria, qualidade, quantidade, potência, ordem, assim como questões referentes à experiência e à prática, são constantes em seu tratado.

De início, a doutrina da mimesis argumentada em seu diálogo destina-se a introduzir a comparação entre beleza natural e artística e tem um fim específico: instituir um modelo de beleza feminina. A discussão apresenta-se sob dois aspectos essenciais: o primeiro, a representação similar das formas naturais pelo pintor, o segundo, a seleção realizada por ele, das partes mais belas desta mesma natureza, a fim de atingir aquele paradigma (como havia feito Zêuxis). ${ }^{\mathbf{5 6}}$ Há ainda um terceiro aspecto, menos explícito, no qual Pino assinala que o pintor deva deixar-se atrair pela obra de outros pintores, mas que seja a imitação da natureza o seu maior fundamento e conhecimento principal. ${ }^{57}$ Observamos assim que, por esta sentença, Pino prescreve ao pintor não só o estudo, mas também, a imitação da obra de outros pintores. Nesse sentido, a concepção de um modelo de beleza feminina somente seria passível de se concretizar a partir da realização dos três procedimentos citados acima.

A beleza, objeto primeiro da imitação, está distribuída segundo Pino, por todo mundo natural, disseminando-se por cada um de seus elementos. Não há totalidade em uma única forma. Cabe, portanto, ao pintor, fazer uma seleção dessas partes e uni-las num todo em sua obra, a fim de conceber uma beleza feminina perfeita, envolvendo nesta atitude o ir além da natureza, superando-a, ao lhe corrigir suas imperfeições. ${ }^{\mathbf{5 8}}$

De acordo com Panofsky, em paralelo à idéia de imitação da natureza, posta como requisito primordial para a concepção das artes, e como tal devendo obedecer a uma exatidão formal e objetiva em relação aos elementos naturais, uma outra idéia surge nos escritos artísticos do Renascimento e que já estava presente na literatura antiga: o triunfo da arte em relação à natureza. E este dado devia-se a alguns fatores. Primeiro, à imaginação do artífice, cuja liberdade lhe possibilitava transformar a aparência dos elementos afastando-os

\footnotetext{
${ }^{56}$ Idem, ibidem, p. 4: "E per non incorrere nell'imperfettione, imitate Zeusi, che volendo appresso li Crotoniati dipignere una Venere, elesse tra tutte le giovanette della città cinque vergini, la beltà delle quali soppliva all'integrità della sua Venere, raccogliendo da una di quelle gli occhi, dall'altra la bocca e dall'altra il petto e in tal guisa reduceva a perfettione l'opera sua". Cf. Anexo, p. 9-10.

${ }^{57}$ Idem, ibidem p. 30: "Non però voglio, ch'il nostro pittore si inveschi in altre pitture, che nel far figure à imitatione del naturale, ma sia questo il suo fundamento, e il suo studio prencipale [...]".Cf. Anexo, p. 86.

${ }^{58}$ Este procedimento de "correção da natureza" em que o pintor seleciona suas melhores partes para compor a beleza em sua obra, torna relevante o conceito da techné grega, em que a arte é "pro-ducere", ou está em prol de conduzir, dirigir, fazer algo". No caso, o pintor faz uso da techné, a fim de corrigir a imperfeição dos acidentes naturais, conduzindo-os a uma perfeição em sua obra.
} 
de suas diversas variantes presentes na natureza e produzindo a partir deles formas completamente novas. Segundo, à sua inteligência que o capacitava, menos de "inventar" do que escolher e aperfeiçoar estes mesmos elementos, uma vez que ele tinha o poder e o dever de dar a contemplar uma beleza inexistente em sua completude no mundo natural. Assim, a despeito de ser estimulado a ser fiel à natureza, requeria-se também ao artífice que ele selecionasse entre a diversidade de suas formas, aquelas que fossem as mais belas, evitando toda deformidade principalmente no tocante às proporções, de maneira a se distanciar do puramente natural para elevar-se à representação da verdadeira beleza. Sendo o conceito de imitatio, tanto quanto a noção de electio, uma herança da Antiguidade, assim também o Renascimento exigiu de suas obras de arte simultaneamente uma fidelidade à natureza e a procura pela beleza, sem encontrar nestas duas proposições qualquer contradição. ${ }^{59}$

A tópica de uma superação da natureza está presente já na Poética, na qual, ao afirmar que a imitação das ações determina o caráter dos homens, distinguindo-os pelo vício ou pela virtude, ${ }^{\mathbf{6 0}}$ Aristóteles também pressupõe uma superação do mundo natural. E isso se dá quando ele assevera que tanto pintores como poetas imitam homens em três níveis, superiores, inferiores ou iguais a nós. Nessa declaração, cabe dizer que, no tocante aos primeiros, ele propõe ao poeta e ao pintor que não só imitem os homens como eles se nos apresentem à vista, mas que devam figurá-los de um modo superior, sem as imperfeições de caráter inerentes aos exemplares comuns existentes na natureza.

Volvendo o raciocínio para Dolce, observamos que seu tratado apresenta inúmeras semelhanças e poucas divergências em relação às temáticas debatidas por Pino, cuja fonte filosófica principal foi Aristóteles. Dolce, por sua vez, dialoga com as obras de Aristóteles, de Horácio e de Daniello. Concomitante ao escrito por Paolo Pino, Lodovico Dolce afirma

\footnotetext{
${ }^{59}$ PANOFSKY, Erwin, op. cit., p. 46, 47, 48.

${ }^{60}$ ARISTÓTELES, op. cit., p. 70: "Mas como os imitadores imitam homens que praticam alguma ação, e estes, necessariamente, são indivíduos de elevada ou de baixa índole (porque a variedade dos caracteres só se encontra nestas diferenças [e, quanto a caráter, todos os homens se distinguem pelo vício ou pela virtude]), necessariamente também sucederá que os poetas imitam homens melhores, piores ou iguais a nós, como o fazem os pintores: Polignoto representava os homens, superiores; Pauson, inferiores; Dionísio representava-os semelhantes a nós. Ora, é claro que cada uma das imitações referidas contém estas mesmas diferenças, e que, cada uma delas há de variar, na imitação de coisas diversas, desta maneira". "[...] e, assim, também nos gêneros poéticos que usam, como meio, a linguagem em prosa ou em verso [sem música]: Homero imitou
} 
que o pintor deva representar em sua arte as coisas que imita da natureza, em toda sua similitude. ${ }^{61}$ Do mesmo modo declara que pintura não é outra coisa senão a imitação da natureza, e o pintor que mais se aproximar de suas obras, mais perfeito mestre será. ${ }^{62}$ Seu preceito sobre a mimesis aproxima-se muito intensamente das palavras de Bernardino Daniello em sua Poetica ${ }^{63}$ e por Giorgio Vasari, em seu proêmio às Vite. ${ }^{64}$ A argumentação de Dolce apresenta, tanto quanto consta no diálogo de Pino, três momentos. Primeiro, a imitação similar da natureza pelo pintor. Em seguida, Dolce aborda dois aspectos deste procedimento, a eleição das partes mais belas da natureza, o que implica superá-la, com o fez Zêuxis ${ }^{65}$ (também em acordo com o exposto por Pino, tendo ambos como fonte o De Inventione, de Cícero) ${ }^{66}$ e a imitação a partir de um único modelo, como faziam os pintores antigos. ${ }^{67}$ E o terceiro momento mais específico do diálogo, em se tratando da mimesis, é

homens superiores; Cleófon, semelhantes; Hegêmon de Taso, o primeiro que escreveu paródias, e Nicócares, autor da Delíada, imitaram homens inferiores".

${ }^{61}$ DOLCE, Lodovico. Dialogo della Pittura, intitolato L'Aretino. in Trattati d'Arte del Cinquecento - Fra Manierismo e Controriforma. Vol. I. Bari: Gius. Laterza e Figli, 1960, p. 153: 'L' ufficio adunque del pittore è di rappresentar com l'arte sua qualunque cosa, talmente simile alle diverse opere della natura, ch'ella paia vera. E quel pittore, a cui questa similitudine manca, non è pittore, et all'incontro colui tanto più è migliore $\mathrm{e}$ più eccellente pittore, quanto maggiormente le sue pitture s'assomigliano alle cose naturali”. Cf. Anexo, p. 103.

${ }^{62}$ Idem, ibidem, p.152: "Dico adunque la pittura, brevemente parlando, non essere altro che imitazione della natura; e colui che più nelle sue opere le si avicina, è più perfetto maestro [...] aggiungo che il pittore è intento a imitar per via di linee e di colori, o sia in un piano di tavola o di muro o di tela, tutto quello che si dimostra all'occhio; et il poeta col mezzo delle parole va imitando non solo ciò che si dimostra all'occhio, ma che ancora si rappresenta all'intelletto. Laonde essi in questo sono differenti, ma simili in tante altre parti, che si possono dir quasi Fratelli”. Cf. Anexo, p. 102.

${ }^{63}$ DANIELLO, Bernardino. Della Poética. In WEINBERG, Bernard. Trattati di Poetica e Retorica del Cinquecento. Roma: Laterza Editore, 1970-1974. (texto retirado do site www.bibliotecaitaliana.it), p. 7: "Perciò che come l'imitazione del dipintore di fà con stili, con pennelli, e com diversità di colori (co'quali esso poi, la natura, gli atti e la sembianza o d'uomo o d'altro animale imitando, ci rende la imagine di quello al vivo somigliante, così quella del poeta si fà con la lingua e con la penna, con numeri et armonie".

${ }^{64}$ VASARI, Giorgio. Le Vite dei più eccellenti pittori, scultori et architetti. Roma: Newton Compton Editori, 1991, p. 35: "[...] alla vera imitazione della natura alla quale chi più si accosta è più perfetto".

${ }^{65}$ DOLCE, Lodovico, op. cit., p. 172: "Onde abbiamo lo esempio di Zeusi, che, avendo a dipingere Elena nel tempio de' Crotoniati, elesse di vedere ignude cinque fanciulle e, togliendo quelle parti di bello dall'una, che mancavano all'altra, ridusse la sua Elena a tanta perfezzione, che ancora ne resta viva la fama". Cf. Anexo, p. 118-119.

${ }^{66}$ Idem, ibidem: "Deve adunque il pittore procacciar non solo d imitar, ma di superar la natura". Cf. Anexo, p. 118.

${ }^{67}$ Idem, ibidem, p. 176: "Devesi adunque elegger la forma più perfetta, imitando parte la natura. Il che faceva Apelle, il quale ritrasse la sua tanto celebrata Venere che usciva dal mare (di cui Ovidio che, se Apelle non l'avesse dipinta, ella sarebbe sempre stata sommersa fra le onde) da Frine, famosissima cortigiana della sua età; et ancora Prasitele cavò la bella statua della sua Venere Gnidia dalla medesima giovane”. Cf. Anexo, p. 122. R. W. Lee afirma que, segundo Dolce, os artistas modernos não podem encontrar um padrão de perfeição em uma única mulher por natureza, uma vez que, mesmo nas melhores condições, ela não deixaria de 
aquele em que ele prescreve ao pintor o estudo das esculturas antigas, cuja perfeição pode auxiliá-lo a corrigir muitos defeitos da natureza. ${ }^{68}$ Pino havia indicado que o pintor se deixasse influenciar pela obra de outros autores. Dolce já elabora melhor este terceiro momento da imitação, apontando que o pintor deva tomar a estatuária antiga como paradigma de perfeição

O preceito de uma superação da natureza pelo pintor, já havia sido desenvolvido por Benedetto Varchi em sua conferência Due Lezioni, de 1549. Segundo ele, o pintor deveria imitar as obras naturais, procurando fazê-lo com certo discernimento, a fim de que pudesse efetuar correções, onde a natureza se mostrasse imperfeita. ${ }^{69}$ Os três aspectos da doutrina da imitação na concepção Dolce têm como fim (semelhante ao diálogo de Pino) estabelecer um padrão de beleza ideal. A particularidade do tratado evidencia-se pela idealização que Dolce estabelece da estatuária antiga encontra sua fonte principal nas Vite, de Giorgio Vasari, a despeito de outros autores como Horácio, Cícero e Quintiliano, Alberti, terem afirmado a importância da imitação de modelos, por parte de poetas, oradores e pintores. Com o propósito de conceber um modelo de beleza feminina perfeita, não basta ao pintor imitar a natureza, torna-se necessário que ele volte os olhos ao estudo das esculturas antigas, buscando representar a ordem clássica de beleza da Antiguidade. ${ }^{70}$ De acordo com Vasari, em se tratando da arte do desenho, quem quisesse aprender a exprimir os conceitos da alma ou qualquer outra forma, com o intuito de tornar-se mais inteligente nas artes, deveria se exercitar em retratar figuras de relevo feitas de mármore, outras pedras ou gesso

apresentar imperfeições, devendo portanto os pintores tomar como modelo, as esculturas antigas. Cf. LEE, R. W. op. cit., p. 205.

${ }^{68}$ Idem, ibidem, p. 176: "E parte se debbono imitar le belle figure di marmo o di bronzo de' maestri antichi; la mirabile perfezzion delle quali chi gusterà e possederà a pieno, potrà sicuramente corregger molti difetti di essa natura". Cf. Anexo, p. 122.

${ }^{69}$ Segundo VARCHI, Benedetto, Due Lezioni, Florence, 1549, p. 111 e ss. In LEE R. W., op. cit., p. 204, nota 40: "I dipintori, se bene nel ritrarre dal naturale, debbono imitare la natura, e sprimere il vero quanto più fanno, possono non dimeno, anzi debbono, come ancora i Poeti, usare alcuna discrezione, onde molto fu lodato la prudenza d'Apelle, il quale devendo ritrarre Antigono, che era cieco da uno occhio diede tal sito allá figura, che ascose quell'occhio di maniera, che non si poteva vedere".

${ }^{70}$ DOLCE, Lodovico. op. cit.: pp. 176 e 195: "[...] e far le sue pitture riguardevoli e grate a ciascuno, percioché le cose antiche contengono tutta la perfezzion dell 'arte e possono essere exemplari di tutto il bello". "La regola di giudicar questo bello di onde la cavate voi? Stimo che si debba cavar, come avete detto, dal vivo e dalle statue degli antichi”. Cf. Anexo, p. 122 e 140. 
e criadas a partir do ser vivo, ou então deveria se exercitar a partir de qualquer bela estatuária antiga. $^{71}$

R. W. Lee observou que o culto ao antigo produziu no século XVI, uma importante modificação da teoria aristotélica da imitação que teve resultados de longo alcance nas épocas posteriores. Aristóteles não havia aconselhado ao poeta a imitação de modelos, mas julgava que a imitação significativa da natureza seria uma função da imaginação seletiva do poeta e não dependia fundamentalmente de qualquer norma externa de perfeição relacionada ao antigo. Nem mesmo em sua doutrina da imitação de uma natureza superior, Aristóteles pretendeu expor que o poeta deveria desviar-se do mundo natural, o qual sempre poderia provê-lo de novos materiais para sua imitação seletiva, a fim de direcionar-se a uma idéia de perfeição a priori criada em sua mente. ${ }^{72}$

Nesse sentido, poderíamos afirmar que, no tocante à mimesis, um dos aspectos do diálogo de Dolce que o tornam tão peculiar, encontra-se, seguindo os passos de Vasari, na prescrição ao pintor da imitação da estatuária antiga, devido à qual Dolce propõe, numa primeira instância, uma alteração da doutrina aristotélica, uma vez que o filósofo grego jamais havia (conforme referido acima) preceituado a imitação de modelos ao poeta. E num segundo momento, uma aproximação maior com Horácio, em cuja Arte Poética, ele havia feito aos Pisões, o seguinte conselho: "Quanto a vós, compulsai de dia e compulsai de noite os exemplares gregos". ${ }^{73}$ Resta observar qual o conceito de natureza pesente em Lodovico Dolce.

A despeito de serem, Dolce e Pino, teóricos de ofícios diferentes, um pintor e um letrado, o conceito de natureza para ambos apresenta semelhanças. Conforme visto acima, há no diálogo de Pino trechos precisos que possibilitam depreender sua compreensão sobre

\footnotetext{
${ }^{71}$ VASARI, Giorgio, op. cit., p. 74: "Chi dunque vuole bene imparare a esprimere disegnando i concetti dell'animo e qualsivoglia cosa, fa di bisogno, poi che averà alquanto assuefatta la mano,che per divenir più intelligente nell'arti si eserciti in ritrarre figure di rilievo o di marmo, o di sasso, o vero di quelle di gesso formate sul vivo, o vero sopra qualche bela statuaria antica [...]. [...] Il qual disegno non può avere buon origine, se non s'ha dato continuamente opera a ritrarre cose naturali, e studiato pitture d'eccellenti maestri, e di statue antiche di rilievo, come s'è tante volte detto".

${ }^{72}$ LEE, Rensselaer W., op. cit., p. 207.

73 HORÁCIO. Arte Poética. Introdução, Tradução e Comentário de R. M. Rosado Fernandes. Lisboa: Editorial Inquérito Ltda., 1984, p. 94: "Vos exemplaria Graeca nocturna versate manu, versate diurna". E nota 268: "Horácio, com nova insistência, chama a atenção para os modelos gregos, que ele considera como os únicos dignos de serem imitados, por serem provenientes de uma técnica poética perfeita, que contrasta com a negligência romana".
} 
o mundo natural oriunda de noções do pensamento platônico e aristotélico. Enquanto organismo vivo que atribui formas belas disseminadas por todas as suas coisas, a natureza representa, para Pino, um objeto de estudo e investigação, de onde ele abstrai elementos para compor a sua obra. Por sua vez, o conceito de natureza para Dolce é de modo primordial, aristotélico: ela abarca a nominação de uma alma vegetativa. Ao discorrer sobre o colorido, Dolce afirma que a natureza pinta diversamente as coisas animadas e inanimadas; animadas, como são os homens e os animais irracionais; inanimadas, como os seixos, as ervas, as plantas e coisas tais, embora estas também sejam em sua espécie animadas, sendo elas partícipes daquela anima que é denominada vegetativa, a qual as perpetua e mantém. ${ }^{74}$ A alma vegetativa de que é dotado o mundo natural e da qual participam todos os seres vivos é, segundo Aristóteles, a causa e princípio dos corpos que vivem. A alma é causa devido a três modos definidos, porque ela é a origem, ou de onde e em vista de que parte o movimento gerador dos elementos sendo além de causa, também substância dos corpos animados. "Pois, para todas as coisas, a causa de ser é a substância, e o ser para os que vivem é o viver, e disto a alma é causa e princípio" 75 O tratado de Dolce não apresenta maiores digressões sobre o conceito de natureza. $\mathrm{O}$ mundo natural serve-lhe apenas de elemento para a argumentação de suas hipóteses, preceitos e desenvolvimento de seu raciocínio retórico.

Em Pino, a imitação e superação da natureza envolve a totalidade das coisas que a constitui, como fauna, flora e figura humana. Segundo Dolce, a superação da natureza pelo pintor somente é possível, no que diz respeito à representação da figura humana, porque quanto às demais obras, a natureza é milagrosa e insuperável, e por mais que o pintor a imite, consegue apenas aproximar-se de sua perfeição. Para Dolce, apenas a arte permite ao pintor demonstrar num único corpo toda a beleza que a natureza costuma revelar em um dentre mil. ${ }^{76}$ E esta beleza só pode ser demonstrada pela mecânica corpórea em seus

\footnotetext{
${ }^{74}$ DOLCE, Lodovico, op. cit., p. 164: "Il colorito serve a quelle tinte, con le quali la natura dipinge (che così si può dire) diversamente le cose animate et inanimate: animate, come sono gli uomini e gli animali bruti; inanimate, come i sassi, l'erbe, le piante e cose tali, benchè queste ancora siano nella spezie loro animate, essendo elle partecipi di quell'anima che è detta vegetativa, la quale le perpetua e mantiene". Cf. Anexo, p. 111.

${ }^{75}$ ARISTÓTELES. De Anima. Apresentação, tradução e notas de Maria Cecília Gomes dos Reis. São Paulo: Editora 34, 2006, p. 79-80.

${ }^{76}$ DOLCE, Lodovico, op. cit., p. 172: "Dico superar la natura in uma parte: ché nel resto è miracoloso, non pur se vi arriva, ma quando vi si avvicina. Questo è in dimostrar col mezzo dell'arte in un corpo solo tutta
} 
movimentos, os quais, por sua vez, conferem expressão aos movimentos da alma, às paixões ou afetos. E para atingir esse fim, ele deve, além de imitar a figura humana do natural, aperfeiçoá-la, corrigindo seus defeitos através do estudo da estatuária antiga, uma vez que, na consideração de Dolce, somente as esculturas da Antiguidade contêm toda a idéia de beleza perfeita da arte. ${ }^{77}$ Dolce as aprecia enquanto objetos de imitação em si mesmas, porque elas representam gloriosos exemplos de artistas antigos que reivindicavam para si a admiração da posteridade. Ao terem efetuado uma seleção do melhor da natureza para compor sua obra, eles conseguiram alcançar a perfeição. No aconselhar os artistas modernos ao seu estudo - o que os tornaria aptos a captar essa idéia de beleza que poderia se traduzir em várias formas como: galante, magnânimo, aprazível, e delicado, expressa para cada idade e ambos os sexos - o pintor poderia em certa medida ser tão bem sucedido quanto o foram os artistas antigos. $^{\mathbf{7 8}}$

De acordo com Rensselaer W. Lee, foi seguindo as normas propostas por Aristóteles e Horácio ditadas para a poesia, que Dolce concebeu seu conceito de mimesis da natureza, com ênfase na imitação da figura humana em movimento. E este preceito, por sua vez, serviu-lhe para edificar os fundamentos de sua teoria estética de uma doutrina da imitação ideal, que teria influência nos teóricos dos dois séculos seguintes. ${ }^{79}$ Assim como Aristóteles, em seus argumentos na Poética, prescreveu ao poeta a imitação do "ethos" na expressão de seus gestos e ações que refletem o caráter dos homens, Dolce, de modo similar, determina ao pintor a imitação da "figura humana", também em suas ações, movimentos e representações de afetos, mas buscando equiparar-se à ordem de proporcionalidade clássica das esculturas antigas.

quella perfezzion di belezza che la natura non suol dimostra a pena in mille; perché non si trova un corpo umano così perfettamente bello, che non gli manchi alcuna parte". Cf. Anexo, p. 118.

${ }^{77}$ Idem, ibidem, p. 176: "E per fare um corpo perfetto, oltre alla imitazione ordinaria della natura, essendo anco mestiero d imitar gli antichi, è da sapere che questa imitazione vuole esser fatta com buon giudizio, di modo che, credendo noi imitar le parti buone, non imitiamo le cattive; come veggendo che gli antichi facevano le loro figure per lo più svelte, v'è stato alcun pittore che, serbando sempre questo costume, è spesso trappassato nel troppo e quello ch 'era virtù ha fatto divenir vizio". Cf. Anexo, p. 122.

${ }^{78}$ LEE, op. cit., p. 210.

${ }^{79}$ LEE, Rensselaer W., op. cit., p. 204-205: "Dolce was probably aware of inconsistency, for he tries to square the first definition with the second by insisting that it is only in creating the human figure that the painter may improve upon nature; in all other respects he is hopelessly outclassed. The old notion of exact imitation Dolce can still accept with some enthusiasm for nature in general, but for the all-important human figure to which in Italian painting the rest of nature had always been subsidiary, it no longer do. And it is apropos of the human 
O apego de Dolce pela estatuária antiga poderia ter sido influenciado, além de Vasari, por outros autores. Alberti já havia declarado no Da Pintura, que agradava-lhe mais retratar uma escultura mediana do que uma ótima pintura, dado que, por meio da pintura, nada mais seria possível adquirir senão um maior conhecimento de imitação da natureza. No entanto, ao imitar as coisas esculpidas, poder-se-ia também, além de saber criar semelhanças, aprender como representar as luzes que nela poderiam incidir. Na prescrição de Dolce, o voltar os olhos às esculturas antigas tem o objetivo principal de fazer o pintor buscar imitar em suas pinturas, a perfeição de representação da figura humana contida naquelas obras. Já em Alberti, o escopo encontra-se no estudar o lume por meio do relevo das figuras.

Como referido acima, grandes retores tais como Cícero e Quintiliano, segundo Mark Roskill, ${ }^{\mathbf{8 0}}$ foram igualmente influências fundamentais para Dolce (da mesma forma quanto devem ter sido para o próprio Alberti). Quanto à imitação de modelos, podemos comprovar tal argumento pelos próprios preceitos desses autores latinos. Cícero havia exposto no De Oratore, que o estudo de modelos era essencial para o orador, e que o estudante de oratória deveria empenhar-se em imitar de tal forma o modelo por ele escolhido, de modo a atingir em seu desempenho as melhores qualidades que pudesse nele encontrar. ${ }^{81}$ E Quintiliano, nas Instituições Oratórias, seguindo a mesma linha de pensamento, havia declarado o quão significativo era para o aprendizado de um orador o estudo de modelos. De acordo com ele, em se tratando do orador, era preciso que ele formasse sua mente concomitante aos padrões de excelência existentes em cada arte. Se em qualquer arte uma não pequena porção da tarefa encontrava-se na imitação, embora a invenção viesse primeiro e fosse o aspecto mais importante da composição, estaria no expediente de imitar o que quer que fosse que tivesse sido inventado, o pleno sucesso. Para

figure in action that Dolce, following the method of literary critics of his day who were prescribing rules for poetry based on Aristotle and Horace, developed his own doctrine of ideal imitation".

${ }^{80}$ ROSKILL, Mark. W. op. cit.

${ }^{81}$ CICERO. De Oratore. Texto latino com tradução para o inglês de E. W. Sutton. Cambridge: Harvard University Press, 1948, p. 265, 267: "Let this then be my first counsel, that we show the student whom to copy, and to copy in such a way as to strive with all possible care to attain the most excellent qualities of his model. Next let practice be added, whereby in copying he may reproduce the pattern of his choice and not portray him as time and again I have known many copyists do, who in copying hunt after such characteristics as are easily copied or even abnormal and possibly faulty. [...] But he who is to proceed aright must first be 
Quintiliano, esta era uma regra universal de vida, porque todas as pessoas desejam copiar aquilo que encontram e aprovam nos outros. Sendo esta a razão devido a qual os jovens copiam as formas das cartas das quais eles podem aprender a escrever, os músicos apreendem as vozes de seus professores e os pintores, por sua vez, copiam os trabalhos de seus predecessores. Para ele, o estudo elementar de cada ramo de aprendizado está direcionado pela referência a algum padrão definido que tomou lugar antes do aprendiz. ${ }^{\mathbf{8 2}}$

Nesse sentido, o preceito de Paolo Pino, aconselhando o pintor a imitar não só a natureza mas também modelos de outros pintores, certamente teve Cícero e Quintiliano como suas fontes. E Dolce, além desses dois grandes retores, encontrou em Vasari, Alberti e Horácio, inspiração para prescrever ao pintor a consideração da estatuária antiga como paradigma de imitação perfeita em se tratando principalmente da figura humana.

É sabido que o retorno às fontes da Antiguidade, tão característico do Renascimento, foi teorizado em primeiro plano por humanistas como Petrarca e Boccaccio. Cada um considerou-as sob aspectos diferentes. Petrarca, após sua visita a Roma em 1337, concebeu o antigo enquanto nova proposição historiográfica. A Antiguidade apresentava-se-lhe enquanto período de grande esplendor, seguido após a conversão de Constantino, por um momento de decadência. Sua visão, porém, não se direcionava ao aspecto estético em relação ao antigo, mas ele o contemplava como ponto de partida que permitia obter o conhecimento literário do passado, suas implicações arqueológicas, políticas e morais. Boccaccio, por sua vez, prescreveu um retorno intencional às fontes antigas, que se desenvolverá no ambiente humanístico sem influenciar os artistas, que no século XIV não tinham muito contato com os letrados por ainda serem estimados artesãos incultos. A partir do momento em que as relações entre as duas ordens sociais se estreitaram, no início do século $\mathrm{XV}$, a paixão pelo antigo e a vontade de tomá-lo por modelo, foi transmitida pelos

watchful in making his choice, and afterwards extremely careful in striving to attain the most excellent qualities of the model he has approved".

82 QUINTILIAN. The Institutio Oratoria. With an english translation by H. E. Butler. Cambridge Massachusetts: Harvard University Press, 1998, p. 75: "It is from these and other authors worthy of our study that we must draw our stock of words, the variety of our figures and our methods of composition, while we must form our minds on the model of every excellence. For there can be no doudt that in art no small portion of our task lies in imitation, since, although invention came first and is all-important, it is expedient to imitate whatever has been invented with success. And it is a universal rule of life that we should wish to copy what we approve in others. It is for this reason that boys copy the shapes of letters that they may learn to write, and that musicians take the voices of their teachers, painters the works of their predecessors [...]". 
letrados aos artistas que passaram a considerá-lo sob uma nova luz, e não unicamente como simples documento. Conseqüentemente, os artífices começaram a efetuar investigações arqueológicas das ruínas presentes em várias regiões da Itália, principalmente Roma, as quais tornaram-se cada vez mais freqüentadas por eles. ${ }^{\mathbf{8 3}}$ A partir desses elementos, as descobertas arquitetônicas e escultóricas resultantes das ruínas, sua conseqüente restauração e o sucessivo estudo, tradução e elaboração de comentários sobre obras antigas, fizeram com que a longínqua Antiguidade, se tornasse um grande mito para os artífices e eruditos do Renascimento, que volveram todo seu foco e potência criadora para ela.

Encontramos tais características também em Pino e Dolce. Certamente em Lodovico o apego ao antigo foi maior, por ser ele um letrado e por ter tido uma grande familiaridade com as obras desses autores que foram os primeiros a preconizar este retorno dos eruditos às fontes antigas, como visto acima: Dante, Petrarca e Boccaccio e a influência que eles exerceram em sua formação. Além do contato com a obra de autores como Plínio, o Velho, ${ }^{\mathbf{8 4}}$ Vitrúvio, a obra de Vasari, as cartas de Pietro Aretino, ${ }^{\mathbf{8 5}}$ as obras de Pietro Bembo, ${ }^{\mathbf{8 6}}$ uma vez que todos à sua maneira faziam menção à excelência de artífices antigos

${ }^{83}$ DACOS, Nicole. L'esperienza dell 'antico, dell 'Europa, della religiosità - Arte Italiana e Arte Antiga in Storia dell Arte Italiana. Torino: Giulio Einaudi Editore, 1979, pp. 6-7.

${ }^{84}$ DOLCE, Lodovico, op. cit., p. 146: “[...] lasciando però da parte gli Apelli et i Zeuxi, i quali, non meno per testimonio de'poeti e scrittori antichi Che per quello che di leggeri si può conoscere dalla eccellenza di quelle poche statue che ci sono state lasciate dalle ingiurie del tempo e delle nazione nimiche, possiamo giudicar che fossero mirabilissimi”. Esta citação encontra eco em três autores que escreveram afirmações semelhantes, Pietro Aretino em uma de suas cartas, Pietro Bembo em sua obra: Prose della língua volgar, Castiglione em seu Il Cortegiano. Cf. Anexo, p. 98.

${ }^{85}$ CAMESASCA, Ettore, IXXIX. In ROSKILL, Mark W. op. cit., p. 227: "De le scolture non parlo, con ciò sia che la Grecia terrebbe quasi il pregio de la forma antica, se ella non si avesse lasciata privare de le reliquie de le sue scolture".

${ }^{86}$ BAROCCHI Paola. Scritti D'Arte del Cinquecento. Milano, Napoli: Riccardo Ricciardi Editore, Tomo II, p. 2354. Curador das obras de Bembo, Dolce faz citação quase idêntica à obra do religioso, e toma-o como autoridade para reafirmar seu preceito ao pintor de imitar obras antigas. DOLCE, Lodovico, op. cit., p. 146: "[...] non meno per testimonio de' poeti e scrittori antichi che per quello che di leggeri si può conoscere dalla eccellenza di quelle poche statue che ci sono state lasciate dalle ingiurie del tempo e delle nazioni nimiche, possiamo giudicar che fossero mirabilissimi". Vide trecho na obra de Bembo, citado por BAROCCHI, Paola, op. cit., p. 1535: "Questa città [Rome], la quale per le sue molte e riverende reliquie, infino a questo dì a noi dalla ingiuria delle nimiche nazioni e del tempo, non leggier nimico, lasciate, più che per li sette colli, sopra $\mathrm{i}$ qualli ancor siede, sé Roma essere subitamente dimostra a chi la mira, vede tutto il giorno a sé venire molti artefice di vicine e di lontane parti, i qualli le belle antiche figure di marmo e talor di rame, che o sparse per tutta lei qua e là giacciono o sono publicamente e privatamente guardate e tenute care, e gli archi e le terme e $\mathrm{i}$ teatri e gli altri diversi edificii, che in alguna loro parte sono in piè, com istudio cercando, nel picciolo spazio delle loro carte o cere la forma di quelli rapportano, e poscia, quando a fare essi alcuna nuova opera intendono, mirano in quelli essempi, e di rassomigliarli col loro artifício procacciando, tanto più sé dovere essere della loro fática lodati si credono, quanto essi più alle antiche cose fanno per somiglianza ravicinare le 
e suas obras. Bembo ${ }^{87}$ foi influência relevante para Lodovico Dolce no tocante às suas considerações sobre a estatuária antiga e ao próprio conceito de mimesis. Sua figura marcante será discutida ao final do capítulo.

A referência à Antiguidade é preponderante no tratado de Dolce, porque é concebida por ele como razão primeira para defender o sistema de proporção clássica da figuração presente nas obras de Ticiano, em contraposição à representação quase grotesca dos nus de Michelangelo, criados para o "Juízo Final” e pintados na Capela Sistina.

Discorrendo ainda sobre a questão da mimesis, Luigi Grassi observou que após Platão e Aristóteles, o conceito de imitação sofreu mudanças semânticas em seu percurso histórico, tomando dois caminhos contraditórios. ${ }^{\mathbf{8 8}}$ No primeiro momento, a imitação similar da natureza realizada pelo pintor criava uma ilusão do real, por estar firmemente calcada nas formas que se apresentavam à vista. No segundo, a imitação passou a realizar uma correção das imperfeições encontradas nas formas naturais, pressupondo uma superação da natureza. Por conseguinte, o procedimento da imitação elevou-se de uma simples representação presa ao real, para configurar-se como modelo de idealização na mente do artista. Pino e Dolce apresentam estes dois momentos. Leonardo já havia salientado o fato da pintura produzir simulacros da natureza operando ilusões nos observadores. Em Pino há uma ênfase maior na primeira instância citada por Grassi, da pintura enquanto ilusão. Segundo ele, a pintura imita a natureza com tal veracidade que engana até mesmo homens e animais. ${ }^{89}$ Trechos tirados de anedotas de Plínio, o Velho, ilustram seu argumento, como a história de Pôncio apaixonado por uma imagem de

loro nuove; perciò che sanno e veggono che quelle antiche più alla perfezion dell'arte s'accostano, che le fatte da indi innanzi”.

${ }^{87}$ A figura de Bembo será melhor exposta no capítulo III.

${ }^{88}$ GRASSI, Luigi e PEPE, Mario. Dizionario dei Termini Artistici. Tea Editore. pp. 403-404.

${ }^{89}$ PINO, Paolo, op. cit., p. 10. "Con tal arte si sono ingannati gli animali. Et chi può negare, che sovente gli huomini non si siano ingannati, tenendo al primo sguardo l'imagini dipinte per vive?" Pino aqui dialoga com Leonardo que, mesmo ciente de que a pintura não resulta unicamente da imitação literal da natureza, ainda assim reconhece a necessidade do pintor de imitar as coisas naturais e a força do caráter ilusório que a pintura produz. Cf. Anexo, p. 30. LEONARDO, op. cit., p. 8: “[...] ed il pittore per sè senza aiuto di scienza o d'altri mezzi va immediate alla imitazione di esse opere di natura. Com questa si muovono gli amanti verso i simulacri della cosa amata a parlare colle imitate pitture; com questa si muovono i popoli con infervorati voti a ricercare i simulacri degl'iddii [...] Com questa s'ingannano gli animali: già vid'io uma pittura che ingannava il cane mediante la similitudine del suo padrone, allá quale esso cane facea grandíssima festa; e similmente ho visto i cani abbaiare, e voler mordere i cani dipinti; ed una scimmia fare infinite pazzie contro ad un'altra scimmia dipinta. Ho veduto la rondine volare e posarsi sopra i ferri dipinti che sportano fuori delle finestre degli edifizi; tutte operazioni del pittore maravigliosissime". 
Helena, ${ }^{90}$ das uvas de Zêuxis bicadas pelos pássaros, ${ }^{91}$ e o lençol transparente de Parrásio, parecendo ocultar pessoas. ${ }^{\mathbf{9 2}}$ Por outro lado, Pino observa que, não basta unicamente retratar o natural. Para criar a imagem de uma bela mulher é preciso que, ao imitar a natureza, o pintor recolha dela as melhores partes para compor um padrão de beleza. Este paradigma não se encontra na natureza, porém resulta de uma idéia que está além dela, e que, por meio de um esboço pré-concebido, torna-se uma "representação mental" no intelecto do pintor. ${ }^{93}$ Zêuxis e as cinco virgens dos Crotonienses são o modelo e exemplo a perseguir. ${ }^{94}$ Como vimos acima, em Dolce encontramos os mesmos argumentos expostos por Pino no tocante aos três caminhos do conceito de imitação, ultrapassando-o unicamente pelo fato de aconselhar o pintor a aperfeiçoar sua obra pelo estudo da estátuaria antiga. Estes três caminhos da imitação, conforme discutidos pelos autores, tocam nos conceitos aristotélicos de "verdadeiro" e "verossímil" e no conceito de Idea platônico. A primeira via, imitação similar das coisas naturais, está ligada aos elementos que compõem a natureza com suas perfeições e acidentes, ou seja, aos acontecimentos, histórias, fatos que se apresentam diante dos olhos, correspondendo ao que é o "verdadeiro". A segunda via, imitação por superação, consiste no imitar não os fatos verdadeiros, porém como deveriam ser, ou aqueles que seriam plausíveis de acontecer, ${ }^{\mathbf{9 5}}$ no âmbito do verossímil ou do

\footnotetext{
${ }^{90}$ Idem, ibidem, p. 14: "Non so dove à tempi nostri si trovasse un pittore, che con una pittura accendesse il cuor de um huomo di libidine, come Poncio, Legato de Caio Imperatore (per quanto dice Plinio) ch'infiammatosi d'uma Helena dipinta, tentò più meggi per portarsela seco, ma essendo la pittura in muro, ciascuna inventione fu debole". Cf. Anexo, p. 42-43.

${ }^{91}$ Idem, ibidem: “[...] e Zeusi, che dipinse l'uve tanto simili alle proprie, che gli augelli volavano, à quelle credendo mangiarsele". Cf. Anexo, p. 43.

${ }^{92}$ Idem, ibidem: "Degno di più Honorato preggio fu Parasio, che dipinse un panno bianco in um quadro, sotto il qual accenò esservi certe figure, e Zeusi, suo concorrente, scintilando anchor nella gloria acquistata per l'uve, stimolava Parasio, che facesse scoprire il quadro, al che rispose Parasio, scoprilo da te stesso. Zeusi, cupido di vedere l'opra, che parea e non era, accostatosi alla tavola, diede di mano nel velo dipinto, ond'egli confessò esser vinto dall'ingeniosità del rivale". Cf. Anexo, p. 43.

${ }_{93}$ A imagem que se forma na mente do artífice expõe a identificação operada por Cícero, entre a "Idéia platônica" e a "representação artística". A perfeição que o artífice busca, não encontra-se na natureza, nem em um mundo além dela, constitui-se gradualmente enquanto imagem em seu interior.

${ }^{94}$ PINO, Paolo, op. cit., p. 4-5: "Et per non incorrere nell'imperfettione, imitate Zeusi, che volendo apresso li Crotoniati dipignere una Venere, elesse tra tutte le giovanette della città cinque vergini, la beltà delle quali soppliva all'integrità della sua Venere, raccogliendo da uma di quelle gli occhi, dall'altra la boca, e dall'altra il petto e in tal guisa reduceva a perfettione l'opera sua". Cf. Anexo, p. 9-10.

${ }^{95} \mathrm{Ou}$, ainda, fatos nos quais se acredita que poderiam acontecer. Nesse sentido, o "verossímil" estaria muito mais vinculado a uma crença, do que propriamente à realidade.
} 
necessário, seguindo a lei de verossimilhança e unidade de ação. ${ }^{96}$ Estas categorias teriam a tarefa de imprimir coerência, disciplina e ordem naquele "verdadeiro" da natureza que não o apresenta. ${ }^{97}$ Quanto à noção da Idea, na medida em que o pintor supera a natureza, corrigindo-lhe os defeitos ou acidentes, elencando as melhores partes para compor sua obra, ele está na verdade procurando um paradigma-forma-idéia que está além do mundo natural, o que revela suas imperfeições. Foi justamente esta uma das razões pelas quais Platão imputou às "artes da imitação" o papel de simulacros, uma vez que ao "corrigirem" a natureza, elas deformariam o "real", deixando de ser verdadeiras para simularem algo que não existe. ${ }^{98}$ Porém, se para Platão o mundo natural nada mais é do que uma cópia do mundo perfeito das Idéias, que está além dele, foi Cícero quem observou não estar a idea, num lugar intangível e nem podendo ser alcançada pela experiência, mas assim, encontrando-se somente no espírito do artífice.

Ainda de acordo com Grassi, estes dois momentos descrevem duas elaborações platônico-aristotélicas do conceito de imitação, significantes nos tratados de arte do século XVI, a distinção entre ritrarre e imitare, que será melhor argumentada por Vincenzio Danti em seu Trattato delle perfette proporzioni, publicado em 1567. No termo ritrarre, o pintor representa as coisas "enquanto são", reconhecendo-as como perfeitas. No imitare, o artista, para atingir a perfeição, imitaria as coisas como elas "deveriam ser", corrigindo as imperfeições naturais. Grassi afirma que estes dois termos formam um código interpretativo. Assim, o ritrarre referir-se-ia às coisas vistas, por si mesmas, com toda perfeição, o imitare, significaria representar uma coisa não somente do modo como outros possam ver nela a coisa imitada, em sua imperfeição, mas fazê-la como ela teria de ser em

\footnotetext{
${ }^{96}$ Quanto ao preceito aristotélico da "unidade de ação" referida à pintura nesses tratados, a representação da história narrada pelo pintor deveria ser feita de tal modo que todos os elementos pictóricos estivessem simultaneamente em função de expressar uma particular ação dramática, ocorrida num único espaço de tempo. ${ }^{97}$ GRASSI, Luigi. Teorici e Storia della Critica d'Arte. Parte Prima - Dall'Antichità a tutto il Cinquecento com due saggi introduttivi. Roma: Multigrafica Editrice, 1970, p. 184: "Imitazione è, dunque, nel Cinquecento più che mai l'equivalente del 'verosimile' aristotélico. Sembra talora che 'imitare' voglia semplicemente dire 'rappresentare' le cose quali sono: come quando il Dolce afferma che il pittore che più si avvicina alla natura "è più perfetto Maestro". Ma al di là delle differenze di significato che la parola imitazione poteva assumere presso i diversi autori, resta ben ferma la comune esigenza a distinguere, per così dire, tra uma rappresentazione oggettiva del vero ed uma imitazione ideale della natura, possibile nel riferimento della natura stessa, così come si presenta, ad un principio universale superiore, o Idea del Bello".

${ }^{98}$ É válido relembrar a história da estátua de Atenas construída por Fídias, contendo proporções inexatas. Quando observada no nível do chão, as deformações era visíveis. Ao ser colocada na altura exata para a qual
} 
toda sua perfeição. ${ }^{99} \mathrm{~A}$ imitação seria, nesse sentido, um procedimento por meio do qual o pintor conceberia sua obra buscando corrigir imperfeições e acidentes encontrados nas obras da natureza, representando-as na pintura de modo perfeito.

São pertinentes ainda a estes dois momentos da imitação, os argumentos colocados por Platão no Sofista, onde ele contrapõe "imitação icástica" (em relação às coisas que se encontram na natureza) e "imitação fantástica" (onde o pintor corrige com seu engenho e invenção, os defeitos da natureza). Conceitos estes que Gregorio Comanini vai retomar em seu tratado Il Figino ovvero del fine della pittura, de 1591.

Retornando a Pietro Bembo, é preciso salientar a importância de sua figura para a Itália daquele período no que diz respeito às discussões filológicas da língua italiana no processo de construção do idioma, como também apontar (como já mencionado em parágrafos anteriores) a profunda influência que exerceu sobre Dolce. Bembo (1470-1547) foi poeta, humanista erudito e cardeal. Filho de nobre embaixador veneziano, recebeu rigorosa e cosmopolita educação. Aos vinte anos escrevia em fluente latim, expressava-se corretamente no florentino, vindo a adquirir nos anos posteriores conhecimento do idioma grego. Publicou em 1525, a obra Prose della volgar língua, através da qual formalizou a completa expressão de suas doutrinas lingüísticas.

As epístolas em forma de pequenos tratados que manteve com Giovanfrancesco Pico della Mirandola (1469-1533), sobrinho do célebre Giovanni Pico (1463-1494) sobre a imitação, exerceram, segundo alguns estudiosos, grande influência nos tratadistas das artes figurativas. ${ }^{100}$ Em seu princípio de teoria lingüística, Pietro Bembo defendeu a premissa de que o idioma italiano em formação deveria resultar do entrelaçamento de duas raízes, uma clássica e outra moderna. Para tanto, os paradigmas que serviriam de modelo para imitação

foi encomendada, as proporções eram corrigidas. O exemplo de Fídias talvez tivesse dado a Platão argumentos para refutar as artes da imitação.

${ }^{99}$ Sobre esta diferença entre o "imitare" e o "ritrarre" que originará a palavra "ritratto", poderíamos considerar a contraposição entre pintor e poeta feita por G. Fracastoro, em seu "Naugerius sive de Poetica Dialogus", de 1555: "Se gli altri prendono in considerazione il singolare per se stesso, e invece il Poeta l'universale, gli altri sono come simili a quel pittore che imita il volto e le altre membra come sono nella stessa cosa. Il Poeta invece deve essere assomigliato a colui che non vuole imitare questa cosa o quella, come sono per caso e coi molti difetti che esse hanno in sé, ma, avendo contemplato l'universale e la belissima idea del suo artefice, fa la cosa come converrebbe che fosse". Cf. GRASSI, Luigi. Teorici e Storia della Critica D'Arte. Roma: Multigrafica Editrice, 1970, pp. 183-184. 
deveriam ser um único para cada categoria. Quanto aos clássicos, a língua deveria estruturar-se a partir dos escritos de Cícero. Em se tratando de modernos, os modelos a serem imitados recairiam nos escritores do século XIV, Boccaccio no tocante à prosa e Petrarca em relação à poesia.

A resposta enviada por Giovanfrancesco Pico a Bembo, datada de 19 de setembro de 1512, expõe a argumentação em dois momentos: no primeiro plano retoma Aristóteles ao reafirmar que todo homem é por natureza prediposto à imitação, em segundo, e de modo simultâneo, estabelece um diálogo com o platonismo de Marsilio Ficino, declarando que está inserida na alma humana uma certa tendência ou propensão ao procedimento da escolha. Pico assevera que, desde o nascimento o homem possui em seu interior a idéia de uma linguagem correta, seja ela uma inclinação à correta expressão, tanto no falar quanto no escrever, seja uma idéia de beleza, que se traduz numa disposição à bela palavra e à bela escrita. A idéia interior de uma correta linguagem e de uma bela palavra atua no homem como guia instintivo, para que ele se lance na escolha daquilo que é correto e belo por imitar. O que não pode realizar-se plenamente no escrito de um único autor, nem mesmo num só corpo de escrituras, porém tal idéia está espalhada numa pluralidade de obras, porque a natureza não concede a um só escritor todos os seus dons. ${ }^{101}$ Giovanfrancesco apresenta então em sua epístola uma variedade de belas e corretas obras, das quais se possa

${ }^{100}$ Barocchi, Paola, op. cit., p. 1525: "Che il celebre carteggio tra il Pico e il Bembo sulla 'imitazione' (15121518), abbia avuto riflessi sugli scrittori figurativi (cfr. Battisti, E. Il concetto d'imitazione nel Cinquecento italiano), non credo si possa negare [...]".

${ }^{101}$ G. Santangelo (traduzione del latino a cura di). Le epistole "De imitatione" di Giovanfrancesco Pico della Mirandola e di Pietro Bembo. Firenze, Olschki, 1954, p. 27-28 in SABBATINO, Pasquale, op. cit., p. 29-31, nota 37: "Quegli eccellentissimi uomini antichi, infatti, non si applicavano mai all'imitazione di qualcuno in modo tale da usare le stesse parole, le stesse frasi, gli stessi periodi, quase rimanessero degli eterni bambini, quase fossero da considerare meno indipendenti degli uccelli, per i quali, condotti fuori dal nido dai genitori, è sufficiente che li abbiano visti volare ter o quattro volte. I rinomati antichi prendevano da ciascuno quanto sembrava loro sufficiente per costruire o per ornare la frase: e ciò che tuttavia imitavano era affine alla loro natura o pertinente all'argomento di cui si trattava; così anche Celso e Columella, chiari, eleganti, concisi e di buon gusto: in uno tuttavia straordinaria eleganza, nell'altro forse più numerosi ornamenti; nondimento in essi tu non scorgerai alcuna imitazione o certamente solo una piccola imitazione: ciascuno seguiva il genio e l'inclinazione della própria natura. [...] Pertanto, essendo insita nel nostro animo una idea, una specie di seme, dalla cui forza siamo spinti a intraprendere qualche attività e come condotti per mano, e siamo allontanati da alcune altre, occorre favorirla anzi che contrastarla, attaccarsi ad essa anzi che allontanarsene; infatti la natura stessa, preoccupata della nostra felicita, non ci dà niente che sia affatto privo di valore oppurre danoso. Pertanto insieme alle altre facoltà, la natura instilla in noi anche l'idea del linguaggio corretto e dona alla nostra mente l'immagine di quella bellezza, alla quale guardiamo quando giudichiamo sia il nostro linguaggio, sia quello degli altri. Infatti nessuno, finora, è riuscito a raggiungere la perfezione completa, così che anche in 
extrair as virtudes dos escritores, para compor um só corpo de escritos que sirva à idéia inserida no ânimo. Opera-se então no âmbito das letras o mesmo procedimento utilizado por Zêuxis na pintura, o qual recolheu e concentrou na beleza do corpo de Helena, as belezas parciais dos corpos singulares das virgens de Crotona na tentativa de imitar, com o auxílio da natureza, a idéia que levava em seu interior. ${ }^{102}$ A busca da perfeita beleza da imagem de Helena segundo o método de Zêuxis, equipara-se à atitude do escritor, que tem por norma também o imitar de forma eclética todos os excelentes escritores, com o objetivo preciso de concretizar a idéia do belo e correto escrever que cada um guarda dentro de si. ${ }^{\mathbf{1 0 3}}$

Pietro Bembo, por sua vez, em sua epístola de $1^{\circ}$. de maio de 1513 , desmonta, fragmento por fragmento, o raciocínio de Pico, revirando seus argumentos. Primeiramente, ele afirma que até poderia vir a acolher a proposta de seu interlocutor sobre a imitação de múltiplos paradigmas, contudo, levando em conta que fossem considerados bons escritores, somente aqueles que estivessem em par de igualdade no tocante à nobreza de estilo e elegância em termos de escrita, aspectos de suma importância na visão de Bembo. Frente à multiplicidade de escritores e aos diversos níveis em que se posicionam seus escritos, dever-se-ia no caso de escolher um modelo para imitação, de optar pelo ótimo exemplar. Em sua opinião, Cícero seria o modelo em se tratando da prosa latina e Virgílio, da poesia heróica, de modo a alçá-los ao paradigma totalizador, transformando em próprias as partes singulares da escrita imitando-as em toda sua forma. Como ensina o próprio Cícero no $D e$

ciò si possa dire che nulla è del tutto buono; poichè la natura non ha mai dato i suoi doni a uno solo, ma a tutti senza eccezione, ed è próprio questa varietà che costituisce nell'insieme la bellezza di tutto l'universo [...]".

${ }^{102}$ Idem, ibidem, in SABBATINO, Pasquale, op. cit., p. 29-31, nota 37: "O reputi forse che invano quel saggio pittore ritenne di non poter trovare in un sol corpo femminile tutte le bellezze di cui aveva bisogno? E reputi che invano un oratore molto avveduto, seguendo la sua attività, andò anche ben oltre il suo giudizio? Egli, per rappresentare quell'immagine di un bellissimo corpo dell'eloquenza, scelse tutti gli uomini insigni per facondia, mentre Zeusi selezionò soltanto cinque fanciulle di Crotone famose per la loro bellezza; e non confidando abbastanza in essi, ritenne la stessa bellezza o l'ideale perfetto dell'eloquenza degno soltanto di imitazione e non legato assolutamente a nessuno. Pertanto dobbiamo imitare quella perfetta facoltà de dire che certamente abbiano nell'animo, com la quale possiamo anche valutare pregi e difetti del discorso nostro o degli altri; sia che la stessa Idea sia del tutto innata e perfetta fin dall'origine, sia che essa si sia perfezionata col passar del tempo, mediante lo studio di molti scrittori".

${ }^{103}$ Idem, ibidem, p. 67-68, in SABBATINO, Pasquale, op. cit., p. 31, nota 41: "(Quindi dobbiamo seguire l'istinto próprio dell'animo e l'inclinazione naturale e innata, poi creare, per così dire, um solo corpo con le varie virtù degli altri; [...] così Zeusi si servì di cinque fanciulle, non di una sola, per dipingere l'immagine nel tempio di Crotone, poiché non si potevano trovare in solo corpo quegli elementi che rappresentano in assoluto un'eccellente bellezza)". 
Oratore, II, obra de sua maturidade, somente através deste procedimento o estilo do paradigma pode vir a ser o estilo do imitador. ${ }^{104}$

Em conformidade às palavras de Sabbatino, de acordo com Bembo a escolha de uma multiplicidade de modelos a serem imitados conduziria o escritor ao ecletismo e ao heterogêneo e o exporia a graves riscos, justamente pelo fato de que, a seu ver, a idéia de uma bela e correta escrita não é inata ao homem como defende Pico, mas pode ser conquistada e formulada depois de uma longa fadiga de leitura dos textos antigos. Mais que uma idéia do bom escrever há no homem a possibilidade de apreender uma cultura por meio da escrita, que está diretamente ligada ao exercício contínuo sobre os livros, com o objetivo de aproximar a escrita individual à idéia do bom e perfeito escrever, que existe unicamente em Deus, semelhante à idéia de justiça ou de outra virtude. ${ }^{105}$

104 Idem, ibidem, p. 45-46, in SABBATINO, Pasquale, op. cit., p. 33, nota 43: “(L'imitazione, in quanto abbraccia tutto il modello, deve essere ricavata da ciò che è imitato: come potrebbe esserci qualche imitazione, se non ci fosse um modello? Infatti l'imitare, di cui parliamo, non è che il trasferire nei tuoi scritti qualcosa di símile allo stile altrui ed il possedere nello scrivere quasi lo stesso temperamento di chi ci si propone d'imitare. Ma ritorno al punto in cui tu dici che bisogna imitare tutti i buoni scrittori. Ti chiedo nuovamente se tu vuoi che noi imitiamo tutti i buoni scrittori, così che di ognuno di essi esprimiamo tutto quanto il modo di scrivere; oppure ritieni che sia sufficiente il derivare da ciascuno soltanto quell'aspetto di stile in cui ognuno è stato considerato particolarmente valente: e così delle molte parti delle forme, nelle quali si sono espressi moltissimi altri, elaborate un solo modo di sui servirci? Vedi tu in qual modo preferisci che venga inteso questo tuo dogma. Ma non è da ritenere che tu possa propendere per la prima ipotesi. Infatti che cosa ci può essere di più assurdo che voler riprodurre e contenere in una sola forma e specie di scrittura tutte quelle forme e specie di scrivere, diverse certamente e spesso molto differenti tra loro, fornite di tutte le loro parti e membra, che molti scrittori hanno conseguito? Sarebbe come se tu pensassi che nell'edificare un solo palazzo si potessero riprodurre completamente molti modelli di palazzi di vari stili. Se poi tu dirai di propendere per la seconda ipotesi, obietto che in primo luogo non è certamente imitare, quando tu scegli una sola parte tra le moltissime che costituiscono lo stile dei singoli autori; e quando più spesso avrai fatto ciò, potrai attingere da molti e creare così un tuo stile. Piuttosto questo modo di fare bisogna chiamarlo scegliere o, se si vuole, anche mendicare: infatti gli uomini si abituarono a trascorrere la loro vita mendicando il vitto, in modo da chiedere non ad uno solo, ma a molti, ciò che è necessário al loro vivere. L'imitazione, poi, abbraccia tutta la forma dello scritto imitato e richiede che siano considerate tutte le singole parti; implica tutta la struttura e la sostanza dello stile. Infatti né è da considerare imitatore di Sallustio colui che, conseguita la brevità di Sallustio, la metta assieme a parole arcaiche o popolari e ad uma struttura anche priva di simmetria; né colui il quale, nel raccontare gli avvenimenti di Giulio Cesare, há manifestato misura, ma nell'espressione ha usato um linguaggio del tutto rude, potrà per ciò essere detto degno imitatore di Cesare. Chi vuol meritarsi il nome di imitatore ed essere ritenuto da me degno di quel nome, deve riprodurre tutto lo stile del suo modello).

${ }^{105}$ Idem, ibidem, p. 42-43, in SABBATINO, Pasquale, op. cit., p. 34, nota 44: “(Del mio animo, in verità, tanto ti posso affermare, che in esso nessuna forma di stile, nessuna immagine della scrittura ho visto prima che io stesso l'abbia costruita con la mente e con il pensiero, leggendo i libri degli antichi, nel corso di molti anni, con molte fatiche e con lunga pratica ed esercizio: a ciò ora io mi rivolgo, dovendo scrivere qualcosa; e vedo quase con gli occhi, così con il pensiero, quello che serve per produrre uno scritto, da cui io attingo. Prima che io fossi fortemente versato in quei pensieri di cui parlo, guardavo in verità nel mio animo non di meno certamente, e cercavo, come da uno specchio, una qualche immagine, dalla quale prendere e formare ciò che volevo. Ma non vi era nessuna immagine, non mi si offriva niente, niente scorgevo. Pertanto, se per 
Para Sabbatino, o que se depreende da carta de Bembo é que a cultura da escrita tem o propósito de servir como introdução ao desenvolvimento da individualização e escolha do modelo, que possibilita o imitar e emular ao mesmo tempo, através de um constante empenho de superação. ${ }^{106}$ Estabelecendo uma analogia, Bembo defronta-se também nesses mesmos anos com o problema do italiano vulgar, propondo uma solução homogênea àquela data à questão do idioma latino, na qual defende o princípio de uma dignidade igual para as duas línguas. ${ }^{107}$

A contenda sobre a imitação entre Pico e Bembo não passou despercebida por Lodovico Dolce, que a refletiu em seu tratado. Lembramos que Dolce dominava o latim e havia sido curador da obra impressa de Pietro Bembo, de modo que, certamente havia tido acesso ao epistolário trocado entre os dois humanistas eruditos no período de 1512 a 1518 . Assim, ao conceber seu Dialogo, ele transpôs aspectos do raciocínio e dos argumentos contidos nas epístolas que se destinavam à constituição do idioma italiano, para a discussão do ofício do pintor, com o intuito de equiparar a arte figurativa à bela letra.

Como já mencionado em parágrafos anteriores e na confluência com outras de suas fontes como Horácio, Cícero, Quintiliano e Vasari, uma das características marcantes do tratado de Dolce encontra-se no preceito ao pintor de tomar além da própria natureza outro modelo por imitação, no caso, a estatuária antiga, ou o conjunto de obras antigas que continham por único paradigma o cânone de proporção de Policleto, o qual, em sua opinião, representava toda a perfeição da arte. Nesta sua norma de seguir um único modelo

qualcosa usavo la penna, se intraprendevo qualcosa, non secondo una norma, non secondo il mio parere erro condotto dove volevo, ma a caso e con incostanza: non mi regolava nessuna di quelle idee, che tu ricordi. Né d'altra parte ignoro che tu, dicendo ciò, riporti il pensiero dei Platonici: questi riconducono a divine rappresentazioni e immagini le cose insigni ed eccellenti che sono o in qualche modo possono essere in natura. E anch'io certo la penso così, che próprio in Dio, autore e creatore del mondo e di tutte le cose, esista senza dubbio una certa idea divina del retto scrivere, alla quale niente manca, del tutto perfetta, come quella della giustizia, della temperanza e delle altre virtù. Senofonte, Demostene e fra gli altri lo stesso Platone, e poi Crasso, Antonio e Giulio, e più di tutti Cicerone, guardavano ad essa, con tutta la forza del loro pensiero, quando dettavano o scrivevano qualcosa, e indirizzavano lo stile e il pensiero all'immagine di quella idea che avevano concepito nella mente. Ritengo che anche noi dobbiamo comportarci allo stesso modo e dobbiamo cercare a tutti i costi di avvicinarci, per quanto è possibile, con i nostri scritti e quella idea).

${ }^{106}$ Idem, ibidem, p. 57, in SABBATINO, Pasquale, op. cit., p. 35, nota 45: "(l'emulazione sia sempre congiunta all'imitazione)".

${ }^{107}$ Idem, ibidem, p. 53, in SABBATINO, Pasquale, op. cit., p. 35, nota 46: "(Anch'io ho composto alcune cose in volgare, in prosa e in versi, e ho profuso un maggiore impegno nella scrittura volgare, perché, venuto quasi meno l'uso corretto e proprio, in quella lingua già da molti si componeva in modo tanto scorretto da sembrare che, se qualcuno non le avesse dato soccorso, sarebbe caduta così in basso da giacere per lunghissimo tempo senza onore, senza splendore, senza alcuna eleganza e dignità)". 
aproxima-se além daquelas outras fontes, igualmente do raciocínio de Bembo em detrimento a Pico que defendia a pluralidade de modelos no processo de imitação do escritor, ratificando sua proposição com o exemplo de Zêuxis e das virgens de Crotona, transferindo-o para o âmbito das letras. Conforme dito acima, Bembo até acolheria tal idéia de uma multiplicidade de modelos, desde que todos se equivalessem num grau de excelência em termos de nobreza e elegância de estilo.

Quanto à pintura, da mesma maneira Dolce até propõe ao pintor fazer uso do procedimento de Zêuxis, selecionando as partes mais belas da natureza para compor sua obra. Contudo, entre as que se lhe apresentam, ele deve escolher a de maior perfeição, uma vez que a natureza não concentra a beleza perfeita num só corpo, porém a dissemina através de pequenas porções em cada um deles. Segundo Dolce, a idéia de uma beleza perfeita, tanto quanto para Bembo, a idéia de bela e correta escrita, não é talento inato ao homem, mas se constrói em seu interior resultando de muito trabalho e longa fadiga num intenso processo de estudo, busca e maturação.

Em uma mesma instância, tanto para Bembo quanto para Dolce, o procedimento da imitação, seja do escritor com seu modelo literário, seja do pintor com a natureza, deve caminhar lado a lado com a emulação, num jogo do imitar-rivalizar, cujo resultado de todo o processo culmina na superação do modelo imitado. Assim, para Dolce, no percurso de imitação da natureza o pintor deve procurar ultrapassar seus limites e rivalizar com ela, superando-a, para atingir na representação da figura humana, que significava, a seu ver, a parte mais importante da obra pictórica, a beleza perfeita.

$* * *$

Capítulo II

Os Tratados em sua relação com a Arte Retórica 
Tendo surgido há mais de dois mil e quinhentos anos atrás, a Arte Retórica difundiu sua fortuna crítica até o século XIX. Arte persuasiva e reconhecida como a sistematização de uma eloqüência natural, a Retórica passou a ser utilizada após o período clássico grecoromano, e, mais precisamente, no Renascimento, para nortear formas literárias, a criação artística e os processos críticos por meio dos quais as artes eram avaliadas. Durante longo tempo foi vista com certa desconfiança pelas observações que a ela dirigiu Platão no Górgias, reputando-a como artifício engenhoso e não merecedor de ser designado por uma techné ou ars. Aristóteles, por seu turno, em defesa da Retórica, caracterizou-a enquanto uma arte análoga ou a própria contrapartida da dialética. ${ }^{108}$

No tempo dos gregos estava vinculada às atividades da existência cotidiana, sendo a eloqüência um fenômeno natural e arte praticada por todas as pessoas como aptidão própria, sendo parcialmente registrada em livros retóricos. Os primeiros a compilar tal conhecimento observavam situações na vida real nas quais a eloqüência ocorria, analisavam os recursos utilizados pelos oradores, organizando argumentos e desenvolvendo-os segundo um método de ensino no qual poderiam partilhar tais habilidades. A eloqüência estava para os gregos ligada à instrução elementar e antes de sua codificação, remontava a uma tradição da cultura oral que tinha sua origem nos poemas de Homero. Aristóteles, pertencendo a uma cultura marcada pela oralidade, baseou-se nos princípios de Homero, citando-o inúmeras vezes em sua Retórica, extraindo de seus poemas e servindo-se do que a tradição legava, de exemplos discursivos e comportamentos enquanto referências históricas ou de vida contemporânea. ${ }^{109}$

Em Roma, para onde afluíram os retóricos gregos a partir do século II d.C., a Arte Retórica foi sistematizada enquanto doutrina. Porém, o discurso livre ficou restrito às regras do império, apesar de manter ainda um vínculo com os aspectos da vida ativa. Passou então a ser definida como uma parte daquele sistema de poder através da qual oradores e políticos romanos reivindicavam a habilidade de tal arte para o objetivo de proteger o estado. Surgem nesse período as muitas obras de Cícero como a Rhetorica ad Herenium, De Inventione, De

\footnotetext{
${ }^{108}$ VICKERS, Brian. In Defense of Rhetoric. London: Oxford University Press, 2002, p. VII.

${ }^{109}$ Idem, ibidem, p. 1-3.
} 
oratore, Brutus e de Quintiliano, as Instituições Oratórias, as quais serviram de veículos de transmissão da cultura grega a Roma. ${ }^{110}$

Os romanos transformaram essa antiga arte do discurso num conhecimento mais sistemático do que os gregos, acrescentando porém muito pouco ao seu corpus original. Contudo, apesar da Retórica afetar muitas áreas da vida e literatura romana, ela nunca se tornou uma conexão orgânica entre o ensino e a atividade adulta da política e leis, como havia sido na Grécia. Na medida em que todos os cidadãos gregos podiam exercer o direito de se expressar em benefício próprio, a oratória em Roma era praticada em locais específicos, como fórum, senado e as assembléias e exercido principalmente por um pequeno número de oradores altamente habilitados que possuíam o domínio de técnicas e regras de tal arte. ${ }^{111}$

$\mathrm{Na}$ Idade Média houve um colapso na transmissão da tradição retórica antiga, pois a maior parte dos textos sobre esta arte desapareceu, ou então sobreviveu de forma danificada e fragmentada. Os manuscritos que restaram restringiram-se aos manuais de doutrina prática, como alguns de Cícero e Quintiliano. Apesar de muitos comentários terem sido construídos a partir dos poucos textos descobertos, a circulação de tais estudos ocorria de maneira eventual e muitos escritores medievais tinham acesso somente a uma pequena parte do conhecimento. À fragmentação dos manuscritos seguia-se de maneira óbvia o fracionamento e perda de seu conteúdo original. Se havia já esta grave problemática dos textos retóricos antigos chegarem ao Medievo parcialmente destruídos, por outro, os poucos estudiosos que tinham acesso a tal saber pulverizaram o conhecimento transmitido, transformando-o, segundo seus próprios parâmetros e necessidades. Assim, a Retórica passou por consideráveis mudanças, tornando-se, por fim, disciplina nas universidades e unindo-se à dialética e à gramática e formando o que os teóricos medievais denominaram Trivium. ${ }^{\mathbf{1 1 2}}$ E como tal ensinamento, a Arte Retórica impulsionou a criação poética segundo sua normativa.

\footnotetext{
${ }^{110}$ Idem, ibidem, p. 8.

${ }^{111}$ Idem, ibidem, p. 12.

${ }^{112}$ Idem, ibidem, p. 215-217.
} 
Após o período de decomposição da forma e conteúdo a que esteve sujeita a Retórica na Idade Média, a grande realização do Renascimento foi a tarefa de promover sua reintegração segundo idênticos parâmetros com os quais os antigos a tinham concebido. Graças à investigação de humanistas, foram descobertos vários manuscritos integrais que foram traduzidos, comentados e disseminados pela Itália, quando da invenção da imprensa. No período de 1508-1509, Aldo Manuzio publicou em Veneza uma popular coleção de Retores Gregos, incluindo a Retórica e a Poética, de Aristóteles, Sobre a Composição, de Dionísio de Halicarnasso, Sobre as Idéias, de Hermógenes e Sobre o Estilo, de Demétrios. ${ }^{113}$ É preciso lembrar também que ainda na metade do século XV, com a tomada de Constantinopla pelos turcos, eruditos gregos, principalmente retores, acorreram a Veneza e ali se instalaram, difundindo seu conhecimento.

A enorme difusão dos tratados retóricos propiciou o desenvolvimento de novos gêneros literários, como cartas e orações, auxiliando escritores de todos os tipos com a redação de suas obras, inclusive cientistas. Porém, a aplicação mais peculiar desse antigo saber, realizado pelos humanistas do Renascimento, concentrou-se no âmbito das artes figurativas, na qual as normas retóricas serviram de paradigma para a criação de preceitos para a pintura. Isso ocorreu mais particularmente no século XVI, quando teóricos da arte estabeleceram um vínculo entre poesia e pintura propondo para as duas artes o mesmo procedimento compositivo oriundo da Arte Retórica, com o intuito primeiro de conferir à pintura, legitimação dentro de seu meio. Criaram, assim, a doutrina do ut pictura poesis, estabelecendo uma irmandade entre ambas as artes. Nesse sentido, tanto quanto a poesia, a pintura deveria ser fundamentada segundo a Arte Retórica e também estar sujeita às suas mesmas regras, funções e objetivos. Se na Roma antiga a oratória tinha por fim despertar os afetos do público, à pintura, além do doutrinar e deleitar, caberia principalmente o incitar a comoção de seus observadores.

Conforme o exposto acima é preciso observar que somente em décadas mais recentes os estudiosos conseguiram comprovar o quanto, de um modo ou de outro, o humanismo renascentista estava essencialmente relacionado ao reflorescimento da Retórica

\footnotetext{
${ }^{113}$ Idem, ibidem, p. 255.
} 
Clássica. ${ }^{114}$ E tão grande foi a importância conferida a esta antiga arte que o humanista que não havia se ocupado com esse conhecimento não poderia ser considerado enquanto tal. Uma das conexões estudadas pelos especialistas situa-se na intensa relação entre retórica e teoria artística, ligação esta que tem sido demonstrada com maior consistência. De acordo com eles, é certo afirmar que as atitudes críticas fundamentais ocorridas no período, cujas prescrições atingiram tanto pintura como poesia, foram definidas por meio daquela tradição, e o primeiro que deu partida a este processo foi Leon Battista Alberti. ${ }^{115}$

Se enfocarmos a preeminência de Alberti no humanismo do século XV, poderemos constatar que sua vasta erudição deveu-se em grande parte ao diálogo que exerceu com a Antiguidade. ${ }^{116}$ Com respeito mais particularmente à teoria da arte, ele efetuou uma inovação ao aplicar a antiga estrutura de tratados isagógicos ao seu Da Pintura, tomando como exemplar a obra de Horácio, implementando também à essência do conteúdo do tratado, elementos da retórica clássica derivados de Cícero e Quintiliano. ${ }^{117}$

Sendo Alberti uma das fontes primárias de Pino e Dolce, poderíamos observar a constância de elementos retóricos presentes igualmente nos tratados dos autores venezianos, tanto em termos de construção do texto, quanto de argumentação das temáticas. Alberti, Pino e Dolce seguem no louvor que estabelecem para a pintura, a técnica retórica epidítica, através da qual a discussão se dá em termos de valor no que concerne ao louvor ou censura do tema proposto, e com o objetivo de demonstrar a habilidade argumentativa do autor. O que implica dizer que todos os pressupostos nos tratados tendem a se configurar numa laude à pintura e àqueles que a exercem, equiparando-a à arte que sempre fora legitimada pela Antiguidade, a poesia, em detrimento das outras artes figurativas. O gênero epidítico ou demonstrativo na Arte Retórica apresenta "as funções de louvor e de censura, tendo como caso paradigmático o discurso festivo, em honra de uma pessoa que deve ser

\footnotetext{
${ }^{114}$ Apud O’MALLEY, John. Praise and Blame in Renaissance Rome, Durham, N.C., 1979, p.5, citado por GOLDSTEIN, Carl. Rhetoric and Art History in the Italian Renaissance and Baroque. The Art Bulletin, n. 4, v. 78,1991, p. 642.

${ }^{115}$ Idem, idibem.

${ }^{116}$ É preciso salientar que, segundo Luigi Mallè "Alberti teve uma educação excepcional, primeiro sob os cuidados paternos e segundo sob a orientação de Gasparino Barzizza em Pádua". Barzizza foi um dos pioneiros do reflorescimento da Retórica na Itália. Devido a este período de aprendizado ter ocorrido em Pádua, é certo que no aprendizado de Alberti tivessem sido constantes ensinamentos de conceitos aristotélicos. Cf. ALBERTI, op. cit., p. 6.

${ }^{117}$ GOLDSTEIN, Carl, op. cit., p. 642-643.
} 
celebrada (e, portanto, louvada), pronunciado por um orador". ${ }^{118}$ É este procedimento que estes três tratadistas tomam em relação à arte pictórica.

Semelhanças entre estes autores e a arte da oratória poderiam ser propostas já a partir da estrutura tripartida de sua construção. A tripartição que os caracteriza vincula-os aos "tratados isagógicos" elaborados na Antiguidade alcançando Pino e Dolce, não só via Alberti, mas inclusive via Horácio. Os três tratados abarcam a forma isagógica quanto às suas propriedades específicas. Tais escritos representavam os princípios elementares de um ensinamento ou doutrina, e foram concebidos com o objetivo primeiro de transmiti-los às pessoas de maneira introdutória. Foram projetados inicialmente pelos filósofos Estóicos e tinham por escopo conferir estatuto teórico a um conhecimento técnico. O método deveria ser simples e didático a fim de difundir os rudimentos preliminares de alguma disciplina. E por apresentar um viés não prático, eles poderiam ser adequados a qualquer um que estivesse interessado no tema discutido, sem ser um profundo conhecedor da área, mas servindo também e inclusive àquele que exercia o ofício da disciplina referida. Nesse sentido e inerente às artes figurativas, os antigos tratados isagógicos (no caso de Alberti, cuja forma foi transposta por ele para a teoria da pintura) poderiam ser lidos tanto pelo artesão interessado em ter um conhecimento filosófico acerca de seu trabalho, como pelo observador interessado na arte, em suas linhas mais gerais. ${ }^{119}$ A característica principal desses tratados encontra-se no fato de que neles deveriam constar preponderantemente duas seções, uma dedicada a ars, e outra ao artifex. ${ }^{\mathbf{1 2 0}}$ Segundo Eudoro de Sousa, esta divisão estrutural teria por ascendência Heráclides de Ponto, que teria sido o primeiro a unir num único tratado as duas seções, sendo a poética de Horácio o exemplo mais notório deste tipo de escrito. Na obra de Aristóteles, estas duas seções estariam separadas. A ars, pertencendo à Poética, e o artifex, ao De Poetis. ${ }^{121}$

Nesse sentido, a Arte Poética de Horácio foi um exemplo dos mais notáveis dessa forma literária, porque o conteúdo de seu tratado pôde ser aplicado não somente à poesia, mas também a outras disciplinas, como música, filosofia e medicina. Estudiosos

\footnotetext{
${ }^{118}$ LAUSBERG, Heinrich. Elementos de Retórica Literária. Lisboa: Fundação Calouste Gulbenkian, 1993, p. 84.

${ }^{119}$ GILBERT, Creighton. Antique Frameworks for Renaissance Art Theory: Alberti and Pino, "Marsyas", III, 1943-45, p. 91.

${ }^{120}$ Idem, ibidem.
} 
observaram que sua epístola está sistematicamente dividida em três seções: no conteúdo poético, na técnica poética e sobre o poeta. É sabido que Horácio influenciou-se pelo escrito de um teorizador de poesia helenista de nome Neoptólemo de Pário, cujos trabalhos foram perdidos. $^{\mathbf{1 2 2}}$ Neoptólemo e Horácio aplicaram a forma do tratado isagógico à poesia, não desenvolvendo, contudo, uma estrutura funcional em seus próprios trabalhos, porém, assumindo uma convenção familiar com propósitos educacionais. ${ }^{123}$ É preciso notar que a Arte Poética de Horácio é uma das principais fontes antigas de Lodovico Dolce.

Segundo Gilbert, Alberti, seguindo os passos de Horácio, utilizou o esquema estrutural dos tratados isagógicos e o preencheu com um conteúdo não usual na Antiguidade, a teoria da pintura, com semelhante propósito que o autor latino, para fins didáticos ao pintor iniciante. Um outro autor, D. R. E. Wright, em contraposição a Gilbert e num estudo mais recente ${ }^{\mathbf{1 2 4}}$, afirmou que o plano total da obra de Alberti corresponde à estrutura das Instituições Oratórias, de Quintiliano, em suas divisões elementa, ars e artifex. Quintiliano havia estabelecido que a Arte Retórica poderia ser melhor argumentada se fosse tratada a partir desses três pontos de vista, a arte, o artífice e seu trabalho, a despeito de não ter seguido esse esquema em sua própria obra. $^{125}$

Como visto na introdução, os escritos sobre artes figurativas anteriores a Alberti eram receituários de oficina, que se atinham a questões fundamentalmente práticas do fazer artístico. As teorias expostas no Da Pintura são uma tomada de posição do autor frente às exigências que o ambiente artístico daquele momento fazia quanto à posição social do pintor, cujo ofício ele aspirava, fosse alçado à categoria de arte liberal (discussão esta, cuja amplitude culminará no desenvolvimento da doutrina do ut pictura poesis no século XVI). Nesse meio artístico, o douto Alberti, arquiteto, letrado e teórico da arte, convivia com $\operatorname{artífices}^{\mathbf{1 2 6}}$ os mais importantes de seu período, entre eles, Fillippo Brunelleschi e

\footnotetext{
${ }^{121}$ ARISTÓTELES, op. cit., p. 23.

${ }^{122}$ GILBERT, Creighton, op. cit., nota 15, p. 101. Cf. também HORÁCIO, op. cit., p. 30 a 36.

${ }^{123}$ Idem, ibidem, p. 91.

${ }^{124}$ D.R.E. Wright, "Alberti's De Pictura: Its Literary Structure and Purpose", Journal of the Warburg and Courtauld Institutes, XXXVII, 1984. In VICKERS, Brian, op. cit., p. 342 e nota 10. E também in GOLDSTEIN, Carl, op. cit., p. 643.

${ }^{125}$ VICKERS, Brian, op. cit., p. 342 e nota 10.

${ }^{126}$ Para designar o ofício daquele que exercia as artes figurativas, sempre utilizaremos ao longo do trabalho o termo "artífice", uma vez que a palavra "artista" na acepção que nossa época abarca, jamais existiu no
} 
Donatello, que fizeram do retorno à Antiguidade seu novo ponto de vista enquanto fonte de estudo e renovação da grandiosidade perdida das artes desde aqueles tempos. O perfil destes artífices intelectuais diferia completamente da geração daqueles medievais, confinados à sua oficina, cujo trabalho era julgado mecânico. Brunelleschi foi um dos principais idealizadores da perspectiva. E Donatello realizou uma inovação escultórica com o percurso de sua obra. Se a posição deles frente à arte era inovadora, o tratado de Alberti seguia a mesma direção, havendo uma correspondência intrínseca entre as duas circunstâncias, prática e teórica.

No século XVI o estatuto profissional do pintor italiano encontrava-se já quase consolidado e legitimado, porém, no século XV, de Alberti e Leonardo, a luta ainda era premente. É nesse sentido que Alberti, ao assumir tratar de pintura por meio de elementos retóricos, princípios científicos e bases filosóficas, omitindo o aspecto técnico, comprovaria que, a partir de então, o pintor deveria gozar de outra posição. Para dar esse passo importantíssimo, Alberti tomou então por modelo uma estrutura literária antiga como fonte, o tratado isagógico, oriundo de obras às quais deveria ter tido acesso por seu domínio da língua latina. Certamente existiram escritos da Antiguidade que versavam sobre artes figurativas, mas não sobreviveram ao tempo, de modo que os termos e o conteúdo com os quais Alberti desenvolve o seu Da Pintura são inerentes e específicos de sua condição de humanista erudito, refletindo as circunstâncias e questionamentos artísticos próprios de seu período.

O Da Pintura é, tanto quanto a Arte Poética, tripartido. Em correspondência a Horácio, Alberti fraciona seu tratado em rudimentos da pintura, sobre a pintura em si e acerca do pintor, de modo a conter as duas principais partes do tratado isagógico: ars e artifex. Como mencionado acima, esta estrutura de concepção do texto direcionava-se a dois tipos de público simultaneamente, àquele que exercia de fato o ofício e ao amador. Nesse sentido, e no que diz respeito à pintura, o tratado poderia ser lido tanto pelo artesão desejoso em ser filosófico em seu trabalho como também pelo público que aspirava obter

Renascimento. Segundo Andrè Chastel, não há referências a ela nos escritos do período, e a denominação "artífice" era empregada para conceituar desde o mais simples artesão, que produzia todo tipo de artefato manualmente, como aqueles que foram se tornando de modo gradual mais intelectualizados. Cf. CHASTEL, André, in: GARIN, Eugenio. O Homem Renascentista. Cap. VII, O Artista. Lisboa: Editorial Presença, 1991, p. 171. 
maior conhecimento sobre pintura. Seria, portanto, um instrumento de aproximação entre dois grupos de pessoas com interesses diversos, que se ocupariam de um assunto sob um mesmo ponto de vista. O público amador era personificado pelos mecenas ou patronos que encomendavam obras aos artífices, cultivavam o gosto pela arte e tinham interesse em conhecer o processo de concepção artística. No caso de Horácio, os Pisões, a quem a Arte Poética, foi dedicada, eram poetas diletantes que pediram-lhe conselho de como proceder em suas composições.

Alberti é nesse momento um erudito afinado e perceptivo quanto a esta circunstância de seu período, porque redigiu seu tratado (sem alteração de conteúdo) nas duas línguas correntes, o latim dos doutos, e o idioma italiano vulgar ainda com irregularidades e em formação, mas que aos poucos invadia todas as esferas da cultura. Desse modo, o Da Pintura poderia ser lido por duas camadas distintas de pessoas. Tanto letrados, eruditos e artífices, quanto pessoas cultas da nobreza, interessadas em pintura.

Retornando à condição dos pintores, observamos que, da clausura da oficina na época medieval, estimados enquanto rudes artesãos cujo ofício era igualmente reputado como arte mecânica, eles começaram a ter de forma gradual o seu estatuto profissional elevado. Vieram aos poucos usufruir de maior contato com seus patronos que lhes solicitavam cada vez mais encargos, passando assim a freqüentar a corte. ${ }^{127}$ Se a princípio a deliberação sobre as obras cabia aos patronos de acordo com seus interesses pessoais e gostos, as decisões quanto a detalhes intelectuais e iconográficos das obras transferiram-se gradativamente para as mãos dos próprios pintores. Desse modo, o artífice veio a ser um intelectual de talentos especiais que detinha o poder sobre os procedimentos de concepção de sua obra. Ao se tornar um protegido dos líderes oficiais daquele ambiente cultural, conquistando um novo papel e freqüentando a corte junto a humanistas e poetas, ele obteve o respeito por seu ofício. O convívio, a troca de idéias e atitudes entre pintor e poeta principalmente, fez da pintura importante objeto de argumentação teórica entre os letrados. A conseqüência desses fatos é um dos aspectos que originou a elaboração da doutrina do $u t$ pictura poesis por eruditos que no século XVI, utilizando-se de recursos retóricos,

\footnotetext{
${ }^{127}$ Encontramos exemplos marcantes de artífices cortesãos. Leonardo freqüentando a corte dos Sforza, Michelangelo vivendo no mesmo ambiente que Lorenzo, o Magnífico e Rafael, convivendo com os Papas.
} 
prescreveram a intrínseca aproximação entre poesia e pintura. Entre eles inclui-se Pino e Dolce.

Na seqüência das relações de influência entre fontes e tratados, poderíamos nos voltar para o Dialogo di Pittura de Paolo Pino e estabelecer um cotejo entre ele e sua principal fonte, o Da Pintura, de Alberti.

O Dialogo assemelha-se a um tratado isagógico, porque também vem a ser dividido em três seções, de modo implícito e não evidente, sendo uma delas dedicada a ars e outra ao artifex. E, segundo, por ser didático, contendo todo um processo de doutrinação ao pintor.

Se o parâmetro de Alberti foi a obra de Horácio, o texto de Pino (como visto na introdução) tem como paradigma direto a obra do erudito florentino, apresentando no entanto algumas divergências em relação a ela, seja de ordem teórica, seja por sua estrutura dialógica. Isto talvez seja uma das carências do tratado de Alberti, que deixou de lado a tradição antiga de argumentar temáticas na forma de diálogos, para encontrar sua própria forma literária. ${ }^{128}$ Por seu turno, o tratado de Pino adequa-se àqueles termos pois suas temáticas desenrolam-se por meio da conversa de dois pintores. Na dicotomia entre beleza artística versus natural, através da qual ele exalta a beleza das mulheres venezianas, Pino estabelece um contraste dramático na posição e no caráter dos interlocutores, chegando a dispor ao longo de todo o diálogo de um tom de ironia mesclado à comicidade.

No que concerne ao tratado de Dolce, o estudo de Mark Roskill ${ }^{129}$ propõe de modo semelhante a sua tripartição, como ocorre de modo análogo com Pino e Alberti. O tratado de Dolce, no entanto, diverge em alguns aspectos das características específicas do tratado isagógico. A parte destinada a ars é também pedagógica. Porém, os argumentos sobre o artifex, que deveriam conter uma doutrina das maneiras de agir e ser de todo pintor são substituídos por um pequeno painel biográfico e, simultaneamente, encômio ao veneziano Ticiano. Segundo Roskill, o tratado tem sua divisão efetuada em dois momentos no desenrolar da conversação. No primeiro momento, e ainda numa primeira instância, com referência à essência do diálogo, encontramos: a discussão sobre a nobreza da pintura e os elementos necessários para se atingir a sua perfeição. Segundo: a citação de exemplos, tanto

${ }^{128}$ GILBERT, Creighton, op. cit., p. 93. 
antigos como modernos. Terceiro: a maestria de Ticiano e as obras por ele criadas. O segundo momento consta de uma tripartição de seções que compõem o conteúdo do tratado: a primeira parte em que os princípios e propriedades da boa pintura são expostos e elucidados, os quais são acompanhados por trechos em introduzem teoria literária e o esboço de um sistema filosófico, espalhados por argumentos discorridos entre os interlocutores. A segunda parte representaria o cotejo entre Rafael e Michelangelo, a partir de conceitos propostos na primeira seção, o que incluiria também a apreciação de outros artistas preeminentes do século XVI, salientando a grandeza de Ticiano. E a última parte, o encômio de Ticiano, enquanto grande representante da pintura veneziana, em detrimento à romana, seguido de um perfil de sua trajetória artística. Segundo Roskill, há passagens que se apresentam como pontes entre as temáticas e asseveram o caráter tripartido do diálogo.

Como observado acima, no que concerne à estrutura interna, os diálogos, objetos desta pesquisa, têm como característica comum uma analogia com as fontes com que eles dialogam, seja Alberti e Horácio, e que se fundamenta na tripartição própria dos antigos tratados isagógicos.

Outra característica inerente a todos os tratados dos séculos XV em diante, com respeito às artes figurativas, às letras, à música, é a existência de uma página encomiástica. Sendo humanistas, poetas e artífices subordinados à subvenção de nobres mecenas, representados por banqueiros, príncipes, imperadores ou papas, os escritos eram sempre dedicados a uma dessas figuras eminentes, e deviam ser redigidos num estilo extremamente refinado, erudito e primoroso, seguindo princípios da Arte Retórica. Esta página encomiástica, denominada proêmio ou exórdio, pertence também ao gênero epidítico e era dirigida ao patrono da obra com o objetivo de enaltecê-lo. Tanto Paolo Pino como Lodovico Dolce destinaram suas obras a dois nobres venezianos. Pino, a Francesco Donato, que exerceu a função de doge entre 1545 a $1553 .{ }^{\mathbf{1 3 0}}$ Dolce, a Ieronimo Loredano, também descendente de família ilustre de antigos doges da alta cúpula veneziana. ${ }^{131}$ Segundo Mark

\footnotetext{
${ }^{129}$ ROSKILL, Mark W., op. cit., p. 8.

${ }^{130}$ PINO, Paolo, op. cit., p. 2: “All'Illustrissimo Signor Francesco Donato, Prencipe di Vinegia" e "[...] ho ardito Illustrissimo Prencipe d'appendere questa mia fática agli honorati piedi di V. Serenità [...]". Cf. Anexo, p.2.

${ }^{131}$ DOLCE, Lodovico, op. cit., p. 143: "Al Magnifico e Valoroso Signor Ieronimo Loredano" e "[...] Ho sempre portato, magnifico Signor Ieronimo, e porto del continovo nel mio animo um disiderio vivíssimo di dimostrare in qualche parte l'antica mia affezione verso la nobilíssima Casa Loredana; [...]”. Cf. Anexo, p.95.
} 
Roskill, a dedicatória de Dolce é similar em tom e estrutura àquela feita por Vasari a Cosimo de Medici, na primeira edição das Vite, de $1550 .{ }^{\mathbf{1 3 2}}$

Como que seguindo os preceitos do discurso de um orador, encontramos no corpo dos tratados elementos retóricos como: exordium, captatio benevolentiae, propositio, dispositio, argumentatio, elocutio, ingenium, inventio, narratio, ornatus, etc. No caso de Pino em específico, encontramos além do encômio, uma pequena "Carta aos Leitores", onde ele expõe a captatio benevolentiae e a propositio, o que implica dizer que, ao mesmo tempo em que propõe-se a argumentar sobre pintura, Pino tece uma auto-crítica, afirmando não se considerar digno de realizar tal empresa, visto que outros homens notáveis já o haviam efetuado com maior proeminência. ${ }^{133}$ É uma maneira de captar a benevolência de seus leitores, deixando-lhes ao final da leitura de sua obra a escolha entre a censura ou o louvor. Com esta página, Pino cria um pequeno jogo retórico através do qual, por um lado, finge modéstia diminuindo-se numa condição de não meritório do tema que vai tratar, por outro, aguarda ansiosamente o reconhecimento, louvor e coroação de louros por parte de seus ouvintes. ${ }^{134}$ Nesta carta ao leitor, Pino refere-se a Aristóteles, que já havia apontado em sua Retórica a importância nos discursos judiciários do apelo aos ouvintes para se obter a indulgência quando o tema tratado pudesse resguardar uma agumentação paradoxal, difícil ou discorrida por muitos. ${ }^{135}$

\footnotetext{
${ }^{132}$ ROSKILL, Mark W., op. cit., p. 10.

${ }^{133}$ PINO, Paolo, op. cit., p. 3: "Vero è che Plinio scrisse di lei (della pittura) molte cose degne, alcune delle quali sono inserte nel presente Dialogo, e Leon Battista Alberto Fiorentino, pittore non menomo fece um trattato di pittura in língua latina, il qual è più di Mathematica, che di pittura, anchor che prometti il contrario. Et ancho Alberto Duro, molto nel disegno eccellente scrisse in tal materia, parmi che Pomponio Gaurico ne scrivi alquanto, ma costui s'istende più nella Scultura, nella Fusoria e nella Plástica, materie molto dall'arte nostra differenti". Cf. Anexo, p.3.

${ }^{134}$ Idem, ibidem: "Il perchè non mi parendo com tal prosontione, parmi degno d'alcun castigo ragionando di Pittura come pittore, deliberai tra me stesso di scriverne quanto l'intellecto mio mi comportasse, nientedimeno, ho più fiate pervertito di commettervi nell'importanza d'um tanto carico, accorgendomi esser povero d'intelligenza, e mancar di quella candidezza di stile, che richiederebbe". "[...] al fine sperando più compassione, che biasimo [...]". Et s'avviene, che diversamente questo mio trattato sia giudicato e reprobato, mi terrò degno d'oscurarmi con la morte". Cf. Anexo, p. 3-4.

${ }^{135}$ ARISTOTELE. Retorica. Introduzione di Franco Montanari. Testo critico, traduzione e note a cura di Marco Dorati. Milano, Arnoldo Mondadori Editore, 1996, p. 353: “Un'altra fonte nell'epidittica possono essere gli esordi dei discorsi giudiziari, vale a dire l'appello agli ascoltatori per ottenere indulgenza, quando il discorso riguarda um argomento paradossale o difficile o discusso da molti, come fa Cherilo: 'Ora che tutto è stato trattato [...]' Queste sono dunque le fonti degli esordi dei discorsi epidittici: lode, biasimo, esortazione, dissuasione, appello all'ascoltatore. La nota iniziale deve essere estranea o collegata al discordo".
} 
Quanto à propositio, no diálogo de Dolce é o momento em que ele se propõe a discorrer sobre o conceito de pintura e suas partes, o ofício do pintor, a comparação entre Michelangelo e Rafael, e por fim, o encômio a Ticiano. ${ }^{\mathbf{1 3 6}}$

Quanto aos temas, Pino e Dolce os argumentam com grande eloqüência (elocutio), corroborando-os por meio de exemplos extraídos de autores clássicos de reconhecido valor, as auctoritas, valendo-se assim da inventio, que é o encontrar nestes autores os argumentos próprios para desenvolver a tese proposta em seus diálogos. Pino retorna aos antigos, principalmente Vitrúvio e Plínio. Dolce, remete-se além desses dois autores, a fontes gregas e latinas, como Homero, Platão e Aristóteles, assim como Horácio, Cícero, Quintiliano, Ovídio e Terêncio. Encontramos ainda em seus diálogos, além da elocutio e inventio, a dispositio, e a argumentatio, que serve-se da inventio para se afirmar, e o ornatus, figurados pela beleza da expressão lingüística exposta por meio de ornamentos representados por figuras de linguagem, característica constante ao longo de todo o texto de ambos.

No tocante às funções retóricas, encontramos nos dois tratados o docere, o muovere e o delectare. Quanto ao docere, Pino e Dolce doutrinam seus leitores ao conceituar a pintura e mostrar-lhes quais as partes que lhe são inerentes, bem como ao expor o cânone de proporção da figura humana postulado por Vitrúvio. No tocante ao muovere, Pino em específico utiliza-se desse artifício para captar a benevolência de seus leitores, introduzindo-os ao tema que pretende discorrer em seu tratado. Por fim o delectare encontra-se nos dois diálogos, seja pela condução das próprias temáticas debatidas, seja pela eloqüência dos argumentos, ilustrados pelas narrativas de Plínio.

Semelhantemente, os diálogos apresentam os três gêneros da retórica: judicial, que tem por função acusar ou defender uma causa. Tanto Pino como Dolce abraçam a defesa da pintura enquanto a arte liberal, assegurando Dolce ser ela ainda, irmã da poesia. O deliberativo, que tem por função aconselhar e desaconselhar, no qual poderíamos mencionar todos os preceitos de conveniência e decoro aos quais devem se submeter os pintores e suas obras, assim como as prescrições de conduta moral. E o epidítico ou demonstrativo, o qual, como mencionado acima, tem por função o louvor ou a censura,

\footnotetext{
${ }^{136}$ DOLCE, Lodovico, op. cit., p. 150: "Dirò adunque primieramente quello ch'è pittura e l'ufficio del pittore, e poi, discorrendo per tutte le sue parti, nel fine verrò al paragone di costor due, et ancora vi ragionerò di alcuni altri e principalmente di Tiziano". Cf. Anexo, p.100.
} 
utilizados pelos autores quando de sua exaltação aos pintores virtuosos, e a censura a outros por suas deficiências.

Uma particularidade que especifica o diálogo de Pino em detrimento ao de Dolce é que ele faz uso de um artifício retórico em que a argumentação sobre a defesa da pintura veneziana em seus aspectos peculiares origina-se da fala do pintor florentino Fábio, e não do veneziano Lauro, o que seria mais lógico. Tal procedimento é denominado "ironia como tropo de pensamento distinguida pela dissimulação", ${ }^{137}$ o que significa expor todo o raciocínio sobre determinado tema na fala do partidário rival, no caso o pintor florentino, como a querer dar maior autenticidade e autoridade para as idéias defendidas, ao contrário do que resultaria se fossem colocadas pelo próprio pintor veneziano Lauro, não sendo assim levadas a sério pelos leitores.

A particularidade de Dolce, por sua vez, encontra-se no uso de ecfrases, recurso retórico utilizado por letrados para descrever pormenorizadamente pinturas que visem criar imagens na mente do leitor, a fim de esclarecer a teoria a que se propõem. Dolce o faz inúmeras vezes. Narra obras pictóricas de Michelangelo, Rafael e Ticiano, servindo-se delas para ilustrar principalmente sua argumentação de invenção, conveniência e decoro, (além das já mencionadas citações de autores antigos), como também para defender a tese primeira de seu diálogo, ou seja, exaltar Ticiano acima de Michelangelo.

Por último, quanto aos gêneros da elocução, os diálogos encontram seu espaço particular. Os escritos classificavam-se por uma divisão ao mesmo tempo de estilo, gêneros e posição social. A linguagem de estilo elevado destinava-se à tragédia, que discorria sobre grandes temas e seus personagens pertenciam à nobreza, sendo representado pelo genus sublime. A linguagem modesta era expressa pela comédia, onde as matérias discutidas eram baixas, e os personagens de um extrato social inferior, o genus humilis. Entre os dois,

\footnotetext{
${ }^{137}$ LAUSBERG, Heirinch, op. cit., p. 252-253: "A ironia que emprega a tática da ação usa a dissimulação e a simulação como armas do engano: quer, por conseguinte (até que se dê uma eventual alteração da situação), manter em estado definitivo, o mal-entendido. $\mathrm{O}$ sujeito falante não quer tornar conhecida a sua própria opinião partidária, pois que a situação não permitiria, apesar de tudo, uma atuação eficaz da própria opinião partidária, por meio da persuasão. Do mesmo modo, a manifestação da própria opinião partidária não cumpriria a finalidade do discurso, visto que teria, como resultado, apenas o informar o partido contrário sobre a própria opinião partidária, processo que permitiria ao partido contrário aproveitar este aumento de informação em desfavor do partido, a que pertence o sujeito falante. A ironia retórica quer ser compreendida pelo ouvinte como sentido contrário; pode obter imediatamente no ouvinte este resultado de compreensão, ou
} 
encontra-se a linguagem mediana reservada a tratados e obras didáticas, o genus medium. Gênero ao qual pertencem os diálogos de Pino e Dolce.

Nesse sentido, observamos que a tripartição dos textos segundo antigos tratados isagógicos e sua edificação com base em elementos retóricos, são aspectos que podem contribuir para a compreensão de uma teoria veneziana. Poder-se-ia afirmar que os teóricos da região Tosco-Romana, mais envolvidos com a investigação de uma teoria do conhecimento, aplicaram-se a diversos campos de estudo, principalmente das ciências, dando assim maior ênfase aos aspectos matemático-científicos em sua argumentação das artes figurativas, do que os humanistas da Itália setentrional, cujo enfoque de saber era direcionado e assentado de modo primordial em saberes filosóficos, retóricos e de ordem literária.

então pode querer jogar, durante algum tempo, com um estado passageiro de mal-entendido, ocorrendo isto através da dissimulação". 


\section{Capítulo III}

\section{Pino e Dolce partidários da doutrina do ut pictura poesis}

O cotejo que os teóricos do século XVI estabeleceram entre pintura e poesia originou-se, entre outros motivos, a partir de três necessidades primordiais: defender a pintura do papel de simulacro que Platão havia lhe imputado na Antiguidade; retirá-la do contexto de "arte mecânica" com que ela vinha sendo apreciada desde a Idade Média, atribuindo-lhe a importância de uma "arte liberal" e, conseqüentemente, por fím, alçar o artífice ao nível de homem culto e não rude artesão, legitimando um lugar mais digno para seu ofício no quadro social de seu tempo. Esta teoria começou a tomar forma principalmente a partir do terceiro decênio do século XVI, quando foram publicados na Itália vários tratados sobre arte poética que se inspiravam na obra de Aristóteles, ou faziam comentários sobre ela. Os mais significativos publicados no século XVI foram: Vida, De Arte Poética, Roma, 1527 (em verso); Bernardino Daniello, La Poética, Veneza, 1536; Robortelli, In librum Aristotelis de Arte Poética Explicationes, Florença, 1548; Girolamo Fracastoro, Naugerius sive de Poética Dialogus, Veneza 1555; Minturno, De Poeta, Veneza, 1559 e L'Arte Poética, Veneza, 1564; J.C. Scaliger, Poetices, Genebra, 1561; Castelvetro La Poética d'Aristotele, vulgarizzata et sposta,Viena, 1570; Torquato Tasso, Discorsi dell'Arte Poética, Veneza, 1587. ${ }^{1}$ A fim de estabelecer uma comparação entre pintura e poesia, os teóricos tomaram por exemplar a obra de Aristóteles e a epístola aos Pisões, de Horácio (bastante influente entre os humanistas do XVI). Assim, da obra do filósofo grego e do escritor latino extraíram as mais significativas passagens que dessem ensejo a uma relação entre as duas artes e pudessem corroborar seus argumentos, no sentido de prescrever para a pintura os mesmos procedimentos (de ordem retórica) utilizados para a concepção da poesia, criando assim a doutrina do ut pictura poesis.

De suma importância nos debates intelectuais do período, a comparação que aponta semelhanças e dessemelhanças entre as artes, pintura e poesia, ou pintura e escultura, foi temática constante nos tratados dos teóricos humanistas e um procedimento de argumentação da arte oratória. Na Arte Retórica, a comparação, juntamente com a

\footnotetext{
${ }^{1}$ LEE, Rensselaer W., op. cit., p. 205, nota 41.
} 
gradação, são duas das quatro espécies que fazem parte da amplificação. ${ }^{2}$ A comparação ${ }^{3}$ das duas artes propõe a elevação da pintura no mesmo patamar que a poesia. Nesse sentido, há um processo de gradação ${ }^{4}$ porque os autores fazem com que a pintura que sempre fora considerada inferior em relação às outras artes, pareça, por meio da comparação, tão superior quanto à poesia, e nessa equiparação o próprio valor da poesia é ainda mais engrandecido, resultando assim na amplificação do apreço de que ela já era objeto. Por sua vez, o procedimento de estabelecer a semelhança é um ornato que faz com que o argumento torne-se mais claro para o leitor. ${ }^{5}$ Dolce irá utilizar este recurso de comparação e semelhança ao estabelecer relações de superioridade e inferioridade entre os pintores Michelangelo, Rafael e Ticiano.

Se na Itália central os teóricos deram maior ênfase no vínculo da pintura com as ciências matemáticas para legitimar sua importância, teóricos setentrionais, por sua vez, por não possuírem tal gama de conhecimentos científicos, colocaram maior energia e empenho na valorização da pintura prescrevendo-lhe um laço intrínseco com a poesia, aplicando como estrutura de ligação a Arte Retórica, o que se percebe de modo implícito no tratado de Pino e está mais claramente definível no escrito de Dolce.

Apesar da primeira publicação dos manuscritos de Leonardo (que se convencionou denominar de Trattato della Pittura) ter ocorrido somente em $1651^{6}$ e o fato de sua obra não ter sido fonte de Pino e Dolce, é preciso salientar que já no século XV ele havia escrito enérgicos argumentos sobre o cotejo entre as duas artes, conferindo superioridade à pintura em relação à poesia e escultura. ${ }^{7}$ No Da Pintura, Alberti preceitua ao pintor que ele deva

\footnotetext{
${ }^{2}$ QUINTILIANO, M. Fábio. Instituições Oratórias. São Paulo: Edições Cultura, 1944, p. 81: “Contudo a quatro espécies principais vejo, se pode reduzir a Amplificação, que são: Gradação, Comparação, Raciocínio, Ajuntamento".

3 Idem, ibidem, p. 83: "Mas assim como esta Amplificação caminha gradualmente das coisas inferiores para as superiores: assim a que se faz por Comparação umas vezes toma o seu aumento da amplificação das coisas menores. Pois aumentando ela o que está abaixo, necessariamente há de engrandecer o que está acima”.

${ }^{4}$ Idem, ibidem: "De todas estas a mais forte é a Gradação, quando fazemos parecer grandes as coisas inferiores, subindo destas para as superiores, ou por um grau somente ou por muitos, e chegando por este modo não só ao máximo, mas às vezes, em certo modo, ainda acima do máximo".

${ }^{5}$ Idem, ibidem, p. 69: "Porém um dos meios mais próprios, que se tem descoberto para aclarar as coisas, são as Semelhanças: das quais umas, tendo por fim a prova se contam entre elas; outras, porém, são destinadas a pintar os objetos $[\ldots]$ "..

${ }^{6}$ BALDINI, Massimo (org.). Leonardo da Vinci, Aforismi, Novelle e Profezie, Newton Compton Editori, Roma, 1993, p. 7.

${ }^{7}$ Entre os vários teóricos que se pronunciam sobre a comparação entre as duas artes (e cada um deles apresenta uma peculiaridade) Leonardo foi quem expôs de modo mais veemente, fortes e extensos argumentos (dos quais citamos apenas alguns) para defender a superioridade da pintura em relação à poesia.
} 
tanto deleitar-se como ter familiaridade com poetas e oradores, com os quais adquiriria conhecimento a fim de compor a história de sua pintura. Segundo Alberti, poetas e oradores seriam autoridades nas quais o pintor deveria confiar para encontrar suas invenções. ${ }^{\mathbf{8}}$ Pino, num diálogo constante com Alberti e acolhendo o conselho deste último, influencia-se, como visto acima, não só pela obra de Aristóteles, como também pela Poética, de Bernardino Daniello, ${ }^{9}$ publicada em Veneza em 1536, para desenvolver alguns de seus argumentos. No que concerne a Dolce, a despeito de ter tido igualmente acesso a diversas obras poéticas do período, aproxima-se com maior veemência da Arte Poética, de Horácio, da qual havia efetuado uma tradução em sua juventude. Mas, tanto Pino quanto Dolce, são veementes ao vincular procedimentos de concepção da pintura a elementos da Arte Retórica.

Ambos os tratadistas prescrevem uma intrínseca relação entre pintura e poesia, assim como asseveram uma natureza peculiar pertencente ao pintor e ao poeta. De acordo com Pino, o pintor deve nascer com a disposição para o discernimento, denominado por ele de juízo, tanto quanto os poetas, ${ }^{\mathbf{1 0}}$ qualidade que não se pode adquirir somente com a experiência. Assim, um artífice não se torna virtuoso unicamente por meio da experiência e da prática. É necessário que ele nasça com uma natureza propícia para este ofício, de modo semelhante aos poetas. Diferentemente dos oradores, uma vez que qualquer um que possua

LEONARDO, Trattato della Pittura, Grandi Tascabili Economici Newton, Roma, p. 4, 5 e 7.: "Perchè la poesia pone le sue cose nella immaginazione di lettere, e la pittura le dà realmente fuori dell'occhio, dal quale occhio riceve le similitudini, non altrimenti che s'elle fossero naturali, e la poesia le da senza essa similitudine, e non passano all'impressiva per la via della virtù visiva come la pittura". "La pittura rappresenta al senso con più verità e certezza le opere di natura, che non fanno le parole o le lettere, ma le lettere rappresentano con più verità le parole al senso, che non fa la natura. Ma dicemmo essere più mirabile quella scienza che rappresenta le opere di natura, che quella che rappresenta le opere dell' operatore, cioè, le opere degli uomini, che sono le parole, com'è la poesia, e simili, che passano per la umana lingua”. La pittura serve a più degno senso che la poesia, e fa con più verità le figure delle opere di natura che il poeta, e sono molto più degne le opere di natura che le parole, che sono opere dell'uomo; perchè tal proporzione è dalle opere degli uomini a quelle della natura, qual è quella ch' è dall'uomo a Dio. Adunque è più degna cosa l'imitar le cose di natura, che sono le vere similitudini in fatto, che non parole imitare i fatti e le parole degli uomini".

${ }^{8}$ ALBERTI, Leon Battista, op. cit., p. 103 e 105: "Ma piacerammi sia il pictore, per bene potere tenere tutte queste cose, huomo buono et docto in buone lettere [...]"; "Adunque si vede quanta lode porgano simile inventioni al artefice, pertanto consiglio ciascuno pittore molto si faccia familiare ad i poeti, rethorici et ad li altri simili dotti di lettera, sai che costoro doneranno nuove inventione o certo aiuteranno abbello componere sua storia, per quali certo adquisteranno in sua pictura molte lode et nome".

9 DANIELlO, Poetica, p. 26. In BAROCCHI, Paola. Trattati del Cinquecento fra Manierismo e Controriforma. Bari: Gius. Laterza e Figli Editore, 1960, p. 444, nota 4: "Per tanto dico non senza grandissima ragione, essere stata essa poetica [facultà] dagli antichi e sapintissimi uomini alla pittura assomigliata [...]".

${ }^{10}$ PINO, Paolo, op. cit.: p. 15 " [...] ci conviene haver la natura e i fatti propicii, et nascere com tal dispositione com i poeti [...]". Cf. Anexo, p.46. 
um intelecto rude pode fazer-se excelente em sua arte com a acuidade do estudo. ${ }^{11}$ Em idêntica declaração, Dolce pontua que atingir a perfeição pela excelência da pintura é empresa difícil e fatigante, e graça concedida pela liberalidade dos céus somente a poucos homens porque é necessário que o pintor, semelhante ao poeta, nasça enquanto tal e seja filho da natureza. ${ }^{\mathbf{1 2}}$ Com relação a esta argumentação, ambos vão ao encontro ao preceito de Quintiliano, para quem o estudo sem o talento no orador não vale coisa alguma. ${ }^{\mathbf{1 3}}$

Em outra passagem Pino afirma que, pintura é a própria poesia, isto é, invenção, porque traz à luz aquilo que não existe, ou seja, transforma em imagem o que não é perceptível ao olho humano. ${ }^{14}$ Mais à frente, ele declara que a pintura é capaz, de modo semelhante à poesia, de figurar todos os elementos do mundo como o céu, a lua, as estrelas, a chuva, neve, as estações, e também o caráter humano em suas paixões. ${ }^{15}$ Pino reconhece ampla liberdade ao pintor e ao poeta. Ao primeiro, de fingir diversas coisas de diferentes modos, ao segundo, de poder argumentar e escrever sobre todas elas. Afirmação que se remete tanto à Arte Poética, de Horácio, ${ }^{16}$ quanto à Poética, de Bernardino Daniello. ${ }^{17}$

Dolce, por sua vez, transforma a aproximação entre pintura e poesia numa relação mais intrínseca ao instituir uma irmandade entre as duas artes, fazendo uma analogia com o

\footnotetext{
${ }^{11}$ Idem, ibidem, p. 21: “[...] il qual era d'imparar il modo de farmi pittore eccellente. Questo è impossibile. O, nò sapete voi? Che vi bisogna nascer come poeti, mà gli oratori si fanno, perchè, nell'altre arti sì liberale, come mecanice vi sono i gradi, le regole ordinate, per le quali si perviene alla perfettione del suo fine, tal che ciascuno per rozzo intelletto che si sia, egli si può far eccellente. Il che non si può nell'arte nostra". Cf. Anexo, p. 62.

${ }^{12}$ DOLCE, Lodovico, op. cit., p. 186: "E benchè il pervenire alla perfezzione della eccellenza della pittura, alla quale fa mestiero di tante cose, sia impresa malagevole e faticosa, e grazia dalla liberalità de'cieli conceduta a pochi (perchè nel vero bisogna che'l pittore, così bene come il poeta, nasca e sia figliuolo della natura, non è da credere (come toccai da prima) che ci sia una sola forma del perfetto dipingere". Cf. Anexo, p. 132.

${ }^{13}$ QUINTILIANO, M. Fábio, op. cit., p. 63: “Também sei se costuma questionar, qual das duas coisas conduz mais para a Eloqüência, a Natureza, ou o Estudo. [...] Porque se nós considerarmos estas duas coisas separadas uma de outra, e em diferentes indivíduos, o talento natural só per si, ainda sem estudo, valerá muito; o Estudo sem talento, nada. Concorrendo porém unidas estas duas coisas no mesmo orador é necessário fazer distinção: ou elas concorrem em um grau medíocre, e então prepondera ainda o natural sobre o Estudo; ou em um grau perfeito, e neste caso mais deverá o orador ao seu estudo, e diligência que ao seu talento."

${ }^{14}$ PINO, Paolo, op. cit., p. 16: "Et perchè la pittura è propria poesia, cioè, inventione, la qual fà apparere quello, che non è [...]".Cf. Anexo, p. 51.

${ }^{15}$ Idem, ibidem, p. 10: "Questa è quella poesia, che vi fà non solo credere, ma vedere il cielo ornato del Sole, della Luna, e delle stelle, la pioggia, e neve, le nebie causate da venti, l'acqua e la terra". Cf. Anexo, p. 30.

${ }^{16}$ HORÁCIO, op. cit., p. 51-53: "Direis vós que a pintores e a poetas igualmente se concedeu, desde sempre, a faculdade de tudo ousar".

${ }^{17}$ DANIELlO, Bernardino. Della Poética. In WeINBERG, Bernard. Trattati di Poetica e Retorica del Cinquecento. Roma: Laterza Editore. 1970-1974. (texto retirado do site www.bibliotecaitaliana.it), p. 7: “[...] ad esso poeta determinata, anzi essergli conceduto ampia licenza (sì come ancora è al dipintore di finger molte e diverse cose diversamente) di potere di tutte quelle cose che in grado il fiano, ragionare et iscrivere".
} 
proposto por Vasari, que havia afirmado serem irmãs, escultura e pintura, porque geradas de um mesmo pai, o desenho, e nascidas a um único tempo. ${ }^{18}$ Giovanni Paolo Lomazzo, no final do século XVI, na idêntica linha de pensamento de Vasari, acabaria por dizer que pintura e poesia vieram à luz num único nascimento. ${ }^{19} \mathrm{Na}$ Antiguidade grega era já reconhecido que as duas artes diferiam quanto aos meios e modo de expressão, sendo, no entanto, consideradas quase idênticas quanto à sua natureza fundamental, conteúdo e propósito. O dito atribuído por Plutarco a Simônides de Cós (c. 556 a c. 467 a.C.) de que "a pintura é uma poesia muda, e a poesia, uma pintura falante", foi citado com freqüência por vários tratadistas, ${ }^{20}$ inclusive Daniello. ${ }^{21}$

A peculiaridade do diálogo de Lodovico Dolce no tocante a esta discussão e em comparação a outros autores que trataram do mesmo assunto, encontra-se no fato de que ele foi o primeiro letrado, entre os séculos XV e XVI, a escrever um tratado sobre pintura (no geral cabia aos artífices a discussão sobre as artes figurativas), extraindo seus argumentos a partir de antigas autoridades ligadas com maior ênfase ao âmbito das letras. Seu texto está repleto de menções e citações de poetas e escritores antigos como Homero, Virgílio, Horácio, ou modernos, como Dante, Petrarca, Ariosto, além de que em vários trechos do texto ele faz cotejos entre poesia e pintura, poeta e pintor. ${ }^{22}$ Estabelece a máxima de que

\footnotetext{
${ }^{18}$ VASARI, Giorgio, op. cit., p. 37: "Dico adunque, che la scultura e la pittura per il vero sono sorelle, nate di un padre che è il disegno, in un sol parto e ad un tempo".

${ }^{19}$ LOMAZZO, Giovanni Paolo, Trattato dell arte della pittura, scoltura et archittetura, Milan, 1585, VI, 65, p. 486. In LEE, R. W, op. cit., p. 197, nota 2: "Considerando la cagione onde sia nato quel detto antico tanta esser la conformità della poesia con la pittura, che quasi nate ad un parto l'una pittura loquace e l'altra poesia mutola s'appellarono."

${ }^{20}$ LEONARDO, op. cit., p. 16: "La pittura è una poesia muta, e la poesia è una pittura cieca [...]". Paolo Pino (de modo implícito), Varchi e Lomazzo. VARCHI, Benedetto, citado por BAROCCHI, Paola. Trattati del Cinquecento fra Manierismo e Controriforma. Bari. Gius. Laterza e Figli Editore, 1960, p. 444, nota 4: "Benché il Cielo desse forma alla pittura nelle linee et la facesse conoscere per poesia muta, non restó egli però per tempo alcuno di congiugnere insieme la pittura e la poesia, a ciò che, se l'uma stesse muta, l'altra ragionasse et il pennello con l'artifizio et co' gesti maravigliosi mostrasse quello che gli dettasse la penna e formasse nella pittura le invenzioni che se le convengono". DOLCE, Lodovico, op. cit.: p. 152: "[...] e similmente è propria la similitudine tra il poeta e il pittore, avendo alcuni valenti uomini chiamato il pittore poeta mutolo, e il poeta, pittore che parla". Cf. Anexo, p. 102.

${ }^{21}$ DANIELLO, Bernardino, op. cit. p. 7: "[...] e detto essa pittura altro non esser che um tacito e muto poema et allo incontro pittura parlante la poesia".

${ }_{22}$ Clama a autoridade de Petrarca ao denominar Homero, o primeiro pintor das memórias antigas. DOLCE, Lodovico, op. cit.: p. 155: "Di qui il nostro Petrarca chiamò Omero, "Primo pittor de le memorie antiche". Menção feita no Trionfo della Fama, III, v. 15. Cf.: PETRARCA. Triunfos. São Paulo: Editora Hedra, 2006, Tradução de Camões, Introdução e Notas de Pedro Heise, p. 212-214: “[...] Socrate e Senofonte, e quell'ardente/vecchio a cui fur le Muse tanto amiche/ch 'Argo e Micena e Troia se ne sente:/questo cantò gli errori e le fatiche/del figliuoli di Laerte e d'uma diva,/primo pintor delle memorie antiche [...]". "Sócrates e Xenofontes, e aquele ardente/velho de que as Musas foram amigas,/e Argos e Micena e Tróia o sente:/este
} 
não só poetas, mas todos os escritores são igualmente pintores e não só poesia, como também história ou toda composição de homens doutos é pintura. ${ }^{23}$

$\mathrm{O}$ argumento serve no diálogo de Dolce a dois propósitos. Em primeiro lugar, defender a premissa condicional de que, se homens doutos são aptos a criar pinturas que decorram de suas composições, do mesmo modo eles estarão habilitados a tecer juízo sobre a arte do pintor. ${ }^{24}$ Seu raciocínio é singular para o período, porque pintores não tomavam com seriedade o julgamento de uma pintura pelas palavras de um letrado. ${ }^{25}$ A influência de tal premissa deveu-se certamente a Baldassare Castiglione que, no Cortesão, aconselha ao homem de corte ter conhecimento de pintura, por ser algo útil e pelo fato de ter sido apreciada numa época remota em que os homens eram mais valorosos. Ele sugere também ao cortesão que entenda de escultura, a fim de poder estabelecer juízo de valor sobre a excelência das estátuas antigas e modernas, vasos, edifícios, medalhas, camafeus, entalhes e coisas similares; e apreenda por meio dela a discernir a beleza dos corpos vivos, a delicadeza dos semblantes, a proporção dos homens e de outros animais. ${ }^{26}$ Tomando como exemplo este preceito de Castiglione, Dolce fez apenas uma adaptação para seu diálogo, afirmando que qualquer homem tem a capacidade de avaliar a pintura.

cantou os trabalhos e as fadigas do filho de Laerte, navegando, grão pintor das memórias antigas [...]".Cf. Anexo, p. 104.

${ }^{23}$ DOLCE, Lodovico, op. cit., p. 155: “[...]ché pittura è la poesia, pittura la istoria e pittura qualunque componimento de'dotti'. Este argumento de Dolce é encontrado na Antiguidade. Plutarco menciona esta qualidade (de relatar imagens com distinção) em Tucídides ao mencionar a descrição vívida que o historiador faz de uma batalha. E Luciano, antecipando Petrarca, já havia denominado Homero "o melhor dos pintores" ao fazer uma descrição do físico de Menelau. Cf. LEE, R.W. op. cit., p. 197, nota 6. Cf. Anexo, p. 104.

${ }^{24}$ Idem, ibidem, p. 154: "E prima anco vorrei che me dichiariste, se uno, che non sia pittore, è atto a far giudicio di pittura. È vero che io trovo l'esempio in voi, che, senza mai aver tocco pennello, sete, come ho detto, giudiciosissimo in quest'arte: ma non ci è più che un Aretino". Cf. Anexo, p. 104.

${ }^{25}$ Idem, ibidem: "E disidero d'intender ciò per questa cagione: che sono alcuni pittori, i quali si sogliono ridere, quando odono alcun letterato ragionar della pittura". Cf. Anexo, p. 104.

${ }^{26}$ CASTIGLIONE, Baldassare. O Cortesão. Tradução Carlos Nilson Moulin Louzada. São Paulo, Editora Martins Fontes, 1997, p. 78-79: "Basta dizer que o nosso cortesão precisa ter conhecimentos sobre a pintura, sendo ela honesta, útil e apreciada naqueles tempos em que os homens eram muito mais valorosos que hoje; e, mesmo que outra utilidade ou prazer nela não encontrassem, além de aprenderem a julgar a qualidade das estátuas antigas e modernas, dos vasos, dos edifícios, das medalhas, dos camafeus, dos entalhes e coisas similares, ela também faz conhecer a beleza dos corpos vivos, não somente na delicadeza dos rostos, mas na proporção de todo o resto, tanto dos homens como de qualquer outro animal. Assim, verificais como conhecer a pintura é causa de imenso prazer. E pensem nisso aqueles que tanto deleite têm ao contemplar as belezas de uma mulher, que lhes parece estarem no paraíso, mas não sabem pintar: se o soubessem, ficariam muito mais contentes, pois conheceriam mais perfeitamente aquela beleza, que no coração lhes provoca tamanha satisfação". É preciso apenas lembrar que Dolce foi o responsável pela correção e revisão do texto da obra de Castiglione, publicada pela Editora Gioliti, em 1552 e 1556, com várias reedições. Idem, ibidem, p. XLIII. 
O segundo propósito está ligado ao anseio de Dolce pelo reconhecimento e nobilitação de seu ofício. Papel ilustre que desfruta o poeta e anseia o pintor. Contudo, Dolce não é poeta, pintor, ou historiador, mas homem douto, que, por suas composições em prosa, deseja alcançar o caráter universal, como atinge a poesia e não o particular como as narrativas históricas. Esta defesa de seu ofício contrapõe-se à observação de Aristóteles, que via a poesia como arte mais filosófica e séria do que a história (a despeito de não diferir as duas no tocante à sua composição, se em versos ou prosa). ${ }^{27}$ Aristóteles aponta a divergência entre ambas pelo fato da poesia referir-se ao universal, ou seja, representar o que é possível segundo a verossimilhança e a necessidade, e a história referir-se ao particular, por narrar fatos que já aconteceram. ${ }^{28}$ Tanto quanto a poesia que transforma palavras em pintura, as narrativas de um historiador como Plínio obtêm o mesmo efeito, pelo detalhamento com que descrevem os feitos de pintores antigos. Dolce intenta resultado similar por meio de seu diálogo, que ele desperte imagens e crie pinturas na mente de seu leitor. Para tanto, vale-se em muitas passagens da construção de ecfrases, ao descrever com pormenorização a composição de algumas pinturas. Nesse sentido, ao nivelar-se ao poeta e ao historiador, Dolce requer o reconhecimento de sua obra.

Vimos que a base de todo o parentesco que Pino e Dolce estabelecem entre pintura e poesia encontra-se numa primeira instância, na imitação. Outros teóricos tomaram semelhante posição, colocando, porém, algumas objeções. Leonardo, já no século anterior, havia afirmado que ambas as artes tinham este idêntico fim, ${ }^{29}$ o imitar a natureza, apesar de serem completamente diferentes. Varchi em 1549 ratificará o mesmo argumento. ${ }^{30}$ Mas, a

\footnotetext{
${ }^{27}$ ARISTÓTELES, op. cit. p. 78: "Pelas precedentes considerações se manifesta que não é ofício de poeta narrar o que aconteceu; é, sim, o de representar o que poderia acontecer, quer dizer: o que é possível segundo a verossimilhança e a necessidade. Com efeito, não diferem o historiador e o poeta, por escreverem verso ou prosa (pois que bem poderiam ser postas em verso as obras de Heródoto, e nem por isso deixariam de ser história, se fossem em verso o que eram em prosa), diferem, sim, em que diz um as coisas que sucederam, e outro as que poderiam suceder".

${ }^{28}$ Idem, ibidem: "Por isso a poesia é algo de mais filosófico e mais sério do que a história, pois refere aquela principalmente o universal, e esta o particular. Por "referir-se ao universal" entendo eu atribuir a um indivíduo de determinada natureza pensamentos e ações que, por liame de necessidade e verossimilhança, convêm a tal natureza; e ao universal, assim entendido, visa a poesia, ainda que dê nomes aos seus personagens; particular, pelo contrário, é o que fez Alcibíades ou o que lhe aconteceu".

${ }^{29}$ LEONARDO, op. cit., p. 16: "La pittura è una poesia muta, e la poesia è una pittura cieca, e l'una e l'altra vanno imitando la natura quanto è possibile alle loro potenze [...]".

${ }^{30}$ Segundo VARCHI, Benedetto. Due Lezioni, Florence, 1549, p. 111. In LEE R. W., op. cit., p. 204: "Essendo il fine della Poesia e della Pittura il medesimo, secondo alcuni, cioè, imitare la natura, quanto possono il più, vengono ad essere uma medesima, e nobili ad um modo, e però volte gli scrittori danno a'
} 
despeito da distância entre séculos, ambos se aproximam ao expor divergências profundas entre pintura e poesia, no que concerne aos meios, vias de expressão e resultado final da obra. Em contrapartida, teóricos como Dolce e Pino, na ânsia de defender sua tese, enfatizam o estreito vínculo entre as duas artes, tentando minimizar seus contrastes. Mesmo assim, o próprio Dolce não pode se furtar de apontar discordâncias marcantes ao declarar que, "o pintor tende a imitar por meio de linhas e cores, no plano de uma tábua, tela ou muro, tudo o que se lhe manifesta ao olhar (o que inclui a representação da vida mental e psíquica do homem - ou paixões da alma - que se expressam pelo movimento do corpo), enquanto o poeta por meio de palavras imita não só o que se lhe demonstra ao olho, mas também tudo aquilo que se lhe apresenta ao intelecto"31 (o que implica dizer, tudo aquilo que ele apreende e se transforma em conceitos ou processos de pensamento). Nesse sentido, pelas palavras de Dolce vemos que uma oposição relevante entre pintura e poesia estaria na atividade mental através da qual poeta e pintor apreendem as formas da natureza e as expressam em suas obras, sendo que a proporção desta diferença encontra-se nos processos que vão da imaginação ao efeito. Poderíamos dizer que tanto pintor quanto poeta ao produzirem sua obra captam a similitude das formas naturais através do olho. Tais formas encaminham-se ao compartimento cerebral que as transforma em impressões, as quais alimentarão a imaginação de ambos os artífices. O poeta, no entanto, transmuta o conteúdo da imaginação fomentada pelas impressões, e os expressa através de palavras. O pintor, por sua vez, transfigura esse mesmo conteúdo e o exprime em imagem na pintura. A poesia transforma as formas naturais em palavras. A pintura as recria em imagens. E em todo este processo está a diferença maior entre as duas artes.

Essa característica peculiar a cada uma das artes tornou-se forte argumento para que no século XVI, concomitante aos defensores da doutrina do ut pictura poesis, fossem arroladas por alguns humanistas diferenças quase instransponíveis entre ambas. Como mencionado anteriormente, Benedetto Varchi foi um deles. Uma das distinções prescritas por ele, refere-se ao fato de que somente o poeta possui a habilidade de imitar o lado interior do homem, ou seja, de expressar os conceitos de sua mente e as paixões de sua alma. Já o pintor, em sua opinião, não tem essa capacidade, porque é possível a ele imitar

Pittori quello, che è de' Poeti, e così per lo contrario, onde Dante, che ... seppe tutto, e tutto scrisse, pose nel Ventinovesimo canto del Purgatorio: 'Ma legge Ezechiel, che gli dipinse".

${ }^{31}$ DOLCE, Lodovico, op. cit., p. 152. Cf. Anexo, p. 102. 
somente as formas externas, ou então, os corpos e as feituras de todas as coisas naturais. No entanto, Varchi declara ser eventualmente possível ocorrer confluências entre ambos, quando ocorrer de o poeta quase pintar o mundo externo e o pintor retratar o interior da alma humana expressando-os pelos afetos. ${ }^{32}$ Dolce defenderá de modo veemente o fato do pintor ser dotado de uma habilidade tal como o poeta, de expressar os afetos da alma ${ }^{33}$ (tanto quanto o haviam feito Leonardo e Alberti). ${ }^{\mathbf{3 4}}$

Porém, as divergências entre as artes suscitadas por alguns humanistas eram parte de uma discussão que não interessava aos teóricos do ut pictura poesis, preocupados em estabelecer uma legítima interligação entre elas. Pino e Dolce fazem parte desse grupo de teóricos que a partir da segunda metade do século XVI, adotaram e empregaram esta doutrina às artes figurativas, instituindo uma correlação entre pintura e poesia, aplicando à primeira a gama de conhecimentos que os antigos tinham desenvolvido para a arte da literatura, apropriando-se de argumentos dos dois principais tratados sobre poesia, da Antiguidade grega, a Poética, de Aristóteles e da Antiguidade Latina, a Arte Poética, de Horácio.

Como mencionado anteriormente, muitas são as razões que os levaram a arquitetar este projeto, entre as principais, defender a pintura do papel de simulacro creditada por Platão, conceder-lhe uma importância de arte liberal e de modo concomitante nobilitar o ofício do pintor. $\mathrm{O}$ intercâmbio de conhecimentos entre pintor e poeta na convivência da corte alavancou este processo. Outro fator importante foi o avanço nos estudos de textos antigos, uma vez que o século XVI assistiu ao surgimento de vários tratados sobre preceitos

\footnotetext{
${ }^{32}$ VARCHI, Benedetto. Due Lezioni, 1549, pp.113-114. In LEE, R. W. op. cit. p. 254, nota 283: "I Poeti imitano il di dentro principalmente, cioè i concetti, e le passioni dell’animo, se bene molte volte discrivono ancora, e quasi dipingono colle parole $\mathrm{i}$ corpi, e tutte le fatezze di tutte le cose così animate, come inanimate, et i Pittori imitano principalmente il di fuori, cioè i corpi, e le fatezze di tutte le cose ... pare che sia tanta differenza fra la Poesia, e la pittura quanta è fra l’anima, e il corpo, bene è vero, che come i Poeti discrivono anchora il di fuori, così il Pittori mostrano quanto più possono il di dentro, cioè gl affetti, et il primo, che ciò anticamente facesse questo, secondo che racconta Plinio, fu Aristide Thebano, e modernamente Giotto. Bene è vero, che i Pittori non possono sprimere così felicemente il di dentro, come il di fuori".

${ }^{33}$ DOLCE, Lodovico, op. cit., p. 186: "Né può movere il pittore, se prima nel far delle figure non sente nel suo animo quelle passioni, o diciamo affetti, che vuole imprimere in quello d'altrui. Onde dice il tante volte allegato Orazio: "Se vuoi ch'io pianga, è mestiero che tu avanti ti dolga teco". Né è possibile che alcuno con la mano fredda riscaldi colui ch'egli tocca". Cf. Anexo, p. 131-132.

${ }^{34}$ ALBERTI, op. cit., p. 95: "Sono alcuni movimenti d'animo detti affezione: come era dolore, gáudio et timore, desiderio et simili altri; sono movimenti de'corpi: muovonsi i corpi in più modi, cresciendo, dicrescendo, infermandosi, guarendo et mutandosi da luogo a luogo. Ma noi dipintori i qualli volliamo coi movimenti delle membra mostrare i movimenti dell'animo, solo riferiamo di quel movimento si fa mutando el luogo. [...]".
} 
poéticos, conforme já exposto antes, ou comentários e traduções às obras de Aristóteles e de Horácio.

Somam-se a esses aspectos o fato da edificação de uma teoria artística encontrar-se em outro patamar. Alberti e Leonardo haviam, no século anterior, investigado, argumentado e normatizado as artes figurativas sob o ponto de vista de uma práxis científica, associada a preceitos matemáticos. Assentadas as bases teóricas sob este aspecto, restava aos teóricos pósteros argumentar as artes figurativas, em especial a pintura, no sentido de delimitá-la nos termos de seus fundamentos estéticos, ou seja, sua natureza essencial, seu conteúdo e seu fim. Contudo, não havendo sobrevivido nenhum tratado da Antiguidade que discorresse de modo peculiar sobre a pintura, exceto as obras de Aristóteles, e posteriormente Horácio, que cumpriam este fim no tocante à poesia, os teóricos da segunda metade do século XVI evocaram a autoridade destes dois tratados, apropriando-se de algumas proposições neles contidas, a fim de moldá-los aos argumentos dos quais eles se utilizaram para instituir uma teoria da pintura, determinando para ela uma relação intrínseca com a poesia e estruturando-a sob bases retóricas. Se a poesia havia usufruído o papel de arte liberal na Antiguidade por estar vinculada a preceitos de ordem retórica, a pintura poderia também vir a sê-lo, se se determinasse para sua concepção os mesmos procedimentos que cabiam à poesia.

O hábito de associar escritores com o imaginário vívido ou pleno de cor com pintores era conhecido desde os antigos. O século XVI, enquanto êmulo da Antiguidade grego-latina, tomou emprestado do período clássico a idéia para estabelecer seus próprios paralelos, no caso, entre pintura e poesia, evocando aqueles dois tratados para justificar seus argumentos. ${ }^{35}$

Aristóteles e Horácio, cada um em sua devida época histórica, haviam proposto pequenas analogias entre as duas artes que servissem a ratificar os argumentos dos quais necessitavam desenvolver em suas obras. Contudo, não chegaram a prescrever uma identificação tão próxima entre elas, como realizaram os teóricos do século XVI, Pino e Dolce inclusive.

Como visto acima, Aristóteles havia dito por exemplo que o homem em ação é o objeto de imitação entre os pintores, assim como entre os poetas. E ao argumentar que a

\footnotetext{
${ }^{35}$ LEE, R. W. op. cit., pp. 197-202.
} 
trama dos fatos é a essência da tragédia, ele havia feito uma comparação com os pintores, observando que uma tela manchada aleatoriamente com as mais belas cores não nos causaria tanta satisfação quanto um retrato feito em linhas gerais. ${ }^{\mathbf{3 6}}$ Aristóteles propõe com este argumento que a trama na tragédia de um modo geral assemelha-se ao esboço do desenho na pintura. Todavia, este cotejo não abarcou em seu raciocínio maiores implicações, de modo que tais paralelos realizados por ele não significavam nada além do que um meio de esclarecer e ilustrar seu discurso sobre a tragédia. Por outro lado, resultou num importante argumento para os teóricos do XVI, que o utilizaram a fim de desenvolver sua doutrina das artes irmãs.

O segundo tratado tomado como autoridade para este escopo foi a Ars Poética, de Horácio, que lhes proporcionou argumentos a partir de dois trechos. O primeiro, a passagem na qual Horácio descreve uma pintura de híbridos grotescos cuja inverossimilhança desperta o riso em seus observadores. Ele a compara com um livro de quem imagens vãs são amoldadas como sonhos de um homem doente. Assim, a despeito de admitir igual direito de pintores e poetas a terem liberdade de imaginação, preceitua, no entanto, que ela não perca as linhas da coerência e do verossímil. ${ }^{37}$

O outro trecho foi o famoso dito ut pictura poesis no qual Horácio, após solicitar indulgência aos leitores por falhas que poderiam vir a ocorrer mesmo na grande literatura, reivindicando ao mesmo tempo uma maior flexibilidade de julgamento crítico por parte deles, declara com efeito que a poesia deveria ser equiparada à pintura. A primeira, por despertar o deleite quando próxima ao leitor, permitindo-lhe frui-la de modo recôndito. A pintura despertando idêntico prazer, quando observada à distância, possibilitando que pequenas impressões vistas de perto tornem-se um todo coeso contempladas de longe. Se a

\footnotetext{
${ }^{36}$ ARISTÓTELES, op. cit., p. 75: “[...] muito melhor conseguirá (lograr o efeito trágico) a tragédia que mais parcimoniosamente usar desses meios, tendo, no entanto, o mito ou a trama dos fatos [...]. Portanto, o mito é o princípio e como que a alma da tragédia; só depois vêm os caracteres. Algo semelhante se verifica na pintura: se alguém aplicasse confusamente as mais belas cores, a sua obra não nos comprazeria tanto, como se apenas houvesse esboçado uma figura em branco. A tragédia é, por conseguinte, imitação de uma ação e, através dela, principalmente, [imitação] de agentes".

${ }^{37}$ HORÁCIO, op. cit., p. 51: "Se um pintor quisesse juntar a uma cabeça humana um pescoço de cavalo e a membros de animais de toda a ordem aplicar plumas variegadas, de forma a que terminasse em torpe e negro peixe a mulher de bela face, conteríeis vós o riso, ó meus amigos, se a ver tal espetáculo vos levassem? Pois crede-me, Pisões, em tudo a este quadro se assemelharia o livro, cujas idéias vãs se concebessem quais sonhos de doente, de tal modo que nem pés nem cabeça pudessem constituir uma só forma. Direis vós que 'a pintores e a poetas igualmente se concedeu, desde sempre, a faculdade de tudo ousar'. Bem o sabemos e, por isso, tal liberdade procuramos e reciprocamente e concedemos, sem permitir, contudo, que à mansidão se junte a ferocidade e que se associem serpentes a aves e cordeiros a tigres".
} 
poesia permite o prazer em uma única vez, a pintura, por seu turno, permite diversos momentos de fruição, por poder ser observada sob vários ângulos diferentes. ${ }^{\mathbf{3 8}}$

Assim, estas passagens contidas nos dois tratados antigos foram retiradas de seu contexto inicial, apropriadas pelos teóricos do XVI, e utilizadas por eles enquanto argumentos de legitimação do vínculo que queriam prescrever entre poesia e pintura.

Uma outra questão vinculada à relação pintura-poesia, levemente abordada no capítulo primeiro, diz respeito a algumas problemáticas que se configuravam naquele período no âmbito da língua italiana, as quais Dolce fez uso argumentativo em seu tratado. Retornando à temática, poderíamos observar que no período do Renascimento, apesar da Itália dividida em cidades autônomas, havia já esboçada uma preocupação para se instituir um estado unificado e, concomitante a este fato, surgiam contendas entre os letrados visando a definição de um estilo lingüístico do vernáculo. Como já mencionado anteriormente, Pietro Bembo foi figura eminente e central na contenda sobre a definição de um paradigma da língua italiana. No início do século XVI havia dois movimentos literários paralelos. O primeiro deles que era dominante em Roma, ligava-se à influência de Cícero e tinha como mote il bello scrivere latino. Seus expoentes mais importantes foram Sadoleto, Bembo e Ighirami, que enfatizavam a preocupação com o "estilo", o que direcionava os escritos literários a dois caminhos, um deles caracterizado por um artificialismo culto e elegante, o outro, ligado a noções de bom estilo contidas na literatura retórica da Antiguidade. O segundo movimento ligava-se à língua vernácula que, a despeito de apresentar o mesmo questionamento no tocante ao estilo, estimulava o culto a um estilo passado tendo por influência Petrarca, em lugar de Cícero. Ao que parece, Bembo, apesar de uma posição ambígua, era o líder desse segundo movimento. Trava-se então uma batalha entre o latim e o vernáculo, de um lado, Cícero, de outro Bembo. O estilo vernáculo perfeito teria duas fontes. Primeiro, como Bembo desdenhava a língua falada por considerála corrupta, ele achava que os homens deveriam se expressar por meio da língua dos clássicos, os quais por definição não podiam ser latinos nem gregos, de modo que para ele, o ideal de eloqüência encontrava-se primeiro em Petrarca, depois em Boccaccio, mas nunca em Dante. Segundo, “o objetivo era elevar o vernáculo ao nível mais alto da latinidade em

\footnotetext{
${ }^{38}$ Idem, ibidem, pp. 109-111: “Como a pintura é a poesia: coisas há que de perto mais te agradam e outras, se a distância estiveres. Esta quer ser vista na obscuridade e aquela à viva luz, por não recear o olhar penetrante dos seus críticos; esta, só uma vez agradou, aquela, dez vezes vista, sempre agradará".
} 
matéria de elegância, riqueza de ornamentos, figuras de estilo e abundância de vocabulário, principalmente transferindo formas de uma língua para a outra. O processo, na realidade, principiara espontaneamente muito antes de Bembo, mas era agora formalizado e, poder-seia dizer, quase institucionalizado". 39 Em 1525 ele escreveu a Prose della Vulga Língua, discorrendo sobre esta contenda, onde de acordo com "as variações idiomáticas na Península Itálica, propunha a língua mais usada entre os grandes escritores, como padrão de uso literário". 40 No tocante à prosa, Giovanni Boccaccio, com o Decameron, foi tomado como modelo. A querela mais acirrada se fez com respeito à poesia: Dante ou Petrarca? "Segundo Bembo, o paradigma não poderia ter uma enorme variação lingüística, como no caso de Dante em sua Commedia, por isso Petrarca, com seu Cancioneiro, entrou para o cânone da lírica em língua vulgar". 41

Sendo Dolce um letrado às voltas com questões lingüísticas, uma vez que efetuava todo tipo de atribuições junto a uma Editora, fossem prefácios, revisões ou traduções, as discussões sobre o idioma italiano eram-lhe preocupação freqüente, publicando inclusive em 1550, as Osservazioni nella Volgar Língua. Pietro Bembo certamente fora uma de suas influências, porque Dolce havia sido curador de suas obras. A polêmica sobre o paradigma da língua italiana não lhe passou despercebido e ele a introduziu em seu diálogo, aproveitando o momento para estabelecer idêntica linha de pensamento com o intuito de fazer um cotejo com a pintura, traçando ao mesmo tempo uma divergência literária entre toscanos e venezianos.

Em certa passagem, um dos interlocutores de seu diálogo, o gramático Fabrini assevera que Homero obteve a primazia entre os poetas gregos, Virgílio, entre os latinos e Dante, o primeiro entre os toscanos, cabendo assim a Michelangelo a preeminência entre os pintores e escultores de sua época. Aretino, o segundo interlocutor, admite a maestria de Michelangelo, mas afirma que o gramático traz à luz argumentos pré-estabelecidos por amor à sua pátria, Florença e aos seus conterrâneos. Adverte que no tempo de Alexandre Magno louvava-se deveras Apeles, mas não se deixava de apreciar Zêuxis, Protógenes, Timantes, Polignoto e outros excelentes artistas. Igualmente no tocante à literatura, Virgílio

39 SHEARMAN, John. O Maneirismo. São Paulo: Editora Cultrix e Editora da Universidade de São Paulo, 1978, p. 35-38.

${ }^{40}$ PETRARCA, Triunfos. Tradução de Camões. Introdução e notas de Pedro Heise. São Paulo: Editora Hedra Ltda., 2006, p. 15.

${ }^{41}$ Idem, ibidem. 
foi sempre tomado por divino entre os poetas latinos, mas em nenhum momento deixou-se de ler Ovídio, Horácio, Lucano, Estácio e outros poetas, que a despeito de suas diferenças, todos em seus gêneros foram perfeitos. E não obstante a plena doutrina de Dante, não poder-se-ia deixar de louvar a elegância estilística de Petrarca, equiparando-o ou colocando-o até mesmo em primeiro plano ao florentino.

Essa discussão lingüística no texto traz à luz as diferenças de estilo entre poetas clássicos e modernos, confluindo para o surgimento de duas controvérsias. A primeira querela opõe Ovídio e Horácio a Vírgilio, quanto aos autores clássicos. E Petrarca contra Dante entre os modernos. Petrarca é aclamado por seu vigor agradável, e portanto elevado a um patamar mais alto do que Dante e sua doutrina moralizante. O primeiro alcançaria (segundo os venezianos) maior perfeição em seu estilo leve do que o segundo, por sua maneira séria. Petrarca representaria a elegância de estilo, enquanto Dante, o sumo e a doutrina. As duas controvérsias que daí decorrem são: a primeira, definir o propósito da literatura. A segunda, em qual língua um escritor contemporâneo deveria compor suas obras: em língua latina ou vulgar. E dentre elas, qual teria maior mérito?

O caminho da primeira polêmica já havia sido traçado por Cícero em suas argumentações sobre a Arte Retórica, ${ }^{42}$ onde ele havia sugerido que os discursos deveriam obedecer a três objetivos: o doutrinar, deleitar e o comover (docere, delectare, movere) em seu De Optimo Genere Oratorum, restando a questão de qual dos três deveria caber a supremacia. Horácio, cuja "Arte Poética” no século XVI havia despertado grande atenção dos letrados e poetas tornando-se-lhes uma autoridade, inclusive para Dolce (face às várias menções no diálogo), afirma aqui e acolá em seu tratado sua preferência por obras que despertem o prazer, em detrimento da doutrina e da comoção, o que ele comprovou através do caráter de seus escritos posteriores. Em Veneza especialmente, os teóricos o tomaram como paradigma, reafirmando que o objetivo principal da literatura deveria ser o deleite. A Poética, traduzida por Daniello em 1536, e o "Naugerius", de Girolamo Fracastoro, publicado em 1555, são exemplos desses teóricos, em cujas obras enfatizavam fortemente este princípio.

\footnotetext{
${ }^{42}$ É preciso salientar a grande influência de Cícero sobre Dolce, uma vez que, ele também havia feito uma tradução do De Oratore, para a língua italiana.
} 
Quanto à segunda polêmica, as obras de Virgílio, Cícero e Dante são alinhadas a uma corrente que as define enquanto "discursos formais". As obras de Horácio, Petrarca e Boccaccio, em contrapartida, são rotuladas como "discursos informais". Tanto Baldassare Castiglione como Pietro Bembo tomaram partida neste debate, que tomou forma na década em que Dolce compunha seu diálogo.

Em Veneza, o percurso dessas controvérsias leva a duas vias simultâneas. Uma delas tende a promover as obras de Petrarca (muitas edições foram publicadas nas primeiras décadas do século XVI), a outra inclina-se a hostilizar Dante, o "florentino", por seu "estilo grave sem agradabilidade". O círculo humanístico liderado por Aretino, ao qual pertenciam igualmente Daniello e Fracastoro, investiu todo o peso de sua erudição e prestígio na defesa da causa da literatura enquanto deleite, e na escolha de Petrarca. Estas questões são um dos pontos divergentes entre o ambiente humanista veneziano e o florentino, delineados no tratado de Dolce.

Ele não somente discorre sobre esta polêmica linguística, como também transfere as mesmas discussões e questionamentos para a criação da pintura, semelhante ao que Cícero fizera, colocando em debate a função do discurso. Dolce pergunta-se, em seu texto, se a pintura tem como fim principal o doutrinar, o deleitar ou o comover. Segundo ele, doutrina e comoção têm papel importante, mas o deleite deve ser o maior mérito da pintura.

Outros elementos retóricos tornaram-se igualmente vínculos relevantes para o critério de legitimação da intrínseca relação entre pintura e poesia, como invenção, doutrina, deleite, referidos acima, tanto quanto o decoro. Fatores como o do pintor letrado e a importância da expressão fisionômica e corporal também poderiam ser acrescidos.

$\mathrm{Na}$ oratória, o primeiro desses elementos utilizado nos procedimentos argumentativos forenses, a inventio, representa o ato de encontrar pensamentos adequados à matéria que se pretende argüir, que sirvam como instrumentos intelectuais e afetivos para obter a persuasão do juiz. ${ }^{43} \mathrm{E}$, como já dito em parágrafos anteriores, é norma que tais pensamentos sejam procurados em autores de reconhecido valor, as auctoritas. ${ }^{\mathbf{4 4}}$

Como referido anteriormente, no tocante à pintura, a inventio implica também no buscar a matéria ou temática a ser representada, em autores clássicos do passado, seja uma

\footnotetext{
${ }^{43}$ LAUSBERG, Heinrich, op. cit., p. 91.

${ }^{44}$ Idem. ibidem, p. 120.
} 
história sacra ou profana, a ser narrada por meio de imagens. Sacra, quando extraída de escritos religiosos como o Velho Testamento. Profana, quando derivada de mitos gregos.

De acordo com Pino, a invenção estende-se no encontrar poesia e história pelo próprio pintor, virtude usada por poucos dos modernos, e algo que considera engenhoso e muito louvável. ${ }^{45}$ Em outra passagem ele define invenção como o bem distinguir, ordenar e compartir as coisas ditas pelos outros, ${ }^{\mathbf{4 6}}$ quer sejam as autoridades antigas, cujas histórias o pintor toma por modelo. A invenção em sua opinião implica igualmente no harmonizar o tema a ser desenvolvido com ações e expressões das figuras, de modo que todas estejam em conformidade, ou sirvam a uma conveniencia ou decoro, para atingir o mesmo objetivo, que é o de representar de modo eficiente a narrativa a qual o pintor se propôs. ${ }^{47}$ Pino prescreve também que as atitudes das figuras devam ser variadas e graciosas, que elas sejam delineadas de corpo inteiro e bastante destacadas, e que no mesmo espaço sejam representados também animais, paisagens e perspectivas. ${ }^{48}$ Em seu preceito de variedade e copiosidade, Pino, em plena harmonia com os preceitos de Alberti, ${ }^{49}$ aconselha que o pintor deva compor suas obras com abundância de figuras de todos os tipos: velhos, jovens, meninos, mulheres, nus vestidos; em diversas posições: distendidas, sentadas, que demonstrem algum esforço; e que apresentem diferentes expressões fisionômicas, de modo que algumas devam ser representadas se afligindo, outras se alegrando, outras ainda cansadas, ou então em repouso ${ }^{\mathbf{5 0}}$, afirmando que é censurável expor numa mesma história figuras com posturas e expressões semelhantes. ${ }^{\mathbf{5 1}}$ Apesar de vinculado a uma tradição

\footnotetext{
${ }^{45}$ PINO, Paolo, op. cit. p. 15-16: "Hor alla seconda parte già detta inventione, questa s'istende nel trovar poesie e historie da se, virtù usata da pochi delli moderni e cosa appresso di me molto ingeniosa e lodabile". Cf. Anexo, p. 49.

${ }^{46}$ Idem, ibidem, p.16: "È ancho inventione il bem distinguere, ordinare e compartire le cose dette dagli altri [...]".Cf. Anexo, p. 49.

${ }^{47}$ Idem, ibidem: "[...] accomodando bene li soggetti agli atti delle figure, et che tutte attendano alla dechiaratione del fine, che l'abitudini delle figure siano varie e gratiose, ch'il maggior numero di esse si vedano integre et spiccate [...]".Cf. Anexo, p. 49.

${ }^{48}$ Idem, ibidem: “[...] ornar l'opere con figure, animali, paesi, prospettive". Cf. Anexo, p. 49.

49 ALBERTI, op. cit., p. 91-92: "Dirò io quella istoria essere copiosissima in quale, a suo luoghi, sieno permisti vecchi, giovani, fanciulli, donne, fanciulle, fanciullini, polli, catellini, ucciellini, cavalli, pechore, hedifici, province et tutte simile cose. Et loderò io qualunque copia quale s'apartenga a quella istoria et interviene, dove chi guarda sopra sta rimirando tutte le cose, ivi la copia del pittore acquisti molta gratia".

${ }^{50}$ PINO, Paolo, op. cit., p. 16: "far nelle tavole intervenire vecchi, giovani, fanciulli, donne, nudi, vestiti, in piedi, distesi, sedenti, che si sforci, altri si dolga, alcuni s'allegri, di quelli che s'affatichi, altri riposi, vivi e morti, sempre variando inventioni, come si convien alla dechiaration dell'atto dell'historia, che si vol dipignere [...]".Cf. Anexo, p. 50.

${ }^{51}$ Idem, ibidem: "[...] e anchor che si facci più fiate uma historia, cosa vituperosa è il riporvi quelle istesse figure e atti [...]". Cf. Anexo, p. 50.
} 
pictórica ligada ainda a Giorgione via Girolamo Savoldo (atuante em 1508-1548) de quem foi discípulo, Pino não deixou de ser atento à nova tendência pictórica que surgia, denominada "Maneirismo", ao fazer uma observação sobre um de seus principais aspectos, a figura serpentinata. Assim, prescreve ao pintor que como parte da invenção ele deve representar uma figura em posição toda esforçada, misteriosa e difícil, a fim de que ele possa ser estimado enquanto virtuoso na sua arte. ${ }^{\mathbf{5 2}}$

Pino considera ainda invenção narrar a história com poucos personagens e orná-los com vários despojos, panos, ligames, laços, frisos, véus, armaduras, isto é, todo tipo de ornamento bizarro que crie na obra uma atmosfera grave, ao mesmo tempo graciosa que desperte admiração nos observadores e não o riso. ${ }^{\mathbf{5 3}}$

Em outras passagens de seu tratado, onde define a pintura como invenção, Pino afirma que "é a mais elevada invenção que se realiza entre os homens",54 e um pouco mais adiante, numa sentença um tanto obscura, ele diz que "ela é uma divina invenção cujo tema nos eleva à distinção dos dois mundos, conservando a memória dos homens ao revelar sua efígie". E ainda: "a pintura engrandece a fama dos virtuosos ao representar seus atos de outra forma que não com palavras, adornando-os de eterna glória, a tal ponto de estimular os pósteros a se lhes igualar em proeza". 55 Pino aconselha ao pintor inspirar-se nos poetas que introduzem em suas comédias ou outras suas obras uma determinada brevidade, a qual deve seguir o pintor, não pretendendo restringir todos os fatos do mundo na composição de um único quadro. ${ }^{56}$ Preceito influenciado pelas palavras de Daniello. ${ }^{57}$ Numa referência ainda à doutrina da unidade de ação aristotélica, Pino prescreve ao pintor o costume de

\footnotetext{
${ }^{52}$ Idem, ibidem: “[...] e in tutte l'opere vostre fateli intervenire almeno uma figura tutta sforciata, misteriosa e difficile, acciò che per quella voi siate notato valente da chi intende la perfettion dell'arte". Cf. Anexo, p. 50.

${ }^{53}$ Idem, ibidem: "[...] ben mi piace, che la dechiaratione del soggeto s' includi in poche figure, ornando con varie spoglie, panni, legami, nudi, freggi, veli, armature e altri ornamenti di capo bizarri, e gai, dando all'opere tal venustà e gravita, che rendino li riguardanti ammirativi [...]”.Cf. Anexo, p. 52.

${ }_{55}^{54}$ Idem, ibidem, p. 10: "Quest'è la più alta inventione, che s'opri tra gli huomini [...]".Cf. Anexo, p. 29.

${ }^{55}$ Idem, ibidem: "Questa è quella divina inventione, il cui soggetto s'inalcia alla distintione dei due mondi, che conserva la memória degli huomini, dimostrando l'effigie loro, ch'aggrandisce la fama agli vertuosi, componendo con altro, che con parole gli atti suoi freggiati d'eterna gloria, eccitando li posteri a ragualiarseli di prodezza". Cf. Anexo, p. 30.

${ }^{56}$ Idem, ibidem, p. 16: "[...] però util sarebbe osservare alcuni ordini eletti dagli altri poeti che scrivono, il quale nelle loro comedie, et altre compositioni vi introducono la brevità, il che debbe osservare il pittore nelle sue inventione, e non voler restringere tutte le fatture del mondo in un quadro [...]".Cf. Anexo, p. 51.

${ }^{57}$ DANIELLO, Poetica, p. 39 e 54. In BAROCCHI, Paola. Trattati del Cinquecento fra Manierismo e Controriforma. Bari: Gius. Laterza e Figli Editore, 1960, p. 411, nota 12: "La comedia oltre il termine di cinque atti non travalichi, né di qua da quello s'aresti"; "Bisogna che noi vediamo ancora d'esser nelle narrazion nostre brevi, aperti e probabili. Brevi saremo se quelle cose noi stimiamo esser più necessarie toccheremo e taceremo quelle che cosi necessarie non saranno, ma soverchie".
} 
pronunciar a um só momento ou ação única, os fatos que pretende narrar ao compor a sua história, constituindo-a com o menor número de personagens possível. ${ }^{\mathbf{5 8}}$ Nesse sentido, pensamos que a postura de cada personagem representada deva estar intrinsencamente ligada à ação principal da narrativa, criando uma unidade de ação tal, que extraindo-se uma sequer, o todo ficaria em desarmonia. As poucas figuras requeridas implicariam numa tentativa de dar maior clareza à composição no tocante à história contada pela pintura, e um número excessivo de personagens causaria confusão na mente do observador. ${ }^{\mathbf{5 9}}$

Segue-se em Lodovico Dolce o mesmo ponto de vista, dado que, em seu tratado, ele define invenção como a fábula ou história que o pintor deve eleger por si mesmo, ou que lhe é revelada por outros autores. ${ }^{\mathbf{6 0}}$ No procedimento da invenção estão inclusas ordem e conveniência ou decoro. ${ }^{61}$ Para Vasari, invenção igualmente requer conveniência. ${ }^{62} \mathrm{~A}$ ordem refere-se aos fatos reais sucedidos na história, que devem ser narrados em sua pintura apropriadamente como ocorreram. ${ }^{63}$ Este aspecto da ordem estaria ligado, tal como em Pino, à unidade de ação prescrita por Aristóteles. Se na poesia dramática esta doutrina implicaria dizer que os poetas deveriam unir juntamente, eventos que ocorreram em diferentes tempos no sentido de transformá-los uma única ação, provando não haver inconsistência entre eles, mas uma probabilidade de realização, ou verossimilhança, poderse-ia dizer que o pintor teria a mesma possibilidade de efetuar sua narrativa de modo de

\footnotetext{
${ }^{58}$ PINO, Paolo, op. cit., p. 17: "Usano ancho di far pronuntiare a un solo, tutto quello che si hà da dimostrare, così die fare il pittore, comporre (con l'aiuto del vivo) lui solo, e da sè senza altro latrocinio la sua historia. Et perchè ancho vogliano minor numero di personaggi, che puono". Cf. Anexo, p. 52. Cf. ARISTÓTELES, HORÁCIO, LONGINO. A Poética Clássica. São Paulo: Editora Cultrix, 1997, p. 28: "Portanto, assim como, nas outras espécies de representação, a imitação única decorre da unidade do objeto, é preciso que a fábula, visto ser imitação duma ação, ou seja duma única e inteira, e que suas partes estejam arranjadas de tal modo que, deslocando-se ou suprimindo-se alguma, a unidade seja aluída a transtornada; com efeito, aquilo cuja prsença ou ausência não traz alteração sensível não faz parte nenhuma do todo".

${ }^{59}$ Idem, ibidem, p. 17: “Onde Varrone non comportava, che ne' convivii publici vi si adunasse più di nove persone, perch'in vero tante figure anzi si può dir confusione, che compositione, non però intendo che questo numero di nove si debbi osservar da noi, ma più, et meno, come porta l'historia fuggendo il tumultuare [...]". Cf. Anexo, p. 52.

${ }^{60}$ DOLCE, Lodovico, op. cit. p. 164: "La invenzione è la favola o istoria, che il pittore se elegge da lui stesso ou gli è posta inanzi da altri [...]".Cf. Anexo, p. 111.

${ }^{61}$ Idem, ibidem, p. 164-165: "E cominciando dalla invenzione, in questa dico che vi entrano molte parti, tra le quali sono le principali l'ordine e la convenevolezza". Cf. Anexo, p. 112.

${ }^{62}$ VASARI, Giorgio, op. cit., p. 75: "Questa invenzione vuol in sé una convenevolezza formata di concordanza e d'obedienza: ché, s'una figura si muove per salutare un'altra, non si faccia la salutata voltarsi indietro, avendo a rispondere; e con questa similitudine tutto il resto".

${ }^{63}$ DOLCE, Lodovico, p. 166: "Quanto all'ordine, è mistiero che il pittore vada di parte in parte rassembrando il sucesso dell' istoria che ha presa a dipingere, così propriamente che i riguardanti stimino che quel fatto non debba essere avenuto altrimenti di quello che da lui è dipinto". Cf. Anexo, p. 113.
} 
representar fatos históricos de momentos diversos, transmutando-os numa unidade de ação, tempo e espaço em sua pintura, demonstrando serem estas ações terem ocorrido de maneira verossímil. $^{64}$ Acreditamos ser esta a afirmação de Dolce, no que diz respeito à ordem enquanto componente da invenção.

A conveniência ou decoro na teoria de Dolce refere-se à harmonia que deve haver entre as figuras representadas e suas expressões dos afetos, tanto fisionômicas, quanto no tocante aos movimentos corporais, em suas vestimentas, ofício e grau que personificam, pátria, costume, lugar, tempo, todos de acordo com as ações que realizam. ${ }^{65}$ Em trecho seguinte, ele afirma que a invenção decorre de dois momentos, da história e do engenho do pintor. Através da história, ele obtém simplesmente a matéria, e por intermédio do engenho, a ordem e a conveniência que procedem das atitudes, da variedade e da energia das figuras, que é parte comum ao desenho. ${ }^{66}$

A profunda engenhosidade do pintor quanto à invenção somente é passível de ser apreciada em sua totalidade, quando analisada em decorrência das inúmeras possibilidades de concepção narrativa de uma história. A história é portanto a parte mais importante da composição de uma obra pictórica, tal como o foi para a tragédia. Aristóteles afirmou na Poética que o elemento de maior relevância da tragédia é a "trama dos fatos", ou história a ser representada pelo ator, que se desenrola por meio da imitação de ações dos homens. ${ }^{67}$ Pino e Dolce o tomam enquanto paradigma para definir sua premissa. Duas outras de suas fontes apresentam o mesmo argumento. Horácio, que ao discutir seu conceito de invenção na Arte Poética, censura a criação de fatos inéditos e desconhecidos na poesia, aconselhando ao poeta a adotar temas que a tradição tornou familiar, seguindo o modelo de

\footnotetext{
${ }^{64}$ LEE, R. W., op. cit., p. 257: "[...] that Aristotle's doctrine of the unity of action is pronounced to be as valid for painting as for dramatic poetry, and that painting is virtually declared to be, like poetry, an art of time". "The Aristotelian theorist begins by observing that if the rules of the theatre allow poets to join together several events that happened at different times in order to make a single action of them, provided there be no inconsistency and that probability ("vraisemblance") be strictly observed, it is yet more right that the painter should have the same freedom [...]".

${ }^{65}$ DOLCE, Lodovico, op. cit., p. 182: "[...] perchè, quanto alla convenevolezza, si dee (come ho detto) conformar l'abito al costume delle nazioni e delle condizioni." Cf. Anexo, p. 128.

${ }^{66}$ Idem, ibidem, p. 171: "Per quello che s'è detto appare che la invenzione vien da due parti: dalla istoria e dall'ingegno del pittore. Dalla istoria egli ha semplicemente la materia, e dall'ingegno, oltre all'ordine e la convenevolezza, procedono l'attitudine, la varietà e la (per così dire) energia delle figure, ma questa è parte comune col disegno". Cf. Anexo, p. 118.

${ }^{67}$ ARISTÓTELES, op. cit., p. 75: "Porém o elemento mais importante é a trama dos fatos, pois a tragédia não é imitação de homens, mas de ações e de vida, de felicidade (e infelicidade; mas felicidade) ou infelicidade reside na ação, e a própria finalidade da vida é uma ação, não uma qualidade".
} 
perfeição dos escritores gregos. ${ }^{68}$ E Alberti, que no século anterior havia já apontado o elevado valor da história na obra pictórica, ${ }^{69}$ asseverando ser unicamente digno de honra o pintor que conseguisse narrá-la em sua obra, de tal maneira a torná-la um colosso, ${ }^{70}$ afirma também que obras históricas ou poéticas tomadas como estudos livres poderiam prover ao pintor inspiração para a criação de qualquer fábula antiga ou moderna, sacra ou profana.

A inventio é, portanto, para os dois autores, parte fundamental de ligação entre pintura, poesia e oratória, inserindo-se no plano geral de composição de ambas as artes, que por sua vez, assemelha-se à estrutura do discurso de um orador.

Devido à relevância da invenção-história para as duas artes, os teóricos do século XVI, inclusive Pino e Dolce, com o propósito de legitimar a doutrina do ut pictura poesis, instaram o pintor a tornar-se um homem letrado tanto quanto Cícero, no De Oratore, ou Quintiliano nas Instituições Oratórias, haviam exortado o orador a adquirir um adequado conhecimento de poetas e historiadores e a fruir do convívio com homens eruditos, sem os quais a concepção de uma invenção refinada em suas obras seria completamente impossível. De acordo com ele, o orador deveria ler poetas e se informar com histórias, estudos e aprender a distinguir os mestres e autores de cada excelente arte, em guisa de adquirir a prática de louvá-los, expô-los, corrigi-los, criticá-los e confutá-los. ${ }^{71}$ Em outro trecho ele havia afirmado que ninguém deveria ser denominado orador se não tivesse se aperfeiçoado em todas as artes que deveriam condizer a um orador de boa estirpe. ${ }^{\mathbf{7 2}}$ Seguindo o mesmo raciocínio, em Quintiliano encontramos a afirmação de que Teofrasto, em um de seus tratados retóricos perdidos, havia exposto que a leitura de poetas seria de grande serviço ao orador, uma vez que poetas poderiam tornar-se fontes de inspiração para os temas a serem argumentados pelos oradores, devido à grandiosidade da linguagem que

\footnotetext{
${ }^{68}$ HORÁCIO, op. cit., p. 75: "É difícil dizer com propriedade o que não pertence à tradição: melhor farás se o carme de Ílion em actos trasladares em vez de proferires, pela primeira vez, factos inéditos e desconhecidos". E pg. 95: "Quanto a vós, compulsai de dia e compulsai de noite os exemplares gregos".

${ }^{69}$ ALBERTI, op. cit. p. 91: "Sarà la storia qual tu possa lodare et maravigliare tale che con sue piacevolezze si porgierà si ornata et grata che ella terrà con diletto et movimento d'animo qualunque dotto o indotto la miri".

${ }^{70}$ Idem, ibidem, p. 85: “Grandissima opera del pittore sarà l'istoria [...]”. E p. 87: "Grandíssima opera del pictore con uno colosso; ma istoria, maggiore loda d'ingegnio rende l'istoria che qual sia colosso".

${ }^{71}$ CICERO, op. cit., p. 109: "We must also read the poets, acquaint ourselves with histories, study and peruse the masters and authors in every excellent art, and by way of practice praise, expound, emend, criticize and confute then".

${ }^{72}$ Idem, ibidem, p. 53: "[...] my opinion is this, that no one should be numbered with the orators, who is not accomplished in all those arts that befit the well-bred."
} 
utilizavam e por seu poder de estimular todo tipo de emoções e seu apropriado tratamento de caráter, ao mesmo tempo em que a leitura de obras poéticas pelo orador poderia servir como uma espécie de descanso e um agradável estudo para mentes esgotadas, devido ao desgaste diário das cortes. ${ }^{73}$ Em outro trecho, Quintiliano afirmou ainda que a história poderia igualmente prover o orador tal como o faz um alimento, salientando porém, que o orador deveria se abster de muitas das excelências pertinentes ao historiador. Como por exemplo, o fato da história ser escrita com o propósito de ser uma narrativa, e não construir argumentos para se obter provas. Ou de ser ainda esquematizada por um começo e por um fim e não criada para surtir um efeito ou necessidade imediatos de uma contenda forense, mas para recordar eventos que serviriam ao benefício da posteridade e por conseqüência conferir glória ao seu autor. ${ }^{74}$

No que diz respeito ao pintor dever tornar-se um letrado tanto quanto o poeta, Pino, retomando a prescrição de Quintiliano, faz a seguinte declaração: “é necessário que o pintor nasça como os poetas". ${ }^{75}$ Para ser um excelente pintor não basta apenas estudo, é preciso ter a natureza aliada ao talento. E, quase que com as mesmas palavras de Cícero, ele assevera "ser conveniente que o pintor seja dotado de grande juízo, ao menos de letras, a fim de que seja hábil na língua latina e no idioma vulgar, por meio das quais poderá se prevalecer das histórias e invenções antigas". ${ }^{76}$ Alberti, numa mesma chave, declara que o pintor deva ser um homem douto em boas letras. ${ }^{77}$ Dolce, por sua vez, afirma também que:

\footnotetext{
${ }^{73}$ QUINTILIAN, op. cit., p. 17, 19: "Theophrastus says that the reading of poets is of great service to the orator, and has rightly been followed in this view by many. For the poets will give us inspiration as regards the matter, sublimity of language, the power to excite every kind of emotion, and the appropriate treatment of character, while minds that have become jaded owing to the daily wear and tear of the courts will find refreshment in such agreeable study."

${ }^{74}$ Idem, ibidem, p. 19, 21: "History, also, may provide the orator with a nutriment which we may compare to some rich and pleasant juice. But when we read it, we must remember that many of the excellences of the historian require to be shunned by th orator. For history has a certain affinity to poetry and may be regarded as a kind of prose poem, while it is written for the purpose of narrative, not of proof, and designed from beginning to end not for immediate effect or the instant necessities of forensic strife, but to record events for the benefit of posterity and to win glory for its authors".

${ }^{75}$ PINO, Paolo, op. cit., p. 21: "Oh, non sapete voi? Chi vi bisogna nascere come i poeti [...]".Cf. Anexo, p. 62.

${ }^{76}$ Idem, ibidem, p. 31: "Convien adunque, ch'in lui sia tanto giudicio di littere almeno, che sia capace della língua latina e ami la volgare, per lo mezzo delle quali si potrà prevalere dell'historie e inventioni antiche".

${ }^{77}$ ALBERTI, Leon Battista, op. cit., p. 103-104: "Ma piacerammi sia il pittore, per bene potere tenere tutte queste cose, huomo et docto in buone lettere [...]".Cf. Anexo, p. 89.
} 
"é impossível ao pintor dominar as partes que convenham à invenção, sejam por conta da história como da conveniência, senão for prático das histórias e das fábulas dos poetas. Assim como é de grande utilidade a um letrado, pelas coisas que pertencem ao ofício do escrever, o saber desenhar, do mesmo modo seria benéfico à profissão do pintor, o conhecer as letras. Mas não sendo o pintor letrado, que conheça ao menos histórias e poesias, mantendo a prática dos poetas e dos homens doutos". ${ }^{78}$

Em outro trecho de seu diálogo, Lodovico chega inclusive a argumentar que poetas também poderiam ser influenciados pela obra de pintores, ao escrever que a pintura realizada por Rafael figurando Alexandre e Roxana poderia lembrar uma descrição da cena feita por Luciano, ou mesmo o Laocoonte de Virgílio que fora inspirado em esculturas de artífices rodienses. ${ }^{79}$ Além de Cícero e Quintiliano em seus preceitos ao orador dever tornar-se douto, Daniello também aconselha ao poeta obter conhecimento de todas as ciências e doutrinas, ao menos da maior parte delas. E não sendo perfeito teólogo ou filósofo ao menos saiba os princípios da filosofia moral e natural. ${ }^{\mathbf{8 0}}$

Após discorrermos sobre a invenção que se realiza na história criada por um pintor letrado, a essência da pintura e da poesia restaria na expressão dos afetos, por ser este um dos aspectos ligados à função primordial das duas artes, o comover, acima do doutrinar e deleitar. Vimos referido acima que, já no século XV, Leonardo ${ }^{\mathbf{8 1}}$ e Alberti $^{\mathbf{8 2}}$ expuseram em

\footnotetext{
${ }^{78}$ DOLCE, Lodovico, op. cit. p. 170: "Et è impossibile che il pittore possegga bene le parti che convengono alla invenzione, sì per conto della istoria come della convenevolezza, se non è pratico delle istorie e delle favole de'poeti. Onde, sì come è di grande utile a um letterato, per le cose che appartengono all'ufficio dello scrivere, il sapere disegnare; così ancora sarebbe di molto beneficio alla profession del pittore il saper lettere. $\mathrm{Ma}$, non essendo il pittor letterato, sia almeno intendente, come io dico, delle istorie e delle poesie, tenendo pratica di poeti e d'uomini dotti". Cf. Anexo, p. 117.

${ }^{79}$ Idem, ibidem, op. cit., p. 192: “[...] se Rafaello l'avesse tolta da'libri di Luciano o Luciano dalle pitture di Rafaello; se non fosse che Luciano nacque più secoli avanti. Ma che è perciò? Anco Virgilio discrisse il suo Laocoonte tale quale l'aveva prima veduto nella statua di mano dei ter artefici rodiani, la quale com istupor di tutti oggidì ancora si vede in Roma". Cf. Anexo, p. 137.

${ }^{80}$ DANIELLO, Bernardino, op. cit., p. 7: "Essendo, adunque, non solamente l'umane operazioni tutte ma le cose divine ancora allo scrittore soggetto, fà di mestieri che egli abbia eziandio cognizione se non di tutte le scienze e dottrine, almeno della maggior parte. E non essendo egli perfetto teologo e filosofo, abbia i principii almeno della sovranaturale, naturale e morale filosofia. Conciò sia cosa che il sapere è principio e fonte dello iscriver bene e dirittamente le cose, e la filosofia sola à quella che ne può amministrar gli altri concetti e le belle invenzioni".

${ }^{81}$ LEONARDO, Trattato Della Pittura, p. 285. In LEE, R. W., op. cit., p. 219, nota 101: "et ancora ti ricordo ...et sopra tutto, che li circonstanti al caso, per il quale è fatta la storia, sieno intenti a esso caso, com atti che
} 
seus tratados, a habilidade do pintor, similar ao do poeta de representar as paixões da alma, que somente se manifestam por meio do movimento dos corpos. ${ }^{83}$

Em se tratando da oratória, os estudiosos afirmam que a eficácia dessa arte derivava de seu poder sobre as emoções dos homens. Segundo Brian Vickers, os retóricos da Renascença deram enorme atenção a este tópico, porque o relacionavam à "vontade humana" como fonte de liberdade e responsabilidade. De acordo com eles, o termo retórico muovere era cada vez mais concebido como fator mobilizador da vontade para bons propósitos. ${ }^{84}$ O humanista Coluccio Salutati, Chanceler de Florença, chegou a defender a preeminência da vontade sobre o intelecto. ${ }^{\mathbf{8 5}}$ Poderíamos dizer que o estímulo das paixões por meio da comoção afetaria o julgamento das pessoas, as quais por conseguinte seriam capazes de direcionar suas vontades. No período da Renascença, em que o homem descobre-se e volta-se para si mesmo, o despertar dos afetos e sua intrínseca relação com o juízo e a evolução da força de vontade, tornaram-se fontes de energia propulsora para o desenvolvimento da auto-determinação que culminou no surgimento e formação das grandes personalidades individuais daquele momento, representados por grandes ícones como Alberti e Leonardo e muitos outros homens notáveis que a eles se seguiram.

A pintura, a par da retórica e da poética, assumiu igualmente o objetivo de comover os homens às paixões. Por suas imagens incitarem aos sentimentos, ela tornou-se, no período da Contra-forma, artifício religioso de doutrinação e comoção dos ignaros por representar históricas bíblicas e servir para levá-los à devoção e à submissão dos propósitos da igreja cristã.

Na Poética, de Aristóteles, observamos que, se os seres humanos em ação são o tema primeiro da poesia e conseqüentemente da pintura, segue-se que os movimentos do

mostrino admiratione, riverentia, dolore, sospetto, paura, guaudio, o' secondo che richiede il caso, per il quale è fatto il congionto o' vero concorso delle tue figure".

${ }^{82}$ ALBERTI, op. cit., p. 93: "Poi moverà l'istoria l'animo quando li huomini ivi dipinti molto porgeranno suo movimento d'animo".

${ }^{83}$ Idem, ibidem, p. 93: "Ma questi movimenti d'animo si conoscono daí movimenti del corpo". LEONARDO, Trattato della Pittura, p. 385. In LEE, R. W., op. cit., p. 219, nota 103: "Deli quai pianti alcuno si dimostra disperato, alcuno mediocre, alcuni solo lacrimosi, et alcuni gridano, alcuni col viso al cielo e co'le mani in basso, havendo le dita di quelle insieme tesute, altri timorosi, co'le spalli inalzate àgli orecchi, et così seguono secondo le predette cause. Quel, che versa il pianto, alza le ciglia nelle loro gionture et le stringie insieme, e compone grinze disopra in mezo li canti della bocca in basso; et colui che ride gli há alti, et le ciglia aperte et spatiose".

${ }^{84}$ VICKERS, Brian, op. cit., p. 276.

${ }^{85}$ Idem, ibidem, p. 277. 
corpo que expressam os afetos e as paixões da alma são o espírito e a vida da arte e o objetivo para o qual toda ciência da pintura deve propender, ${ }^{86}$ o mesmo podendo-se dizer dos traços fisionômicos das figuras representadas. Quanto às três funções, comover, doutrinar e deleitar, Cícero afirmava que ensinar é dever, deleitar é honra, comover, necessidade. ${ }^{87}$ Tal como a arte oratória que, enquanto instrumento do orador na cena forense da Antiguidade, concedia-lhe ferramentas argumentativas que lhe permitia incitar o público às emoções para alcançar o objetivo de vencer sua causa, devendo-se o resultado do discurso, à eloqüência com que proferia as palavras tanto pela entonação da voz, a pronuntiatio, quanto pelo movimento do corpo e gestos, a actio, acrescido pelas expressões fisionômicas inerentes, a pintura, para equiparar-se às duas artes, poesia e retórica, adotou o mesmo fim. E para atingir o âmago do observador, o pintor deveria seguir os conselhos de Cícero, ${ }^{88}$ Horácio $^{89}$ e Daniello ${ }^{90}$ concordes entre si, ao prescrever que, para que poeta e pintor pudessem incitar nos outros as paixões por eles descritas ou pintadas, deveriam primeiramente terem-nas vivenciado.

Pino e Dolce conferem igualmente grande ênfase na função do comover pela representação das paixões da alma. Vimos acima as palavras de Pino sobre o fato das figuras representadas deverem ser copiosas e variadas em seus movimentos e posturas do corpo, a fim de expressar os afetos do ânimo. Para tanto, ele não deixou em seu tratado de apontar a importância ao pintor do estudo da fisiognomonia, tomando como exemplo as obras de um pintor antigo de nome Demones Lacedemones, cujas pinturas eram tão semelhantes ao verdadeiro, que nelas podia-se reconhecer um homem avaro, um cruel, um

\footnotetext{
${ }^{86}$ LEE, R. W., op. cit., p. 217.

${ }^{87}$ CÍCERO, Marco Túlio. De Optimo Genere Oratorum. Tradução Luiz Marques: "Pois é o melhor o orador que, com falar, ensina, deleita e comove o ânimo dos ouvintes. Ensinar é dever, deleitar é honra, comover, necessidade. Deve-se conceder que um faz estas coisas melhor que outro; mas isto ocorre, na verdade, não por diferença de gênero, mas de grau. O melhor, de fato, é único; e o que mais dele se aproxima é o que mais se lhe assemelha; de onde se evidencia que o pior seja o que mais se lhe desassemelhe".

${ }^{88}$ CICERO, op. cit., p. 333: "Moreover it is impossible for the listener to feel indignation, hatred or ill-will, to be terrified of anything, or reduced to tears of compassion, unless all those emotions, which the advocate would inspire in the arbitrator, are visibly stamped or rather branded on the advocate himself".

${ }^{89}$ HORÁCIO, op. cit., p. 71: "Não basta que os poemas sejam belos: força é que sejam emocionantes e que transportem, para onde quiserem, o espírito do ouvinte. Assim como o rosto humano sorri a quem vê rir e aos que choram se lhes une em pranto, também se queres que eu chore, hás-de sofrer tu primeiro: só teus infortúnios podem comover-me, quer sejas Telefo quer Peleu; se, porém, recitares mal o teu papel, dormitarei ou cairei no riso".

${ }^{90}$ DANIELLO, Bernardino, op. cit., p. 40. In LEE, R. W. op. cit., p. 218, nota 92: "Ne potrete voi ciò fare giamai se gli animi vostri non siano dentro commossi et infiammati prima".
} 
vicioso. ${ }^{91}$ Ainda em sua opinião, a pintura é capaz de distinguir os efeitos amorosos, revelar a falsa adulação, o fogo do desdém, o vivo da força, o grave da fadiga, o terrível do medo, a piedade por natureza, o intrínseco do ânimo, a engenhosidade da arte, a vida e a morte.92 Porém, pintura detém o poder de levar ao riso e à zombaria dos circunstantes, caso o pintor represente suas figuras desproporcionadas e desprovidas de graça. ${ }^{\mathbf{9 3}}$

Lodovico Dolce, na linha de pensamento apontada por Cícero, Horácio e Daniello, afirma ser necessário que as figuras comovam os ânimos dos observadores, algumas inquietando-os, outras alegrando-os ou incitando-os à piedade e outras ao desdém, segundo a qualidade da história. Um vez que, se às coisas escritas ou declamadas, carecerem da capacidade de despertar a comoção, serão também destituídas de espírito e de vida. Reiterando as mesmas palavras dos três já referidas acima, Dolce declara não ser capaz de comover com suas obras o pintor que não sentir em sua alma as mesmas paixões, ou afetos, que pretende imprimir no ânimo de outrem. ${ }^{94}$ Em outras passagens, ele assevera que, embora o pintor não possa representar as coisas que se submetam ao tato, como a frieza da neve ou então as coisas que são inerentes ao gosto, como a dulcilidade do mel, ele tem, contudo, a habilidade de figurar os pensamentos e os afetos do ânimo, ${ }^{95}$ tais como alegria, dor, ira, temores, esperanças e desejos, numa declaração muito similar à de Pino. E uma vez que o pintor seja definido enquanto poeta mudo, assim como muda era denominada a

\footnotetext{
${ }^{91}$ PINO, Paolo, op. cit., p. 32: "Parte honorata e utile del nostro pittore sarebbe la fisiognomia, come ancho vuol Pomponio Gaurico, acciò che se volesse dipignere uma femina casta, sappi molto bene distinguere li contorni, e applicare l'effigie secondo la qualità delle cose, imitando quel Demone Lacedemone pittore, le pitture del qual'erano tanto simili al próprio, ch'in quello si conosceva un'avaro, un crudele, un vitioso e tutte altre proprietà naturali”. Cf. Anexo, p. 89.

${ }_{92}$ Idem, ibidem, pg. 10: "La pittura distingue gli effetti amorosi, scuopre la falsa adulatione, il fuoco dell sdegno, il vivo della fortezza, lo grave della fatica, il terribile della paura, la pietà di natura, l'intriseco dell'aio, l'ingeniosità dell'arte, et ch' è più, la vita, et la morte". Cf. Anexo, p. 31.

${ }^{93}$ Idem, ibidem, p. 17: “[...] imperochè mal è per l'artefice, se l'opera muove allo riso li circostanti, perchè si stupisce del bene, e si burla del sportionato e goffo". Cf. Anexo, p. 52.

${ }^{94}$ DOLCE, Lodovico, op. cit., p. 186: "Questo è che bisogna che le figure movano gli animi de' riguardanti, alcune turbandogli, altre rallegrandogli, altre sospingendogli a pietà et altre a sdegno, secondo la qualità della istoria. [...] perchè questo è il condimento di tutte le sue virtù, come aviene parimente al poeta, all'istorico et all'oratore [...]. Né può movere il pittore, se prima nel far delle figure non sente nel suo animo quelle passioni, o diciamo affetti, che vuole imprimere in quello d'altrui. Onde dice il tante volte allegato Orazio: "Se vuoi ch'io pianga, è mestiero che tu avanti ti dolga teco". Cf. Anexo, p. 131-132.

95 Idem, ibidem, p. 152: "Puossi ben dire che, quantunque il pittore non possa dipinger le cose che soggiacciono al tatto, come sarebbe la freddezza della neve, o al gusto, come la dolcezza del mele; dipinge non di meno i pensieri e gli affetti dell'animo". Cf. Anexo, p. 102.
} 
pintura, ele deve representar figuras que falem, gritem, chorem, riam e realizem de modo semelhante acontecimentos efetivos. ${ }^{96}$

Contudo, além do comover, a poesia deve ter por fim, segundo Horácio, igualmente o instruir e o deleitar. ${ }^{97}$ Os teóricos do XVI preceituaram o mesmo para a pintura. Nos tratados de Pino e Dolce, a prescrição da pintura enquanto doutrina aparece de modo implícito nas passagens em que ambos tratam do decoro, quando instruem os pintores nos vários procedimentos inerentes às muitas possibilidades de representação das figuras.

Já a função da pintura enquanto deleite manifesta-se de modo mais claro em ambos os autores. De acordo com Pino todos os artífices amam as obras da natureza, porque ela imita a si mesma imprimindo diversas formas nos mármores, troncos, fumaças ou nuvens, causando deleite em seu observador. ${ }^{98} \mathrm{O}$ deleite está intrinsecamente relacionado à copiosidade e variedade com que as figuras narram a invenção da história. Segundo Alberti, são esses dois elementos que atribuem voluptuosidade à pintura' ${ }^{99}$ e o quanto ela se torna agradável quando apresenta uma grande variedade de figuras em diferentes movimentos. 100

Para Dolce, a pintura é útil, deleitável e de ornamento. ${ }^{101}$ Em outra passagem ele afirma que, quanto ao deleite, acrescenta que não existe algo que tanto tenha por costume comover a si e alimente aos olhos dos observadores, quanto faz a pintura, nem mesmo as

\footnotetext{
${ }^{96}$ Idem, ibidem, p. 153: "Ma gli occhi sono principalmente le fenestre dell'animo et in questi può il pittore isprimere acconciamente ogni passione: come l'allegrezze, il dolore, l'ire, le teme, le speranze et i disideri. Ma pur tutto serve all'occhio de'riguardanti". "Dirò ancora che, se bene il pittore è diffinito poeta mutolo, e che muta si chiami altresì la pittura; sembra pure, a un cotal modo, che le dipinte figure favellino, gridino, piangano, ridano e facciano così fatti effetti”. Cf. Anexo, p. 103.

${ }^{97}$ HORÁCIO, op. cit., p. 105-107: "Os poetas ou querem ser úteis ou dar prazer ou, ao mesmo tempo, tratar de assunto belo e adaptado à vida. [...] As tuas ficções, se queres causar prazer, devem ficar próximas da realidade e não se pode apresentar tudo aquilo em que a fábula deseja que se creia [...]. Recebe sempre os votos, o que soube misturar o útil ao agradável, pois deleita e ao mesmo tempo ensina o leitor: é este o livro que dá dinheiro aos Sócios, que passa os mares e oferece ao célebre escritor imortal renome".

${ }^{98}$ PINO, Paolo, op. cit., p. 14-15: "Cotesto è chiaro, perchè la natura imita se stessa, et naturalmente tutti gli artefici amano le sue fatture e molte fiate la natura lo dimostra, dipingendo da se stessa nei marmi e tronchi diverse forme figurate, si ancho nel fumo e nube diversamente concernesi e questo fà la natura con quella dilettatione, che prende uno vedendo l'effigie sua nello specchio". Cf. Anexo, p. 45.

${ }_{99}$ ALBERTI, op. cit., p. 91: "Sarà la storia qual tu possa lodare et maravigliare tale che com sue piacevolezze si porgerà si ornata et grata che ella terra com diletto et movimento d'animo qualunque dotto o indotto la miri. Quello che prima dà voluptà nella istoria viene dalla copia et varietà delle cose".

${ }^{100}$ Idem, ibidem, p. 92: "Ma in ogni storia la varietà sempre fu ioconda et inprima sempre fu grata quella pittura in quale sieno i corpi com suoi posari molto dissimili".

${ }^{101}$ DOLCE, Lodovico, op. cit., p. 161: "Veggiamo ora quanto la pittura sia utile, dilettevole e di ornamento". Cf. Anexo, p. 109.
} 
gemas ou o próprio ouro o conseguem. ${ }^{102}$ Em novo momento mais à frente, ele declara que, sendo a pintura encontrada principalmente para deleitar, se o pintor não despertar o deleite, dela será obscuro e sem nome. E equiparando o deleite de uma pintura com uma poesia, Dolce assevera que o deleite deve crescer proporcionalmente às inúmeras vezes em que se contempla uma pintura, tal como ocorre nos bons poemas, os quais, quanto mais se lê, tanto mais deleitam e incitam o desejo de voltar a relê-lo. ${ }^{103}$

Outro aspecto de importância que se observa na relação entre pintura e poesia, assumidos pelos teóricos do século XVI em suas prescrições ao pintor, encontrava-se no aspecto da conveniência ou decoro, já mencionado anteriormente. Aconselhava-se a ele que as figuras em suas obras deveriam ser representadas de modo adequado quanto à idade, sexo, tipo de pessoa segundo seu caráter, expressos pelo movimento do corpo, gestos, posturas e expressões fisionômicas que definissem seu comportamento. Devendo todos serem apropriados ao tipo de ação realizado na história narrada pela pintura. Encontramos esse preceito em Horácio. ${ }^{104}$ na Poética de Daniello. ${ }^{105}$ Em Pino, encontramos algumas referências à conveniência tratada acima, bem como em Dolce, que além do já comentado, o demonstra igualmente em extensas passagens, quando, por exemplo, salienta a importância do docoro nas argumentações sobre o homem vestido e o nu, o corpo delicado em detrimento ao musculoso e sobre o movimento das figuras estar de acordo com as ações que realizam.

Uma última consideração a ser feita no tocante a um cotejo entre pintura e Arte Retórica encontra-se na partição que ambos os tratadistas realizaram desta arte equiparando-a aos elementos do discurso.

\footnotetext{
${ }^{102}$ Idem, ibidem, p. 163: "Quanto al diletto, benchè ciò si possa comprender dalle cose dette inanzi, aggiungo che non è cosa che tanto soglia tirare a se e pascer gli occhi de' riguardanti, quanto fa la pittura; non le gemme, non l'oro istesso". Cf. Anexo, p. 110.

${ }_{103}$ Idem, ibidem, p. 181: "Perciochè, essendo la pittura trovata principalmente per dilettare, se il pittore non diletta, se ne sta oscuro e senza nome. E questo diletto non intendo io quello que pasce gli occhi del volgo, o anco degl'intendenti, la prima volta, ma quello che cresce quanto più l'occhio di qualunque uomo ritorna a riguardare; come ocorre ne'buoni poemi, che, quanto più si leggono, tanto più dilettano e più accrescono il desiderio nell'animo altrui di rileggere le cose lette". Cf. Anexo, p. 127.

${ }^{104}$ HORÁCIO, op. cit., p. 79-81-83.

${ }^{105}$ DANIELLO, op. cit., p. 35 e ss. In LEE. R. W., op. cit., p. 229, nota 145: "Ne è solamente da vedere che le parti delle materie che si prendono a trattare, habbiano fra loro convenientia: ma che quelle anchora che alle persone si mandano, convenientissime, proprie, et accomodore siano. Et oltre acciò, che il parlar che sì da loro, sia di soavità, di mansuetudine, di gravità, d'allegrezza, di dolore, et finalmente pieno degli affetti tutti, secondo però la qualità, la degnità, l'habito, l'ufficio et l'età di ciascuna ... Et perchè questa convenevolezza non è altro che um cotal habito et proprietà dell'animo, è necessario che devendosi essa a ciascuna persona attribuire, si sappi somigliantemente et si conosca la consuetudine, et i costumi di ciascuna età".
} 
No tratado de Pino a pintura consta de três partes: desenho, invenção e colorido ${ }^{\mathbf{1 0 6}}$. A primeira delas, o desenho, decompõe-se ainda em outras quatro partes: juízo, circunscrição, prática e composição. ${ }^{107}$ Quanto ao Juízo, Pino declara ser conveniente que o pintor tenha a natureza, os fatos propícios e tenha sido gerado com a disposição dos poetas. ${ }^{108}$ Sendo juízo um termo de suma relevância na literatura artística, é necessário tecer algumas considerações a respeito.

De acordo com Jean Rouchette, o retto giudizio é uma faculdade, misto de qualidade natural e razão do homem que tem a capacidade de colocar barreiras às fantasias excessivas criadas pelo pintor, que resultem tanto de seu intelecto como as que possam advir da natureza. ${ }^{109}$

Segundo Robert Klein, o juízo não representava no Renascimento uma faculdade de ordem puramente intelectual; sua abrangência situava-se num campo que ficava entre o intelecto e os sentidos, estabelecendo laços entre o particular sensível e o universal inteligível ou vice-versa. O termo é análogo à aestimativa dos animais, ou seja, ao potencial

\footnotetext{
${ }^{106}$ Segundo Paola Barocchi esta subdivisão da pintura por Pino foi fundamental para a tratadística do século XVI. Alguns críticos defendem que Pino a derivou de Alberti, efetivando porém, algumas modificações com a intenção de romper com o rigor lógico e científico do humanismo florentino. Cf. ORTOLANI S. Le origini della critica d'arte a Venezia, "L'Arte", XXVI, 1923, pp. 13 sg., citado por BAROCCHI, Paola, op. cit., p. 408, nota 7. Outros críticos como Creighton Gilbert apontam divergências entre os dois autores. Além de Pino e Alberti, Francesco Lancillotti, que publicou seu Trattato della Pittura, em versos, em Florença, no ano de 1509, havia utilizado esta divisão. Ettore Camesasca, também citado por Barocchi, afirma que devido à obscuridade do texto de Lancillotti, a divisão feita por Pino talvez obedeça a classificações retóricas, em consonância com os inúmeros tratados de Retórica e Poética surgidos no XVI. Vide as afirmações de Bernardino Daniello em sua "Poética" surgida em 1536: "Adunque dalla prima di queste tre parti [della poesia: cioè invenzione, disposizione ed elocuzione] incominciando, dico niuna materia esser, com'alcun crede, ad esso poeta determinada; anzi essergli conceduto ampia licenza - sì come ancora è al dipintore, di finger molte e diverse cose diversamente - di potere di tutte quelle cose che in grado li siano, ragionare et iscrivere". Palavras muito próximas aos conselhos de Horácio aos Pisões.

${ }^{107}$ PINO, Paolo, op. cit., p. 15: “[...] dividerò (la pittura) in tre parti à modo mio, la prima parte sarà disegno, la seconda inventione, e la terza e ultima, il colorire. Quanto alla prima parte detta disegno, io voglio ancho dividerla in quattro parti, la prima diremo giudicio, la seconda circuscrittione, la terza pratica, l'ultima retta compositione". Cf. Anexo, p. 45-46.

${ }^{108}$ Idem, ibidem, p. 15: "Circa alla prima detta da me giudicio, in questa parte ci conviene haver la natura e i fatti propicii, et nascere com tal dispositione, come i poeti, altro non conosco, come tal giudicio se Possi imparare, è bem vero, ch' isercitandolo nell'arte, egli divien più perfetto [...]”.Cf. Anexo, p. 46.

${ }^{109}$ ROUCHETTE, JEAN. La Renaissance que nous a Léguée Vasari. Paris, Société D’Édition "Les Belles Lettres", 1959, p. 95-96: "Le retto giudizio: On sent, à maintes reprises, le désir de mettre des garde-fous aux fantaisies excessives de l'homme ou de la nature. Il ne faut pas - comme Piero di Cosimo ou Bartolomeo de Bagna-cavallo - copier le bom, le mauvais et l'extravagant. Il est vain de mûrir les fruit d'une fantaisie déréglée. Nature e Raison, celle-ci appelée souvent "retto giudizio", se corrigent mutuellement, pour constituer ce que notre XVIIe. Siècle appela le "vraisemblable". Vasari n'est pas un censeur aussi intransigeant que Boileau. Il admet dans la pratique l'extravagant, le fantastique, à condition que les autres lois esthétiques soient respectées".
} 
de "julgar instintiva ou afetivamente as coisas e as sensações. O juízo nesse período tinha por significado o processo mental de reação imediata ao mundo perceptível, não devendo ser confundido com uma proposição deduzida de outras anteriores, e essa reação seria tão imediata que se poderia explicitá-la por meio da razão. Entre as faculdades coligadas ou assimiladas ao judicium, Klein aponta as variações cogitativa, scrutinium, imaginativa, discretio. Declara ainda que a discretio, veio a substituir giudizio na Veneza do século XVI:

"É significativo que na teoria da arte discrezione tenda a substituir giudizio no meio veneziano de 1550 , isto é, no exato momento do antiacademismo inspirado por Aretino: os autores então repetiam que não se deve aplicar cegamente os canônes vitruvianos a todas as figuras de um desenho, mas que se deve adaptá-los à situação com giudizio e discrezione - esses termos eram, segundo Pino e Dolce, sinônimos". 110

Juízo no tratado de Paolo Pino adquire as acepções propostas por Klein. Num primeiro momento Pino associa juízo a um talento inato ao pintor que se desenvolve com a prática do ofício: "acerca da primeira parte denominada por mim juízo, é conveniente ter a natureza e os fatos propícios e nascer com tal disposição, como os poetas. Não conheço outro modo através do qual seja possível aprendê-lo. É bem verdade que, ao exercitá-lo na arte ele virá a ser mais perfeito". Numa segunda instância, ao argumentar que se deve utilizar com cautela o cânone de proporção vitruviano, Pino equipara juízo à discretio no sentido de um discernimento que é quase uma faculdade intuitiva, ou então um senso de medida ligado ao raciocínio e na qual o artífice serve-se de regras e proporções: ${ }^{111}$

"os antigos engenhosos elegeram entre os homens uma dessas quantidades como a mais proporcionada e justa e destinaram eles que o homem fosse da altura de seis pés e esta é a ordem usada por Vitrúvio. Mas é de se crer que

\footnotetext{
${ }^{110}$ KLEIN, Robert. A Forma e o Inteligivel. São Paulo, EDUSP, 1998, p. 333-334.

111 Segundo Luigi Grassi, juizo na literatura artística é compreendido como critério, senso de "medida", "raciocínio" de um artista, no ato da realização da obra, com o auxílio de regras, proporções e instrumentos. Cf. GRASSI, Luigi e PEPE, Mario, op. cit., p. 359: "Nella letteratura artistica il Giudizio va inteso come critério, senso di 'misura', 'ragionamento' di um artista, avanti o nell'atto di realizzare la própria opera, giovandosi di regole, proporzioni, strumenti; od anche: di um artista o di chiunque giudica le opere altui".
} 
Vitrúvio entendesse pés geométricos, os quais segundo Marco Varrão e Aulo Gelo tinham quatro palmos de mão, porquanto os pés comuns falham bastante em muitas formas proporcionadas. Mas aqui nos ocorre a discrição, que é entendida por mim como o bom juízo". 112

Por fim, Pino coliga a acepção de juízo ao gosto ao afirmar que, inúmeros são os juízos e as constituições físicas, de forma que cada um extrai o gosto a partir de seu intelecto: "vários são os juízos humanos, diversas as compleições, temos extraído do intelecto o gosto, do mesmo modo de um e de outro, cuja diferença causa o que não agrada igualmente a todos". 113

No diálogo de Dolce o termo adquire a semelhante conexão proposta por Pino, ou seja, juízo associa-se a discretio. Dolce o cita quando trata da figuração em escorços, declarando que tal artifício não deve ser realizado sem juízo ou discrição: “acontece ainda que as figuras, todas ou alguma parte delas devam ser representadas em escorço, algo que não pode ser efetuado sem grande juízo e discrição". ${ }^{114}$

No que concerne aos outros elementos do desenho, vemos que, de acordo com Pino, circunscrição representa o "perfilar", o contornar as figuras e dar-lhes claros e escuro. ${ }^{115}$ Adquire o sentido de um primeiro esquema da obra, do esboço preliminar. ${ }^{116}$ A prática

\footnotetext{
${ }^{112}$ PINO, Paolo, op. cit., p. 8: "[...]gli antichi ingeniosi elessero tra gli huomini una di queste quãtità per più proportionata, e giusta, e volsero costoro, che l'huomo fusse d'altezza di sei piedi, e quest'è l'ordine usato da Vitruvio, ma è da credere, che Vitruvio intendesse de piedi geometrici, i quali secondo Marco Varrone e Aulo Gellio erano di quattro palmi di mano, imperò che li piedi comuni fallano assai in molte forme proportionate. Ma qui ci concorre la discrettione, ch'è intesa da me per buon giudicio”. Cf. Anexo, p. 23.

113 PINO, Paolo, op. cit., p. 28: "Sono varii li giudicii humani, diverse le complessioni, habbiamo medesmamente l'uno dall'altro estratto l'intellectto nel gusto, la qual differentia causa, che non à tutti aggradano equalmente le cose". Cf. Anexo, p. 83.

${ }^{114}$ DOLCE, Lodovico, op. cit., p. 180: "Aviene ancho che le figure, o tutte o alcuna parte di esse, scortino. La qual cosa non si può far senza gran giudizio e discrezione”. Cf. Anexo, p. 126.

${ }^{115}$ Luigi Grassi, também observou que a definição que Pino estabelece de circunscrição, é já um desenho pictórico, porque ele abrange não somente o contorno da superfície ou limite externo da imagem, mas igualmente o preenchimento de claros-escuros . [o que permite visualizar um esboço da completude da obra]. Cf. I concetti di schizzo, abbozzo, macchia "non finito" e la costruzione dell'opera d'arte, in "Studi in onore di Pietro Silva", Florença, 1957, p. 100, citado por BAROCCHI, Paola, op. cit., p. 409, nota 2 referente à p. 114 do texto original de Pino: "Prima ancora del Vasari, a Venezia Paolo Pino ravvisò nello "schizzo", un disegno già pittorico, in quanto comprende non solamente il contorno, o limite esterno dell'immagine [...]".

${ }^{116}$ PINO, Paolo, op. cit., p. 15: "[...] ma havendo il giudicio, voi imparerete la circoscrittione, il ch'intendo che sia il profillare, contornare le figure e darle chiari e scuri à tutte le cose, il qual modo voi l'addimandate schizzo". O sentido de circunscrição em Pino difere quanto ao proposto por Alberti, em cujo tratado ela representa apenas o contorno do desenho, não incluindo o preenchimento de claros-escuros. ALBERTI, Leon Battista, op. cit., p. 82: "Però che la circonscriptione è non altro che disegniamento del orlo quale, ove sia
} 
implica no acomodar o ser vivo a uma boa luz, colocá-lo em uma bela posição; possuir boa maneira no desenhar; ter conhecimento de invenções quanto aos suportes e técnicas pictóricas, como aprender a pintar em cartas-tintas, com pedra negra, biaca, aguada; ter conhecimento do traço a pena. ${ }^{117} \mathrm{E}$ a última parte pertencente ao desenho dita reta composição inclui todas as outras, juízo, circunscrição e prática. Consiste no formar integralmente as superfícies, dar justa proporção ao todo, imitar bem a propriedade dos elementos representados, contrafazer bem os escorços. ${ }^{118}$

À segunda parte da própria partição da pintura é intitulada por Pino invenção, tendo sido já mencionada acima. E por último o colorir que representa uma composição de cores feitas nas superfícies descobertas à vista. O colorir é composto de três momentos. Primeiro, no discernir as propriedades das cores, compreendendo bem suas composições e reconduzindo-as à semelhança da propriedade dos elementos. ${ }^{119}$ Segundo, na prestreza e segurança da mão ao pintar. ${ }^{\mathbf{1 2 0}}$ Terceiro e último, o lume, alma do colorir. ${ }^{121}$

Se o tratado de Pino em particular teve como paradigma o Da Pintura, de Alberti, assemelhando-se ele quanto à estrutura literária oriunda dos antigos tratados isagógicos,

fatto con linea troppo apparente, non dimostrerà ivi essere margine di superficie ma fessura et io desidererei nulla proseguirsi circonscrivendo che solo l'andare del orlo". Cf. Anexo, p. 46.

${ }^{117}$ Idem, ibidem, pp. 15-16: "La tertia è la pratica del saper accomodare il vivo à buon lume, conoscere il bello, perché molte cose propie sono belle in sé, che fatte in pittura paiono isgratiate e goffe; haver buona maniera nel disegnare, saper l'inventioni, come in carte tinte, con lápis nero e biaca, toccar d'acquaticie, trattegiar di penna, ma lo chiaro e scuro è il più presto e più útil modo, e il migliore, perché si puó bene unire il tutto, e dar più mezze tinte e più chiare". Cf. Anexo, p. 46-47.

${ }^{118}$ Idem, ibidem, p. 16: "L'ultima poi è detta compositione, in questa s'include tutte l'altre, cioè, il giudicio, la circoscrittione e la pratica. Impero ché questa retta compositione consiste nel formar integralmente le superfitie, le quali sono parti de membri e i membri, come parte del corpo poi, come integrità dell'opera, questa dà la giusta portione al tutto, imita ben il propio, come un vecchio, un giovane, un fanciullo, uma femina, un cavallo e l'altre diverse specie, si ah'uno non assomiglia all'altro, contrafà ben gli scurci, parte più nobile nell'arte nostra, figne ben li drappi senza confusione di pieghe, sempre accenando il nudo sotto da gran rilevo al tutto, e questo è lo spirito della pittura". Cf. Anexo, p. 47-48.

${ }^{119}$ Idem, ibidem, p. 17: "La tertia e ultima parte della pittura è il colorire, questa è una compositione de colori nelle parti scoperte al vedere, perché a noi non appartengono quelle cose che non si scopreno al veder, stando in un temine, essendo la pittura próprio soggetto visivo. Il colorire consiste in ter parti, e prima, nel discernere la proprietà delli colori, e intender ben le compositioni loro, cioè, redurli alla similitudine delle cose propie [...]".Cf. Anexo, p. 53.

${ }^{120}$ Idem, ibidem, p. 18: "La prontezza e sicurità di mano è gratia concessa dalla natura [...]". "Tornando ao ragionamento, dico che la prontezza di mano è cosa de grande importanza nelle figure, e mal può operare um pittore senza una sicura e stabil mano, e quello assicurarsi sopra la bacchetta non fu mai usato dagli antichi, anzi è cosa vituperosa, dica chi vuole". Cf. Anexo, p. 54.

${ }^{121}$ Idem, ibidem: "Del lume, ultima parte e anima del colorire, dicovi, ch'all imitatione del próprio vi conviene haver buon lume, che nasci da una finestra alta e non vi sia refletto de sole, o altra luce. Questo perché le cose, che ritraggete si scuoprano meglio e con più gratiato modo, e ancho le pitture hanno più de forza e rilevo, e in ciò loderei ch'il pittore elegesse il lume nell'Oriente, per esser l'aria più temperata e gli venti di quello meno cattivi”. Cf. Anexo, p. 55-56. 
Creighton Gilbert propõe em uma mesma instância que o Dialogo di Pittura apresenta importantes pontos de contraste em relação ao tratado do florentino ${ }^{\mathbf{1 2 2}}$ que se revelam justamente na argumentação sobre as partes da pintura.

Conforme Gilbert, das quatro partes do desenho, juízo que ao ser proposto enquanto talento inato do pintor é na verdade uma faculdade própria à sua personalidade, e não aos procedimentos operacionais da pintura. Todavia Pino estabelece um vínculo forçado com o desenho, submetendo-o a ele. A composição, por outro lado, que deveria ser o todo da obra com a inclusão do desenho (e não sendo subjugada a ele), junto a claros-escuros, cores, elementos perspécticos, é definida no discurso de Pino como a soma e combinação das outras três partes. Desse modo, ela acaba por se confundir com o desenho, vindo a ser um todo obscuro, com características quase idênticas a ele. ${ }^{\mathbf{1 2 3}}$

As partes do colorir, enquanto cada uma delas válidas, todas pertencem a diferentes sistemas de avaliação: proprietà apresenta-se como critério iconográfico; prontezza enquanto aspecto do caráter pessoal do pintor e lume, um componente formal. Conforme Gilbert, há uma falta de coerência entre sua inter-relação e combinação para compor e definir o que Pino denomina de "colorir". Estas partes formam um conjunto não coeso, que foi estabelecido de modo muito mais verbal do que propriamente sistemático da operação da pintura. ${ }^{124}$

Contudo, se à primeira vista este esquema mostrou-se ser um tanto quanto inconsistente, na verdade tinha de ser estabelecido dessa forma, para se adequar ao cotejo e classificação da Arte Retórica, para cujas partes, inventio, dispositio, elocutio, memoria, pronuntiatio, Pino prescreveu elementos equivalentes que dissessem respeito à arte da pintura, prescrevendo uma proximidade entre as duas artes. ${ }^{\mathbf{1 2 5}}$

${ }^{122}$ GILBERT, Creighton, op. cit., p. 94.

${ }^{123}$ Idem, ibidem, p. 94-95: "[...] Thus, among the four parts of disegno, giudizio is explained as original native talent, which hardly comes under the usual meaning of disegno. Composizione, on the other hand, is defined only as the sum and combination of the other three, wich would seem to make its relation with disegno as a whole obscure, if not to make them identical".

${ }^{124}$ Idem, ibidem, p. 95: "The parts of colorire, while each valid, all belong to different systems of evaluation, proprietà, being an iconographical standard, prontezza, an aspect of the painter's personal character, and lume, a formal constituent. Their interrelationship and their combination to make up colorire is clearly more verbal than systematic. All these values were felt necessary for various reasons, but as a system they are merely garbled. Hence this set of terms is not so inconsistent with Pino's general discursive tone as might at first glance be supposed".

${ }^{125}$ Idem, ibidem: "There is however, a simple explanation for the framework: it had to be fitted to a preexisting scheme. The conventional antique classification of the art of rhetoric is as follows: inventio, 
Gilbert salienta igualmente que um paralelo poderia ser feito entre elocutio e colorire se fosse possível considerá-los enquanto elementos de ornamentação, uma vez que toda a estrutura poderia ser eficaz mesmo com a ausência de ambos. Na Idade Média, entre as disciplinas do Trivium, à Gramática cabia o papel da eloqüência, à Dialética o doutrinar e à Retórica, o colorido das palavras. ${ }^{\mathbf{1 2 6}}$ Se a expressão "cores da retórica" na teoria medieval abrangia e monopolizava a disciplina como um todo, sendo considerada como a seção mais importante da elocutio, segundo Gilbert a transposição efetuada por Pino equivale-se a ela, ou seja, sua proposição relativa ao colorido equipara-se à elocutio. ${ }^{\mathbf{1 2 7}}$

Dispositio e disegno também apresentam função paralela, uma vez que são elementos estruturais em ambas as artes, assim como uma semelhança com o discurso pelo fato de que o elemento mais importante do desenho seja a composição. A identidade entre os dois se faz porque cada um está organizado em quatro partes. Juízo, circunscrição, prática e composição no desenho, correspondem respectivamente ao exordium, a narratio, a confirmatio e a peroratio, da dispositio. Esta subdivisão foi utilizada por Cícero e posteriormente pelos teóricos da Idade Média, com algumas distorções, mas que serviu de modo considerável aos seus propósitos. No entanto, no tratado de Pino, de acordo com Gilbert esta re-utilização da antiga estrutura resultou de modo não conveniente, constituindo-se apenas como uma correspondência numérica. ${ }^{\mathbf{1 2 8}}$

Estas subdivisões retóricas, segundo Gilbert, foram utilizadas por Alberti como uma seqüência orgânica e coerente daquela estrutura clássica. Por sua vez, a correspondência

dispositio, elocutio, memoria, and pronuntiatio. The last two, however, are "really not permanent parts of rhetoric, but only of the rhetoric os spoken address". In medieval rhetoric they disappeared for the most part. Thus the numerical equation with Pino can be posited without unduly forcing the issue".

${ }^{126}$ Cf. GILBERT, C., op. cit., p. 102, nota 29: "[...] Nicolaus de Orbellis supplied these definitions of the trivium: "Grammatica loquitur; Dialectica vera docet; Rhetorica verba colorat", citado por CLARK, D.L. Rhetoric and Poetry in the Renaissance, New York, 1922, p. 56.

${ }^{127}$ Idem, ibidem: "A satisfactory parallel between elocutio and colorire might be drawn by considering each as an embellishment for a product structurally complete without it. But a verbal analogy can be made much more directly. The familiar "colors of rhetoric" which in medieval theory engulfed and monopolized the whole discipline, are strictly regarded as a section of elocutio, and as its most important part; hence, in the medieval transformation traditional to Pino, as its equivalent".

${ }^{128}$ Idem, ibidem, p. 95-96: "Dispositio and disegno likewise have a general parallel function as the structural elements in the two arts, and general verbal likeness in that the most important element of disegno is composizione. The clinching identity between them, however, because the most exact and literal, is that each of them is organized in four parts. [...] The four rhetorical subdivisions (exordium, narratio, confirmatio, peroratio) are those used by Cicero and traditionally in the Middle Ages, though their contortions for re-use at that time are often as remarkable and as awkward as in Pino". 
realizada por Pino parece carecer de autenticidade onde os elementos de ambas as artes não se entrelaçam de modo tão intrínseco quanto ele o pretendera, ou seja, demonstrar que essa ligação sempre existiu e fora real, quando na verdade ela não deixa de ser a sua construção discursiva, onde cada um de seus argumentos serve muito mais a "persuadir" o leitor, do que comprovar a sua tese.

Se na leitura da Antiguidade por Alberti, ele se amparou em uma estrutura por sistemas, Pino traduziu o antigo por meio de um discurso retórico. E se Alberti associa a pintura à matemática, Pino a interliga muito mais à poesia. Antes de Pino e Alberti o esquema retórico inventio-dispositio-colores foi utilizado por Pomponio Gauricus em seu De Sculptura (1504) e por Francesco Lancilotti, em seu Tractato di Pictura (1509).

A divisão que Dolce prescreve para a pintura é a mesma realizada por Pino: invenção, desenho e colorido. ${ }^{129}$ Invenção, fábula ou história a ser narrada pelo pintor, já tratada em parágrafos anteriores. Desenho, sendo a forma com que o pintor representa a história. ${ }^{130} \mathrm{E}$ o colorido, as tintas com as quais a natureza pinta diferentemente as coisas animadas ou inanimadas. ${ }^{\mathbf{1 3 1}}$

Segundo R. W. Lee, o significado de invenção no tratado de Dolce equipara-se à inventio, que em Cícero e Quintiliano teria representado a definição da matéria a ser tratada no discurso do orador. Para Dolce, a invenção incluiria ainda o plano geral da composição. Desenho iguala-se à dispositio, que para os retóricos tinha o sentido de esboço ou delineamento preliminar do discurso, assim como a clara indicação do resumo estrutural de sua forma final numa relação das partes com o todo. O colorido, a execução final da pintura, por sua vez, indicaria a elocutio, a expressão final de toda a linguagem do discurso. $^{132}$

Estabelecendo um cotejo entre Dolce e Alberti, com relação às partes da pintura, Lee observou ainda existir uma analogia entre a circunscrição, composição, e recepção de lumes, feitas pelo florentino e a subdivisão do veneziano. ${ }^{133}$ Assim, se para Alberti a circunscrição representava o desenho de figuras em esquema (esboço); a composição sendo

\footnotetext{
${ }^{129}$ DOLCE, Lodovico, op. cit., pg. 164: "Tutta la somma della pittura, a mio giudicio, è divisa in tre parti: invenzione, disegno e colorito". Cf. Anexo, p. 111.

${ }^{130}$ Idem, ibidem: "Il disegno è la forma con che egli la rappresenta (l'istoria)". Cf. Anexo, p. 111.

${ }^{131}$ Idem, ibidem: "Il colorito serve a quelle tinte, com le quali la natura dipinge (che così si può dire) diversamente le cose animate et inanimate [...]".Cf. Anexo, p. 111.

${ }^{132}$ LEE, R. W., op. cit., p. 264-265.

${ }^{133}$ Idem, ibidem.
} 
a indicação de planos dentro do esquema e recepção de lumes e a execução do colorido, as relações entre luz e cor, Lee expõe que a composição de Alberti corresponde em parte à invenção de Dolce. Porque ela inclui também a indicação de planos em luz e sombra que a distingue em um puro sentido técnico da circunscrição, o plano da composição e matéria de decoro e expressão.

Segundo Alberti, a invenção deveria estar parcialmente incluída na composição (quando ele discorre sobre o arranjo e decoro em seu tratado), sendo mencionada no fim de seu livro em conexão aos seus conselhos concernentes ao conhecimento literário.

Dispositio, o esquema preliminar do discurso do orador, seria representado pela composição, a qual incluiria a indicação de como as partes dos elementos naturais percebidas pelo pintor são representadas na pintura. Por circunscrição, compreende-se o esquema de desenho através do qual a disposição das figuras em um esboço deveria ser precisamente feita. E na elocutio a verdadeira execução do discurso deveria ser representada na pintura pela recepção de lumes, à completa realização do quadro. Dolce retoma assim não somente Alberti como Daniello, o qual em seu tratado expõe a tripartição da poesia em invenção, disposição e elocução. ${ }^{134}$

Finalizando, neste capítulo intentamos demonstrar a adesão de Paolo Pino e Lodovico Dolce como teóricos pertencentes ao grupo de idealizadores da doutrina do $u t$ pictura poesis, por sua enfática argumentação da intrínseca relação entre pintura, poesia e Arte Retórica. Tentamos também demonstrar a trama de enlace dos tratadistas e suas fontes, afirmando que, em detrimento aos teóricos da região Tosco-Romana (que tinham Platão como mentor filosófico), eles se basearam principalmente nas Artes Poéticas, sejam de Aristóteles, de Horácio, ou a de Bernardino Daniello, tanto quanto em obras de retores como Marco Túlio Cícero e Quintiliano.

$* * *$

\footnotetext{
134 DANIELLO, op. cit. p. 411, nota 11: “Adunque dalla prima di queste tre parti [della poesia: cioè invenzione, disposizione ed elocuzione] incominciando, dico niuna materia esser, com'alcun crede, ad esso poeta determinata; anzi essergli conceduto ampia licenza - sì come ancora à al dipintore, di finger molte e diverse cose diversamente - di potere di tutte quelle cose che in grado li siano, ragionare et iscrivere". Sobre a licença de criação de poetas e pintores, Daniello retoma Horácio.
} 


\section{Capítulo IV}

\section{$O$ ideal de beleza nos Tratados}

A reflexão e investigação sobre o conceito de beleza a partir de suas relações físicas e metafísicas ocorreu em paralelo ao percurso da história do pensamento ocidental. De Platão e Aristóteles aos teólogos da Idade Média, como Santo Agostinho e São Tomás de Aquino, aos humanistas do Renascimento, como Marsilio Ficino e Agostino Nifo, todos a seu modo emitiram uma consideração a respeito do tema.

Em se tratando das belas artes e sendo a figura humana objeto principal de representação, seja da pintura, seja da escultura, desde a Antiguidade Clássica até o momento em que outros motivos ganharam relevância no centro da composição, o que deu margem ao surgimento de novos gêneros pictóricos entre o final do século XVI e meados do século XVII, a busca por um paradigma de beleza ideal (intrinsecamente ligado ao processo de imitação da natureza) tornou-se matéria constante da literatura artística, na medida em que as investigações de ordem prática e científica, em grande parte solucionadas pelos artífices do século XV, foram substituídas pela evolução de uma teoria artística propriamente dita.

Nos tratados de Pino e Dolce a discussão da temática alcança significação quando do embate entre beleza natural e beleza artística, sofrendo em cada um dos escritos um desdobramento distinto. Após ambos definirem o conceito de beleza em seus tratados, Pino volta-se para a concepção de um paradigma de beleza feminina ideal, enquanto Dolce atémse à beleza da figura humana em sua totalidade de características, devendo ser derivada do modelo clássico da estatuária greco-romana. Esta premissa coloca no centro de sua argumentação a defesa da representação figurativa de Rafael Sanzio em contraposição à de Michelangelo Buonarroti.

A retomada da tradição clássica com a descoberta, tradução e comentário de textos antigos, em particular aristotélicos e platônicos, que a princípio circulavam em forma de manuscritos e posteriormente passaram a sucessivas impressões entre a segunda metade do século XV e ao longo do XVI, impulsionou os estudos científicos e filosóficos do período, que permaneciam em debate numa esfera mais circunscrita aos humanistas eruditos. 
Concomitante a este círculo de sapiência havia a cultura da vida civil, onde homens e mulheres não menos doutos apreciavam conversas informais sobre os mais variados assuntos, como comprovam os tratados de civilidade da época que foram escritos em forma dialógica, tais como $O$ Cortesão e $O$ Galateo. Temas como beleza, amor, honra, duelo, nobreza, riquezas e letras faziam parte de um vasto campo de discussões entre os nobres, oportunidade na qual letrados mais virtuosos podiam dar mostra de seus conhecimentos estilísticos. $^{135}$

A despeito de numa primeira instância a beleza não ser preocupação dos artífices no tocante às pesquisas para a composição de suas obras, uma vez que no século XV eles estavam ainda envolvidos em reivindicar a legitimação de sua arte e seu ofício, a matéria foi ganhando espaço no meio artístico, dado que as idéias circulavam no ambiente cultural das cortes, onde nobres, eclesiásticos, humanistas e artífices freqüentavam-se mutuamente.

Salientamos que entre o final do XV e primeira metade do XVI a conquista do artífice pela dignidade de homem culto consolida-se igualmente nesse período, quando o estatuto de sua profissão adquire de modo gradual reconhecimento e distinção. Por conseqüência, ele torna-se cortesão e passa a freqüentar a corte e o convívio de humanistas e poetas. ${ }^{136}$ Essa circunstância enriqueceu as polêmicas e o intercâmbio de idéias entre as diversas áreas, fossem elas artes figurativas, belas letras, poesia e filosofia. E o artífice transformou-se em loquaz interlocutor junto aos letrados com respeito às próprias teorias de seu ofício e aos temas que lhe eram caros.

No âmbito da filosofia o conceito do belo nas contendas realizadas pelos humanistas ocasionou influxos tanto nos escritos artísticos quanto nos tratados de amor, e decorreu do reflexo exercido pelos estudos de Platão feito por Marsílio Ficino no século XV, através dos quais questões como beleza, bem e amor foram retomadas e comentadas a partir de

\footnotetext{
${ }^{135}$ GARIN, Eugenio. L'Umanesimo Italiano - Filosofia e vita civile nel Rinascimento. Roma-Bari, Giuseppe Laterza \& Figli, 1984, p. 133: "Se apriamo i Discorsi divisi in sette giornate (1586), del conte Annibale Romei, gentiluomo ferrarese, nei quali sono introdotti a dissertar di filosofia, per sette giornate, "dame e cavaglieri", alla presenza di Francesco Patrizi, vediamo che gli argomenti trattati sono la bellezza, l'amore, l'onore, il duello, la nobiltà, le ricchezze, le lettere. L'opera del Romei è lo specchio fedele di quelli che furono gli effetivi temi del comune dissertare cinquecentesco non "scolastico", ove in discussioni di maniera venne estenuandosi l'oposizione platonica all'aristotelismo accademico".

${ }^{136}$ Como já referido, observamos que Alberti e Leonardo, já na segunda metade do século XV, também freqüentavam a corte e o convívio de religiosos e nobres, mas no século XVI esta conquista tornou-se regra entre os maiores artífices.
} 
argumentos constantes no Hípias Maior, Banquete e Fedro. Palestras sobre estes temas foram ministradas por humanistas na Academia Platônica fundada por Ficino, repercutindo posteriormente nos círculos doutos onde polemizavam letrados, artistas e poetas sobre os assuntos em voga. Com o trânsito desses humanistas entre as várias cortes italianas, tais argumentações difundiram-se para as outras regiões da Península.

A temática da beleza esteve presente desde os primeiros tratados artísticos a promover a argumentação sobre uma teoria da arte como o Da Pintura, de Alberti, e o Tratatto della Pittura, de Leonardo, aos escritos que os sucederam no século XVI e adiante. Nessa linha de continuidade, Pino e Dolce enfocam suas premissas no embate entre beleza natural versus beleza artística dialogando de modo velado com algumas noções dos pensamentos aristotélico e platônico.

No campo da filosofia, este embate e seu correlato pressuposto da concepção de um ideal de beleza está imediatamente mergulhado no cerne da teoria do conhecimento de Platão, em sua complexa Doutrina das Idéias, através do qual se desenrolam as problemáticas sobre a dicotomia entre o mundo sensível dos corpos e o mundo das formas puras, resultando a partir destes dois enfoques profundas conseqüências para a teoria da arte e cuja repercussão maior será o repúdio de Platão às artes denominadas miméticas.

No Renascimento a reprodução fiel da natureza estava diretamente vinculada à formulação da beleza. E apesar do raciocínio sobre esta temática ser exposto por Pino e Dolce, havendo inclusive menção por parte deles do termo Idea, segundo Erwin Panofsky, uma teoria das Idéias não havia ainda ganho plena significação na discussão do teóricos do período, tomando lugar somente a partir do final do século XVI. ${ }^{137}$ A contenda que se insurge no círculo erudito leva a dois caminhos de investigação: se a concepção de uma beleza ideal da figura humana decorre de uma relação puramente mimética com o mundo natural veiculado pela prática e experiência do artífice, ou se o modelo tem origem a partir de uma idéia mental pré-concebida, independente de um estudo da natureza.

Em importante ensaio sobre os problemas do belo e da arte nos diálogos de Platão, Ernst Cassirer discorreu sobre a procedência dos termos Idea e Ideal a partir de dois conceitos oriundos da filosofia platônica, os quais, a despeito de incidir em sua rejeição às

\footnotetext{
${ }^{137}$ PANOFSKY, Erwin, op. cit., p. 74.
} 
artes miméticas, trouxe conseqüências significativas para a teoria artística, em particular no período do Renascimento.

Segundo Cassirer, na concepção e fundamentação originárias da Doutrina das Idéias jamais existiu espaço algum para o desenvolvimento de uma ciência da arte. No pensamento de Platão a arte concerne unicamente à aparência sensível das coisas e tal motivo a torna incapaz de nos fornecer um saber rigoroso do mundo dos fenômenos; ao contrário, ela nos transmite apenas um conhecimento cuja base assenta-se na opinião e na imaginação. ${ }^{138}$ Porém, esta colocação revela um paradoxo se levarmos em conta que a Doutrina das Idéias e as questões suscitadas por ela, bem como sua condição histórica, gerou efeitos tão fortes e amplos para a teoria da arte como nenhum outro sistema filosófico o fez, e ainda assim Platão negou ao campo da arte uma existência própria, uma autonomia e direitos que ele, no entanto, concedeu a outros saberes. ${ }^{139}$ A todo momento, no percurso dos séculos em que uma teoria da arte e do belo tomou forma, a abordagem adotada sempre se voltou para o conceito de Idea platônica ao qual estava intrinsecamente vinculado a noção de Ideal. ${ }^{\mathbf{1 4 0}}$ E tanto filósofos (como Plotino, Santo Agostinho, Marsilio Ficino, Winckelmann, Schelling), poetas e artistas (entre eles, Göethe e Michelangelo) testemunharam o quanto esta conexão com a tradição platônica manteve-se sempre viva ao longo dos séculos, justamente por serem estes conceitos elementos centrais na reflexão do processo conceptivo das artes poéticas e figurativas. ${ }^{141}$

${ }^{138}$ CASSIRER, Ernst - Eidos et Eidolon. Le Problème Du Beau et de l'art dans les Dialogues de Platon in Écrits sur l'Art, traduit de l'allemand par Christian Berber - Oeuvres de Cassirer (XII) éditées en français, en collaboration avec la Internationale Ernst Cassirer-Gesellschaft sous la direction de Fabien Capeillères et Heinz Wismann - Yale University Press, New Haven, Connecticut et Les Éditions du Cerf, Paris, 1995, p. 29: "La théorie platonicienne des Idées n'accorde, dans sa conception et fondation originelles, aucune place à une esthétique autonome, à une science de l'art. Car l'art reste rivé à l'apparition sensible des choses dont il ne peut jamais y avoir rigoureux, mais toujours qu'opinion ou imagination".

${ }^{139}$ Idem, ibidem: "Si cette décision, mesurée à l'ensemble de la personnalité de Platon, semble paradoxale, ce paradoxe se trouve amplifié dès que l'on considère la théorie des idées dans sa structure purement objective et dans son destin historique objectif. Car aucune théorie philosophique n'a été le point de départ d'effects esthétiques plus étendus et plus forts que ce système que refuse à l'esthétique une existence propre et indépendante, jouissant des mêmes droits".

${ }^{140}$ Idem, ibidem: "Où que l'on ait, au cours des siècles, recherché une théorie de l'art e du beau - le regard revenait toujours, comme par contrainte intellectuelle, au concept et au terme d' "Idée", auquel alors, comme une pousse nouvelle, venait se joindre le concept d'idéal".

${ }^{141}$ Idem, ibidem: "Et non seulement les théoriciens de l'art, mais les grands artistes eux-mêmes sont les témoins de cette connexion restée vivante à travers les siècles. À la série qui conduit de Plotin à Augustin, d'Augustin à Marsile Ficin, de celui-ci à Winckelmann et à Schelling, correspond la série des grands artistes qui, chacun dans as propre voie et cependant comme sous le charme d'une tradition continue, a cherché et trouvé son chemin vers Platon. Il suffit de nommer Michel-Ange et Goethe pour prendre conscience de la force et de la diversitè de cette connexion relevant de l'histoire de la pensée". 
Ambos os termos, Idea e Ideal encontram suas raízes em dois conceitos fundamentais na filosofia de Platão, eidos e eidolon, forma e imagem, os quais, de acordo com Cassirer, abrangem toda a extensão do mundo platônico, representando os dois pontos focais para os quais seu pensamento sempre retorna, sendo ao mesmo tempo seus limites extremos. ${ }^{142}$ Eidos e eidolon procedem de uma mesma raiz lingüística, desdobram-se a partir de um idêntico significado fundamental do sentido da visão e, todavia, pelo específico sentido atribuído a eles por Platão, encerram em si duas diferentes direções do "ver", duas qualidades contrárias da visão. No primeiro caso, "ver" traz o caráter passivo da percepção sensorial que procura registrar e reproduzir em si um objeto externo sensível, o eidos. No outro, "ver" torna-se livre contemplação em vista da apreensão de uma forma objetiva, a qual todavia não pode ser realizada senão como ato intelectual de configuração, o eidolon. ${ }^{143}$ Resulta do contraste entre estes dois conceitos a crítica que Platão teceu sobre a arte, pois o artista absorve as formas sensíveis (eidon-Idea) que seu olhar capta do mundo natural, para delas derivar uma imagem mental ideal (eidolon-Ideal) da qual se utiliza para representar em sua obra. Platão, contudo, não legitima este processo do artista enquanto criação ou busca de conhecimento, pois, para ele, a obra do artista não desvenda o mundo sensível, apenas mimetiza-o, enfatizando sua transitoriedade e inconstância; é, a seu ver, apenas uma aparência ou sombra do verdadeiro mundo das Idéias.

Na cosmologia de Platão, uma nítida cisão separa o mundo aparente dos corpos do conteúdo e verdade do que ele denomina de formas puras, ou conceitos matemáticos. Seu sistema filosófico considera ser impossível alcançar o lado verídico, a origem ou autêntico "princípio" do mundo fenomênico, analisando-o unicamente por meio de suas determinações sensíveis. ${ }^{144}$ Platão não concebe o mundo natural como um mero conjunto

\footnotetext{
${ }^{142}$ Idem, ibidem p. 30: "Chez Platon lui-même, le conflit des motifs qui s'enclenche ici peut être marqué le plus clairement à partir de l'opposition entre deux concepts ayant pour lui une importance strictement fondamentale et constituant en quelque sorte les deux foyers autour desquels sa pensée tourne constantement. Eidos et eiddon, figure et image - cette paire de concepts embrasse pour ainsi dire toute l'étendue du monde platonicien et represente sés deux limites extremes".

${ }^{143}$ Idem, ibidem, p. 30-31: "Eidos et eiddon, deux termes qui procèdent de la même racine linguistique, qui tous deux se développent à partir d'une signification fondamentale du voir, - et qui cependant renferment selon Platon, dans le sens spécifique qu'il leur donne, deux "qualités" opposées de la vision. Dans un cas, voir porte le caractère passif de la sensation sensible qui ne cherche qu'à recueillir en soi et à reproduire un objet sensible extérieur - dans l'autre, il devient libre contemplation en vue de la saisie d'une figure objective, mais qui ne peut elle-même être accomplie autrement que comme acte intellectuel de configuration".

${ }_{144}$ Idem, ibidem: "Une coupure nette sépare [...] l'existence simple des apparitions et la teneur et vérité des formes pures. Il est impossible d'accéder à l'origine propre et authentique, au "principe" du monde sensible,
} 
de forças e coisas materiais, mas devido à ordem eterna que o domina, em sua opinião, ele toma parte no reino da forma pura dos conceitos matemáticos. ${ }^{145} \mathrm{O}$ mundo sensível dos corpos e das sensações não nos mostra constância nem uniformidade de um conteúdo em si mesmo, pelo contrário, representa o âmbito da contradição, não conhece determinações estáveis, pois é o reino de uma série ininterrupta de delimitações que reciprocamente se eliminam. ${ }^{146}$ E nelas não existe, portanto, propriedade autônoma por si existentes que se poderiam como tais fixar univocamente e estabelecer com o pensamento, pois toda vez que acreditamos ter colhido qualquer coisa, ela se dissolve num mero vir-a-ser ou um conjunto de meras relações. ${ }^{147}$ Frente a este ondular da percepção e da representação sensível, o pensamento não pode fazer outra coisa senão retirar-se em direção à determinação da própria essência. ${ }^{148}$ Assim, para Platão, o único caminho de se obter o conhecimento verídico de um mundo cuja aparência encontra-se em constante oscilação e movimento, é estabelecer uma conexão entre suas características essenciais e os conceitos matemáticos.

Esta conexão, ou uma ciência da natureza, Platão a idealizou nos livros centrais da República, mas não com a intenção de colhê-la em sua plenitude sensível e de multiplicidade, porém, como teoria pura da natureza na qual realizava uma aplicação da teoria matemática ao transformar seus elementos em problemas matemáticos considerandoos desse modo sob nova perspectiva. ${ }^{149} \mathrm{O}$ esforço de querer encontrar os elementos essenciais da natureza no próprio mundo físico é rejeitado desde o início. O universo não é

tant que nous cherchons encore en lui-même ce principe ou tant que nous le pensons encore affublé d'une manière ou d'une autre de déterminations sensibles".

${ }^{145}$ Idem, ibidem, p. 31-32: "Car la nature n'est pas elle non plus un simple concept générique de choses et de forces matérielles, mais elle participe, au moyen de l'ordre éternel qui règne en elle, au royaume de la forme pure".

${ }^{146}$ Idem, ibidem, p. 33: "Nulle part le monde sensible, le monde de la sensation et de la perception immédiate, ne nous montre cette constance, cette uniformitè d'un contenu avec lui-même. L'une de ses caractéristiques fondamentales est bien plutôt qu'à peine posé, tout contenu s'anéantit en lui. Il est le domaine de la contradiction - il ne connaît pas tant des déterminités fixes qu'il n'est une série continue de déterminations qui alternativement se suppriment les unes les autres".

${ }^{147}$ Idem, ibidem: "Aussi n’y a-t-il pás en lui des "propriétés" indépendantes, existant pour elles-mêmes, qui pourraient être fixées et saisies intellectuellement de manière univoque - mais partout où nous crovons avoir saisi quelque chose constitué d'une certaine manière, [...] il se dissout immédiatement en simple devenir ou même en un ensemble de simples relations".

${ }^{148}$ Idem, ibidem: "Au regard de ce flottement et de cette oscillation de la perception sensible et de la représentation, la pensée est condamnée à se retirer dans la déterminité de sa propre essence".

${ }^{149}$ Idem, ibidem, p. 37: "Ce qui est ici exigé est réalisé dans les livres centraux de La Republique par la place qu'y prend la science de la nature. La science de la nature n'existe pas pour elle-même avec pour intention de saisir et d'épuiser sa plénitude et variété sensible concrète; en revanche, il existe bien une théorie pure de la nature, qui est un cas particulier et une application spéciale de la théorie mathématique - qui transforme les choses de la nature en problèmes de la mathématique et les place ainsi dans une tout autre perspective". 
uma mera mistura de matérias, mas em seu sistema é conformado em si mesmo e de acordo com figuras e números. ${ }^{150}$

A premissa de Platão, se considerada no âmbito da arte, acarreta de modo direto o profundo contraste entre o eidos e o eidolon, ao expor o cerne da diferença entre ambos os conceitos. Ao vincular os elementos do mundo sensível dos corpos aos conceitos matemáticos, Platão estabelece uma norma que possibilite obter deste mundo dos fenômenos um conhecimento objetivo, determinado, estável, o qual só pode ser realizado quando conectado à essência das figuras e números. Se o eidos, ou formas sensíveis, tornam-se análogas às formas puras objetivas apreendidas do mundo sensível, o eidolon, em contrapartida torna-se imagem/aparência destas formas não podendo revelá-las segundo a objetividade que lhes propõe Platão, mas conforme a subjetividade interior daqueles que as vê.

A arte, ao lidar de modo imediato com o conceito do eidolon entra em choque com esta premissa platônica de delimitar a essência objetiva do mundo sensível, porque ao mimetizá-lo ela nos oferece, de acordo com Platão, apenas uma aparência deste mundo demonstrando a pretensão de criar uma "segunda natureza". ${ }^{151}$ Pois que o artista, no momento em que toma os movimentos da mera imitação, não procura a medida objetiva das coisas, porém, a representa em seu pleno cambiar e mudar, em toda a casualidade de sua aparência exterior. ${ }^{152}$ Ele não as revela como são determinadas em si próprias, mas assim como se apresentam ao observador favoravelmente à posição e condição deste último, e ainda, favoravelmente a outros condicionamentos externos, tais como sujeitas à iluminação cambiante. ${ }^{153} \mathrm{O}$ artista não suprime todos estes aspectos subjetivos, pelo contrário, ele os procura e os evidencia intencionalmente. Ao invés da realidade da forma,

\footnotetext{
${ }^{150}$ Idem, ibidem: "Ici aussi l'effort pour trouver les éléments essentiels de la physis dans la physique ellemême est d'entrée de ieu rejeté [...]. L'univers n'est pas un simple mélange de matières, il est en lui-même configuré - configuré conformément à des figures et des nombres".

${ }^{151}$ Idem, ibidem, p. 39: "Mais une fois encore le conflit entre le monde des formes pures et le monde des simples images, le conflit entre eidos e eidolon se dresse devant nous dans toute sa netteté lorsque nous l'envisageons non plus dans le domaine de la nature, mais dans celui de l'art. Car l'art a la prétension de nous présenter une "seconde nature".

${ }^{152}$ Idem, ibidem, p. 44: "Car l'artiste, dans la mesure où il ne recherche que la simple imitation, n'interroge pas les mesures objectives des choses, mais les présente suivant l'échange et le changement, suivant toute la contingence de leur apparition externe".

${ }^{153}$ Idem, ibidem: "Il ne les rend pas suivant leurs déterminations internes, mais comme elles se présentent à celui qui contemple, relativement à sa position, à sa situation et à d'autres circonstances extérieures, par exemple à l'éclairage changeant".
} 
ele põe assim diante de nós a sua imagem aparente, afetada por toda sorte de modificação, abreviação e distorção. ${ }^{154} \mathrm{O}$ reino do artista é da ilusão, do entrelaçamento e de um recíproco compenetrar-se entre aparência e realidade efetiva. ${ }^{155}$ Nesse sentido, para Platão o artista assemelha-se ao sofista, pois o ofício de ambos ancora-se na subjetividade, e ambos se valem como que de um encantamento mágico para persuadir e convencer as pessoas. Dessa maneira, a arte do poeta, do pintor e do escultor, tanto quanto àquela do sofista, são equiparadas no pensamento de Platão à arte do mago. ${ }^{156}$

Em se tratando de uma concepção de beleza, objetivo a que se propõe todo artista e em consonância ao acima exposto, é preciso afirmar que, segundo Platão, tudo o que é belo, qualquer que seja sua natureza singular, no tocante ao belo natural ou ao belo artístico, deverá repousar, em última análise, sobre puras determinações numéricas e de medida, dado que é inadmissível para ele que alguma forma sensível possa se igualar em beleza às formas puras da matemática, em particular dos corpos regulares da estereometria. ${ }^{157}$

Em seu diálogo Filebo, Platão reconhece de modo expresso um "prazer puro" (puro, em seu sistema, abrange um significado que remonta à esfera religiosa), resultante da consonância, harmonia e proporção das formas e de uma natureza absolutamente particular e em nada comparável à sensação do prazer sensível. A autêntica beleza significa para Platão, para além da percepção dos números, a beleza dos corpos vivos ou de certos quadros, porém, a beleza das superfícies e de corpos determinados pelo metro e pelo grau. $^{158}$

${ }^{154}$ Idem, ibidem: "Il n'efface pas tous ces moments subjectifs, mais les recherche et les fait ressortir intentionnellement. Ainsi, au lieu de l'effectivité de la figure, il ne nous presente que son image apparente, entachéé de toutes sortes de déplacements, de raccourcis et de déformations. Le miméticien cherche par là à nous attacher à cette immédiateté en la présentant précisément comme ce qui est authentique et ultime, comme ce qui est purement et simplement l' 'étant', au lieu de nous libérer de l'immédiateté sensible de l'impression".

${ }^{155}$ Idem, ibidem, p. 45: "Son royame est le royame de l'illusion, celui du mélange, de la confusion de l'apparence et de la réalité effective".

${ }^{156}$ Idem, ibidem: "Tout le charme qu'exercent sur nous le oeuvres de l'artiste imitateur repose sur ce dangereux effet magique qui est le leur - et l'art du poète, du peintre et du sculpteur sont de fait non seulement identifiés à celui du sophiste mais encore à celui du magicien".

${ }^{157}$ Idem, ibidem, p. 43: "Car pour Platon au moins, il n'y a pas de doute que tout ce qui est beau, quelle que soit sa nature singulière, que nous le pensions comme beau de la nature ou beau de l'art, repose em dernier ressort sur des déterminations pures de nombre et de mesure. C'est ici seulement que nous touchons au fondement proprement dit de la beauté et à ses empreines les plus parfaites: car Platon n'est en rien disposé à accepter qu'une figure sensible quelconque puisse jamais égaler em beauté les figures pures de la mathématique, em particulier les corps réguliers de la stéréométrie".

${ }^{158}$ Idem, ibidem, p. 44: "Et le Philèbe reconnaît en consequénce expressément un "plaisir pur" pris à la consonance, à l'armonie et à la proportion, qui en tant que tel est d'une nature tout à fait particulière et en rien 
Todas as teorias artísticas que o sucederam mantiveram-se fiéis à correlação da arte com o belo, assumindo-a quase como um pressuposto evidente. Contudo, esta correlação na filosofia platônica rompe-se em seu oposto. ${ }^{159}$ Pois a idéia do belo para Platão está relacionada à busca pelo conhecimento, e esta vincula-se intrinsecamente à Doutrina do Amor. Tal sentimento é o meio através do qual a alma ascende à beleza, pois o amor que Platão louva não é aquele exaltado pelo poeta ou pelo criador de formas, mas o amor pela arte socrática, a arte da dialética. ${ }^{160}$ Nesse sentido, o verdadeiro Eros, de acordo com Platão, não se assemelha ao amor corpóreo que inflama de início aquele a quem desperta, mas surge como conseqüência da beleza do corpo que ascende em direção à da alma, à beleza das ações, das aspirações e do conhecimento. ${ }^{161}$ De acordo com Cassirer, somente com o Neoplatonismo a Doutrina do Amor conseguiu sua plena eficácia, ao propor que o verdadeiro amor é aquele que se torna criador. ${ }^{162}$ Segundo os neoplatônicos, toda verdadeira energia espiritual no homem, não importa qual direção tome, manifesta-se no pensamento, no agir ou no formar, e portanto, é força produtiva. Não é a posse, nem a simples intuição do belo, mas a "gestação do belo" é o objetivo para o qual o verdadeiro Amor propende. ${ }^{163}$ Esta premissa atribui nova consideração ao papel do artista, contrapondo-se em certo sentido à crítica de Platão ao seu ofício mimético, uma vez que se a energia espiritual é força criativa, então o domínio da arte não se restringe à mera reprodução do mundo sensível, mas abrange uma função igualmente criadora como forma autônoma de representação.

comparable avec la sensation du plaisir sensible. L'authentique beauté n'est pas ce que le plus grand nombre entendra par là, à savoir la beauté des corps vivants ou de certains tableaux, mais la beauté de surfaces et de corps déterminés par le mètre et le degré".

${ }^{159}$ Idem, ibidem, p. 45: "Toutes les théories de l'art ultérieures maintiennent la corrélation avec le beau qu'elles acceptent presque comme un présupposé évident. Pour Platon em revanche, cette corrélation s'inverse en son contraire".

${ }^{160}$ Idem, ibidem, p 46: 'L'art de l'amour qu'il loue n'est pás celui du poète ou du créateur de formes, mais c'est l'art socratique, l'art de la dialectique".

${ }^{161}$ Idem, ibidem: 'L'Eros authentique ne s'en tient pás à la première figure physique sensible qui l'enflamme au départ; il est poussé plus loin que la beauté du corps vers la beauté de l'âme, vers la beauté des actions, des efforts, des connaissances".

${ }^{162}$ Idem, ibidem, p. 50: "Qu'un seul motif intellectuel soit ici encore brièvement esquissé, déjà vivant en Platon lui-même bien qu'il ne soit parvenu à sa pleine efficace que dans le neo-platonisme. La pensée fondamentale de la théorie platonicienne de l'amour est que tout eros authentique doit être un eros créateur".

${ }^{163}$ Idem, ibidem, p. 51: "Ce n'est pas la possession ni la simple contemplation du Beau qui sont visées par l'eros vrai, mais "la création dans le Beau". Car tous les hommes sont féconds selon le corps et selon l'âme, et quand nous sommes en âge, notre nature tend à la génération [...]”. 
Não somente o Renascimento partiu da ascensão da alma à idéia do belo para elaborar uma compreensão mais profunda de Platão, mas também sucessivamente todas as grandes épocas de criação artística e de reflexão sobre a arte retornam sempre à doutrina platônica do Eros, como a autêntica teoria que pode creditar e justificar especulativamente toda representação artística. ${ }^{\mathbf{1 6 4}}$ No século XV a premissa de uma ligação da beleza com amor ficou a cargo da filosofia de Marsilio Ficino, ${ }^{\mathbf{1 6 5}}$ o qual partindo dos estudos das obras de Platão e Plotino definiu a Idea como sendo uma luz divina que se reflete nos anjos, nas almas e nas matérias do mundo. ${ }^{\mathbf{1 6 6}} \mathrm{O}$ esplendor e a graça da face de Deus que neles se infunde devem ser denominados, de acordo com Ficino, beleza universal e o anseio a que a esta beleza se dirige deve chama-se amor universal. ${ }^{167}$

É também a partir do Renascimento que começa a surgir uma nova especulação de teoria da arte, que baseando-se no próprio Platão e voltando-se sempre a ele, ${ }^{\mathbf{1 6 8}}$ reivindica para o mundo da arte a justificação teórica e sistemática que Platão lhe havia refutado. ${ }^{169} \mathrm{E}$ este fato ocorre com a transformação que o conceito de Idea assume neste período.

\footnotetext{
${ }^{164}$ Idem, ibidem, p. 46: "La Renaissance n'est pas seule à être parvenue, à partir de là, à la compréhension plus profonde de Platon; plus tard aussi, toutes les grandes époques de la création artistique et de la réflexion sur l'art sont toujours revenues à la théorie platonicienne de l'eros comme authentification proprement spéculative et justification de toute configuration artistique".

${ }^{165}$ Segundo Panofsky, a filosofia de Ficino apresentava uma visão de mundo bastante eclética, considerando Platão muito mais como um cosmólogo e teólogo do que um filósofo crítico; não havia tentado distinguir o platonismo do neoplatonismo, e confundia num mesmo conjunto Platão e Plotino, a cosmologia da Grécia antiga e mística cristã, os mitos homéricos e a Cabala judaica, a ciência árabe da natureza e a escolástica medieval. Cf. PANOFSKY, Erwin, op. cit., p. 52.

${ }^{166}$ PANOFSKY, Erwin, op. cit., p. 126 e nota 305. Ficino em sua obra Sopra lo amore ou Convito de Platão define deste modo a noção de Idea e o correlato conceito de beleza: "Neles (nos Anjos e nas almas), encontrase a figura de uma esfera qualquer, do Sol, da Lua e das Estrelas, dos elementos, das pedras, das árvores e dos animais. Essas pinturas denominam-se, nos anjos, modelos e idéias; nas almas razões e noções; na matéria do mundo, imagens e formas. Essas pinturas são claras no mundo, mais claras na alma e claríssimas no anjo. É, pois, uma mesma face de Deus que se reflete em três espelhos hierarquicamente ordenados, no Anjo, na alma e no corpo mundano: no primeiro, que é também mais próximo de Deus, de forma muito clara; no segundo, que está mais afastado, de forma menos clara; e no terceiro, que é o mais afastado de todos, de forma bastante obscura".

${ }^{167}$ Idem, ibidem, p. 127: "O esplendor e a graça dessa face (de Deus), quer se encontre no Anjo, na alma ou na matéria mundana, devem ser chamados de Beleza universal, e o apetite que a ela se dirige deve ser chamado de Amor universal".

${ }^{168}$ PANOFSKY, Erwin, op, cit., p. 54: "Pode-se afirmar, com base, que a teoria da arte do Pré-Renascimento (principalmente em relação a Alberti) não sofreu muito, no conjunto, a influência do despertar neoplatônico; ela se ligou, por um lado, a Euclides, Vitrúvio e Alhazen, por outro a Quintiliano e Cícero, mas não a Plotino nem a Platão, que Alberti designa ainda simplesmente como pintor [...]”.

${ }^{169}$ Idem, ibidem, p. 51: "Alors, à partir de la Renaissance, une nouvelle forme d'esthétique et de la théorie de l'art voit le jour qui, s'appuyant sur Platon lui-même et retournant constamment le regard vers lui, obtient pour le monde de l'art lui aussi la "justification" théorique et systématique que Platon lui a refusée et que, partant des présuppositions systématiques de sa doutrine, il devait lui refuser".
} 
Em consonância ao exposto por Panofsky, uma nova concepção da essência da Idéia platônica verifica-se com Filipe Melanchthon (1497-1560), quando ele estabelece uma analogia entre o termo Idea, na maneira como é exposta no pensamento de Platão, “à imagem incomparavelmente bela do corpo humano que se encontra encerrada no espírito de Apeles". ${ }^{170}$ Esta interpretação ele a tomou por base em Cícero, que foi de fato o responsável pela inversão do significado originário do termo. No Orador a Brutus, com o propósito de discorrer sobre o perfeito orador, Cícero o compara a uma "idéia" à qual não se pode alcançar por meio da experiência, sendo representada apenas no espírito. De modo semelhante, ele traça idêntico raciocínio com o objeto da representação artística, afirmando que "também este objeto não pode ser apreendido pelo olhar em sua total perfeição, existindo antes como simples imagem mental na interioridade do artista”. Declara Cícero:

"Penso que não existe em parte alguma algo de tão belo cujo original de que foi copiado não seja ainda mais belo, como é o caso de um rosto em relação a seu retrato; mas não podemos apreender esse novo objeto nem pela visão, nem pela audição ou qualquer dos outros sentidos; ao contrário, é apenas em espírito e em pensamento que o conhecemos[...]" ${ }^{171}$

Ao mencionar as obras de Fídias, ele acrescenta:

"quando esse artista trabalhava na criação de seu Zeus e de sua Atena, ele não considerava um homem qualquer realmente existente que teria podido imitar, mas em seu espírito é que residia a representação sublime da beleza [...] Assim como o domínio das artes plásticas propõe algo de perfeito e de sublime, de que existe uma forma puramente pensada [...] assim também é em espírito apenas que contemplamos a forma da perfeita eloqüência [...]". ${ }^{172}$

\footnotetext{
${ }^{170}$ PANOFSKY, Erwin, op. cit., p. 12, como também a nota 13.

${ }^{171}$ Idem, ibidem, p. 15 e 16.

${ }^{172}$ Idem, ibidem.
} 
É por meio de Cícero que o conceito de Idea transforma-se em Ideal. Se, de acordo com Platão, a idéia de beleza jamais poderia ser encontrada nas formas do mundo sensível, por ser este apenas uma sombra daquele das Idéias, ao qual a verdadeira beleza pertenceria, conforme Cícero, a configuração de uma beleza Ideal deixa de pertencer àquele mundo supraceleste para residir no interior do artista, o qual então transforma-se de imitador do mundo natural em um criador, devido ao fato de encerrar-se

“em seu espírito um modelo prestigioso de beleza para o qual ele pode voltar seu olhar; e, embora a perfeição total desse modelo não possa passar para a obra no momento da criação, esta deve no entanto, revelar uma beleza que é algo mais que a simples cópia de uma 'realidade' encantadora [...] é não obstante algo além do que o puro reflexo de uma 'verdade' que só é fundamentalmente cognoscível pelo intelecto". ${ }^{173}$

A argumentação de Cícero leva a dois caminhos de investigação: se a idéia de beleza é inata ao espírito do artista desde sempre, ou se ela é fruto de árduo estudo e experiência do ofício.

Como exposto no capítulo primeiro, em sua correspondência acerca da "imitação" com Pietro Bembo, Giovanfrancesco Pico, adotando Cícero enquanto paradigma da escrita ideal, opta pelo primeiro caminho, assimila sua premissa de que semelhante à idéia de uma linguagem correta, da bela palavra e da bela escrita, o homem possui inata em sua alma a idéia de beleza. Bembo, por sua vez, elege o segundo percurso e refuta o raciocínio de Pico ao afirmar que as idéias defendidas por ele não são por natureza pertencentes à alma do homem, mas que lhe é permitido formulá-las e conquistá-las mediante longa e penosa fadiga de estudos. Alberti, no século anterior, havia já exposto que o alcance de um ideal de beleza da figura humana (dispersa em vários corpos e não concentrada num único) através da faculdade de perceber em espírito esta beleza, somente poderia se verificar mediante o árduo estudo da natureza, a experiência e o exercício. ${ }^{174}$

\footnotetext{
${ }^{173}$ Idem, ibidem, p. 17.

${ }^{174}$ ALBERTI, Leon Battista, op. cit., p. 107: "Per questo gioverà pilliare da tutti i belli corpi ciascuna lodata parte et sempre, ad imparare molta vaghezza, si contenda con istudio et con industria, qual cosa bene che sia difficile, perché nonne in uno corpo solo si truova compiute bellezze ma sono disperse et rare in più corpi,
} 
De modo semelhante para nossos tratadistas, um modelo de beleza perfeita constróise na mente do artífice em decorrência de muito esforço e árduo trabalho no estudo e imitação da natureza, o que o nivela à proposição de Bembo. Mas somente empenho não basta, pois o artífice deve ser dotado por nascimento de agudo engenho ou determinada propensão, denominada talento para as artes (como declarado anteriormente por Pino e Dolce), o que implica dizer ser capacitado por natureza de um tipo especial de discernimento/juízo/intuição mais aguçado do que os demais indivíduos da espécie, a fim de poder levar a termo seu ofício. Dolce chega inclusive a afirmar que sem este dom, por mais que o artífice se esforce nunca deixará de ser mediano. ${ }^{175}$

A despeito da observação acima, observamos que o termo Idea está presente nos tratados, mencionado no corpo dos argumentos de modo a demonstrar conotações implícitas ao pensamento platônico, sem, no entanto, apresentar maiores digressões filosóficas.

Em sua defesa da pintura enquanto arte liberal, Pino faz uma tentativa meio obscura de explicar a razão pela qual a pintura vincula-se ao intelecto, sendo concebida primeiramente enquanto conceito na mente do artífice. Em suas palavras:

"o artífice não pode produzir na arte efeito algum que resulte unicamente de sua imaginação, se primeiramente aquilo que imaginou não provier dos outros sentidos intrínsecos e sendo reconduzido à presença da idéia com a mesma integridade com a qual há de se produzir, de tal maneira que o intelecto a compreenda perfeitamente em si mesmo, sem passar por fora daquilo que lhe é próprio, que é a faculdade intelectiva". ${ }^{176}$

\footnotetext{
pure si debba ad investigarla et impararla porvi ogni faticha. Interverrà come a chi s'ausi volgiere e prensere cose maggiori, che facile costui potrà le minori né truovasi cosa alcuna tanto difficile, quale lo studio et assiduità non vinca". Cf. também PANOFSKY, Erwin, op. cit., p. 58.

175 DOLCE, Lodovico, op. cit., p.187: "Parmi che basti, non solo a perfettamente giudicar, ma anco a perfettamente dipingere, questo tanto che n'avete favellato, percioché le altre cose per lo più consistono nell'esercizio e nella pratica. E fra quante mi avete detto me ne piacciono sommamente due: l'una, che bisogna che le pitture movano; l'altra, che'l pittore nasca. Percioché ci si veggono molti, che alla parte della industria non hanno mancato e si sono affaticati lungo tempo ne' rilievi e nelle cose vive, e mai non hanno potuto passare un mediocre termino; altri, che per un tempo hanno dimostro principi grandissimi et hanno caminato un pezzo avanti, scorti dalla natura, e poi, da lei abandonati, sono tornati all'indietro, riucendo nulla". Cf. Anexo, p. 132-133.

${ }^{176}$ PINO, Paolo, op. cit., p. 10: “[...] fu la pittura tra quelle (arti liberali) celebrata e approbata da tutti e'filosofi, come referisce Laertio, Diogene e Demetrio. Et che così sia, la ragione è ch'uno pittore non può
} 
Depreendemos que, conforme Pino, o pintor deve imitar as formas naturais para compor sua obra e não produzi-la unicamente em decorrência de sua imaginação. O que é pensado por ele deve primeiro provir de seus sentidos como resultado do que estes captam e acolhem do mundo natural, para depois ser direcionado ao campo da idéia. Tal processo deve ser realizado de maneira íntegra sem ser contaminado pela fantasia, de forma que o cérebro tenha plena compreensão das imagens apreendidas pelos sentidos, sem passar à margem da característica que lhe é peculiar que é a faculdade intelectiva ou juízo. Idéia, de acordo com Pino, é a configuração mental ou imagem/esboço das formas que o artífice pretende representar na pintura; não é um dado inato, edifica-se no cérebro em decorrência do exercício e da experiência. Não é ao conceito platônico que Pino retoma, mas sim aos postulados de Alberti.

Se este é o processo devido ao qual a pintura vem à luz conforme os critérios de Pino, é possível afirmar igualmente que a criação de um modelo de beleza feminina ocorra nos mesmos parâmetros, uma vez que ao citar a anedota de Zêuxis ele insinua que, além da imitação, só através da eleição das partes mais belas capturadas da natureza pelo artífice é que ele encontra a viabilidade de criar um ideal de beleza perfeita em sua mente.

A menção de Zêuxis e sua representação da imagem de Helena, em que imitação, eleição e superação da natureza estão envolvidos, é fonte relevante na discussão da tópica de uma beleza ideal, por ser o vínculo que une a questão da mimesis aristotélica ao conceito de Idea platônica, tendo sido mencionada por vários autores antigos e modernos, como Cícero, Plínio, Ghiberti, Alberti, Vasari, Gilio.

Segundo Pasquale Sabbatino, a anedota de fonte ciceroniana foi importante topos da tratadística sobre as artes figurativas e a arte da escrita, apresentando três implicações: primeiro, a evidência de uma pluralidade dos modelos escolhidos por Zêuxis ao observar a natureza. Segundo, a beleza ideal que o artífice possui em sua mente. E terceiro, a figura de Helena, ou a realização da beleza perfeita. Essas implicações levaram a três reviravoltas de ordem interpretativa pelos tratadistas: havia aqueles que defendiam a imitação da natureza e

nell'arte nostra produrre effetto alcuno della sua imaginativa, se prima quella così imaginata non vien dagli altri sensi intrinseci, ridotta al conspetto dell'idea con quella integrità, ch'ella s'hà da produrre, tal che l'intelletto l'intende perfettamente in se stesso, senza mecare fuori del suo proprio, ch'è l'intendere [...]'. Cf. Anexo, p. 31-32. 
da pluralidade de modelos oferecidos (como no caso de Pino e Dolce); outros optaram pela imitação da idéia, e outros ainda que se declaravam a favor da imitação de um modelo perfeito (nesse sentido podemos incluir também Dolce por preceituar ao pintor a imitação da estatuária antiga enquanto paradigma de perfeição). ${ }^{\mathbf{1 7 7}}$

No que se refere ao conceito de Idea conforme o diálogo de Dolce, Mark Roskill afirma que seu conhecimento de Cícero e sua familiaridade com os escritos de Pietro Bembo fizeram com que ele desse uma importância um pouco maior a algumas noções do pensamento platônico, mas sua frágil compreensão de filosofia não o capacitava a desenvolver sua teoria da arte sob a influência de seu pensamento, de modo a diferenciá-la largamente dos pressupostos colocados por Vasari em sua obra. ${ }^{178}$ Dolce retoma Platão ao utilizar o termo Idea em dois momentos e ao aplicar a máxima de que o "poeta nasce, não se faz". Ao sugerir de modo vago o argumento de que Deus é o supremo artífice, e em outra passagem estabelecer uma analogia do gênio de Michelangelo com a luz do sol que ofusca a luz de outros artífices (na qual de acordo com Roskill representa uma metáfora do "Mito da Caverna" de Platão). ${ }^{\mathbf{1 7 9}}$ E em outro trecho Roskill declara que o receio de Dolce por um declínio da arte indicaria uma adesão à visão platônica, dado que para o filósofo grego, a "essência" do processo artístico estaria identificada com um modelo supremo e portanto limitada no avanço de progressos. ${ }^{\mathbf{1 8 0}}$

\footnotetext{
${ }^{177}$ SABBATINO, Paquale, op. cit., p. 7: "L'aneddoto di Elena dipinta da Zeusi, che dapprima seleziona le cinque vergini più belle di Crotone e poi preleva da ciascuna la parte più perfetta, divenne nel Rinascimento um topos della trattatistica sulle arti figurative e sull'arte della scrittura. La fonte ciceroniana tramanda una storia dalla struttura trimembre, di cui il primo modulo evidenzia la pluralità dei modelli scelti da Zeusi osservando la natura, il secondo la bellezza ideale che l'artista ha nella mente, il terzo la figura di Elena ovvero la realizzazione della bellezza perfetta. Per questo l'episodio si rivelò sostanzialmente ambiguo e fu utilizzato con vere e proprie capovolte interpretative sia da quanti sostennero l'imitazione della natura e della pluralità dei modelli offerti, sai da quelli che puntarono sull'imitazione dell'idea, sai dagli altri che si schierarono a favore dell'imitazione del modelo perfetto".

${ }^{178}$ ROSKILL, Mark W., op. cit., p. 11: "Dolce's knowledge of Cicero, and also his familiarity with the writings of Bembo, invite one to expect in his Dialogue something of a major stress upon Platonism. But it is clear that his grasp of philosophy was too weak to enable him to develop his theory of art, under the influence of Platonism, along any such lines as would create real diferences between him and Vasari".

${ }^{179}$ Idem, ibidem: "He uses the term Idea twice and applies the proverb poeta nascitur, non fit. There are a few passages dimly suggesting his conversancy with the argumentum ex universo, according to which God is the supreme artist, and one in which he speaks of the genius of Michelangelo in vaguely Platonic terms comparing it to the light of the sun which dims all other lights, a metaphor with its ultimate source in Plato's Allegory of the Cave".

${ }^{180}$ Idem, ibidem: "But one can scarcely consider that his fear of a decline of art marks an allegiance to the Platonic view that, since the "essence" of art is identifiable with one supreme model, there must be fixed limits to the possibility of artistic progress".
} 
Nos dois momentos em que Dolce cita o termo Idea, seja ao discutir certa contenda sobre o desenho entre Rafael e Sebastiano del Piombo, ${ }^{\mathbf{1 8 1}}$ seja ao relatar que em sua juventude Ticiano já possuía a idéia de um pintar perfeito, em ambas as passagens, ele apenas insinua o conceito platônico transformado por Cícero. ${ }^{182}$ E pela importância que o tratadista confere ao papel de Rafael ao seu Diálogo, consideramos pertinente ilustrar a temática da Idea no próprio depoimento de um artífice (direcionado à concepção de um ideal beleza feminina), no caso o que Rafael expôs a respeito do termo na célebre epístola enviada a Castiglione. A carta enuncia como um ideal de beleza perfeita desponta em seu intelecto, contudo, Rafael não demonstra claramente como se verifica o percurso de seu processo mental. Ele diz:

"Sobre Galatea, tornar-me-ía um grande mestre se tivesse metade dos tantos atributos dos quais Vossa Senhoria me descreve, mas em suas palavras reconheço a afeição que tendes por mim e digo-vos que, para pintar uma bela mulher, me seria necessário ver as mais belas e com esta condição: de que Vossa Senhoria estivesse comigo a fim de me ajudar a fazer a escolha da melhor. Mas, havendo uma carência não só de bons juízos, como também de belas mulheres, sirvo-me de uma certa idéia que me vem à mente. Se esta tem em si alguma excelência de arte, eu não sei, porém, afadigo-me por obtê-la". 183

${ }^{181}$ DOLCE, Lodovico, op. cit., p. 151: "Ricordami che, essendo Bastiano spinto da Michelagnolo alla concorrenza di Rafaello, Rafaello mi soleva dire: "Oh quanto egli mi piace, M. Pietro, che Michelagnolo aiuti questo mio novello concorrente, facendogli di sua mano i disegni! Percioché dalla fama che le sue pitture non istiano al paragone delle mie potrà avedersi molto bene Michelagnolo ch'io non vinco Bastiano (perché poca loda sarebbe a me di vincere uno che non sa disegnare), ma lui medesimo, che si reputa, e meritamente, la Idea del disegno". Cf. Anexo, p. 101.

182 Idem, ibidem, p. 202: "E certo si può attribuire a miracolo che Tiziano, senza aver veduto alora le anticaglie di Roma, che furono lume a tutti i pittori eccelenti, solamente con quella poca favilluccia ch'egli aveva scoperta nelle cose di Giorgione, vide e conobbe la idea del dipingere perfettamente". Cf. Anexo, p. 146-147.

${ }^{183}$ BAROCCHI, Paola. Scritti D’Arte del Cinquecento. Tomo II. Milano, Napoli: Riccardo Ricciardi Editore, p. 1529-1530: "[...] Della Galatea mi terrei un gran maestro, se vi fossero la metà delle tante cose che Vostra Signoria me scrive; ma nelle sue parole riconosco l'amore che mi porta, e le dico che, per dipingere una bella, mi bisogneria veder più belle, con questa condizione: che Vostra Signoria si trovasse meco a far scelta del meglio. Ma, essendo carestia e di buoni giudici e di belle donne, io mi servo di certa idea che mi viene nella mente. Se questa ha in sé alcuna eccellenza d'arte, io non so; ben m'affatico di averla [...]”. 
Por ser talvez um dos únicos testemunhos sobre como uma concepção de beleza se forma na mente do artífice, esta carta peculiar de Rafael deu margem a algumas interpretações por parte dos estudiosos. De acordo com Pasquale Sabbatino, seu conteúdo alude diretamente ao problema da imitação proposto pela polêmica criada entre Giovanfrancesco Pico e Pietro Bembo. Apesar de não conter vestígio manifesto à doutrina platônica, a carta de Rafael está por ela substancialmente impregnada. Em suas palavras, a imitação da natureza não é suficiente para obter a representação de um ideal de beleza, tampouco a imitação eclética e seletiva realizada por Zêuxis, porque, em sua opinião, sua época carece tanto de belas mulheres quanto de bons juízos, habilitados em avaliar a beleza singular de cada uma. Portanto, ele atribui um papel determinante à idéia de beleza que lhe "vem à mente" e à capacidade do artífice de dar forma àquela idéia de beleza ou "íntima representação", sem recorrer à imitação da natureza e sem deixar-se subjugar pelos estímulos que vêm do exterior. ${ }^{\mathbf{1 8 4}}$

Erwin Panofsfy, por seu turno, enfatiza o fato de Rafael ter reconhecido a possibilidade de deduzir unicamente de uma "íntima representação" a imagem da perfeita feminilidade, independente do objeto exterior singular, e sem explicar a maneira como ele concebia a relação entre a "Idéia" e "experiência". Todavia, segundo o historiador, ao acolher o "conceito de idéia", Rafael deixa de enfrentar duas problemáticas. Primeiro, se a origem da idéia de beleza decorre de um processo físico ou de uma origem metafísica, e segundo, se esta "representação interior" apresenta qualquer "validade" ou "veracidade". 185

Ernst Gombrich admite existir na epístola de Rafael alguns elementos de ordem platônica, a despeito de não haver menções mais explícitas a respeito. De acordo com o historiador, o ponto de referência de Rafael não é Platão, nem Marsilio Ficino, mas a correspondência entre Pico e Bembo (raciocínio com o qual concorda Sabbatino). E as palavras de Rafael talvez façam alusão a uma passagem precisa da epístola de Pico onde ele afirma (como já citado no capítulo I) que existe no ânimo do homem uma certa idéia da linguagem correta, para a qual se olha quando se julga a própria linguagem ou a de outros, assim como no pintor existe "um modelo abstrato de beleza", à qual se contempla para poder pintar um corpo belo. Tanto para Rafael como para Pico, a idéia de beleza é inata à

\footnotetext{
${ }^{184}$ SABBATINO, Pasquale, op. cit., p. 37.

${ }^{185}$ Idem, ibidem.
} 
alma do homem. Contudo, Gombrich afirma também que há um dado relevante não defrontado por Rafael com relação à origem de tal idéia, e que se trata do repertório da tradição cultural recolhido mentalmente pelo artista em seu processo de formação, como o fato de que artífices reproduzem e perpetuam inconscientemente o vocabulário visual utilizado por seu mestre, com algumas variações. O fato dos artífices ficarem anos a fio estudando e aprendendo junto a um mestre, no geral para confeccionar suas obras, faz com que eles absorvam determinados esquemas formais que sempre virão a reproduzir quando da criação de suas próprias obras.

Poder-se-ia concluir, assim, com relação ao processo de construção mental de um "ideal de beleza" (apesar das divergências de proposições dos estudiosos), que ela se verifica por meio de três caminhos: primeiro, por uma configuração inata ao espírito do artífice. Segundo, através da prática e experiência constante no imitar as formas naturais. Terceiro, por um esquema herdado da tradição cultural. Ou ainda com a segunda e terceira instâncias simultaneamente.

Colocamos até o momento de modo extremamente simplificado algumas considerações sobre a Idea e sua relação com a concepção de beleza na arte, inclusive na visão dos tratadistas. Voltamo-nos agora para a própria definição de beleza presente nos diálogos e sua conexão com um cânone de beleza feminina.

Em se tratando de uma "teoria da beleza", Robert Klein e Henri Zerner afirmaram que esta não ocupou lugar de destaque nos tratados artísticos (em particular nos escritos de pintura e escultura), porque num primeiro momento as preocupações dos artífices estavam direcionadas à criação de um vínculo entre estas artes e a poesia, bem como estabelecer critérios científicos e técnicos para sua concepção, com o objetivo de lutar contra a alcunha pejorativa de artes imitativas, com que eram denominadas. ${ }^{\mathbf{1 8 6}}$

Especulações sobre a beleza surgiram primeiramente no âmbito letrado, e, em decorrência (como já mencionado acima) do ambiente cultural a que estava relacionada a vida civil no Renascimento.

Segundo Klein e Zerner, duas correntes caracterizavam a investigação sobre a teoria da beleza, uma de tradição platônica, outra de cunho aristotélico. A primeira insistia na

\footnotetext{
${ }^{186}$ KLEIN, Robert and ZERNER, Henri. Italian Art 1500-1600 - Sources and Documents in the History of Art Series. New Jersey, Prentice-Hall, Inc., 1966, p. 177.
} 
impossibilidade de uma definição puramente formal de beleza, ligando-a aos aspectos da graça, do espírito e da vida (cujo maior expoente foi Marsilio Ficino e sua herança de Platão). A segunda era formalista e baseada na harmonia e no decoro, conectada ao aristotelismo do círculo de Pádua e representada pela figura de Agostino Nifo. ${ }^{187}$

No tocante à primeira corrente encontramos os pressupostos de Marsilio Ficino que define a beleza, ora em estreito acordo com Plotino, em que ela se traduz enquanto "semelhança evidente dos corpos com as Idéias" ou, então, como "triunfo da razão divina sobre a matéria", ora Ficino associa-a ao Neoplatonismo cristão, e como tal, a beleza transcreve-se como "raio emanado da face de Deus", que se introduz primeiro nos anjos, iluminando em seguida a alma humana e por fim o mundo da matéria corporal. ${ }^{\mathbf{1 8 8}}$

Se para Ficino, em consonância com Platão, as Idéias são realidades metafísicas e os elementos terrestres apenas suas "imagens", sendo que nós só podemos tomar consciência delas segundo impressões que existem em nossa alma desde sua existência anterior e supraterrestre, isso implica dizer (nas palavras de Panofsky) "que a Idéia do belo também está impressa em nosso espírito como uma "fórmula", e esta noção inata vinculada ao aspecto espiritual que existe em nós, nos concede a faculdade de reconhecer a beleza visível e de julgá-la em função de uma invisível beleza, tal como ela se manifesta, do "eidos" sobre a matéria: bela é a coisa que, na terra, está em harmonia mais completa com a Idéia da beleza (e ao mesmo tempo com sua idéia própria), e percebemos essa harmonia relacionando a aparência sensível à "fórmula" conservada em nós". ${ }^{189}$ A beleza é então, na visão de Ficino, um atributo espiritual e incorpóreo e portanto não vinculado à proporção da matéria corporal, pois para ele, a beleza do corpo é "uma determinada atitude, vivacidade e graça, que brilha no corpo sob a influência de sua idéia". ${ }^{190}$

A segunda corrente, conforme Klein e Zerner, corresponde a uma teoria naturalista da beleza, expressa por uma visada paduana com notável audácia e coerência por Agostino Nifo (1469-1538). A premissa exposta em sua obra De Pulchro et Amore, publicada pela

\footnotetext{
${ }^{187}$ Idem, ibidem.

${ }^{188}$ PANOFSKY, Erwin, op. cit., p. 53.

${ }^{189}$ Idem, ibidem, p. 55-56.

${ }^{190}$ Idem, ibidem, p. 131-132: “Este esplendor (a influência no corpo por meio de sua idéia) não desce até a matéria se esta não foi previamente preparada. E a preparação do corpo vivo consiste em três coisas: a ordem, o modo e a espécie ou aparência. A ordem significa a distância entre as partes; o modo significa a quantidade; a espécie significa as linhas e as cores [...] A beleza portanto está tão afastada da matéria corpórea, que só se comunicará com ela se esta estiver devidamente disposta graças a estas três preparações incorpóreas [...]”.
} 
primeira vez em 1531, é diametralmente oposta ao idealismo florentino. Na opinião de Nifo, a beleza formal é uma propriedade física dos corpos, e a beleza em geral, seja formal ou espiritual, é definida como aquela que incita ao desejo sexual e, para tanto, nem natureza, nem arte podem ser denominadas belas. Para os dois autores a argumentação de Nifo remete-se à Escolástica e seu raciocínio é pobre, mas seu radical anti-platonismo equivale à maneira como determinados diletantes venezianos comentavam as obras de Giorgione e Ticiano. ${ }^{191}$

De acordo com Nifo, não há parte precisa de um belo corpo em que a graça exista de modo certo e determinado. A graça de fato encontra-se em algumas jovenzinhas, na voz e na suavidade do falar, em outras, nos olhos, no semblante, em outras ainda, nas mãos, no modo de caminhar, nas maçãs do rosto. Em suma, a graça não se insere a nenhuma parte específica do corpo, mas àquela a qual arrebata a alma do amante ao gozo de si. Porém, pois que a alma do amante às vezes é extasiada pelas mãos, às vezes pelos olhos, às vezes pelo semblante, com isso consegue que a graça não se encontre em nenhuma parte exata do corpo, se bem que, existindo ora em uma, ora em outra parte, possa de vez em quando atrair a alma dos amantes. ${ }^{192}$ A graça é, portanto, corpórea, dado que depois do ritual do enamorar, todo o corpo da amada apresenta-se ao amante gracioso e amável. Portanto, a graça, enquanto beleza, deve ser considerada corpórea. ${ }^{193}$

Em conformidade aos peripatéticos, belo é aquilo que arrebata o ânimo ao desejo que é uma forma de amor, nada será belo se não se reportar ao desejo, que é o afeto do apetite sensitivo. Por isso, nem os substratos intelectuais, nem o céu, nem o mundo,

\footnotetext{
${ }^{191}$ KLEIN, Robert and ZERNER, Henri, op. cit., p. 178.

${ }^{192}$ BAROCCHI, Paola, op. cit. AGOSTINO, Nifo. De Pulchro in Cap. X - Bellezza e Grazia Tradução para o italiano de Paola Barocchi. p. 1658-1659: "[...] Ma la grazia in un bel corpo non ha parte in cui sia in modo certo e determinato, sì da non trovarsi in nessun'altra parte del corpo; la grazia infatti in alcune fanciulle sta nella voce e nella dolcezza del parlare, in altre negli occhi, in altre nel volto, in altre nelle mani, nel modo di camminare, nelle gote e insomma, senza che io stia qui ad enumerarle ad una a una, la grazia non inerisce a nessuna specifica parte del corpo, ma a quella con cui trascina l'animo dell'amante al godimento di sé. Ma poiché l'anima dell'amante talora è extasiada dalle mani, talora dagli occhi, talora dal volto, ne consegue che la grazia non si trova in nessuna parte del corpo, bensì ora in una ora in un'altra parte, dove ora l'una ora l'altra possono di volta in volta attrarre le anime degli amanti'".

${ }^{193}$ Idem, ibidem, p. 1659: "Ma (la grazia) è anche corporea, dato che dopo l'innamoramento tutto il corpo si presenta all'amante grazioso e amabile. Onde accade che la grazia occupa tutto il corpo dell'amata. Ma ciò che occupa tutto il corpo, è corporeo e coesteso allo stesso corpo. Pertanto dopo l'innamoramento la grazia, in quanto è bellezza, è ritenersi corporea $[\ldots]$ ".
} 
nenhum elemento que não incite ao desejo, ou que seja afetado pelo apetite sensitivo, colocar-se-á a justa razão de ser denominado belo. ${ }^{194}$

Existem algumas coisas que, ou agradam imensamente à vontade, como por exemplo aquelas que são absolutamente perfeitas e boas, como as substâncias divinas; ou agradam ao apetite sensitivo, como aquelas que nos são muito agradáveis e destinadas ao prazer. Nada é belo por natureza fora do homem. Quando de fato em um homem existem muitíssimas partes, diferentes por figura, dessemelhantes por natura, dotadas de uma relação proporcional entre elas e o todo, o seu corpo é por natureza belo. Quando, pelo contrário, as partes não têm entre si e com o todo uma relação proporcional, são estimadas feias por natureza. ${ }^{195}$ Portanto, em oposição a Ficino, a beleza, em conformidade ao pensamento de Nifo, é unicamente corpórea, residindo na proporção das partes com o todo e intrinsecamente relacionada ao desejo carnal.

Nas duas correntes acima, a beleza está vinculada às questões do amor. Em Ficino, a argumentação vincula-se ao aspecto metafísico e sacro, em Nifo, a discussão reflete-se no âmbito das características físicas e profanas. As obras de ambos autores, dois Tratados de Amor, ${ }^{196}$ impulsionaram o florescimento deste tipo de escritos, ${ }^{197}$ cuja tradição se expande com maior intensidade no século XVI, sendo o mais notável entre eles, os Diálogos de Amor, de Leon Hebreu, publicado em 1535. ${ }^{198}$ A matéria, em suas especulações de ordem

\footnotetext{
${ }^{194}$ Idem, ibidem, p. 1668: "Infatti se bello è ciò che trasporta l'animo al desiderio, il quale è una forma di amore, niente sarà belo che non si riporti al desiderio, che è l'affetto dell'appetito sensitivo. Perciò, poiché né le sostanze intellectuali né il cielo né il mondo né un elemento spinge al desiderio, che è affetto dell'appetito sensitivo, nessuna di queste cose si potrà a giusta ragione dire bella".

${ }^{195}$ Idem, ibidem, p. 1669: "Ma poiché vi sono alcune cose che o piacciono immensamente alla volontà, come per esempio quelle che sono assolutamente perfette e buone, come le stesse sostanze divine; o piacciono allo stesso appetito sensitivo, come tutte quelle che ci restano gradevolissime e piacevolissime: né le une né le altre il volgo dice mai belle. Ma, come dicemmo, niente è bello per natura fuori dell'uomo. Quando infatti in un uomo vi sono moltissime parti, distinte, differenti per figura, dissimili per natura, dotate di un rapporto proporzionale tra loro e col tutto, il suo corpo è per natura bello. Quando invece le parti non hanno tra di loro e col tutto un rapporto proporzionale, è stimato brutto per natura".

${ }^{196}$ O Comentário sobre o Banquete de Platão, (1469), de Ficino e Da beleza e do Amor, (1531), de Nifo.

${ }^{197}$ GEBHARDT, Émile. Les Origines de la Renaissance en Italie. Paris, Librairie Hachette et Cie., 1879, p. 1, citado por ALVES, Luiz Roberto. Diálogos de Amor - Humanismo e Exílio em Jehuda Abravanel. São Paulo, FAPESP, EDUSP e Nova Alexandria, 1997, p. 36: “[...] los trattati d'amore del Cinquecento no se dirigen a los doctos, sino a la sociedad, y no sólo pretenden ser il instrumento que transmite la filosofia platonizante del amor, sino que quieren también educar en las bellas maneras para una cultura centrada en la mujer, siendo por ello su influjo más vasto de lo que puede esperarse de obras filosóficas. Pero precisamente entre los trattati d'amore ninguno alcanzó el éxito logrado por el único que es obra de un verdadero filósofo: los Dialoghi d'Amore, de León Hebreo".

${ }_{198}$ NIFO, Agostino. De Pulchro et amore; De Pulchro Líber; Du Beau et de L'Amour; Le Livre du Beau. Édition critique, traduction, introduction et notes par Laurence Boulègue. Paris, Société d'édition Les Belles
} 
espiritual ou carnal e sua íntima relação com um cânone de beleza feminina, torna-se um dos temas de dissertação favoritos entre homens e mulheres cultos daquela sociedade civil do século XVI. ${ }^{199}$

Envoltos no influxo dessas especulações encontram-se nossos tratadistas Pino e Dolce, seja pelos ecos das palestras realizadas no Vêneto por Benedetto Varchi, sendo uma delas sobre a beleza e a graça, ou mais especificamente no caso de Dolce por ter sido ele responsável pela edição de outro importante tratado sobre o amor, o Libro di natura d'amore, de Mario Equicola, de 1554, de recorrência também platônica.

As idéias de Ficino parecem não ter deixado muitos resquícios em Pino e Dolce, pois o conceito de beleza que ambos defendem está mais próximo das premissas de Agostino Nifo e da premissa de Aristóteles. ${ }^{200}$

A beleza nas palavras de Paolo Pino define-se como um produto de linhas, proporções, medidas e ordens que a natureza imprime em suas obras. ${ }^{201}$ Expressa-se em toda espécie criada por uma comensuração e correspondência de membros concebidos pelo mundo natural sem acidentes. A beleza resultaria então de uma disposição e harmonia das partes em sua proporcionalidade, tanto em seu aspecto individual quanto da relação destas partes com o todo da figura, raciocínio equivalente ao proposto por Alberti. ${ }^{\mathbf{2 0 2}}$

Lettres, 2003, p. LIV: "Les premiers échos au Commentaire de Ficin furent, au début du XVIe. siècle, le Commentaire sur une chanson d'amour de Pic de la Mirandole, en 1500, et les Dialoghi d'amore de Léon l'Hébreu, écrits entre 1501 et 1506 et publiés à Rome en 1535, deux tentatives réelles de pénétrer la penseé du philosophe".

${ }^{199}$ Idem, ibidem, p. LIII: “Avec le Commentaire sur le Banquet de Platon ou De Amore de Marsile Ficin, em 1469 , le thème de l'amour devint l'un des sujets de conversation favoris de la haute société du XVIe. siècle italien". "[...] A l'origine de la redécouverte de Platon par ses contemporains, Ficin, par la puissance de sa propre vision de toute la tradition platonicienne et néo-platonicienne, a assurément impressionné et influencé les humanistes de son temps, même au-delà de l' Italie, et séduit un public cultivé et raffiné, gagné par un regain d'intérêt pour la beauté, l'amour, et la culture antique".

${ }^{200}$ ARISTÓTELES, op. cit., p. 76-77: "Além disso, o belo, - ser vivente ou o que quer que se componha de partes -, não só deve ter essas partes ordenadas, mas também uma grandeza que não seja qualquer. Porque o belo consiste na grandeza e na ordem, e portanto, um organismo vivente, pequeníssimo, não poderia ser belo (pois a visão é confusa quando se olha por tempo quase imperceptível); e também não seria belo, grandíssimo (porque faltaria a visão do conjunto, escapando à vista dos espectadores a unidade e a totalidade; imagine-se, por exemplo, um animal de dez mil estádios ...). Pelo que, tal como os corpos e organismos viventes devem possuir uma grandeza, e esta bem perceptível como um todo, assim também os mitos devem ter uma extensão bem apreensível pela memória".

${ }^{201}$ PINO, Paolo, op. cit., p. 4: "Ben sapete, che quanto all'humor de noi pittori, la bellezza de tutte queste done raccolta insieme non sopplirebbe per formar una bella femina à nostra sodisfattione, volendo imitar quelle linee, proportioni, misure e ordini astratti quasi del vero, ch'i primi nostri inventori, per immortalarsi, istituirono le cose a modo loro, ben che l'inventione fossero (se dir si può) divine". Cf. Anexo, p. 8.

${ }^{202}$ PANOFSKY, Erwin, op, cit., p. 197, nota 123: Em sua obra De Re Aedificatoria, IX, 5, Alberti afirma: "[...] Podemos portanto afirmar que a beleza é um acordo e uma conspiração das partes que compõem a coisa, 
A concepção de uma beleza racional equacionada por meio de uma teoria das proporções e exemplificada pelo cânone de Vitrúvio, como se verifica nos tratados de Pino e Dolce, foi de suma importância para a criação artística do Renascimento, sendo tema recorrente na Literatura do período. ${ }^{203}$

Em conformidade ao cânone vitruviano e seguindo o procedimento seletivo de Zêuxis em sua eleição das partes mais belas da natureza, o tema da beleza no tratado de Pino tem por objetivo prescrever um paradigma de beleza feminina. Seu modelo de figuração assemelha-se à descrição que Agnolo Firenzuola realiza em seu Dialogo delle bellezze delle donne, publicado em 1541:

"Parece-me que, para um corpo feminino ser perfeitamente belo, é necessário que a natureza não seja impedida ao produzi-lo e que a matéria seja bem disposta em qualidade e quantidade; que seja gerada em boa conjunção com as sete estrelas e sob o benigno influxo dessas segundas causas; de igual compleição com apropriada proporção; que os humores superficiais sejam temperados de modo que deles se cause uma carne delicada, sem mácula, lúcida e cândida; que a idade não atinja os trinta e cinco anos, contudo mais participe do imaturo do que do maduro; não debilitada pelo coito, não gorda, não seca; que os membros se correspondam em conjunto; com os cabelos longos, finos e áureos, as maçãs do rosto iguais, a boca reta, os lábios de puro sangue e pequenos; os dentes cândidos

conforme um número, uma delimitação e uma disposição definidos e exigidos pela harmonia, isto é, pela razão absolutamente primeira da natureza". Em outro trecho da mesma obra, cap. VI, 2, ele afirma: "Eis aqui, brevemente, a definição que iremos propor: a beleza é uma harmonia racionalmente determinada de todas as partes que compõem a coisa, de modo a se tornar muito improvável que algo possa ser acrescentado, suprimido ou alterado".

${ }^{203}$ PANOFSKY, Erwin, Significado nas Artes Visuais. Cap. II: A História da Teoria das Proporções Humanas como reflexo da História dos Estilos. São Paulo, Editora Perspectiva, 1979, p. 129-130: “A teoria das proporções humanas era vista tanto como um requisito da criação artística quanto como uma expressão da harmonia preestabelecida entre o microcosmo e o macrocosmo; além do mais, era vista como a base racional para a beleza. Podemos dizer que a Renascença fundia a interpretação cosmológica da teoria das proporções, corrente nos tempos helenísticos e na Idade Média, com a noção clássica da "simetria"como princípio fundamental da perfeição estética. Do mesmo modo que se procurou uma síntese entre o espírito místico e o racional, entre o neoplatonismo e o aristotelismo, assim também a teoria das proporções foi interpretada, quer do ponto de vista da cosmologia harmônica, quer da estética normativa; parecia transpor a brecha existente entre a fantasia do final do helenismo e a ordem clássica de Policleto. Talvez a teoria das proporções parecesse tão infinitamente valiosa para o pensamento da Renascença precisamente porque apenas essa teoria - matemática e especulativa ao mesmo tempo, - poderia satisfazer as diversas necessidades espirituais da época". 
e iguais, as orelhas no seu termo, o qual vai da ponta do nariz até o canto do olho, e sejam baixas; o pescoço redondo e liso; o peito amplo e macio, os seios firmes e separados, os braços expeditos; as mãos delicadas com os dedos distendidos, um tanto diminuídos nos extremos, com unhas mais longas do que largas; o corpo pouco levantado e firme, as coxas adelgaçadas e marmóreas". 204

Por meio dessa palavras, Pino traça um esboço sensual da figura feminina, como se tivesse na mente as personagens repletas de sensualidade representadas por Giorgione e Ticiano. O conceito de beleza para ele restringe-se, assim, puramente ao aspecto físico apresentando de modo simultâneo um apelo carnal, próximo às noções de Nifo, pois em certo trecho do diálogo, após tecer esta descrição, um dos interlocutores diz ao outro: "E então, (a imagem que lhe passo) não lhe desperta o desejo?",205 Numa breve passagem, e apesar de uma pequena confusão filosófica, Pino une a beleza à virtude moral (o bem), no que ele retoma o proposto por Sócrates ao agregá-la a uma conotação moral e ética, ao afirmar que: “outra coisa é além disso a bondade intrínseca, a qual está ligada à proporção aqui já citada, de tal modo que a beleza faça fé à bondade. E diz Aristóteles que um corpo monstruoso é indigno de uma alma reta". 206

Em se tratando de Dolce, o percurso discursivo é semelhante. Beleza, segundo ele, origina-se de uma conveniente proporção que, de modo comum apresenta o corpo humano, e particularmente todo membro entre si, sendo a ausência desta qualidade causada por sua

\footnotetext{
${ }^{204}$ PINO, Paolo, op. cit., p. 7: "Par a me, ch'um corpo feminille a esser perfettamente bello, non bisogna che la natura sai nel produrlo impedita, et che la matéria sia ben disposta di qualità e quantità, che sia generata in buona congiontione delle sette stelle, et sotto benigno influsso di queste seconde cause, d'equal complessione in própria portione, che gli humori superficiali siano temperati di modo, che da loro si causi una carne delicata, senza macola, lucida e candida, che l'età non aggiugnia alli trentacinque anni,ma più partecipi dell'acerbo, che del maturo, non debilitata dal coito, non pasuta, non arida, che le membra corrispondano insieme; con i capelli lunghi, sottili e aurei, le guancie uguali, la bocca retta, le labra di puro sangue e picciole, i denti candidi e eguali, l'orecchie nel suo termine, il qual è dalla punta dell naso infin alla coda dell'occhio e siano basse, la gola rotonda e liscia, il petto amplo et morbido, le poppe sode e divise, le braccia ispedite, le mani delicate com le dita distese, alquanto diminuite negli estremi con ugnie più lunghe che larghe, il corpo poço rilevato et sodo, le coscie affusate et marmoree". Cf. Anexo, p. 18-20.

${ }^{205}$ Idem, ibidem: "Vi si ricciava l'appetito, eh?". Cf. Anexo, p. 21.

${ }^{206}$ Idem, ibidem, p. 7: A premissa é socrática e não aristotélica. "[...] altro è poi la bontà intrinseca, la qual è conessa nella portione dechiaritavi, tal che la bellezza fà fede alla bontà. Et dice Aristotile, ch'un corpo mostruoso è indegno d'una anima retta. Cf. Anexo, p. 21.
} 
desproporção. ${ }^{\mathbf{2 0 7}}$ Em outra passagem, afirma: "porque, embora a beleza esteja recôndita na proporção, esta proporção é diferente, por isso a natureza varia não menos nas estaturas dos homens do que nas efígies e nos corpos. Pelo qual se vêm alguns grandes, outros pequenos, outros medianos, outros carnosos, outros magros, outros delicados, outros musculosos e robustos". 208 Apesar de relatar a anedota de Zêuxis e destacar a importância de se representar na pintura uma beleza feminina perfeita, remetendo-se para isso à descrição que Ariosto faz de sua fada Alcina, no Orlando Furioso, ${ }^{209}$ a discussão sobre a beleza tem o objetivo primeiro em seu tratado de defender a figuração clássica de Rafael em detrimento às figuras grotescas pintadas por Michelangelo no Juízo Final. O cotejo entre os dois pintores e a defesa que Dolce realiza de Rafael pela voz de Aretino espalha-se em várias passagens do texto, e em referência à diversas partes de composição da pintura, seja no tocante ao movimento das figuras, à representação dos nus, à descrição dos semblantes.

Nos dois tratados o conceito de beleza feminina adquire outras acepções que são, sob certos aspectos, sinônimos com pouquíssimas diferenças de tonalidades. Assim, ao longo da argumentação, beleza é definida ora como vaghezza, enquanto venustà ou então grazia. Pino associa beleza ao termo vaghezza, venustà e grazia. Ao tratar das cores, Pino afirma que vaghezza é o condimento da pintura, relacionando-a ao resultado que deve ser obtido com a cor dos pigmentos. Ele afirma:

“É louvável que o pintor seja vago, a fim de que realize em todas as figuras as maçãs do rosto rosadas e cabelos louros, o ar sereno, a terra toda vestida de um belo verde; mas a verdadeira vaghezza não é outra coisa senão a venustidade ou graça, a qual gera-se por uma convenção ou então justa

\footnotetext{
${ }^{207}$ DOLCE, Lodovico, op. cit., p. 155: “[...] percioché, non procedendo la bellezza da altro, che da una convenevole proporzione che comunemente ha il corpo humano, e particolarmente tra sé ogni membro, et il contrario derivando da sproporzione [...]".Cf. Anexo, p. 104.

${ }^{208}$ DOLCE, Lodovico, op. cit., p. 174: "[...] quantunque la bellezza sia riposta nella proporzione, questa proporzione è diversa, percioché la natura varia non meno nelle stature degli uomini che nelle effigie e nei corpi. Onde alcuni se ne veggono grandi, altri piccioli, altri mezzani, altri carnosi, altri magri, altri delicati, altri muscolosi e robusti”. Cf. Anexo, p. 121.

${ }^{209}$ DOLCE, Lodovico, op. cit., p. 172: "Ma se vogliono i pittori senza fatica trovare um perfetto esempio de bella donna, leggano quelle stanze dell'Ariosto, nelle quali egli discrive mirabilmente le bellezze della fata Alcina, e vedranno parimente quanto i buoni poeti siano ancora essi pittori”. Cf. Anexo, p. 119.
} 
proporção das coisas, tal que, como as pinturas têm do próprio, têm também do vago e honram o mestre". 210

Segundo Luigi Grassi, o termo vaghezza refere-se a "uma beleza delicada, encantadora e artificiosa". ${ }^{211}$ Venustà, ${ }^{\mathbf{2 1 2}}$ apresenta o significado de "uma beleza também encantadora unida à graça e à elegância". ${ }^{213}$ E grazia, apesar de Pino defini-la como sinônimo dos outros termos, nas palavras de Grassi, “é uma propriedade inata ou adquirida, seja inerente ao corpo humano, seja concernente às partes em relação ao todo, quanto ao ritmo da composição, ou às cores [...]". ${ }^{214}$

Grazia, no contexto em que Pino a insere, vincula-se muito mais ao pensamento aristotélico, por conectar-se à justa proporção das partes com o todo das figuras, do que ao sentido que o termo abarca no pensamento platônico, quer seja, "virtude espiritual" ou "luz divina", a ser expressa na fisionomia ou movimento das figuras representadas pelo artífice. Em Alberti, beleza é associada também à vaghezza e à grazia, e todas estão relacionadas à proporção das figuras. $^{215}$

Em Dolce, a beleza ora é grazia, ora venustà. Ou então ele a associa ao termo sprezzatura, em detrimento à affetazione e à facilidade de concepção da obra. Não há uma definição precisa sobre o termo grazia nos diálogos de Dolce. Ao tratar da delicadeza e

\footnotetext{
${ }^{210}$ PINO, Paolo, op. cit., p. 18: “[...] dicovi, che la vaghezza è il condimento dell'opere nostre, non però intendo vaghezza l'azzurro oltra marino da sessanta scudi l'oncia, ò la bella lacha, per ch'i colori sono ancho belli nelle scatole da se stessi, ne è lodabili il pittor,come vago per far à tutte le figure le guancie rosate e capegli biondi, l'aria serena, la terra tutta vestita d'un bel verde, ma la vera vaghezza non è altro, che venustà o grazia, la qual si genera da uma contione, over giusta proportione delle cose, tal che, come le pitture hanno del próprio, hanno ancho del vago e honorano il maestro". Cf. Anexo, p. 5657.

${ }^{211}$ GRASSI, Luigi e PEPE, Mario, op. cit., p. 1031.

${ }^{212}$ Pino cita novamente o termo, mas com relação aos vários ornamentos que a composição deve apresentar. PINO, Paolo., op. cit., p. 16: "[...] che la dechiaratione del soggeto s'includi in poche figure, ornando con varie spoglie, panni, legami, nodi, freggi, veli, armature e altri ornamenti di capo bizarri, e gai, dando all'opere tal venustà e gravita, che rendino li riguardanti ammirativi [...]". Cf. Anexo, p. 52.

${ }^{213}$ GRASSI, Luigi e PEPE, Mario, op. cit., p. 1044.

${ }^{214}$ Idem, ibidem, p. 372. Grassi afirma também que grazia abrange também os significados de leggiadria, e delicatezza, inseridos no conceito de beleza. É um termo de grande importância na literatura, teoria e crítica de arte. Segundo ele, no geral os escritores de arte distinguem beleza da graça, no sentido em que esta última representa um aspecto espiritual e misterioso do homem ou de uma obra, à qual se pode relacionar com aquilo que consideramos como feio.

${ }^{215}$ ALBERTI, Leon Battista, op. cit., p. 106-107: “[...] porrà mente il grembo e chi siede, porra mente quanto dolce le gambe ad chi segga sieno pendenti, noterà di chi stia dritto tutto il corpo né sarà ivi parte alcuna della quale non sappi suo officio et sua misura. Et di tutte le parti li piacerà non solo renderne similitudine ma più aggiugniervi bellezza, però che nella pittura la vaghezza non meno è grata che richiesta".
} 
elegância dos nus de Rafael em sua variedade de movimentos, ele menciona o termo venustà que, sob determinado aspecto, é em suas palavras "um não sei quê, que tanto costuma agradar, tanto nos pintores quanto nos poetas, em guisa de que torne pleno o ânimo de outrem de infinito deleite, não sabendo de qual parte derive aquilo que a nós tanto agrada". ${ }^{216}$ Esse "não sei quê", denominado venustà, Dolce a coliga aos que os antigos Gregos denominavam de charis, ou grazia. ${ }^{217}$

De maneira muito sutil, poderíamos afirmar que, a despeito de uma não definição precisa do termo graça, pelas palavras de Dolce, ela se aproxima (como visto acima ao falarmos de Ficino), do conceito platônico de beleza espiritual que se traduziria nas figuras representadas pelos pintores por meio de uma leveza, elegância e graciosidade de movimentos do corpo, em sua plena harmonia de proporções e conveniência de cores coligada à delicada aparência do semblante. Relação que estabelece Pietro Bembo em seu conceito de beleza. ${ }^{218}$

Quanto ao termo sprezzatura, foi cunhado por Castiglione no Cortesão que também o vinculou ao conceito da graça. Define-se em sua obra enquanto prescrição ao comportamento do cortesão no ambiente da corte. Trata-se de uma conduta refinada que deve desenvolver o cortesão no convívio junto a seus pares. Segundo Castiglione, para tanto, ele deve ater-se à naturalidade de gestos, modos e palavras, e demonstrar fazê-lo sem esforço, a fỉm de evitar toda a qualquer afetação, com uma certa displicência. ${ }^{\mathbf{2 1 9}} \mathrm{O}$ conceito

\footnotetext{
${ }^{216}$ DOLCE, Lodovico, op. cit., p. 195: "Ma non per questo Rafaello è sempre rimaso su la delicatezza [...]. Ma non s'invaghi molto di questa maniera, a guisa di quello che aveva posto ogni suo intento, come parte principalissima del pittore, in dilettare, ricercando più tosto nome di leggiadro che di terribile, e ne acquistò insieme un altro, ché fu chiamato grazioso; percioché, oltre la invenzione, oltre al disegno, oltre alla varietà, oltre che le sue cose tutte movono sommamente, si trova in loro quella parte che avevano, come scrive Plinio, le figure di Apelle, e questa è la venustà, che è quel non so che, che tanto suole aggradire, così ne'pittori come ne'poeti, in guisa che empie l'animo altrui d'infinito diletto, non sapendo da qual parte esca quello che a noi tanto piace". Cf. Anexo, p. 140.

${ }^{217}$ Idem, ibidem, p. 196: "Questa, che voi dite venustà, è detta da' Greci charis, che io esporrei sempre per "grazia". Cf. Anexo, p. 141.

${ }^{218}$ GARIN, Eugenio, op. cit., p. 139: No terceiro livro dos Asolani, Bembo diz: "la bellezza attraverso il concetto stesso di grazia: "ella non è altro che uma grazia, che di proporzione e di convenienza nasce, e d'harmonia nelle cose, la quale quanto è più perfetta ne' suoi suggetti, tanto più amabili essere ce gli fa, e più vaghi: ed è accidente negli uomini non meno dell'animo che del corpo. Perciocché, siccome è bello quel corpo, le cui membra tengono proporzione fra loro, così è bello quell'animo, le cui virtù fanno tra sé harmonia; e tanto più sono di bellezza partecipi l'uno e l'altro, quanto è in loro quella grazia, que io dico, delle loro parti e della loro convenienza più compiuta e più piena."

${ }^{219}$ CASTIGLIONE, Baldassare, op. cit., p. 42: "Mas, tendo eu várias vezes pensado de onde vem essa graça, deixando de lado aqueles que nos astros encontraram uma regra universal, a qual me parece valer, quanto a isso, em todas as coisas humanas que se façam ou se digam mais que qualquer outra, a saber: evitar ao máximo, e como um áspero e perigoso escolho, a afetação; e, talvez para dizer uma palavra nova, usar em
} 
foi aplicado por Dolce à pintura em termos cromáticos, no sentido de expressar uma maneira pictórica em que transpareça uma naturalidade de representação, ${ }^{\mathbf{2 2 0}}$ em que a aparência das figuras transpareça natural e não tão polida ou artificiosa, de forma que, por mais dificuldade que o pintor tenha em alcançá-la, deve demonstrar que a tenha obtido com muita facilidade. $^{221}$

Propusemos demonstrar neste capítulo que, apesar de utilizarem categorias tanto platônicas como aristotélicas, o conceito de um ideal de beleza, tanto para Pino quanto para Dolce (cujos primórdios de argumentação remontam à teoria das Idéias de Platão), aproxima-se e fixa-se muito mais nas relações naturalísticas de proporção e harmonia, retomadas de Aristóteles, do que de um conceito de beleza metafísico e além do mundo natural.

$$
* * *
$$

cada coisa uma certa sprezzatura [displicência] que oculte a arte e demonstre que o que se faz e diz é feito sem esforço e quase sem pensar. É disso, creio eu, que deriva em boa parte a graça, pois das coisas raras e bem feitas cada um sabe as dificuldades, por isso nelas a facilidade provoca grande maravilha; e, ao contrário, esforçar-se, ou, como se diz, arrepelar-se, produz suma falta de graça e faz apreciar pouco qualquer coisa, por maior que ela seja. Porém, pode-se dizer que é arte verdadeira aquela que não pareça ser arte; e em outra coisa não há que se esforçar, senão em escondê-la, porque, se é descoberta, perde todo o crédito e torna o homem pouco estimado".

${ }^{220}$ DOLCE, Lodovico, op, cit., p. 185: "In questo mi pare che ci si voglia una certa convenevole sprezzatura, in modo che non ci sia né troppa vaghezza di colorito, né troppa politezza di figure, ma si vegga nel tutto una amabile sodezza. Percioché sono alcuni pittori che fanno le lor figure sì fattamente pulite che paiono sbellettate, con acconciature di capegli ordinati com tanto studio che pur uno non esce dell'ordine; il che è vizio e non virtù, perchè si cade nell'affettazione, che priva di grazia qualunque cosa". Cf. Anexo, p. 131.

${ }^{221}$ Idem, ibidem, p. 149: "So io bene che in Roma, mentre che Rafaello viveva, la maggior parte, sì de'letterati come de'periti dell'arte, lo anteponevano nella pittura a Michelagnolo. E quelli che inchinavano a Michelagnolo erano per lo più scultori, i quali si fermavano solamente sul disegno e su la terribilità delle sue figure, parendo loro che la maniera leggiadra e gentile di Rafaello fosse troppo facile, e per conseguente non di tanto artifício; non sapendo che la facilita è il principale argomento della eccellenza di qualunque arte e la più difficile a conseguire, et è arte a nasconder l'arte, e che finalmente, oltre al disegno, al pittore richieggono altre parti, tutte necessarissime". Cf. Anexo, p. 100. 


\section{Capítulo V}

\section{A disputa pela primazia da cor sobre o desenho}

Dos primórdios do Renascimento ou, mais precisamente, das últimas décadas do século XIV até cerca da metade do século XVI, a cor foi considerada elemento secundário na pintura, permanecendo vinculada ao claro-escuro e subordinada à hegemonia do desenho. De Cennino Cennini a Alberti e Leonardo, a cor assumiu papel complementar em relação à parte principal da composição, o desenho. No XVI inicia-se uma reivindicação pela valorização da cor, na medida em que teóricos de Veneza rivalizam com aqueles de Florença e Roma. Porém, sua plena valoração terá lugar somente em finais do século XVII quando acadêmicos franceses com a intenção de investigar qual a parte essencial da arte de pintar, confrontarão os dois elementos colocando-os em campos opostos e estabelecendo uma disputa acirrada entre os adeptos do desenho e os partidários da cor.

Em seu Libro dell'Arte, de cerca de 1390, ainda um receituário de oficina com pouquíssimo conteúdo teórico, Cennino Cennini afirma que o fundamento e o princípio da arte e de todos os trabalhos manuais são o desenho e o colorir. Sem maiores digressões sobre os dois termos, Cennini os menciona ao elencar uma série de verbos que definem a atividade mecânica do pintor na preparação dos materiais próprios ao ofício. ${ }^{1}$

Alberti, em Da Pintura, divide a pintura em três partes: circunscrição, composição e recepção de luzes. As duas primeiras tratam do desenho. A discussão sobre a cor está espalhada pelo texto, permanecendo em segundo plano e dependente das questões de luz e sombra. No Trattato della Pittura, de Leonardo, a cor recebe tratamento semelhante ao exposto por Alberti. Está subordinada ao desenho e vem a ser discutida quando da argumentação sobre luz e sombra e perspectiva. É somente no século XVI, com os tratados de Pino e Dolce, e posteriormente com Lomazzo, que tomam respectivamente a posição da escola veneziana e lombarda, defendendo a cor como parte mais importante da pintura, em

\footnotetext{
${ }^{1}$ CENNINO, Cennini. Il Libro dell' Arte. Edizione riveduta e corretta sui codici per cura di Renzo Simi. Lanciano R. Carabba Editore, 1933, Cap. IV Come ti dimostra la regola in quante parti e membri s'appartengon l'arti, p. 19-20: "El fondamento dell'arte, e di tutti questi lavorii di mano il principio, è il disegno e il colorire. Queste due parti vogliono questo,, cioè: sapere tritare, o ver macinare, inconlare, impannare, ingessare, radere i gessi e pulirli, rilevare di gesso, mettere di bolo [...]. A lavorare in muro, bisogna bagnare, smaltare, fregiare, pulire, disegnare, colorire in fresco, trarre a fine in secco, temperare, adornare, finire in muro $[\ldots]$ ".
} 
detrimento à exatidão do desenho. Só então é que a cor passa a contrabalançar a primazia do desenho constante nas teorias Tosco-Romanas. Segundo Jacqueline Lichtenstein, “a cor (para Dolce e Lomazzo) é o que torna os objetos como que dotados de alma e de vida, é ela que permite pintar a carne, representar o movimento, criar a ilusão do vivo; é ela enfim, que está na origem do prazer que o espectador sente diante de um quadro".2

Pelo teor dos escritos de Pino e Dolce, a cor não se insubordina ao desenho, apenas clama por maior espaço na pintura, demonstrando ser capaz de atribuir com seus aspectos cromáticos profunda eloqüência à composição. Se no tratado de Pino encontramos uma tímida valorização da cor, em Dolce a contenda entre os dois elementos torna-se mais significativa, pois sem tecer críticas diretas ao desenho, ele toma o caminho de exaltar a cor de Ticiano em detrimento aos escorços exacerbados de Michelangelo.

A referência à problemática da cor decorre da argumentação da partição que ambos os tratadistas fazem da pintura. Através de uma defesa da importância dos elementos cromáticos na composição, Pino e Dolce tomam uma posição um tanto dissonante em relação aos pressupostos da região Tosco-romana e ante a primazia do desenho enquanto elemento primordial da pintura.

Como mencionado no capítulo II, os dois teóricos seccionam a pintura em desenho, invenção e colorido. Desenho no diálogo de Pino compõe-se de quatro outras partes: juízo, circunscrição, prática e composição. E o colorido apresenta três momentos inerentes à prática do pintor. Primeiro, no discernimento das propriedades das cores e na compreensão de suas composições, a fim de que através delas ele possa reproduzir na pintura a semelhança das características específicas de cada elemento da natureza. Segundo, na prestreza e segurança da mão ao pintar. Terceiro e último, o saber expressar a luz, que na opinião de Pino representa a alma do colorir.

Com relação às quatro seções introduzidas por Pino ao desenho, Luigi Grassi observa que ele criou uma formulação que expõe sua intenção de circunscrever ao redor do desenho todos os momentos que abarcam a experiência pictórica. ${ }^{3}$ Nesse sentido, mesmo pontuando a importância do valor cromático na obra, Pino classifica o desenho enquanto

\footnotetext{
${ }^{2}$ LICHTENSTEIN, Jacqueline. A Pintura - Textos Essenciais. Vol. 9: O Desenho e a Cor. São Paulo, Editora 34, 2006, p. 11.

${ }^{3}$ GRASSI, Luigi. op. cit., p. 187-188: "Ma qui interessa rilevare che il Pino, suddividendo a sua volta il disegno in quattro parti (giudicio, circuscrittione, pratica, retta composizione), fornisce del disegno medesimo una formulazione che denuncia la intenzione di risolvere in esso l'esperienza pittorica".
} 
elemento de maior relevância da pintura, porque é por meio dele que se estabelece toda a estrutura da obra, além do que, o desenho é que deve ser absorvido pela cor, de modo a resultar ao mesmo tempo em imagem colorida e claros-escuros. ${ }^{4}$

Em concordância com as palavras de Luigi Grassi, observamos que de fato Pino atribui relevância ao desenho não somente pelas seções em que ele o divide, como também por considerá-lo o projeto inicial de qualquer arte, como atestado pela seguinte declaração:

"A pintura é a mais alta invenção que se opera entre os homens e todas as artes mecânicas são denominadas artes por participação como membros dependentes dela, pois a pintura representa a natureza das artes mecânicas devido ao desenho, uma vez que os fabros, ditos artífices, não podem sequer formar uma concha de sopa sem fazer uso do desenho". 5

Do mesmo modo em outra passagem ao tratar da comparação entre pintura e escultura, ele pontua: "[...] nem pode o estatuário operar coisa alguma, se quiser fazê-lo em sua arte sem o intermédio do desenho, que é o corpo de nossa arte". 6

Porém, a despeito destas declarações, Pino igualmente não deixa de fazer uma defesa, até mesmo com certa ênfase do valor cromático na pintura, uma vez que, em suas palavras, a cor é importante por permitir ao pintor representar os elementos da natureza em toda sua similitude e propriedades pertinentes, como pintar o tom das peles correspondentes a cada idade, compleição física e grau hierárquico dos personagens; saber distinguir um tecido de linho, de outro de lã ou de seda, saber discernir o ouro do cobre, o ferro da prata, ou então imitar o fogo, figurar a água e o ar, e ainda pintar a variedade de vestimentas com todos os seus ornamentos. ${ }^{7}$ Tais especificidades de representação as quais só podem ser

\footnotetext{
${ }^{4}$ Idem, ibidem, p. 188: "In altri termini, il disegno è assorbito dal colore, il disegno è insieme immagine colorata e chiaroscurale".

${ }^{5}$ PINO, Paolo, op. cit., p. 10: “[...] tutte l'arti mecaniche sono dette arti per participatione, come membri dependenti dalla pittura, la qual è natura dell'arti mecaniche per lo disegno, ch'i fabri, artefici non puono formar pur um minestro senza il disegno [...]". Cf. Anexo p. 29.

${ }^{6}$ Idem, ibidem, p. 26: "“...] né può il statuario operare senza il meggio del disegno, il qual è corpo dell'arte nostra". Cf. Anexo, p. 78.

${ }^{7}$ Idem, ibidem, p. 17: "(Il colorire consiste) in redurre (la pittura) alla similitudine delle cose propie come il variar delle carni corrispondenti all'età, alla complessione e al grado di quel, che si fingere, distinguere um panno di lino da quel di lana, o di seta, far discernere l'oro dal rame, il ferro lúcido dall'argento, imitar ben il fuoco (il che tengo per difficile), distinguere l'acque dall'aere, et avvertire sopra il tutto d'unire e accompagnare la diversità delle tinte in um corpo solo, che così appari nel vivo, di modo che le non habbino
} 
obtidas através do colorido, pois o limite do desenho não lhe permite alcançar semelhante resultado. Assim, somente a cor é capaz de traduzir os elementos naturais com maior eficácia de expressão.

Pino afirma igualmente que infinitas são as características pertencentes ao colorir sendo impossível explicá-las com palavras, uma vez que toda cor, ou por si, ou composta, pode criar os mais diversos efeitos; porém, nenhuma delas apesar de todas as propriedades que lhe são pertinentes consegue alcançar o mínimo de efeitos presentes na natureza, algo que só a inteligência e a prática de bom mestre pode realizar. ${ }^{8}$ A cor é algo tão familiar às pessoas que até mesmo aqueles que as vendem têm conhecimento de suas qualidades, tanto minerais como artificiais, sabendo inclusive como utilizá-las numa obra pictórica. ${ }^{9}$

Em outra passagem, Pino afirma que a graça é o condimento das obras pictóricas e as cores, responsáveis por conferir essa qualidade à pintura são belas até por si mesmas, dentro de seus próprios recipientes. É somente através da cor enquanto ferramenta compositiva que o pintor encontra as inúmeras possibilidades de representar a figura humana em todas os seus aspectos específicos, como pintar de maneira graciosa as maças do rosto feminino, os cabelos louros, a fisionomia serena, ou então figurar paisagens em tão diversas tonalidades verdejantes. ${ }^{\mathbf{1 0}}$

É com respeito à paisagem que Pino constrói uma das observações mais peculiares do tratado. Ele qualifica o colorismo paisagístico veneziano como herdeiro de uma tradição que vinha se desenvolvendo desde Giorgione, a fim de exaltá-lo em relação à produção dos flamengos. Isso se dá quando ele prescreve ao pintor que seja virtuoso no figurar lugares longínquos, pois nessa parte da composição, os flamengos são muito dotados por conseguirem expressar com graciosidade os aspectos selvagens das regiões que habitam.

del rimesso, che non dividano e tagliano uma dal'altra, et ancho da fuggire il profilare cosa gratiosa, e ornar la varietà degli habiti, com freggi differenti, riccami, stratagli, franze, profili e gemme, com altre leggiadre inventioni, dico, nelle fimbrie tanto". Cf. Anexo, p. 53-54.

${ }^{8}$ Idem, ibidem, p. 17: "Sono infinite le cose appertinenti al colorire e impossibile è isplicarle con parole, perché ciascun colore ò da sé, ò composito può far più effetti e niun colore vale per sua propietà à fare un minimo dell'effetti del naturale, però se gli conviene l'intelligentia e pratica de buon maestro[...]". Cf. Anexo, p. 54.

${ }_{9}^{9}$ Idem, ibidem: “[...] non m'istenderò altrimenti nella specie e proprietà dei colori, essendo cosa tanto chiara appresso ognuno, che insino quelli che li vendono, sanno il modo di porli in opera, e conoscono le qualità dei tutti, si minerali, come artificiali [...]". Cf. Anexo, p. 54.

${ }^{10}$ Idem, ibidem, p. 18: “[...] la vaghezza è il condimento dell'opere nostre, non però intendo vaghezza l'azzurro oltra marino da sessanta scudi l'ontia, ò la bella lacha, perch'i colori sono ancho belli nelle scatole da sé stessi, né è lodabile il pittor, come vago per far à tutte le figure le guancie rosate e capegli biondi, l'aria serena, la terra tutta vestita d'un bel verde [...]". Cf. Anexo, p. 56. 
Porém, ele defende que a Itália é o jardim do mundo e suas paisagens causam enorme deleite ao serem contempladas, o que provam as belíssimas e engenhosas paisagens de Ticiano e de Savoldo, pois a descrição que ambos fazem do natural supera a representação flamenga. $^{11}$

Entre os pintores virtuosos que Pino elenca em seu tratado, Bronzino ganha destaque, pois em suas palavras irá se tornar grande mestre por ser excelente colorista. ${ }^{\mathbf{1 2}}$ Porém, os dois pintores mais conceituados pelos quais ele nutre profunda admiração são Michelangelo e Ticiano. Escreve Pino:

"Devido à sua virtude desfrutam três vidas, uma natural, a outra artificial e a outra eterna. São homens bem afortunados vistos por poucos e celebrados por todos, eleitos por Deus, favoritos pelos fados, bem criados pela natureza e pelos filhos abraçados por aquela arte, que foi descoberta e usada por Deus, eterno pintor. E tais homens por conseqüência de suas virtudes fazem-se dignos de serem denominados deuses mortais". ${ }^{13}$

De todos os trechos em que Pino discute a cor, o momento emblemático de seu diálogo toma lugar quando, em sua tentativa de exaltar o colorido, Pino o equipara ao desenho, ao afirmar que em sua opinião Michelangelo e Ticiano são verdadeiros deuses e

\footnotetext{
${ }^{11}$ Idem, ibidem, p. 29: “[...] e dietro a ciò ami grandemente il farsi pratico e valente nelli lontani, d'il che ne sono molto dotati gli oltramontani e queste avviene perché fingono i paesi habitati da loro, i quali per quella loro selvatichezza si rendono gratissimi, ma noi italiani siamo nel giardino del mondo, cosa più dilettevole da vedere, che da fingere, pur io ho veduto di mano de Titiano paesi miracolosi e molto più gratiosi che li Fiandresi non sono. Messer Gierolamo Bresciano in questa parte era dottissimo, della cui mano vidi già alcune aurore com rifletti del sole, certe oscurità con mille discrittioni ingeniosissime e rare, le qual cose hanno più vera imagine del próprio, che li Fiamenghi". Cf. Anexo, p. 86.

${ }^{12}$ Idem, ibidem, p. 24: “[...] ma se Bronzino seguita all'ascendere, egli verrà un'eccellentissimo maestro, e ardisco, ch'egli mi pare il più bel coloritore che dipinga à giorni nostri". "Bronzino è un perito maestro e mi piace molto il suo fare e li sono ancho partial per le virtù [...]". Cf. Anexo, p. 75.

${ }^{13}$ Idem, ibidem, p. 23: "[...] e qual gioggia pensate voi, che sai di Michiel Angelo Buonarroti, di Titiano e altri, che per le loro virtù fruiscono ter vite, l'una naturale, l'altra artificiale, et l'altra eterna? Ó ben fortunati huomini veduti da pochi e celebrati da tutti, eletti da Iddio, favoriti da i fati, ben creati dalla natura e per figliuoli abbracciati dall'arte e da qual arte? Da quella ritrovata e usata dall'eterno pittore Iddio nostro. Ó felici e gloriosi spiriti celebri al mondo con tal virtù, che vi fà degni d'esser nominati Dei mortali". Cf. Anexo, p. 71.
} 
líderes dos pintores, ${ }^{14}$ e se fosse possível unir o desenho de Michelangelo à cor de Ticiano, poder-se-ia assim criar o deus da pintura. ${ }^{15}$

Talvez o grande mérito de Pino tenha sido tentar, ainda na metade do século XVI, estabelecer uma equivalência de valor entre desenho e cor, ao colocar num mesmo nível de importância, Michelangelo e Ticiano. Mas é com Dolce que essa reivindicação tornar-se-á mais veemente.

Conforme Rodolfo e Anna Pallucchini, dentro de um esquema cultural renascentista influenciado por Alberti, Pino desenvolve seus argumentos em prol de uma qualificação dos valores pictóricos de tradição veneta. Ele parte de um ponto de vista ainda ancorado na influência de Giorgione via Savoldo, apesar de não deixar de se voltar às novas tendências expressas pelo claro-escuro dramático e estruturas movimentadas, que viam em Tintoretto e Schiavone naquele momento seus maiores representantes. ${ }^{\mathbf{1 6}}$

As observações sobre a cor pontuadas em seu tratado denotam uma sensibilidade e um refinamento de análise que faltavam a outras tradições. A propriedade no distinguir as cores revela um gosto sutil de Pino na discriminação dos valores pictóricos, o que demonstra um apego à herança de seu mestre Savoldo. ${ }^{17}$

O Dialogo di Pittura é a tentativa de um pintor vêneto, ainda que mediano, porém letrado, de discutir as problemáticas da arte de seu período, como também de defender a expressão pictórica veneziana, que se subleva de maneira tímida ante a imponência da arte da Itália central, reivindicando para si um mesmo espaço de valor e apreciação. E nesse sentido o colorido eleva-se a uma posição superior por ser equiparado ao desenho.

O tema principal do Dialogo della Pittura, de Lodovico Dolce, é a comparação entre o virtuosismo do desenho de Michelangelo, o classicismo de Rafael e o engenho do

\footnotetext{
${ }^{14}$ Idem, ibidem, p. 24: "Non vi pongo Michiel Angelo, né Titiano, perché questi duo li tengo come Dei e come capi dei pittori, e questo lo dico veramente senza passione alcuna". Cf. Anexo, p. 74.

${ }^{15}$ Idem, ibidem: "[...] et se Titiano e Michiel Ângelo fussero um corpo solo, over al disegno di Michiel Ângelo aggiontovi il colore di Titiano, se gli potrebbe dir lo dio della pittura [...]". Cf. Anexo, p. 75.

${ }^{16}$ PALLUCCHINI, Rodolfo ed Anna Pallucchini, op. cit., p. 27: "Dentro schemi di cultura rinascimentale, precisamente albertiana, il Pino mette a fuoco il suo pensiero, indirizzandolo verso una qualificazione dei valori della tradizione veneta; partendo da un punto di vista ancora neogiorgionesco, nei limiti della sua educazione savoldiana, egli fraintende i nuovi atteggiamenti di chiaroscuro drammatico e di movimentate strutture, che, nell'anno in cui scrive, avevano nel Tintoretto e nello Schiavone i massimi assertori".

${ }^{17}$ Idem, ibidem, p. 40, 41: "Gli accenni dedicati dal Pino al colore denotano una sensibilità, anzi una raffinatezza, che mancava ad altre tradizioni. La proprietà del distinguer i colori, come è già stato acutamente osservato dalla Nicco Fasola [...] denuncia un gusto sottile nella discriminazione dei valori pittorici, che non può non rammentare la lezione del Savoldo, di cui il Pino si dichiara scolaro".
} 
colorido de Ticiano, culminando na conclusão da superioridade do veneziano em relação aos outros dois mestres. Na argumentação do tratado, ao invés de traçar a defesa da cor frente ao desenho de maneira explícita, Dolce contrapõe o colorido de Ticiano ao desenho de Michelangelo, qualificando a supremacia do veneziano em detrimento ao florentino.

A princípio, Dolce, sob a influência da divindade conferida a Michelangelo por Vasari em suas Vite, ${ }^{\mathbf{1 8}}$ reconhece a grandiosidade de seu desenho ao pontuar que ele tem sido um dos primeiros pintores do século XVI a demonstrar com profunda habilidade as belas linhas de contorno, os escorços, o relevo e a mecânica de movimento, as quais são características fundamentais para uma perfeita representação das figuras desnudas. ${ }^{19} \mathrm{Na}$ medida em que a argumentação de sua tese avança pelo tratado, Dolce passa a fazer intensas críticas a Michelangelo.

Quanto a Rafael, igualmente com base em Vasari, ${ }^{\mathbf{2 0}}$ ou muito mais influenciado pela apologia feita a ele por Pietro Bembo, nivelando-o a Michelangelo e a excelência de ambos

\footnotetext{
${ }^{18}$ Apud VASARI, Giorgio, T, pp. 560 s., citado por BAROCCHI, Paola, Trattati D'Arte del Cinquecento. op. cit., p. 436, nota 4 da p. 146: "Ma quello che fra i morti e i vivi porta la palma e trascende et ricuopre tutte è il divin Michelagnolo Buonarroti; il qual non solo tien il principato di una di queste arti, ma di tutte tre insieme. Costui supera e vince non solamente tutti costoro che hanno quasi che vinto già la natura, ma quelli stessi famosissimi antichi che sì lodatamente fuor d'ogni dubbio la superarono. Et unico giustamente si trionfa di quegli,di questi e di lei: non imaginandosi appena, quella, cosa alcuna sì strana e tanto difficile che egli con la virtù del divinissimo ingegno suo, mediante la industria, il disegno, l'arte, il giudizio e la grazia, di gran lunga non la trapassi. E non solo nella pittura e ne'colori, sotto il qual genere si comprendono tutte le forme e tutti i corpi retti et non retti, palpabili e impalpabili, visibili e non visibili, ma nella estrema rotonditade ancora de'corpi, e con la punta del suo scarpello ... Ben si può dire e sicuramente le sue statue ... esser più belle assai che le antiche, conoscendosi, nel mettere a paragone teste, mani, braccia e piedi formati da l'uno e da l'altro, rimanere in quelle di costui un certo fondamento più saldo, una grazia più interamente graziosa et una molto più assoluta perfezzione, condotta con una certa difficultà sì facile nella sua maniera, che egli è impossibile mai veder meglio. Il che medesimamente per conseguenzia si può credere de le sue pitture; le quali, se per adventura ci fussero di quelle famosissime greche o romane da poterle a fronte a fronte paragonare, tanto resterebbono pregio e più onorate, quanto più appariscono le sue sculture superiori a tutte le antiche".

${ }^{19}$ DOLCE, Lodovico, op. cit., p. 146: "Non vi niego che Michelagnolo a' nostri dì non sai un raro miracolo dell'arte e della natura. E quelli che non ammirano le cose sue non hanno punto di giudicio, e massimamente d'intorno alla parte del disegno, nella quale senza dubbio è profondissimo: percioché egli è stato il primo che in questo secolo ha dimostro a'pittori i bei dintorni, gli scorti, il rilevo, le movenzie e tutto quello che si ricerca in fare un nudo a perfezione [...]". Cf. Anexo, p. 98.

${ }^{20}$ Apud VASARI, Giorgio, T, pp. 559 s., citado por BAROCCHI, Paola, op. cit., p. 438, nota 1 da p. 148: "Aveva acquistado in Roma Rafaello in questi tempi molta fama; et ancora che egli avesse la maniera gentile, da ognuno tenuta belissima, con tutto che egli avesse veduto tante anticaglie in quella città e che egli studiasse continuamente, non aveva però per questo dato ancora alle sue figure una certa grandezza e maestà, che e'diede loro da qui in avanti. Perché avvene in questo tempo che ... avendo Bramante la chiave della cappella (Sistina), a Rafaello, come amico, la fece vedere, acciocché i modi di Michelagnolo comprendere potesse. Onde tal vista fu cagione che in Santo Agostino sopra la Santa Anna di Andrea Sansovino in Roma Rafaello súbito rifece di nuovo lo Esaia profeta che ci si vede; che di già lo aveva finito. La quale opera per le cose vedute di Michelagnolo migliorò et ingrandì fuor di modo la maniera e diedeli più maestà".
} 
à maestria dos artífices antigos, ${ }^{\mathbf{2 1}}$ Dolce enaltece a maneira delicada e elegante de suas figuras confrontando-a à terrível aparência das figuras do florentino representadas no Juízo Final. $^{22}$ De forma semelhante utiliza-se do mesmo procedimento de contraposição entre os dois artífices ao longo do tratado com respeito a diversos aspectos do processo compositivo da pintura.

É, no entanto, a partir de sua discussão sobre as partes da pintura, que Dolce vem a construir o raciocínio em prol do colorido de Ticiano e da pintura veneziana. Seu diálogo propõe a mesma partição já estabelecida por Pino: desenho, invenção e colorido.

Apesar de toda ênfase que Dolce encerra na defesa do colorido, ele não deixa de exaltar em determinado trecho a importância do desenho, através de uma pequena sentença muito similar às palavras de Pino:

"Pode-se dizer que só a mão do pintor seja seu guia e o desenho é próprio ao seu ofício. Há ainda que ser reconhecido pelo pintor que a carta do navegar e igualmente todas as artes manuais, no desenho têm origem e adquirem forma, porque arquitetos, muradores, entalhadores, ourives, recamadores, lenhadores e enfim, os fabros, todos recorrem a ele[...]. Não se pode negar que em qualquer coisa que queira significar ser bela, diz-se nela haver desenho". 23

\footnotetext{
${ }^{21}$ BEMBO, Pietro. Prose della Volgar Lingua. Torino, Unione Tipografico-Editrice Torinese, 1931, p. 79: “e poscia, quando a fare essi alcuna nuova opera intendono, mirano in quegli essempli, e di rassomigliarli col loro artificio procacciando, [gli artefici] tanto più sè dovere essere della loro fatica lodati si credono, quando essi più alle antiche cose fanno per somiglianza ravicinare de loro nuove; perciò che sanno e veggono che quelle antiche più alla perfezion dell'arte s'accostano, che le fatte da indi innanzi. Questo hanno fatto più che altri, Monsignore M. Giulio, i vostri Michele Agnolo Fiorentino e Rafaello da Urbino, l'uno dipintore e scultore e architetto parimente, l'altro e dipintore e architetto altresì; e hannolo sì diligentemente fatto, che ambedue sono ora così eccellenti e così chiari, che più agevole è a dire quanto essi agli antichi buoni maestri sieno prossimanti, che quale di loro sia dell'altro maggiore e miglior maestro".

${ }^{22}$ DOLCE, Lodovico, op. cit., p. 149: “[...] E quelli che inchinavano a Michelagnolo errano per lo più scultori, i quali si fermavano solamente sul disegno e su la terribilità delle sue figure, parendo loro che la maniera leggiadra e gentile di Rafaello fosse troppo facile, e per conseguente non di tanto artificio [...]". Cf. Anexo, p. 100.

${ }^{23}$ Idem, ibidem, p. 162: "[...] può dire che la sola mano del pittore sia lor guida, essendo che il disegno è proprio di esso pittore. Hassi ancora a riconoscer dal pittore la carta del navigare, a parimente da lui hanno origine e forma tutte le arti manuali, perché architetti, muratori, intagliatori, orefici, ricamatori, legnaiuoli et infino i fabbri, tutti ricorrono al disegno, proprio, come s'è detto, del pittore". "Non si può negare: percioché di qualunque cosa, volendo significar che ella sia bella, si dice lei aver disegno”. Cf. Anexo, p. 110.
} 
Já quanto ao colorido muitas são as passagens a ele dedicadas. Assim, primeiramente Dolce o define como sendo "as tintas com as quais a natureza pinta diferentemente as coisas animadas ou inanimadas; animadas como são os homens e os animais irracionais; inanimadas como seixos, ervas e plantas". ${ }^{24}$

A profunda relevância e força do colorido nas palavras de Dolce revela-se na capacidade da cor de expressar as várias tonalidades da pele humana e as propriedades específicas à aparência de qualquer dos elementos da natureza, de modo a fazer com que a pintura pareça ter vida e as personagens serem tão reais a ponto de lhes faltar somente a respiração: "E certamente o colorido é de tão grande importância e força que, quando o pintor imita bem as tintas e a maciez das carnes e a propriedade de qualquer coisa, faz com que suas pinturas pareçam vivas de tal modo, que a elas não falte outra coisa senão a respiração". 25 Imitar a pele em sua maciez é, de acordo com Dolce, uma das maiores dificuldades do colorido. ${ }^{26}$

A essência do colorido reside nos jogos de luz e sombra, através dos quais a competição entre claros e escuros deve resultar em harmonia, a fim de possibilitar a representação das figuras em relevo e em escorço, conforme as normas da perspectiva:

"A principal parte do colorido é a contenda que o lume trava com a sombra, a qual se verifica por intermédio de que um contrário se una com outro e faça com que as figuras pareçam arredondadas, e tanto mais ou tanto menos segundo a necessidade tornem-se distantes devendo o pintor dar-se conta de que, ao colori-las elas não façam confusão. No que é conveniente que ele tenha bom conhecimento de perspectiva para diminuir as coisas fugidias que se fingem longínquas". ${ }^{27}$

\footnotetext{
${ }^{24}$ Idem, ibidem, p. 164: "Il colorito serve a quelle tinte, con le quali la natura dipinge (che così si può dire) diversamente le cose animate e inanimate; animate, come sono gli uomini e gli animali bruti; inanimate, come i sassi, l'erbe, le piante e cose tali [...]". Cf. Anexo, p. 111.

${ }^{25}$ Idem, ibidem, p. 183: "Questo serve alla molta cura che ponevano gli antichi nel colorire, perché le cose loro imitassero il vero. E certo il colorito è di tanta importanza e forza, che, quando il pittore va imitando bene le tinte e la morbidezza delle carni e la proprietà di qualunque cosa, fa parer le sue pinture vive e tali che lor non manchi altro che "l fiato". Cf. Anexo, p. 129.

${ }^{26}$ Idem, ibidem, p. 184: "Così la principal difficultà del colorito è posta nella imitazione delle carni e consiste nella varietà delle tinte e nella morbidezza”. Cf. Anexo, p. 130.

${ }^{27}$ Idem, ibidem, p. 183: "È la principal parte del colorito il contendimento che fa il lume con l'ombra: a che si dà un mezzo, che unisce l'un contrario con l'altro e fa parere le figure tonde, e più e meno, secondo il bisogno, distanti, dovendo il pittore avvertire che, nel collocarle, elle non facciano confusione. In che è di
} 
Urge ao pintor ser habilidoso ao manusear as tintas com o propósito de representar a cor da pele de modo harmonioso, expressando a maciez que lhe é peculiar, pois caso ele não tenha o domínio no trato com as tintas suas figuras parecerão duras e artificiais devido à veemência no uso inadequado de luzes e sombras:

"É necessário ter sempre o olho atento às tintas principalmente das carnes e à sua maciez, pois muitos pintores as figuram como se parecessem de pórfiro, tanto quanto à cor quanto à dureza. As sombras revelam-se fortes demais e não raro terminam em puro negro. Muitos as representam brancas em demasia, outros, demasiado rubras. Eu, por mim, desejarei intensamente uma cor antes escura, do que branca de modo não conveniente e condenarei em minhas pinturas comumente aquelas maçãs do rosto vermelhas com os lábios de coral, porque assim feitos, os semblantes terão a aparência de máscaras". 28

Conforme Dolce, o colorido permite ao pintor fazer a distinção de seus personagens quanto ao sexo, à idade e ao grau hierárquico. Observamos que, quanto aos trechos seguintes, as palavras de Dolce assemelham-se muito ao exposto no tratado de Pino quanto à conveniência (já citado no capítulo II):

"É verdade que se deve variar as tintas e ter consideração aos sexos, às idades e às condições. Pois, no que diz respeito aos sexos, uma cor geralmente convém às carnes de uma jovem e outra a um rapaz; quanto à idade, determinada cor requer a um ancião e outra a um jovem, e no tocante

bisogno parimente di aver buona cognizione di prospettiva, per il diminuir delle cose che sfuggono e si fingono lontane". Cf. Anexo, p. 129.

${ }^{28}$ Idem, ibidem: "Ma bisogna aver sempre l'occhio intento alle tinte, principalmente delle carni, e alla mordidezza, percioché molti ve ne fanno alcune che paiono di porfido, sì nel colore come in durezza, e le ombre sono troppo fiere e le più volte finiscono in puro negro; molti le fanno troppo bianche, molti troppo rosse. Io, per me, bramerei un colore anzi bruno che sconvenevolmente bianco e sbandirei dalle mie pitture comunemente quelle guancie vermiglie con le labbra di corallo, perché così fatti volti paiono mascare". Cf. Anexo, p. 129. 
às condições, não requer a um camponês o que pertence a um gentilhomem". 29

Em outras passagens, o teórico prescreve que as cores devam ser bem unidas e esfumadas de maneira a esconder as linhas de contorno inexistentes na natureza (sutil crítica à linearidade do desenho). Luzes e sombras dispostas de maneira adequada tornam as figuras arredondadas, fazendo-as se destacar em relevo, uma das partes mais importantes do colorido, sem o qual a pintura de fato revela-se ter sido criada numa superfície plana:

“É necessário que a mistura de cores seja esfumada e unida, de modo a representar o natural e não restar coisa alguma que ofenda aos olhos, tais como as linhas de contorno que se deve evitar, pois a natureza não as criou, nem mesmo o negror das sombras vigorosas e desunidas. Estes lumes e sombras dispostos com juízo e arte tornam as figuras arredondadas e atribuem a elas o relevo que se procura. E as figuras que de relevo são destituídas, parecem mal pintadas, uma vez que revela a superfície plana. Quem portanto, conhece esta parte dos relevos, tem uma das mais importantes".30

Outro momento do diálogo em que ele retoma palavras similares àquelas ditas por Pino, encontra-se no trecho a seguir onde ele prescreve ao pintor o saber discernir pelas cores a característica específica de diversos outros elementos da natureza:

"É necessário que o pintor saiba imitar a cor dos tecidos, tais como a seda e o ouro em todas as suas qualidades, a fim de que se possa distinguir a

\footnotetext{
${ }^{29}$ Idem, ibidem, p. 184: "È vero che queste tinte si debbono variare, et aver parimente considerazione ai sessi, alle età et alle condizioni. Ai sessi, ché altro colore generalmente conviene alle carni d'una giovane et altro ancora d'un giovane; all'età, ché altro si richiede a un vecchio et altro pure a un giovane; et alle condizioni, ché non ricerca a un contadino quello che appartiene a un gentiluomo". Cf. Anexo, p. 130.

${ }^{30}$ Idem, ibidem: "Ora, bisogna che la mescolanza de'colori sia sfumada et unita de modo che rappresenti il naturale e non resti cosa che offenda gli occhi, come sono le linee de'contorni, le quali se debbono fuggire, ché la natura non le fa, e la negrezza ch'io dico dell'ombre fiere e disnunite. Questi lumi et ombre, posti con giudicio et arte, fanno tondeggiar le figure e danno loro il rilevo che si ricerca; del qual rilevo le figure che sono prive, paiono, come ben diceste, dipinte, percioché resta la superficie piana. Chi adunque ha questa parte, ne ha una delle più importanti”. Cf. Anexo, p. 130.
} 
aspereza ou a delicadeza, segundo o tipo de tecido. Deve-se saber fingir o lustroso das armas, o fosco da noite, a claridade do dia, relâmpagos, fogos, lumes, água, terra, seixos, ervas, árvores, ramos, flores, frutos, edifícios, casarões, animais. Os elementos devem ser representados com tal plenitude e tão semelhantes ao real de modo a jamais despertarem o enfado aos olhos de quem os contempla. Não se deve acreditar que a força do colorido consista somente na escolha de belas cores, como as belas lacas, os belos azuis, belos verdes e similares, pois elas são belas por si mesmas, sem terem sido colocadas na obra. Sua força porém, reside na habilidade do pintor em saber manejá-las de forma conveniente". 31

Tanto em Pino quanto em Dolce, verifica-se esta profunda distinção entre cor e colorido. Os argumentos expostos destinam-se a provar que a pintura não significa somente o ato mecânico de despejar as cores na tela a partir seus recipientes, pois o colorido não decorre da natureza das cores, "belas por si mesmas", mas resulta da habilidade e talento do pintor em transformá-las em arte, imitando com perfeição por meio delas a tonalidade dos elementos tais quais se encontram na natureza.

Dolce defende também que o pintor deva evitar no uso das cores a extrema artificialidade para não incorrer na afetação, mas representar suas figuras com naturalidade e graça:

"Parece-me que se requeira aqui uma conveniente displicência, de modo a não haver o demasiado garbo do colorido, nem a posição das figuras seja feita com grande polidez, mas que se perceba no todo uma amável solidez. Há pintores que fazem suas figuras de tal maneira polidas que estas parecem ter sido ornadas de modo artificioso, com toucados de cabelos ordenados com tanto estudo que nem um somente sai da ordem; o que é

\footnotetext{
${ }^{31}$ Idem, ibidem: "Bisogna dipoi sapere imitare il color de'panni, la seta, l'oro et ogni qualità, così bene che paia di veder la durezza o la tenerezza più e meno, secondo che alla condizion del panno si conviene; saper fingere il lustro delle armi, il fosco della notte, la chiarezza del giorno, lampi, fuochi, lumi, acqua, terra, sassi, erbe, arbori, frondi, fiori, frutti, edifici, casamenti, animali e sì fatte cose, tanto a pieno che elle abbiano tutte del vivo e non sazino mai gli occhi di chi le mira. Né creda alcuno che la forza del colorito consista nella scelta de' bei colori, come belle lache, bei azzurri, bei verdi e simili; percioché questi colori sono belli parimente senza che e'si mettano in opera, ma nel sapergli maneggiare convenevolmente". Cf. Anexo, p. 130.
} 
vício e não virtude, porque se cai na afetação, que priva de graça qualquer coisa".32

Segundo Jacqueline Lichtenstein, o diálogo de Dolce é um dos primeiros textos a propor os fundamentos de uma doutrina da cor, cujos pressupostos terão grande repercussão e desenvolvimento na França a partir do século XVII. E o ponto alto do tratado encontra-se como mencionado na exposição de trechos acima, na capacidade do pintor de expressar a carnação por meio do colorido. ${ }^{33}$

Com respeito ao cotejo entre os dois primeiros artífices, Rafael e Michelangelo, Dolce afirma que Rafael teve o domínio de todas as partes que compunham a pintura, ${ }^{34}$ seja quanto à invenção, ${ }^{35}$ conveniência, variedade e copiosidade das figuras sacras ou profanas, seja ao representá-las apropriadamente desnudas ou vestidas em seus inúmeros movimentos. Michelangelo, por sua vez, revelou-se ser virtuoso unicamente no desenho, nos escorços e na expressão da dinâmica exarcebada de corpos musculosos, alcançando, neste aspecto, como nenhum outro, a perfeição. ${ }^{\mathbf{3 6}}$ Mas quanto às outras maneiras, de acordo com Dolce ele fica a desejar, pois não sabe observar em suas figuras as diversidades de idade e sexo. Enquanto as figuras de Rafael revelam moderação e delicadeza de gestos, ${ }^{37}$ vindo ao encontro do gosto clássico de Dolce, Michelangelo perde em consideração devido à terribilità e artificialidade de sua figuração. ${ }^{\mathbf{3 8}}$

\footnotetext{
${ }^{32}$ Trecho original já citado no capítulo II.

${ }^{33}$ LICHTENSTEIN, Jacqueline, op, cit., p. 23.

${ }^{34}$ DOLCE, Lodovico, op. cit., p. 187: "Ricercando adunque tutte le parti che si richieggono al pittore, troveremo che Michelagnolo ne possede una sola, che è il disegno, e che Rafaello le possedeva tutte, o almeno (perché l'uomo non può esser Dio, a cui niuna cosa manca) [...]”. Cf. Anexo, p. 133.

35 Idem, ibidem, "[...] troverà Rafaello aver mirabilmente osservato tutto quello che alla invenzione appartiene; e Michelagnolo o niente o poco". Cf. Anexo, p. 133.

${ }^{36}$ Idem, ibidem, p. 193: "Ma d'intorno al disegno, ch'è la seconda parte, dovendo noi considerar l'uomo vestito et ignudo, vi confermo che, quanto al nudo, Michelagnolo è stupendo e veramente miracoloso e sopra umano, né fu alcuno che l'avanzasse giamai; ma in una maniera sola, ch'è in fare un corpo nudo musculoso e ricercato, con iscorti e movimenti fieri, che dimostrano minutamente ogni difficultà dell'arte. Et ogni parte di detto corpo, e tutte insieme, sono di tanta eccellenza, che ardisco dire che non si possa imaginar, non che far, cosa più eccellente né più perfetta”. Cf. Anexo, p. 138.

${ }^{37}$ Idem, ibidem, p. 194: "Io vi dico che Rafaello sapeva far bene ogni sorte di nudi, e Michelagnolo riesce eccellente in uma sola". Cf. Anexo, p. 139.

${ }^{38}$ Idem, ibidem, p. 193: "Ma nelle altre maniere è non solo minore di sé stesso, ma di altri ancora; perché egli o non sa o non vuole osservar quelle diversità delle età e dei sessi che si son dette di sopra, nelle quali è tanto mirabile Rafaello. E per conchiuderla, chi vede um sola figura di Michelagnolo, le vede tutte. Ma è da avvertire che Michelagnolo há preso del nudo la forma più terribile e ricercata, e Rafaello la più piacevole $\mathrm{e}$ graziosa [...]". Cf. Anexo, p. 138.
} 
Se Rafael é na visão de Dolce superior a Michelangelo, Ticiano por sua vez tem a supremacia em relação a ambos:

"[...] Só verdadeiramente em Tiziano (e seja dito com a paz dos outros pintores) vêem-se recolhidas à perfeição todas as partes excelentes que são divididas em muitas, porque nem quanto à invenção nem quanto ao desenho ninguém o superou jamais. E no que se refere ao colorido nunca houve alguém que o tivesse alcançado. Pelo contrário, somente a Tiziano deve-se dar a glória do perfeito colorido, algo que nenhum dos antigos revelou. Nem mesmo qualquer dos modernos, pois caso algum o tenha possuído, faltou a um mais a outro menos; e como eu disse ele caminha a par com a natureza, pois toda sua figura é viva, move-se e as carnes palpitam. Jamais demonstrou Tiziano em suas pinturas uma graciosidade vã, mas propriedade conveniente de cores; nem mesmo ornamentos artificiosos, mas firmeza de mestre; não crueza, porém o macio e tenro da natureza. Em suas pinturas contrastam e agitam-se graciosamente sempre os lumes com as sombras, perdem-se e se diminuem daquele mesmo modo com que faz a idêntica natureza". 39

A terceira e última parte do diálogo é uma apologia tecida por Dolce ao pintor veneziano. Ele delineia um sucinto percurso biográfico no qual relata fatos da ascensão de Ticiano, exaltando-o sempre. Faz também descrições pormenorizadas de algumas obras, relata o aprendizado com os irmãos Bellini e Giorgione, a realização de retábulos para as Igrejas, enfatiza o exímio retratista e o pintor estimado por imperadores, príncipes, reis, duques, papas. Por fim, apesar de afirmar que entre todos os excelentes pintores, os três,

\footnotetext{
${ }^{39}$ Idem, ibidem, p. 200: "[...] percioché in costui solo veramente (e sia detto con pace degli altri pittori) si veggono raccolte a perfezzione tutte le parti eccellenti che si sono trovate divise in molti, essendo che d'invenzione né di disegno niuno lo superò giamai. Poi, di colorido non fu mai alcuno che a lui arrivasse. Anzi, a Tiziano solo si dee dare la gloria del perfetto colorito, la quale o non ebbe alcun degli antichi, o, se l'ebbe, mancò, a chi più a chi manco, in tutti i moderni; percioché, come io dissi, egli camina di pari con la natura, onde ogni sua figura è viva, si muove e le carni tremano. Non ha dimostro Tiziano nelle sue opere vaghezza vana, ma proprietà convenevole di colori, non ornamenti affettati, ma sodezza da maestro, non crudezza, ma il pastoso e tenero della natura; e nelle cose sue combattono e scherzano sempre i lumi com l'ombre, e perdono e diminuiscono con quell'istesso modo che fa la medesima natura". Cf. Anexo, 144-145.
} 
Michelangelo, Rafael e Ticiano obtêm o principado, ${ }^{40}$ é ao último a quem ele confere a divindade, declarando ser Ticiano divino e sem par no que se refere à pintura. ${ }^{41}$

É possível depreender como objetivo primeiro dos tratados de Pino e Dolce, pelo teor das palavras acima expostas, que, além de efetuar uma defesa veemente da arte veneziana, cuja essência residia na exuberância do colorido, eles tiveram como intenção fazer uma réplica aos pressupostos teóricos tosco-romanos que se apresentavam como a única verdade da arte desde o século XV. Sem ter a priori projeto de criar uma teoria artística veneta, eles deram no entanto o passo inicial para lhe estabelecer os fundamentos.

O tratado de Pino pretendeu apenas redargüir ao Da Pintura, de Alberti, nos termos de ressaltar a relevância dos aspectos prático-empíricos do operar a pintura, em detrimento aos preceitos matemático-científicos propostos pelo florentino, como afirmado por suas próprias palavras: "E Leon Battista Alberti, pintor não menor, fez um tratado de pintura em língua latina, que é mais de Matemática do que de pintura, ainda que prometa ao contrário". 42 E Dolce, em instância semelhante, brada contra as Vite de Vasari, em sua primeira edição de 1550, que legitimaram a excelência da pintura de Michelangelo e Rafael, legando quase ao esquecimento a preponderância da arte veneziana, em especial representada pela figura de Ticiano.

Poderíamos afirmar que, principalmente pela ênfase dada por Dolce na argumentação sobre as possibilidades da cor, prefigura-se uma tímida refutação da relevância cromática pictórica por seu apelo sensível, frente ao racionalismo linear do desenho, de forma a atribuir ao colorido a primazia de poder exprimir toda gama de sutilezas e propriedades específicas dos elementos naturais e da figura humana, potência negada à capacidade expressiva do desenho.

O tratado de Dolce, portanto, assinala sutis, porém, importantes divergências entre as potencialidades do desenho e da cor, contenda ilustrada pelo confronto entre Michelangelo e Ticiano. No entanto, é possível estabelecer uma analogia entre eles no que concerne a um determinado procedimento, técnica (ou então característica) que ambos

\footnotetext{
${ }^{40}$ Idem, ibidem, p. 206: "[...] oggidì ci siano stati molti pittori eccellenti, questi tre ottengono il prencipato: cioè Michelagnolo, Rafaello e Tiziano". Cf. Anexo, p. 150.

${ }^{41}$ Idem, ibidem: "È adunque il nostro Tiziano nella pittura divino e senza pari; né si dovrebbe sdegnare l'stesso Apelle, quando e'vivesse, di onorarlo". Cf. Anexo p. 149.

${ }^{42}$ PINO, Paolo, op. cit., p. 3: "[...] e Leon Battista Alberto Fiorentino, pittore non menomo fece un trattato di pittura in lingua latina, il qual è più di Mathematica, che di pittura, anchor che prometti il contrario". Cf. Anexo, p. 3.
} 
expressaram em suas obras dos anos maduros, e mesmo tendo se valido deste processo em diferentes suportes, Ticiano, a tela e Michelangelo, o mármore. Trata-se da noção da perfeição-imperfeição, ou mais precisamente do finito-non-finito. Temática complexa e há tempos muito debatida de modo competente por inúmeros estudiosos, ela será aqui referida unicamente com respeito à posição de Vasari, a fim de que possamos estabelecer um tênue cotejo entre esses dois virtuosos mestres.

O conceito foi prescrito por Vasari enquanto tentativa de apreender a atitude de alguns artífices de não levar a termo suas obras, em particular, a figura de Michelangelo. A princípio duas hipóteses foram levantadas por ele. Primeiro, o non-finito insurgia-se a Vasari como sendo uma espécie de função instrumental, uma técnica de execução ${ }^{\mathbf{4 3}}$ similar ao preceito proposto por Alberti no Della Sculptura, o qual aconselhava ao artífice pintar ou esculpir obedecendo muito mais ao "juízo", do que ao "olho". O que implica dizer que o pintor ou escultor na concepção de suas obras deveria ter em mente a norma óptica de levar em consideração o ângulo de visão em que elas deveriam ser contempladas, de modo a sêlo com nitidez segundo a distância em que estivessem. ${ }^{44}$

Segundo, a não completude ou imperfeição das obras se daria devido ao que Vasari constatou como "furor artístico" do artífice, isto é, determinado "ímpeto ou impulso criativo", que se traduziria em expressar todo o conceito, ou forma idealizada em seu interior numa gestualidade súbita e única. O trabalho assim resultante seria imperfeito, porém, dotado de uma vivacidade natural, diferente de uma obra que fosse concluída nos mínimos detalhes com extremo labor e diligência, revertendo-se numa imagem artificiosa. ${ }^{45}$

\footnotetext{
${ }^{43}$ BAROCCHI, Paola. Finito e non-finito nella critica vasariana, in Arte Antica e Moderna, V. I, 1958, p. 221: "Quando il Vasari scriveva la Torrentiniana i casi più clamorosi di 'imperfezione' - le ultime 'Pietà' michelangiolesche - non gli ponevano ancora l'urgente, assoluto problema della loro giustificazione estetica. Egli si occupava della 'imperfezione' sopratutto in funzione strumentale, come di una tecnica esecutiva, allorché, nel trattato 'Della Sculptura', consigliava di dipingere e scolpire 'più con il giudizio che con la mano', specie le opere da coloccare a distanza. Nella direzione dell'Alberti e di Leonardo, che consideravano l'uno 'il diminuire delle quantità visive', l'altro, 'il variare dei colori secondo la luce', il Vasari consiglia agli artefici di dominare i dati ambientali com un 'giudizio' che temperi la 'diligenza'.

${ }^{44}$ Idem, ibidem: "Debbono le figure, così di rilievo come dipinte, esser condotte più con il giudizio che con la mano, avendo a stare in altezza dove sia una grande distanza, perché la diligenzia, dell'ultimo finimento non si vede da lontano, ma si conosce bene la bella forma delle braccia e delle gambe, et il buon giudizio nelle falde de' panni com poche pieghe: perché nella semplicità del poço si mostra l'acutezza dello ingegno [...]". Cf. not 4 correspondente: "I passi del Vasari sono tratti, per la Torrentiniana, dalla ristampa curata da C. Ricci, Roma, 1927, e per la Giuntina dalla clássica edizione di G. Milanesi, alle quali facciamo riferimento con la semplice indicazione del nome del curatore, seguito dal volume e dalla pagina".

${ }^{45}$ Idem, ibidem, p. 222: "Perché il furore dell'arte in un subito esprime il concetto dell'animo; il che non può fare la diligenza e la fatica nelle cose pulite". "Pare ancho che nelle bozze molte volte, nascendo in un subito
} 
Pino e Dolce condenam igualmente a extrema diligência do pintor, cônscios de que tal atitude poderia inibir a naturalidade da obra. ${ }^{\mathbf{4 6}}$

Contudo, a distinção entre tantas maneiras de "imperfeições" próprias a diferentes artífices, fez com que Vasari, ainda na edição das Vite de 1550, refutasse esta proposição do cânone do juízo do olho enquanto resposta totalizante dos vários exemplos e passasse a analisar casos e indivíduos em particular, cujo resultado mais rico e variado seria percebido na edição de $1568 .^{47}$

Barocchi observa que a idéia da dicotomia entre o "furor" e a "diligência" desenvolvida em Vasari deveu-se também ao influxo literário da contenda sobre a língua vulgar exercido sobre o humanista devido à sua convivência com Benedetto Varchi e Vincenzio Borghini. Nesta querela (como já levemente mencionado no capítulo III), antepunham-se a rudeza e impetuosidade de um Dante, contra o polido e diligente Petrarca, culto em retórica, poética e letras; ou, então, associando-se o furor poético platônico ligado à inventio, contra a dispositio-elocutio, racionalista da Poética de Aristóteles, defendida pela falta de moderação de Pietro Aretino. ${ }^{48}$

Em Michelangelo, a problemática do non-finito constituía um fenômeno excessivo, dado que pouquíssimas obras escultóricas tardias começadas por ele haviam chegado a um termo. Além daquelas que ele destruía por não atingirem o fim que ele havia proposto e não o satisfazerem plenamente. A razão para este comportamento deveu-se, de acordo com Vasari, ao fato de que o "juízo de Michelangelo fosse tão superior, que ele jamais se

dal furore dall'arte, si esprima il suo [dell'opera] concetto in pochi colpi, e che per contrario lo stento e la troppa diligenza alcuna fiata toglie la forza ed il sapere a coloro che non sanno mai levare le mani dall'opera che fanno".

${ }^{46}$ PINO, Paolo, op. cit., p. 18: "L'ispeditione riesce in tutte le cose, mà la prestezza nell'huomo è disposition natural, et è quasi imperfettione. In ciò non merta il maestro lode per non esser tal cosa acquistata da lui, ma donatagli dalla natura. Et poi non si giudica nell'arte nostra la quantità del tempo ispeso nell'opera, ma sola la perfettione d'essa opera per la qual si conosce il maestro eccellente dal goffo. Vero è ch'ambi gli estremi sono biasimevole e a questo proposito si dice, ch'Apelle biasimava a sè stesso, perché era troppo diligente, ne mai finiva di ricercare e perficere l'opere sue, la qual cosa è molto all'intelletto nociva". Cf. Anexo, p. 57-58.

DOLCE, Lodovico, op. cit., p. 185: "Bisogna sopra tutto fuggire la troppa diligenza, che in tutte le cose nuoce". Cf. Anexo, p. 131.

${ }^{47}$ BAROCCHI, Paola, op. cit., p. 223.

${ }^{48}$ Idem, ibidem, p. 223: "E l'approfonfimento si giova finanche di un parallelo letterario, che è probabilmente il frutto della consuetudine di Giorgio col Varchi e col Borghini, difensori del rude e impetuoso Alighieri contro le censure del distillato e levigato petrarchismo e cultori illustri di rettorica, di poetica, di critica letteraria. Dalla loro conversazione egli deve aver orecchiato i motivi dell'estetica umanistica e rinascimentale, tra cui quelli platonici del furore poético, e del prevalere dell'inventio sulla dispositio e sull'elocutio, variamente commisti, se non cedenti, al razionalismo della 'Poetica' di Aristotile e particolarmente vivace nella scapigliatura Fiorentino-veneziana, sovrastata da Pietro Aretino". 
contentava com o que fazia". 49 À tese desse não contentamento de Michelangelo (oriunda de Ascanio Condivi), Vasari alia uma profunda auto-consciência dos próprios limites do artífice e no infrutífero empenho de superá-los. Ou o non-finito corresponderia ainda a uma manifestação da liberdade criativa, uma licença no sentido de contrapor a perfeição do classicismo renascentista, numa espécie de reação anti-canônica. ${ }^{\mathbf{5 0}}$

No que concerne a Ticiano, Vasari aponta-o como modelo exemplar da hipótese sobre do "furor artístico", pois segundo Barocchi:

"Poucos são aqueles que ao executar sua obra permanecem coerentes ao "furor" inicial e a concluem sem gelar as veias e perder-se no particular, porque negativo será o "furor" se uma inadequada "energia" o impedir de cair numa improvisação de prática fácil. Valha como aplicação modelar de tal conceito, o agudíssimo juízo de Vasari sobre o estilo furioso e estudioso ao mesmo tempo do tardio Ticiano. ${ }^{\mathbf{5 1}}$

E Vasari, com relação a Ticiano expressa:

"É verdade que a maneira com que executou as últimas obras é demasiado diferente do seu fazer quando era jovem; as primeiras foram conduzidas com certa fineza e diligência inacreditáveis, a fim de serem contempladas de perto e de longe; porém estas últimas foram realizadas por meio de golpes, com arremessos grossos de tintas formando manchas, a ponto de que, perto não possam ser vistas, mas de longe revelam-se com

\footnotetext{
${ }^{49}$ Idem, ibidem, p. 224: "Lavorava Michelagnolo quase ogni giorno per suo passatempo intorno a quella Pietà ... con le quattro figure; la quale egli spezzò in questo tempo per queste cagioni: perché quel sasso aveva molti smerigli ed era duro e faceva spesso fuoco nello scarpello, o fusse pure che il giudizio di quello uomo fussi tanto grande, che non si contentava mai di cosa che e' facessi [...]".

${ }^{50}$ Idem, ibidem, p. 225: "Evidentemente insoddisfatto di uma causa accidentale (il vizio del sasso) il Vasari dapprima aderisce, come altrove, allá tesi condiviana della incontentabilità dell'artista, ma subito dopo la determina come consapevolezza di "errore" [...]. "All 'errore' del Buonarroti il Vasari deve cercare una reagione ben diversa e finisce col trovarla nella consapevolezza dei propri limiti soggettivi e nell'insone impegno di superarli. Il non-finito assurge per questa via a manifestazione della libertà creativa, della "licenza" di Michelangelo; ed è Michelangelo, nella Giuntina, l'artista del non-finito: non già per temperamento, dacché egli è anche maestro del finito, ma in quanto campione - all'uno e all'altro titolo, questa volta - dell'anticanonismo cinquecentesco [...]".

${ }^{51}$ Idem, ibidem, p. 224.
} 
perfeição. Essa é a razão devido a qual muitos, ao pretenderem imitar-lhe a maneira, e querendo se mostrar práticos, têm feito pinturas as mais desgraciosas. E isso acontece porque, se a muitos parece que Ticiano as tenha feito sem grande labor, enganam-se, pois não é verdade, porque sabese que tais obras são refeitas e que ele se volta a elas com as cores inúmeras vezes, a ponto de ser perceptível quanta fadiga despenderam. E essa maneira realizada é muitíssimo judiciosa, bela e estupenda, porque torna viva as pinturas, pois são realizadas com grande arte, e com muito labor oculto". 52

Se o non-finito em Michelangelo pode-se revelar enquanto uma irrealização ou conflituosa inadequação dos meios plásticos à genialidade de sua potente necessidade interior de expressão, em Ticiano, a maneira "imperfeita", disseminada em manchas luminosas de cor, poderia, por sua vez, representar em oposição a Michelangelo um completo encontro da maturidade extrema com a expressão dos meios plásticos, num sentido de exprimir em toda sua plenitude o conceito e intenção do pintor.

Pela exposição acima observamos que na metade do século XVI não se prefigura ainda um primado da cor sobre o desenho. O que se depreende pelo teor dos escritos é uma reivindicação pelo valor da expressão cromática na pintura. Nesta disputa encontram-se os fundamentos preliminares de uma doutrina do colorido, que adquirirá contorno preciso somente no século XVII com os acadêmicos franceses, havendo seu ponto de origem nestes mesmos tratados.

Os tratados de Pino e Dolce apresentam-se como uma tímida insurgência dos venezianos aos pressupostos dos teóricos tosco-romanos, exaltados de modo eminente pelas obras de Alberti, Leonardo e Vasari, e por meio dos quais o desenho eleva-se a componente preponderante das artes figurativas, em razão de seu vínculo com a razão e o intelecto. Nesta resposta veneta, em especial aos florentinos, subleva-se contra o papel coadjuvante

\footnotetext{
${ }^{52}$ Idem, ibidem, p. 224: "Ma è ben vero che il modo di fare che tenne in queste ultime [opere] è assai differente da fare suo da giovane; con ciò sia che le prime son condotte con una certa finezza e diligenza incredibile e da essere vedute da presso e da lontano, e queste ultime condotte di colpi, tirate via di grosso e con macchie, di maniera che da presso non si possono vedere e di lontano appariscono perfette. E questo modo è stato cagione che molti, volendo in ciò immitare e mostrare di fare il pratico, hanno fatto di goffe pitture. $\mathrm{E}$ ciò adiviene perchè, se bene a molti pare che elle siano fatte senza fatica, non è così il vero, e s'ingannano, perché si conosce che sono rifatte e che si è ritornato loro addosso con i colori tante volte, che la fatica vi si vede. E questo modo sì fatto è giudizioso, bello e stupendo, perché fa parere vive le pitture e fatte con grande arte, nascondendo le fatiche".
} 
da cor na arte em seu aspecto mecânico. A defesa argumenta não ser suficiente lançar cores belas na tela, pois, à grandiosidade da pintura são requeridas habilidade manual, visual e intelectual e muito mais, a maestria do pintor no transformar cores em colorido. Uma vez que somente a infinita dimensão do colorido permite traduzir o natural em expressões peculiares de tonalidades de pele, texturas diversas, relevo, claros e escuros, graciosidade, conferindo tão grande vida à pintura, que o desenho com sua toda potência criadora não consegue alcançar. Mas se a cor de Ticiano defronta-se com o desenho de Michelangelo, a expressão plástica do non-finito aproxima os dois mestres, cada um a seu modo, porém iguais na maestria da arte. 


\section{Considerações Finais}

A partir dos argumentos desenvolvidos nesta pesquisa, vimos que a concepção dos dois tratados deveu-se a fins específicos e divergentes. Enquanto o Dialogo di Pittura, de Paolo Pino (1548), foi a resposta de um artífice veneziano ao tratado Della Pittura, do florentino Leon Battista Alberti, traduzido por Lodovico Domenichi e publicado em Veneza em 1547, o Dialogo della Pittura intitolato L'Aretino, de Lodovico Dolce (1557), por sua vez, foi uma reação à obra de Giorgio Vasari, as Vite, cuja primeira edição data de 1550.

A obra de Dolce tinha por objetivo defender a importância da pintura veneziana no contexto artístico italiano destacando a figura de Ticiano, em contraposição aos argumentos de Vasari, que propunham atestar o caráter de divindade a Michelangelo. Segundo a hipótese de Mark Roskill, a idealização de uma réplica a Vasari poderia ter surgido no círculo humanista de Aretino. Embora não pertencesse a esse círculo, Dolce, por ter sido responsável pela edição da segunda parte de suas cartas, e pelas correspondências trocadas com o escritor, tomou a si o encargo de escrever tal libelo, e o intitulou de tal forma em homenagem a Aretino, que morrera um ano antes da publicação do tratado.

No decorrer deste trabalho procuramos reunir argumentos para responder questões que consideramos de extrema relevância para a compreensão da produção artística do século XVI. A primeira dessas questões diz respeito à possibilidade de se delinear uma teoria artística peculiar à pintura veneziana na primeira metade do século XVI. Com efeito, foi possível encontrar vestígios significativos, já que não é possível falar-se ainda de uma teoria da arte veneziana totalmente consolidada neste período. Pelo contrário, como foi visto, o que há é o esboço de fundamentos que começam a se edificar através dos tratados de Pino e Dolce.

Outra pergunta desta pesquisa buscava saber se haveria ou não dissonâncias entre a teoria da arte veneziana e a teoria desenvolvida na região tosco-romana. As divergências puderam ser localizadas no processo de investigação artística de ambas as regiões. Os artífices tosco-romanos, mais preocupados com uma teoria do conhecimento e na ânsia de provar que a pintura era uma arte do intelecto e não mecânica, vincularam-na a preceitos 
matemático-científicos. Já os artífices venezianos fundamentaram suas pesquisas na relação da pintura com normas literárias.

E quais seriam os conceitos filosóficos inerentes a essas duas teorias? Ambas utilizam categorias filosóficas platônicas e aristotélicas, as quais são veiculadas por todas as regiões da Itália, como a noção de imitação e a questão da Idea. Mas, em alguns aspectos, como por exemplo, os preceitos referentes à mimesis, e o ideal de beleza, os dois tratados demonstram que a teoria veneziana sofreu maior influência de Aristóteles.

Observamos também que os dois tratados apresentam uma identidade quanto à discussão de algumas temáticas, e pela veemente defesa da expressão cromática veneziana frente à linearidade do desenho tosco-romano. Se a princípio Pino e Dolce não pretendiam criar uma teoria artística veneziana, acabaram, contudo, por assentar as bases para sua edificação nos séculos posteriores a partir da convicção da relevância da cor frente ao desenho na pintura, devendo ser equiparada em valor a ele, ao invés de ser-lhe subjugada. As premissas que formam tais bases encontram-se: a) no preceito de imitação aristotélico da natureza; b) na prescrição de normas retóricas para a pintura, de maneira mais exacerbada do que haviam feito os florentinos; c) na defesa da doutrina do ut pictura poesis; d) na constatação das possibilidades específicas de expressão do colorido.

Cumpre assinalar que, se que se houve uma crítica dos teóricos venezianos pelo extremo racionalismo da teoria artística tosco-romana por seu apego às ciências, eles não deixaram de criar também premissas bastante racionais, ao circunscrever toda a concepção pictórica a regras tão rígidas quanto o foram as da Arte Retórica.

No entanto, acreditamos poder afirmar que este começo de uma teoria veneziana não teria sequer sido delineado se não fosse o tratado de Pino, pois os próximos que lhe seguiram, sejam o de Lodovico Dolce, ou o Disegno, de Anton Francesco Doni (1549) e a Della Nobilissima Pittura, de Michelangelo Biondo (1549), talvez não tivessem sido concretizados sem aquele primeiro, pois todos, a seu modo, rediscutiram as mesmas temáticas propostas em seu Dialogo, embora com argumentos distintos. 


\section{Referências Bibliográficas}

\section{Fontes primárias}

PINO, Paolo. Dialogo di Pittura. Edição crítica aos cuidados de Ettore Camesasca, Milano: Rizzoli Editore, 1954.

PINO, Paolo. Dialogo di Pittura. In BAROCCHI, Paola (a cura di). Trattati d'Arte del Cinquecento - Fra Manierismo e Controriforma, vol. primo. Aos cuidados de Paola Barocchi. Bari: Gius. Laterza e Figli, 1960.

PINO, Paolo. Dialogo di Pittura. Edição crítica aos cuidados de Susanna Falabella. Roma: Lithos Editrice, 2000.

PALLUCCHINI, Rodolfo e Anna. Introdução e notas ao Dialogo di Pittura, de Paolo Pino. Venezia: Edizioni Daria Guarnati, 1946.

DOLCE, Lodovico. Dialogo Della Pittura, in Barocchi, Paola (Org.) Trattati D'Arte del Cinquecento - Fra Manierismo e Controriforma. Vol. I, Bari: Gius. Laterza e Figli, 1960.

DOLCE, Lodovico. Dialogue de la peinture intitule L'Aretin. Apresentação e notas, Lauriane Fallay d'Este. Tradução Nathalie Bauer. Paris: Klincksieck, 1996.

ROSKILL, Mark W. Roskill. Dolce's Aretino and Venetian Art Theory of the Cinquecento. Toronto: University of Toronto Press, 2000.

\section{Fontes secundárias:}

ALBERTI, Leon Battista. Della Pittura (Edizione critica a cura di Luigi Mallè). Firenze: G.C. Sansoni Editore, 1950.

ARISTÓTELES. A Poética. Biblioteca dos Séculos. Porto Alegre: Globo, 1966.

BAROCCHI, Paola. (Org.) Trattati d'Arte del Cinquecento - Fra Manierismo e Controriforma. Bari: Gius. Laterza e Figli, v.I, 1960, v. II, 1961, v. III, 1962.

BAROCCHI, Paola. (Org.). Scritti d'Arte del Cinquecento. Milano-Napoli: Riccardo Ricciardi Editore, 1970.

BERNABEI, Franco. "Tiziano e Ludovico Dolce". In: PALLUCCHINI, Rodolfo (Org.) Tiziano e il manierismo europeo. Florença: L.S. Olschki, 1978.

BLUNT, Anthony. Artistic Theory in Italy (1450-1600). London: Oxford University Press, 1985.

CASSIRER, Ernst. Eidos et Eidolon. Le Problème Du Beau et de l'art dans les Dialogues de Platon in Écrits sur l'Art, traduit de l'allemand par Christian Berber - Oeuvres de Cassirer (XII) éditées en français, en collaboration avec la Internationale Ernst CassirerGesellschaft sous la direction de Fabien Capeillères et Heinz Wismann. New Haven, Connecticut: Yale University Press; Paris: Les Éditions du Cerf, 1995.

. Eidos ed Eidolon - Il problema del bello e dell'arte nei dialoghi di

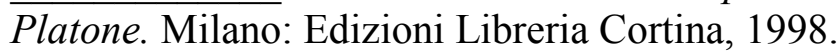

CASTIGLIONE, Baldassare. O Cortesão. São Paulo: Martins Fontes, 1997.

CICERO, De Oratore. Texto latino com tradução para o inglês de E. W. Sutton. Cambridge: Harvard University Press, 1948.

CÍCERO, Marco Túlio. De Optimo Genere Oratorum. Tradução Luiz Marques. [mimeo]

COLlingWOOD, R.G. Ciência e Filosofia. Lisboa: Editorial Presença, 1981. 
DACOS, Nicole. L'esperienza dell'antico, dell'Europa, della religiosità - Arte Italiana e Arte Antiga in Storia dell Arte Italiana. Torino: Giulio Einaudi Editore, 1979.

DELL'ACQUA, Gian Alberto. "L'Ultimo Tiziano” In: PALLUCCHINI, Rodolfo (Org.) Tiziano e il manierismo europeo. Florença: L.S. Olschki, 1978.

EQUICOLA, Mario. Che cosa è bellezza in BAROCCHI, Paola (Org.) Scritti d'Arte del Cinquecento. Milano-Napoli: Riccardo Ricciardi Editore, 1970.

GRASSI, Luigi. Teorici e Storia Della Critica d'Arte. Primeira Parte. Roma: Multigrafica Editrice, 1970.

KLEIN, Robert. A Forma e o Inteligível - Escritos sobre o Renascimento e a Arte Moderna. São Paulo: Edusp, 1998.

KLEIN, Robert and ZERNER, Henri. Italian Art 1500-1600 - Sources and Documents in the History of Art Series. New Jersey: Prentice-Hall, Inc., 1966.

LEONARDO, da Vinci. Trattato della Pittura. Roma: Grandi Tascabili Economici Newton, 1996.

NIFO, Agostino. De Pulchro Grazia. in BAROCCHI, Paola (Org.) Scritti d'Arte del Cinquecento. Milano-Napoli: Riccardo Ricciardi Editore, 1970.

PALLUCCHINI, Rodolfo. La Pittura Veneziana del Cinquecento in Storia della Pittura Italiana. Istituto Geografico de Agostini Novara. [s/d., s/1.]

PANOFSKY, Erwin. Idea. Contribuição à história do conceito da antiga teoria da arte. São Paulo: Martins Fontes, 1994.

Significado nas Artes Visuais. São Paulo: Perspectiva, 1979.

QUINTILIANO, M. Fábio. Instituições Oratórias. São Paulo: Edições Cultura, 1944, 2 vols.

QUINTILIAN. The Institutio Oratoria. With an english translation by H. E. Butler. Cambridge Massachusetts: Harvard University Press, 1998.

ROUCHETTE, Jean. La Renaissance que nous a léguée Vasari. Paris: Les belles lettres, 1959.

SCHLOSSER, Julius von. La Letteratura Artistica - Manuale delle Fonti della Storia dell'Arte Moderna. Firenze: "La Nuova Italia" Editrice, 1956.

SABBATINO, Pasquale. La Bellezza di Elena - L'imitazione nella letteratura e nelle arti figurative del Rinascimento. Roma: Leo S. Olschki Editore, 1997.

STEER, John. Venetian Painting. London: Thames and Hudson. 1995.

VARCHI, Benedetto. Libro della Beltà e Grazia in BAROCCHI, Paola (Org.) Scritti d'Arte del Cinquecento. Milano-Napoli: Riccardo Ricciardi Editore, 1970.

VENTURI, Lionello. Storia della Critica d'Arte. Turim: Giulio Einaudi Editore, 1964.

VICKERS, Brian. In Defense of Rhetoric. Oxford: Clarendon Press, 2002.

\section{Artigos em periódicos}

BAROCCHI, Paola. "Finito e non-finito nella critica vasariana". In: Arte Antica $e$ Moderna, V. I, (1958).

BATTISTI, Eugenio. "Il concetto d'imitazione nel Cinquecento dai Veneziani a Caravaggio". In: Commentari, VII, 1956, pp. 250 a 253.

GILBERT, Creighton. "Antique Frameworks for Renaissance Art Theory: Alberti and Pino”. In: Marsyas, III, 1943-1945. 
GRASSI, Luigi. "I concetti di schizzo, abbozzo, macchia, "non finito" e la costruzione dell'opera d'arte". In: Studi in onore di P. Silva, Firenze, 1957, p. 100.

GOLDSTEIN, Carl. "Rhetoric and Art History in the Italian Renaissance and Baroque". In: The Art Bulletin, V LXXIII, n. 4, 1991.

KNOLL, Victor. "Sobre a Questão da Mimesis". In: Discurso. FFLCH - USP, v. 27, 1996.

RENSSELAER W. Lee. "Ut pictura poesis. The humanist theory of painting". In: Art Bulletin, XXII, 1940.

\section{Obras Consultadas}

ALVES, Luiz Roberto. Diálogos de Amor. Humanismo e Exílio em Jehuda Abravanel. São Paulo: Edusp/Fapesp/Nova Alexandria, 1997.

ARISTÓTELES. De Anima. Apresentação, trad. e notas de Maria Cecília Gomes dos Reis. São Paulo: Editora 34, 2006.

ARISTOTELE. Retorica. Introduzione di Franco Montanari. Testo critico, traduzione e note a cura di Marco Dorati. Milano: Arnoldo Mondadori Editore, 1996.

ARISTÓteles, HORÁCIO, LONGINO. A Poética Clássica. São Paulo: Cultrix, 1997. BALDINI, Massimo (org.). Leonardo da Vinci, Aforismi, Novelle e Profezie. Roma: Newton Compton Editori, 1993.

BEMBO, Pietro. Prose della Volgar Lingua. Torino: Unione Tipografico-Editrice Torinese, 1931.

BURCKHARDT, Jacob. A Cultura do Renascimento na Itália. São Paulo: Companhia das Letras, 1991.

CENNINI, Cennino. Il Libro dell'Arte (Edizione riveduta e corretta sui codici per cura di Renzo Simi). Lanciano R. Carabba Editore.

DANIELlO, Bernardino. Della Poética. In WEINBERG, Bernard. Trattati di Poetica e Retorica del Cinquecento. Roma: Laterza Editore, 1970-1974. (site: www.bibliotecaitaliana.it).

GARIN, Eugenio. O Homem Renascentista. Lisboa: Editorial Presença, 1991.

L'Umanesimo Italiano - Filosofia e vita civile nel Rinascimento. Roma-

Bari, Giuseppe Laterza \& Figli, 1984.

GRASSI, Luigi e PEPE, Mario. Dizionario dei Termini Artistici. Tea Editore.

LAUSBERG, Heinrich. Elementos de Retórica Literária. Lisboa: Fundação Calouste Gulbenkian, 1993.

LICHTENSTEIN, Jacqueline. A pintura. Textos Essenciais. São Paulo, Editora 34, 2006.

NIFO, Agostino. De Pulchro et amore; De Pulchro Liber; Du Beau et de L'Amour; Le Livre du Beau. Édition critique, traduction, introduction et notes par Laurence Boulègue. Paris: Société d'édition Les Belles Lettres, 2003.

PETRARCA. Triunfos. São Paulo: Hedra, 2006.

SHEARMAN, John. O Maneirismo. São Paulo: Cultrix/Edusp, 1978.

VASARI, Giorgio. Le vite dei più eccellenti pittori, scultori e architetti. Roma: Grandi Tascabili Economici Newton, 1991. 